UNIVERSIDADE DE SÃO PAULO

FACULDADE DE ECONOMIA, ADMINISTRAÇÃO E CONTABILIDADE

DEPARTAMENTO DE ADMINISTRAÇÃO

PROGRAMA DE PÓS-GRADUAÇÃO EM ADMINISTRAÇÃO

DA COOPERAÇÃO À TERRA: EXPERIÊNCIAS ASSOCIATIVAS EM PIRITUBA II

Yasser Hassan Saleh

Orientadora: Maria Sylvia Macchione Saes

São Paulo 
Prof. Dr. Marco Antonio Zago

Reitor da Universidade de São Paulo

Prof. Dr. Adalberto Américo Fischmann

Diretor da Faculdade de Economia, Administração e Contabilidade

Prof. Dr. Roberto Sbragia

Chefe do Departamento de Administração

Prof. Dr. Moacir de Miranda Oliveira Júnior Coordenador do Programa de Pós-Graduação em Administração 
YASSER HASSAN SALEH

\title{
DA COOPERAÇÃO À TERRA: EXPERIÊNCIAS ASSOCIATIVAS EM PIRITUBA II
}

\author{
Dissertação apresentada ao Programa de Pós- \\ Graduação em Administração da Faculdade de \\ Economia Administração e Contabilidade da \\ Universidade de São Paulo para obtenção do \\ título de Mestre em Ciências
}

Orientadora: Prof ${ }^{\mathrm{a}}$. Dra ${ }^{\mathrm{a}}$. Maria Sylvia Macchione Saes

\section{Versão Corrigida}

(versão original disponível na Biblioteca da Faculdade de Economia, Administração e Contabilidade)

São Paulo 


\section{FICHA CATALOGRÁFICA}

Elaborada pela Seção de Processamento Técnico do SBD/FEA/USP

Saleh, Yasser Hassan

Da cooperação à Terra: experiências associativas em Pirituba II/Yasser Hassan Saleh. - São Paulo, 2017.

$269 \mathrm{p}$.

Dissertação (Mestrado) - Universidade de São Paulo, 2017.

Orientadora: Maria Sylvia Macchione Saes.

1. Cooperativas 2. Reforma agrária 3. Economia institucional 4. Movimentos sociais I. Universidade de São Paulo. Faculdade de Economia, Administração e Contabilidade. II. Título. 


\section{DEDICATÓRIA}

Dedicado ao mártir da causa patriótica árabe e herói do povo sírio, o coronel do Exército Árabe Sírio, Mustafa Abdel-Karim Shaddoud, caído em 2013. Que Deus tenha piedade de sua alma. 


\section{AGRADECIMENTOS}

Inicialmente, agradeço ao CNPq e à FAPESP pelo apoio ao presente estudo.

Agradecer é algo muito difícil e que nem sempre se consegue aprender a fazê-lo devidamente numa curta vida. Esquecerei fatalmente agradecimentos, da forma merecida a todos, assim como não sei se poderei retribuir a ajuda que me foi prestada por todos.

Agradeço à minha mãe, Maria Marlene Mohamad Saleh, ao meu pai, Hassan Ibrahim Saleh e ainda à minha irmã, Nila, pela paciência, pela força, pelo carinho e pelos perdões que me concederam nesse período - assim como aos dois anjos que estão no céu e que me acompanharam em todo esse percurso, como se o primeiro dos sete céus descesse à terra diante de mim em todos esses momentos.

Nunca imaginei que esta pesquisa me fizesse entender tanto minha origem e minha família. Esse apoio começou na província síria de Tartus. Agradeço ao Professor AbdelKarim Salloum, filho da cidade de Safita, que na escola rural de meu pai, o ensinou o valor do saber, do conhecimento e das dificuldades decorrentes pela falta deles em sua vida.

Agradeço à minha família e a todas as gerações que me precederam. Espero honrá-los e quem sabe um dia eu retribua ao Líbano essa benção.

Agradeço à Professora Maria Sylvia Macchione Saes por ter aceitado me orientar diante de tantas dificuldades -foi muito mais do que uma orientadora. Muito obrigado!

Não poderia esquecer ao grande amigo, irmão e filho da PUC-SP, um anjo, Leandro Simões Pongeluppe, por me encorajar a entrar nessa área de estudos e não desistir nunca.

Agradeço também pelo carinho, e por ser minha companheira em momentos tão difíceis, Dione Pozzebon. Espero que a partir desta pesquisa eu possa valorizar a arte como ela o faz. ão poderei me esquecer de mencionar os professores Bernardete Marinho, Nuno Fouto, Carla Ramos e, em especial, Flávio Saes, pela especial paciência em dar atenção a mim e às minhas ideias, no mínimo, raras.

Agora, esquecerei, outros, claro, e espero não aborrecê-los por não terem sido incluídos. Mas não os colegas do CORS que me apoiaram em diversos momentos, e amigos Andrés D'Agostino Eugui, George Samir Abdul-Hak, Manar Machrik, Guilherme Bittar e Cris Celestino, Marcio Tadashi Abe, David Magalhães e Laura Mattar, Elizabete Simões, Gabriel Hilário, Luc Wüst, Anders Friedriksson, Gaby Friess Kirsch, Maria Estela Veronezi, Julia Marchevsky, Roberta Lima e a muitos outros, inclusive minha revisora Lucy Petroucic.

Agradeço ao leitor o acaso de me perdoar pelos erros cometidos no texto. Eles são de total responsabilidade minha. Reconheço não ter conseguido facilitar a leitura como deveria. 


\section{RESUMO}

SALEH, Y. H. Da Cooperação à terra: experiências associativas em Pirituba II. 2017. 262 f. Dissertação (Mestrado)— Faculdade de Economia, Administração e Contabilidade, Universidade de São Paulo, São Paulo, 2017.

A caracterização social de cooperativas e organizações similares inspirou estudos científicos e ações sociais no Brasil e no mundo. A abordagem do tema inicia-se, pela economia institucional, com enfoque na concepção de estruturas de governança como nível analítico baseado na Economia de Custos de Transação (ECT). Na agricultura, as experiências cooperativas objetivaram a inserção ou manutenção de agentes econômicos no mercado. Por outro lado, no caso da questão da reforma agrária as ações governamentais tiveram a finalidade de promover a organização da produção. O papel das mobilizações sociais em defesa da reforma agrária é constatado como proponente de formas de inserção alternativas, a exemplo ao modelo de cooperativas do Movimento dos Trabalhadores Rurais Sem-Terra (MST). O objetivo deste trabalho é compreender como as relações de poder da mobilização de grupos, como os movimentos sociais, influenciam a configuração de organizações cooperativas. Para atingi-lo toma-se o caso do assentamento Pirituba II, palco de diversas experiências que continham os elementos da mobilização política, da intervenção agrária do governo e de propostas de cooperação por diferentes atores. Os resultados demonstram que a lógica da ação coletiva intencionada pelos assentados corresponde a uma dinâmica familiar. Tomando as intervenções no sentido da indução da cooperação, observaram-se problemas da sua realização diante desta dinâmica.

Palavras-chave: Cooperativas. Reforma agrária. Economia institucional. Movimentos sociais. 


\begin{abstract}
Saleh, Y. H. (2017). From Cooperation to Land. Associative experiences in Pirituba II. p.

262. Master’s Thesis. Faculdade de Economia, Administração e Contabilidade, Universidade de São Paulo.

The social characteristics of co-operatives and similar organisations inspired scientific studies and social actions in Brazil and around the world. The initial approach on the theme by institutional economics focused on the conception of governance structures as an analytical level based on Transaction Costs Economics (TCE). In agriculture, the cooperative experiences aimed at the insertion or the maintenance of the economic agents in the market. However, in the case of agrarian reform the Governmental actions were in order to promote the organisation of the production. The role of social mobilisations in defence of agrarian reform was observed as a proponent of alternative insertion forms. In this study the cooperatives' model by the Landless Rural Workers' Movement (MST) is the object of this phenomenon. The objective of this work is to understand how power relations by groups' mobilisations, as social movements, influence the co-operative organisations' configuration. To that end, we used the case of the Pirituba II settlement, since it was the scene of several experiences containing the political mobilisation elements, the government's agrarian intervention and the motions of co-operation by different actors. The results show that the logic of collective action intended by the settlers corresponds to a family dynamics. In analysing the interventions aiming to induce co-operation, we observed that problems of its execution were due to this dynamics.
\end{abstract}

Keywords: Co-operatives. Agrarian reform. Institutional economics. Social movements. 


\section{LISTA DAS FIGURAS}

Figura 1 - Organograma básico de uma cooperativa ........................................................ 16

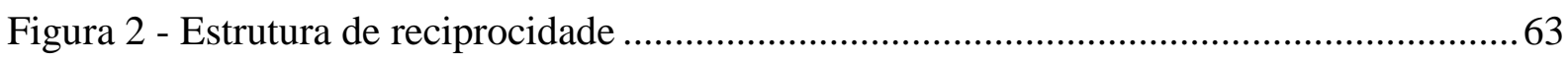

Figura 3 - Relação organizacional entre cooperativa e produtores assentados ....................... 29

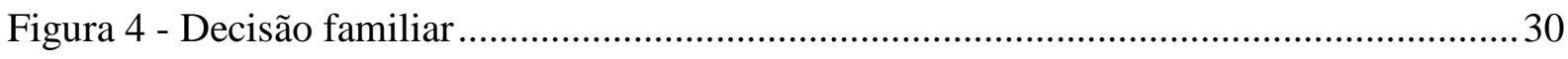

Figura 5 - Fluxo da cadeia de produção ........................................................................ 31

Figura 6 - Configuração da gestão na estrutura de governança............................................. 32

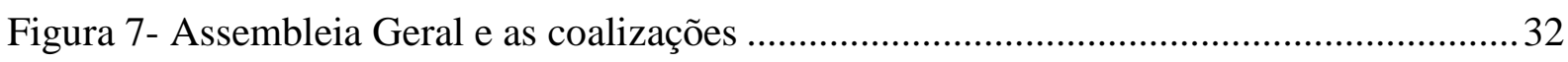

Figura 8 - Estrutura de reciprocidade binária simétrica ou assimétrica .................................. 33

Figura 9 - Estrutura de Reciprocidade Ternária - Unilateral ou Bilateral ................................ 33

Figura 10 - Estrutura de Reciprocidade em rede ................................................................ 33

Figura 11 - Estado de São Paulo com a localização dos municípios...................................... 106

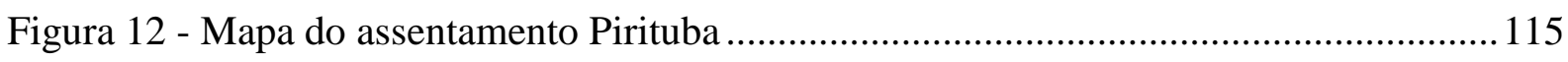

Figura 13 - Cartaz da campanha no ITESP contra os arrendamentos .................................. 155

Figura 14 - Estruturas de reciprocidade pela interação bilateral. Assentado-lojista, reciprocidade centralizada, lojistas no centro e assentados ao seu redor ............................. 163

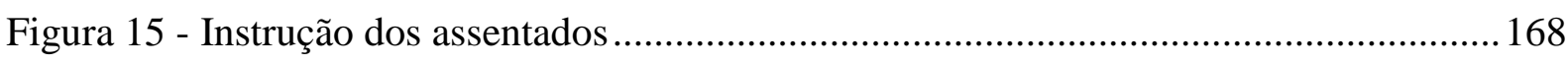

Figura 16 - Agente (tratorista) Principal (gestor da cooperativa) ....................................... 191

Figura 17 - Organograma da Copava como CPA ............................................................... 191

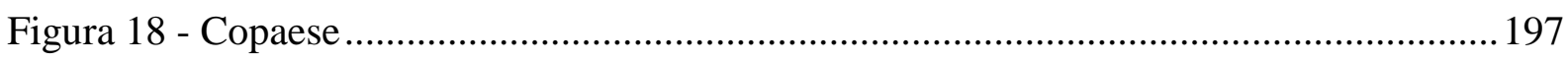

Figura 19 - Composição do Grupo Gestor da Coapri .............................................................200

Figura 20 - Galpão vazio com refrigerador de leite da Cofasp ...........................................2205

Figura 21 - Foto do quadro do Cristo Redentor com as mensagens ......................................211

Figura 22 - Movimentos dos Assentados Independentes ................................................215

Figura 23 - Tratores da primeira Associação do movimento ............................................... 221

Figura 24 - Mecanismo de barganha intermediando cooperados e mercado .........................227

Figura 25 - Ata das reuniões de mobilização do assentamento ............................................229 


\section{LISTA DOS QUADROS}

Quadro 1 - Características dos assentamentos no município de Itapeva.

Quadro 2 - Associações, cooperativas e grupos informais por área no assentamento Pirituba e respectiva forma de organização da produção 


\section{Sumário}

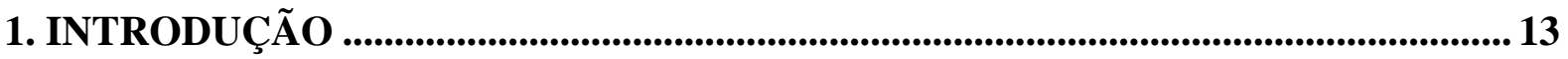

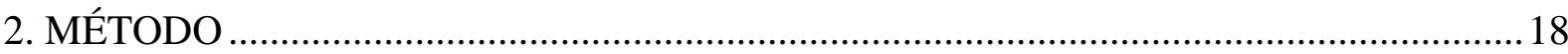

2.2.1 A Natureza da Pesquisa ............................................................................................................20

2.2.2 Das Especificidades do Campo Brasileiro e das Técnicas Empregadas para a Coleta dos Dados em Entrevistas ..................................................................................................26

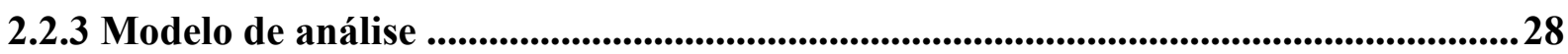

2.2.4 Procedimentos de coleta de dados.................................................................................34

2.2.5 Triangulação dos dados...................................................................................................38

3. A ABORDAGEM INSTITUCIONALISTA......................................................................... 40

3.1 A NOVA ECONOMIA INSTITUCIONAL ................................................................

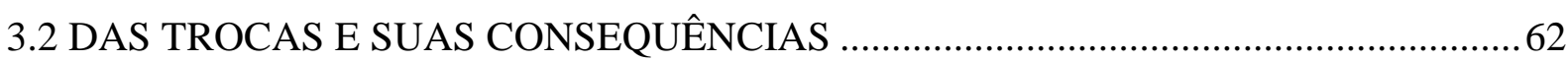

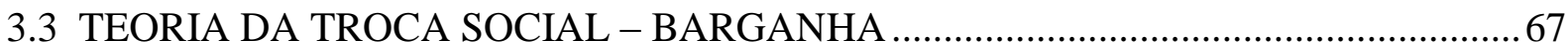

4. CHAYANOV E EMELIANOFF ENTRE A COOPERAÇÃO E A REVOLUÇÃO.. 71

4.1 ALEXANDER VASSILIEVICH CHAYANOV (1888-1937) ………………………....... 72

4.2 A TRANSMISSÃO DE SUA OBRA ATÉ OS DIAS ATUAIS ………………………...... 82

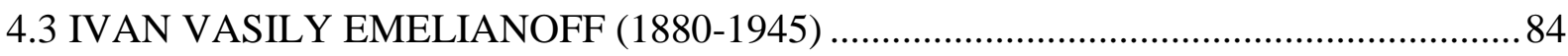

4.4 A TRADIÇÃO DE INSPIRAÇÃO EM EMELIANOFF ..................................................96

4.5 COMPLEMENTARIEDADE ENTRE CHAYANOV E EMELIANOFF.........................101

5. O ASSENTAMENTO PIRITUBA ....................................................................................... 103

5.1 UMA BREVE CONTEXTUALIZAÇÃO DA REFORMA AGRÁRIA NO BRASIL ...104

5.1.1 Antecedentes Do Assentamento ..........................................................................................105

5.1.2 O Governo Carvalho Pinto (1959-Fev/1963)..................................................................108

5.1.3 A Década de 1970 e os Governos Militares...................................................................109

5.1.4 A Abertura Política e o Governo Montoro (1983-1987) ..................................................110

5.2 EVOLUÇÃO DO ASSENTAMENTO - DAS ÁREAS 1 E 2 À ÁREA 6.........................113

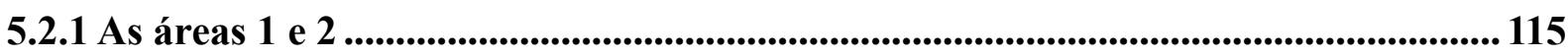

5.2.2 As agrovilas 3, 4, 5, e 6.............................................................................................. 117

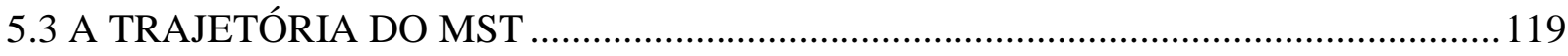

5.3.1 Formação (1979-1984).................................................................................................124

5.3.2 Crescimento (1984-1992) .......................................................................................................124

5.3.3 Auge (1992-2003) .....................................................................................................125 
5.3.4 Reestruturação (2003- Hoje)................................................................................................127

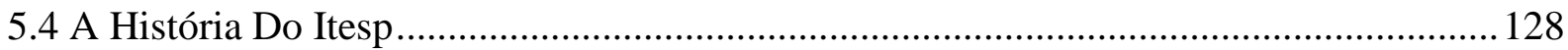

5.5.1 Das concepções de cooperação nos movimentos populares .....................................132

5.6 Breve Retorno aos Estudos da Cooperação e do Cooperativismo no Brasil .................... 137

5.7 A especificidade do movimento socioterritorial ............................................................ 144

5.7.1 Observações Preliminares sobre a Configuração das Interações no Espaço do

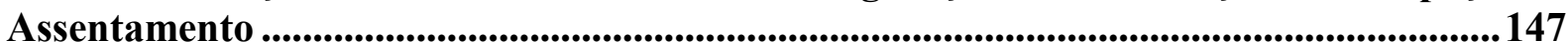

5.7.2 Propostas Econômicas quanto à mudança na relação de produção .......................149

5.8 Arranjos Produtivos Comerciais Atuais ........................................................................ 151

5.8.1 Parcerias (Reais Ou Arrendamentos Disfarçados) .............................................151

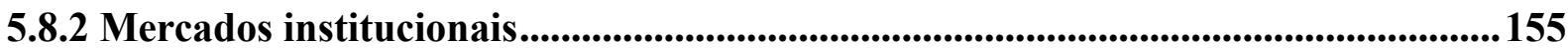

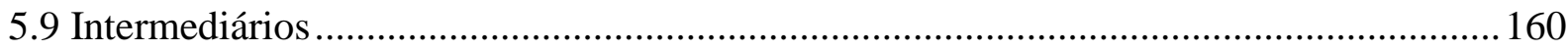

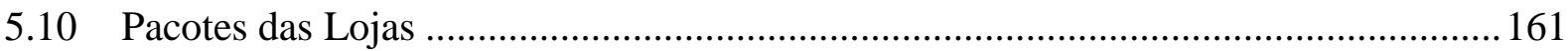

5.11 Dos Processos De Remuneração, ou de Distribuição Dos Resultados, dos Assentados a partir de Suas Respectivas Cooperativas............................................................... 166

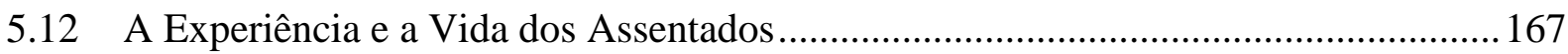

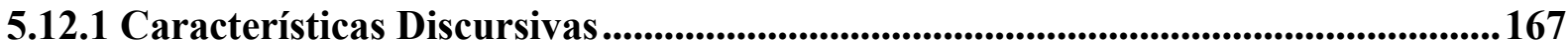

5.12.2 Da Instrução e da Formação Política.............................................................................167

5.12.3 O Termo Camponês ....................................................................................................169

5.12.4 Das Experiências Associativistas (Associações e Cooperativas) ................................171

5.13 O Padrão das Experiências Associativas e Seus Momentos ...................................... 173

5.14 A Proposta De Cooperação Coletiva: Dissidência Da Área 2 .................................. 178

5.15 O laboratório experimental e as propostas do MST (Clodomir dos Santos Morais) .. 184

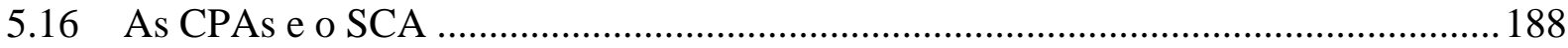

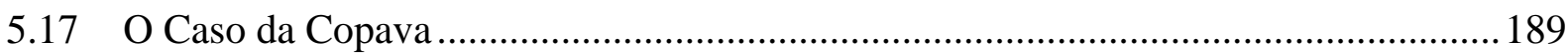

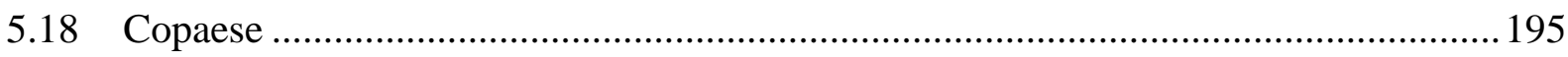

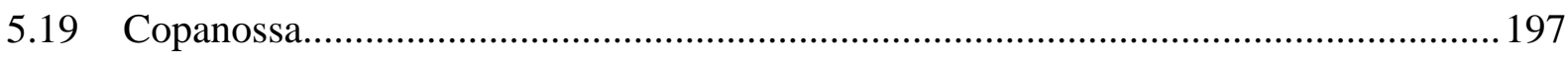

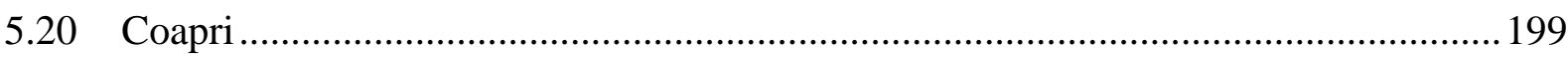

5.20.1 As Pessoas como ativos da organização:- o papel dos colaboradores .........203

5.20.2 A Emancipação Feminina ...................................................................................203

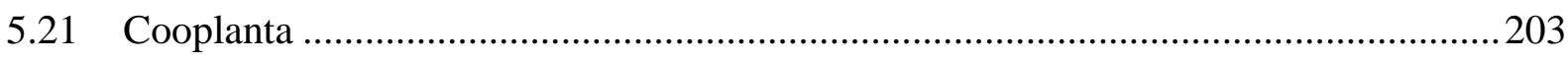

5.21.1 Da Copafasp À Apalufer .............................................................................204

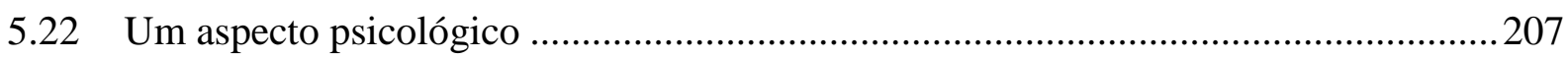

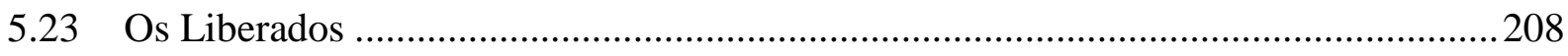

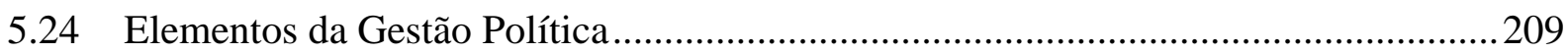


5.24.2 Aênese da burocracia das associações............................................................213

5.24.3 Mecanismos de prevenção da instauração da oligarquia.............................214

5.24.4 O fenômeno do contrapeso do poder .................................................................214

5.25 A Pacificação do Entorno do assentamento .................................................................218

5.25.1 A crise do ITESP diante dos movimentos sociais ....................................................218

5.25.2 A Questão das Propostas Queimadas .......................................................................219

5.25.3 O simbolismo dos elementos de cultura material ......................................................221

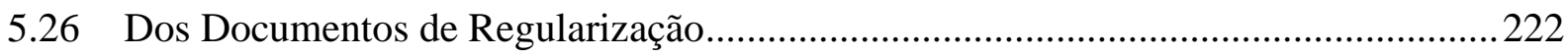

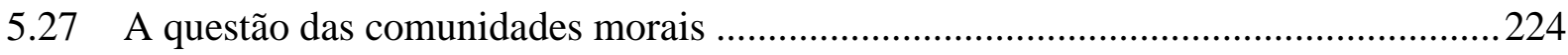

5.28 a construção da Igreja na via principal da Agrovila 1 .............................................226

5.29 A Rejeição da Comercialização via Cooperativas ....................................................227

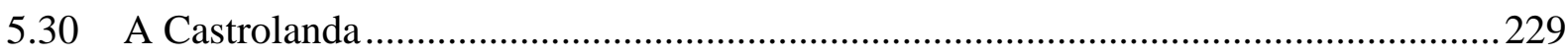

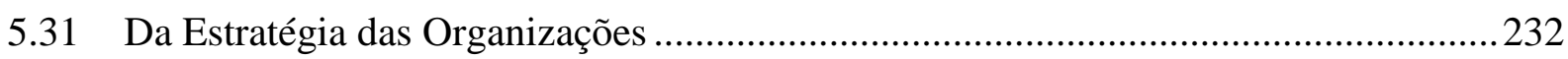

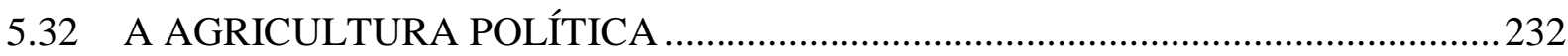

5.33 AS CONDIÇÕES DA ATUAÇÃO ENTRE COPAVA E A COAPRI ......................234

5.34 O PROBLEMA DA TRANSFERÊNCIA DOS LOTES .........................................235

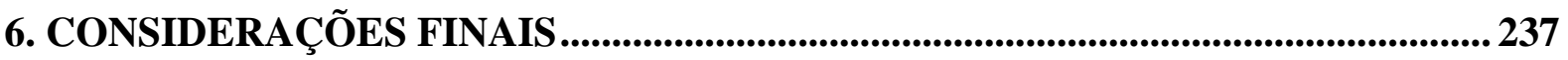

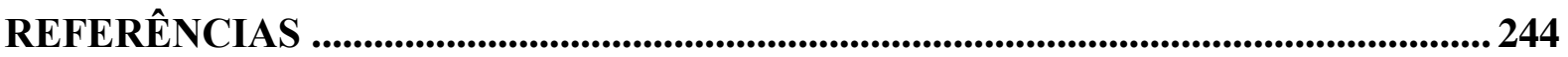

APÊNDICE A - ROTEIRO DE ENTREVISTAS SEMIESTRUTURADAS ….............256

APÊNDICE B - QUESTIONÁRIO...................................................................................... 258 



\section{INTRODUÇÃO}

Ao longo dos anos de 1990, a agricultura brasileira foi ganhando protagonismo na economia brasileira, devido a uma gama de reformas estruturais feitas ao longo dessa década.

Assistiu-se a uma revolução tecnológica no meio rural, que rearranjou os fatores de produção do setor agrícola e atingiu o programa de implementação da reforma agrária no Brasil, acabando por excluir pequenos produtores do mercado, intensificar a concentração fundiária, despovoar o meio rural, e provocar impactos ecológicos, devido ao uso intensivo de defensivos agrícolas os efeitos da monocultura extensiva (Navarro, 2015; Oliveira, 2007).

Nesse cenário, verificou-se a atuação de movimentos no sentido reativo à mudança como o movimento cooperativista —atraindo um grande número de pequenos produtores rurais, desprovidos do capital necessário para a modernização de sua produção, buscando acesso a mercados - e o movimento dos sem-terra — que reuniu populações excluídas do

processo produtivo e sem acesso à terra (Martins, 1999; Pinho, 2007). Paradoxalmente, a década de 1990 assistiu, apesar dessa ascensão do cooperativismo, a uma série de dificuldades das cooperativas em manter-se em operação, o que implica na constatação da relevância do tema e de sua proposição no Brasil (Crúzio, 1999).

Assim, é a partir da disputa das agendas entre os diferentes atores políticos que as relações de poder passam a ser importantes. As propostas de cooperação e de formação de cooperativas são influenciadas pela forma como se dá a organização e a composição dos grupos sociais proponentes.

Logo, a capacidade de influenciar propostas e modelos de organizações cooperativas, determinar finalidades para a cooperação, assim como o amparo legal pelo qual se dão as propostas cooperativas, é resultado da conformação de um cenário específico dessas relações de poder. A capacidade de promoção de propostas de cooperação é ligada à representação dessas demandas diante da atuação do poder público.

Vários autores trataram do relativo sucesso dessas cooperativas, discutindo suas estratégias e implicações em sua organização. Sigismundo Bialoskorski Neto, por exemplo, aponta para o fenômeno da modernização do cooperativismo brasileiro em que, a partir da Constituição de 1988, emerge o conceito de "autogestão". Essa mudança implicou o afastamento do Estado das atividades das cooperativas, e fez-se necessário que os cooperados tivessem um monitoramento das ações dos administradores das cooperativas, além de 
auditorias independentes por meio da profissionalização da gestão da empresa cooperativa (Bialoskorski Neto, 2000b; Crúzio, 1999).

Com isso, o modelo de sucesso da transformação da cooperativa numa corporação acaba sendo dominante pelo suposto de uma profissionalização da gestão ser considerada necessária. Um exemplo que inspirou a tomada desse modelo para o estudo de cooperativas é o da experiência de Mondragón, nos países bascos na Espanha (Gibson-Graham, 2003; Hodgson, 2015).

Porém, a concepção desse modelo não reconhece a questão de que a alternativa de produtores ou de trabalhadores pela via da cooperação é precedida por uma mobilização política que tem objetivos políticos e sociais, como no caso como reação a mazelas ou outros temas. Em outras palavras, o estudo das cooperativas pelos empreendidos em administração acabam tendo pouca capacidade, ou mesmo atenção, às condições sociais e políticas de uma cooperação econômica.

A estratégia das organizações vista apenas pela sua dimensão econômica, a exemplo das concepções sobre integração vertical e horizontal, é insuficiente para a compreensão do fenômeno da formação de associações e cooperativas em grupos sociais em mobilização. $\mathrm{O}$ desenvolvimento por essa via de gestão seria comprometido, também nas cooperativas tradicionais, porém, por ter especificidades quanto a problemas da ação política dos movimentos.

Sendo assim, a apreciação das relações de poder nas organizações passa a ser relevante, pois as mobilizações sociais são a forma de organização social e política de representação desses sujeitos sociais. Dessa forma, cabe compreender a relação de poder existente na mobilização social e sua influência na formação da associação cooperativa no momento de seu estabelecimento.

Dessa forma, as questões fundamentais de pesquisa deste trabalho são: Quais os fatores que influenciam as estruturas de governanças de associações cooperativas agrícolas, tendo em vista a atuação de movimentos sociais que traçam, a princípio, a formação de uma ação coletiva com objetivos políticos? Como é possível compreender o papel desses movimentos na configuração das estruturas de governança?

Este trabalho se justifica por atentar à especificidade de seu objeto, a cooperativa, como interlocutora de movimentos sociais de diferentes naturezas como formação de origem de sindicatos de trabalhadores industriais, ou por apoio de mobilizações ecológicas como no caso de cooperativas formadas para reciclagem e reaproveitamento de materiais. Contudo, o caso que se focaliza nesse trabalho é o do Movimento dos Trabalhadores Rurais Sem-Terra 
(MST). Trata-se, sobretudo, de analisar a relação entre as agendas destes na estrutura de governança da cooperativa, dentro do ambiente institucional onde se encontra inserida.

A relevância deste estudo também se dá pelo fato de que trabalhos sobre os estudos em economia agrícola, como os de Bialoskorski Neto, analisam as interações de cooperativas e do cooperativismo, sob as mais variadas perspectivas, com indivíduos, com o Estado, com empresas não cooperativistas, etc. (Bialoskorski Neto, 1998b). Entretanto, há uma carência de abordagens sobre outras organizações sociais, como o próprio MST. Essa ausência acaba refletida, por exemplo, em outros trabalhos que tratam da questão estratégia de gestão das cooperativas sob as concepções do sistema agroalimentar (SAG), como os de Decio Zylberzstajn (1994; 2002;2014) e os de Bialoskorski Neto (1998a) (Bialoskorski Neto, 1998a; Zylbersztajn, 1994, 2002, 2014).

Douglass North atentou a esse fenômeno ao afirmar que a mudança das instituições vem das percepções dos empreendedores nas organizações políticas e econômicas, além do papel que dogmas e ideologias têm, no nível individual, ao serem dotados de uma concepção normativa do mundo e suas implicações pelo processo subjetivo de processamento de informações (North, 1990).

Masahiko Aoki trata da dinâmica no processo de mudança das instituições ao desenvolver uma unidade da interpretação, contendo o entendimento da interação entre os agentes e do papel de fatores políticos, sociais e econômicos. O autor considera esse processo a partir de uma mudança endógena que se dá pela formação da racionalidade dos agentes, defendendo, entretanto, que não há uma hierarquia causal neste fenômeno (Aoki, 2007).

Oliver Williamson discute essa relação a partir de um modelo de que ele compreende como o de estruturas de governança. Ele o faz elaborando um modelo que compreende três níveis da análise institucional: o ambiente institucional, os indivíduos, e as estruturas de governança que se formam -influenciadas e influenciado- os dois primeiros (Farina, Azevedo \& Saes, 1997; Saes, 2000).

Em outro trabalho, Bialoskorski Neto apresenta os elementos básicos da formação de uma cooperativa formal. A Assembleia-Geral, formada pela votação de um voto por membro, a partir do conjunto de todos os membros; o Conselho de Administração, constituído para a gestão do empreendimento; e por fim, o Conselho Fiscal, com as atribuições de fiscalização da gestão e do orçamento (Bialoskorski Neto, 2000a). Daqui parte um modelo básico de estrutura de governança das cooperativas que consiste basicamente da constituição de um quadro dirigente que representa a entidade econômica: 
Figura 1 - Organograma básico de uma cooperativa

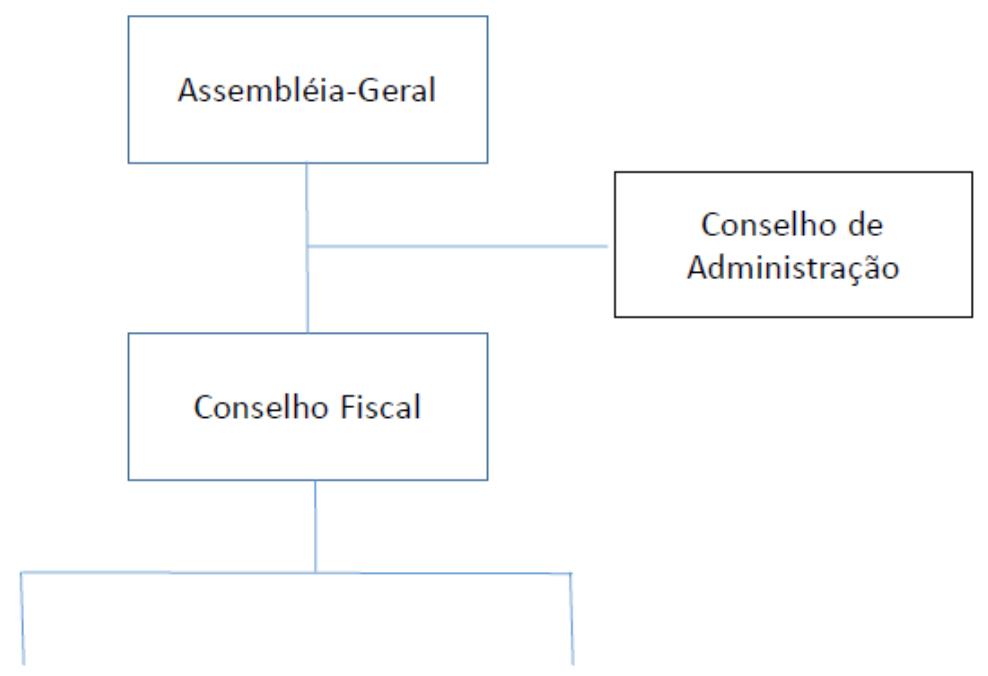

Fonte: Bialoskorski Neto (2000, p.238).

A figura 1 demonstra a relação entre os três órgãos fundamentais para a formação de cooperativas no Brasil, a Assembléia-Geral, o Conselho Fiscal e o Conselho de Administração. Em azul, Assembléia-Geral e Conselho Fiscal são órgãos que operam de forma periódica, ou seja, não permanente. Nesse sentido, tanto na relação entre os membros componentes, como na sua relação com os demais membros da cooperativa, não há uma relação hierárquica, de comando. A diferença é que entre esses dois órgãos é que a Assembléia-Geral é em si o conjunto de todos os membros, enquanto o Conselho Fiscal, ainda que tenha sido escolhido por representação, é um órgão aberto à entrada e à demanda dos demais membros da organização, como indicado pela chave aberta abaixo do quadro do Conselho Fiscal.

Já o Conselho de Administração, em cor preta, se trata de um órgão que opera permanentemente nas atividades da cooperativa e que, ainda que se possa destituí-lo ou rechaçar a sua autoridade, tem uma prerrogativa de coordenação e comando sobre os demais membros. Uma vez estabelecido, se trata de um grupo fechado e que toma para si uma parcela de decisões da organização cooperativa que já não passam mais pela discussão com os demais membros.

Diante de sua relação com o mercado, essa estrutura de governança também se incorpora ao sistema de agribusiness e de transações típicas da interação em rede entre produtores e consumidores. Nesse ponto se observa a sua posição da cadeia de comércio e a composição de suas transações (Zylbersztajn, 2000, p. 14-15). 
Para responder às questões levantadas, a dissertação será dividida em seis capítulos, incluindo o desta introdução. O segundo capítulo trata das questões metodológicas envolvendo esta pesquisa. Já o terceiro aborda a economia institucional, apresentando alguns trabalhos sobre a interação dos grupos e, finalmente, a formação de organizações e instituições. Porém, ressalta-se aqui a natureza crítica dessa abordagem e da incorporação teórica do problema do poder na teoria social e institucional em economia. O quarto tem o objetivo de apresentar dois precursores dos estudos sobre o cooperativismo: Alexander Vassilievich Chayanov e Ivan Vasily Emelianoff. A partir deles, trata-se de demonstrar duas tradições distintas da teorização sobre o cooperativismo e, em especial, o cooperativismo agrícola.

O quinto capítulo, por fim, apresenta a pesquisa de campo que visa demonstrar a relação entre os conceitos desenvolvidos nos capítulos anteriores. Aborda o caso do Assentamento Pirituba II e suas experiências associativas e cooperativas, diante da influência de outros agentes, como os movimentos sociais, entre os quais o Movimento dos Trabalhadores Rurais Sem-Terra (MST).

Por fim, o último capítulo é dedicado à apresentação das considerações finais resultantes da pesquisa. Nele se procura, além da apresentação, apontar aos pontos relevantes para pesquisas futuras, assim como reconhecer as limitações da pesquisa empreendida e apresentada aqui. 


\section{MÉTODO}

A natureza desta pesquisa é qualitativa. Ou seja, ela tem um ímpeto investigativo compreensivo que se expressa na concepção do problema, na delimitação do seu objeto e na abordagem das teorias existentes a esse respeito, que será esmiuçado adiante neste capítulo.

Assim, o método escolhido para a realização da pesquisa qualitativa se divide em dois procedimentos. $\mathrm{O}$ primeiro é o de pesquisa bibliográfica a respeito dos temas relacionados. $\mathrm{O}$ segundo procedimento é o da pesquisa a campo com a tomada de um caso específico, o do Assentamento Pirituba II.

\subsection{A Pesquisa Bibliográfica}

A pesquisa bibliográfica é feita a partir de dois eixos. Um eixo é o do estudo da economia institucional em que se empreende um esforço de apropriação teórica da questão da interação social e do fenômeno da ação e do comportamento a partir dos estudos em organizações.

Nele, se toma contato com ideias e obras da Economia Institucional. Porém, a partir de uma perspectiva crítica da própria economia institucional se toma contato com autores que trataram diretamente dos estudos de organizações na própria área de Administração.

Inclui-se aqui a incorporação de contribuições teóricas da economia institucional, sobretudo, em dois de seus campos. Um é o da Nova Economia Institucional que tem a referência de Douglass North. Já o outro campo, é o do neoinstitucionalismo representado por Geoffrey Hodgson.

Já o segundo eixo desta pesquisa diz respeito aos estudos sobre a cooperação, em relação ao setor agrícola. Nele se retoma o desenvolvimento do conhecimento científico em relação aos estudos de cooperação em economia que tem como marco a revolução russa, em especial retomando dois autores à margem do fenômeno, Chayanov e Emelianoff, que à sua maneira empreenderam pesquisas nesse campo.

Além dessa retomada teórica por parte de autores especificamente da área de cooperação agrícola, retoma-se aqui os estudos sobre a cooperação agrícola, feitos no Brasil, tomando a partir das concepções presentes tanto na academia, como em movimentos sociais e outros tipos de movimentos populares dentro do contexto da reforma agrária. A partir disso procura se estabelecer termos comuns na comunicação entre um debate já presente no Brasil e outro que se dá num âmbito contemporâneo por concepções alheias a este. 


\subsection{A Pesquisa em Campo}

O objeto de estudo desta dissertação é a cooperação no Assentamento Pirituba, São Paulo. A escolha deste assentamento deve-se principalmente a dois fatores: (1) ser um dos assentamentos mais antigos do Brasil fundado há 33 anos, que nos permite caracterizar várias gerações e sua pluralidade de estratégias de cooperação, responsáveis por diferentes estruturas de governança; e (2) ter destaque do ponto de vista técnico-produtivo, motivo da grande atenção por parte dos estudiosos e ativistas de movimentos no campo brasileiro, que os consideram um modelo de sucesso de intervenção agrária no País.

Seguindo Hodgson (2013), para realização desta pesquisa, consideramos o contexto social relevante para o entendimento da economia em geral, assim como das estruturas de governança e em particular das associações cooperativas agrícolas de pequenos produtores. Isso se dá por conta da influência dos fatores sociais na sua configuração e na tomada de decisão dos indivíduos.

\footnotetext{
It is more than the sum of individuals, and to understand that social reality we have to consider social relations as well. Economics must unavoidably be about social structures of power and position, as well as the properties of individuals. [...] Notwithstanding the importance of these features of individuals, a social science must also address relations between individuals and the particular forms of these relations. These forms include social institutions, organizations, positions, and other structures. These entities are sustained through individuals interacting with some shared meanings and understandings, in part built on precedent and derived from practices in the past. These entities are irreducible to individuals, just as real as individuals themselves, and unavoidable among the explanantia. (Hodgson, 2013, pp. 43-44).
}

Além disso, considera-se que, além da objetividade histórica dos acontecimentos, pelas quais as associações são expostas, a compreensão da memória coletiva dessa comunidade a respeito do significado das experiências cooperativistas passadas e das remanescentes é um exercício teórico fundamental.

Partindo dessa premissa e do entendimento de que a ação coletiva que surge por meio dos movimentos sociais é condicionada por constrangimentos de natureza política, faz-se necessário a realização de uma aproximação com a realidade dessa comunidade. Quanto a isso, Uwe Flick (2009) explica que o problema do debate sobre a pesquisa qualitativa se faz 
entre a Escola de Chicago, que propõe a observação, a interação e por fim, uma participação direcionada observando como princípio o distanciamento do investigador diante do objeto estudado; a etnometodologia, que propõe uma imersão de bom propósito ou boa-fé por parte do investigador em que se procura por meios de métodos de descrição entender os processos sociais da coletividade estudada desde seu interior; e, em uma condição intermediária, se encontra a sociologia existencial que propõe uma participação investigativa, no qual se procura por parte de um investigador externo apresentar os achados do objeto estudado em campo. Assim, quanto ao acesso, Flick afirma:

Finally, providing more information on the background, intentions, procedure, and results of the planned research does not necessarily lead to more clarity, but rather may lead to more confusion and produce the opposite of understanding. That is, if you negotiate entry to an institution, this is less a problem of providing information than one of how to establish a relationship. In this relationship, enough trust must be developed in the researchers as persons, and in their request, that the institution - despite all reservations - gets by being involved in the research.

However, it remains necessary to underline that the discrepancies of interests and perspectives between researchers and the institutions under study cannot in principle be removed. However, you can minimize them if you manage to develop trust on the side of the participants and institutions far enough to forge a working alliance in which research becomes possible. (Flick, 2009, p. 109).

Considera-se essa observância como uma condição necessária para a construção do conhecimento diante das contingências que a realidade de uma pesquisa social impõe para a limitação da verdade científica.

Escolheu-se, portanto, para responder à pergunta de pesquisa: como as estruturas de governança das organizações associativas se configuram diante do seu meio social, tratar dos elementos intersubjetivos da interpretação do mundo e da narrativa dos agentes envolvidos para a realização da cooperação. O caráter qualitativo implica a tarefa de imersão do pesquisador no local do fenômeno a ser estudado buscando reduzir ao máximo a perturbação dos agentes.

\subsubsection{A Natureza da Pesquisa}

Dado o caráter da pergunta de pesquisa que trata da formação de elementos da estrutura de governança em organizações associativas agrícolas, tem-se assim um problema 
de pesquisa que requer um método qualitativo. Por isso, deve-se esclarecer sobre os parâmetros nos quais a pesquisa foi realizada, no intuito de construir um conhecimento com validez científica.

De acordo com Creswell (2003), a questão da construção do conhecimento científico é permeada por paradigmas distintos. Nesse sentido, ele entende que há quatro escolas de pensamento sobre o conhecimento que procura tratar em sua obra: o pós-positivismo; o construtivismo; a advocacia participante; e o pragmatismo (Creswell, 2003).

Segundo Creswell, o pós-positivismo, termo que se refere a um método científico de caráter empírico ou quantitativo, que desafia a ideia de uma verdade absoluta do conhecimento suposta pelo positivismo, mas que do ponto de vista filosófico, contém um determinismo entre causas consequências ou resultados dos fenômenos. Segue-se a isso que a observação dos fenômenos é submetida ao escrutínio de atribuições numéricas da realidade, mensurações e experimentações processuais de hipótese a fim de revisar e corrigir a teoria, a partir de um pesquisador individual.

Já o construtivismo para Creswell reclama para si a produção de conhecimento científico por meio da interação social. É a partir dessa que se constrói uma realidade socialmente concebida, mediante uma relação intersubjetiva, constituindo uma realidade complexa não se atendo a ideias ou categorias estritas.

Assim, pesquisas de caráter construtivistas assumem a subjetividade extraindo das experiências e das compreensões da realidade, seus significados e seus padrões, levando em conta a subjetividade do próprio investigador. O cabedal cultural e histórico dos envolvidos na pesquisa, e seu respectivo entendimento, é um elemento condicionante para a compreensão situacional dos sujeitos sociais investigados. Assim esclarece Creswell:

Assumptions identified in these works hold that individuals seek understanding of the world in which they live and work. They develop subjective meanings of their experiences-meanings directed toward certain objects or things. These meanings are varied and multiple, leading the researcher to look for the complexity of views rather than narrowing meanings into a few categories or ideas. The goal of research, then, is to rely as much as possible on the participants' views of the situation being studied. The questions become broad and general so that the participants can construct the meaning of a situation, a meaning typically forged in discussions or interactions with other persons. The more open-ended the questioning, the better, as the researcher listens carefully to what people say or do in their life setting. Often these subjective meanings are negotiated socially and historically. In other words, they are not simply imprinted on individuals but are formed through interaction with others (hence social constructivism) and through historical and cultural norms that operate in individuals'. Thus, constructivist researchers often address the processes"of interaction among individuals. They also focus on the specific contexts in which people live and work in order to understand the historical and cultural settings of the participants. Researchers recognize that 
their own background shapes their interpretation, and they position themselves"in the research to acknowledge how their interpretation flows from their own personal, cultural, and historical experiences. The researcher's intent, then, is to make sense of (or interpret) the meanings others have about the world. Rather than starting with a theory (as in postpostivism), inquirers generate or inductively develop a theory or pattern of meaning. (Creswell, 2003, pp. 8-9).

Dessa maneira, a diferença entre o pós-positivismo e a construtivismo está também no caráter da ação pesquisador em que há a necessidade de uma interpretação por parte do investigar. Enquanto, no pós-positivismo o avanço teórico se dá estritamente pelo trabalho do pesquisador em verificar e testar hipóteses no sentido da construção teórica, no construtivismo há a necessidade de um esforço compreensivo por parte do investigador no sentido de, a partir dos dados de campo, construir uma teoria generalizante através de processos de raciocínio indutivos. Por conta disto, essa interpretação do significado, e de seus padrões, é parte constituinte do trabalho científico no construtivismo, não contemplado ou concebido no póspositivismo.

A terceira escola de pensamento científico tratada por Creswell é a da advocacia participante. Esta escola trata da natureza estritamente política dos problemas das relações exigindo por parte do conhecimento, e do investigador, uma intervenção emancipadora, crítica, ou transformadora da própria realidade social investigada. Ela se atenta a fatores de poder e a questões ligadas a agendas sociais de minorias, oprimidos ou populações vulneráveis.

Essa escola tem origens no pensamento marxista tendo tomado para si o ímpeto transformador da sociedade. Com isso, a ação participante por parte do investigador é um recurso para esse tipo de empreendimento científico. Porém, ao contrário do que se suporia por parte de outras pesquisas que tratariam da ideia da compreensão dos constrangimentos, também se teria a natureza desse tipo de conhecimento ao procurar emancipar os investigados deles.

Por fim, o pragmatismo é uma escola de pensamento que se baseia na ideia de que o conhecimento científico é construído a partir da ação, das situações e das consequências mais do que a partir de condições antecedentes, sendo o investigador totalmente livre para a suas escolhas quanto às técnicas e métodos. Nesse ponto o que se observa no pragmatismo é a ideia da aplicação como forma de construção do conhecimento por parte do investigador.

Com isso, o pragmatismo entende que o trabalho investigador deve conciliar diferentes métodos, a fim de superar a dualidade entre mente e realidade da mesma forma como dispensa a afiliação a um sistema filosófico específico. Assim, o trabalho do investigador é 
reflexivo no sentido de estabelecer inferências científicas a partir das consequências pretendidas, e obtidas, ao nível da ação ou situação produzida (Creswell, 2003).

Dessa maneira, por princípio, o conhecimento humano pode tomar formas distintas devido aos processos de cognição que ganham superioridade ou complexidade de acordo com os níveis de conhecimento atingidos. A circunscrição desse conhecimento ao campo científico se dá por conta da tomada de parâmetros como o rigor metodológico, a busca por objetividade e, sobretudo, o esforço ao nível do conhecimento do intelecto como meio de sua concepção enquanto conhecimento.

Outras disciplinas não científicas são igualmente necessárias para a produção do próprio conhecimento científico moderno como, por exemplo, a filosofia e a axiologia. Entretanto, uma característica do pensamento especulativo que opera no processo de investigação é que ele é dotado de um método específico.

Considera-se aqui que é a correspondência entre a elaboração de uma pergunta de pesquisa e o método ao qual se deve procurar construir conhecimento sobre ela que caracteriza uma determinada pesquisa. Dessa maneira, há duas formas elementares de produção de conhecimento científico social: uma por meio da pesquisa quantitativa, que procura quantificar processos, gerar indicadores, mensurar fatores e relacionar variáveis com base em dados gerados a partir de intervenções científicas tomadas por meio de instrumentos de pesquisa como questionários ou experimentos, avaliação e manipulação do meio; outra por meio da pesquisa qualitativa, que procura compreender processos, significados, fenômenos, discursos e narrativas, por meio de imersão social, observação, entrevistas, registros e análise de documentos (Creswell, 2013).

As fontes dos dados em pesquisas qualitativas podem ser de pessoas, como indivíduos, grupos ou coletividades; organizações, instituições e entidades; textos, publicados ou não, impressos ou virtuais; cenários e ambientes, materiais, visuais ou sensoriais e virtuais; objetos artefatos e produtos de mídia; e, por fim, eventos e acontecimentos (Mason, 2002, p. 52). Com isso, corrobora-se que os dados coletados sejam como definidos por Creswell (2007) citando a Miles e Huberman, ao abarcar o cenário, os atores, os eventos e o processo do fenômeno a ser estudado (Creswell, 2007, p. 190).

Entretanto, entende-se que, por conta da própria inter-relação entre as afirmações baseadas em pesquisas de diferentes naturezas que se deriva um terceiro tipo de pesquisa que envolve métodos mistos em que se procura colocar em diálogo ambos. O que se consegue observar é que, a partir da conjugação desses diferentes tipos de pesquisa, procura-se corresponder ao critério de objetividade e validez científica proposto pelo conhecimento 
científico, levando, de um a outro campo, críticas que possam complementar o trabalho empreendido com um propósito distinto, assim superando as limitações próprias de cada um.

É observando a essas diferentes formas de conceber a produção científica que se propõe nesse trabalho a noção de que o método científico é exploratório, em que se procura gerar construtos a partir dos dados de campo e da investigação teórica. Dessa maneira, o trabalho limita-se aqui a elaboração de construtos e categorias e não propriamente a uma codificação sistemática dos dados. Quanto a isto, tomam-se em conta as observações de Jennifer Mason (2002):

However, there are three main limitations with this form of simple indexing. The first is that although it may be a useful way to signpost the reader in general terms through an individual text, it may produce indexing categories so broad or bland as to be of limited further use, especially for the purposes of making comparisons or connections between more than one text. Second, any one piece of qualitative text is likely to address more than one topic or concept at a time, and therefore serial indexing may be inappropriate or impossible to apply. And third, serial indexing is unlikely to work very well in qualitative texts which do not have a uniform layout or follow an ordered sequence, or in non-text-based data. So, for example, it may be more useful for the categorization of texts with a standardized layout such as legal or administrative documents, and less useful for interview transcripts derived from semi-structured conversations or observational field-notes. (Mason, 2002, p. 151).

Em termos ontológicos, essa pesquisa trata da intersubjetividade proveniente da interação tanto dos sujeitos sociais investigados, como na sua relação com o investigador. Porém, reitera-se aqui o comprometimento com o critério de objetividade do conhecimento científico no sentido de que se procura delimitar a interpretação diante da apropriação dos dados. Assim, tomada a diretriz da busca de objetividade, reconhece-se também o intransponível caráter subjetivo dessa pesquisa.

Dessa maneira, epistemologicamente entende-se que a identificação de contradições enquanto um elemento da observação é concomitante a uma compreensão dialética da realidade. Nesse sentido, compreende-se tanto a transformação da realidade social dessa forma, como a própria relação entre os dados e a teoria, tanto em sua contradição como em sua complementaridade.

Considera-se de igual forma, assim como a partir da ressalva inicialmente feita que se tome a perspectiva do pensamento humano em sua dinâmica, a partir das suas situações e seus contextos condicionantes. É a partir da captação dessa realidade social na qual se inserem esses indivíduos que se extraem os elementos necessários para a compreensão do fenômeno.

Sendo assim, o que se procura por fim construir é a provisão de um resultado de um observador externo diante da compreensão da interpretação subjetiva dos membros internos 
dessa comunidade, buscando uma descrição da realidade concebida diante da confrontação teórica de caráter científico. Para isso, Mason explica:

\begin{abstract}
I think it is more accurate to speak of generating data than collecting data, precisely because most qualitative perspectives would reject the idea that a researcher can be a completely neutral collector of information about the social world. Instead, the researcher is seen as actively constructing knowledge about that world according to certain principles and using certain methods derived from, or which express, their epistemological position. Therefore, as a researcher you do not simply work out where to find data which already exist in a collectable state. Instead you work out how best you can generate data from your chosen data sources. For this reason, the term method in qualitative research generally is meant to imply more than a practical technique or procedure for gaining data. It also implies a data generation process involving activities that are intellectual, analytical and interpretive. (Mason, 2002, p. 52).
\end{abstract}

Deve-se, então, dado que os parâmetros do conhecimento em que essa pesquisa se entende enquanto um estudo de caso. Neste ponto procura-se atentar ao que Alves-Mazzotti (2006) expõe:

\begin{abstract}
$\mathrm{Na}$ verdade, o maior problema de grande parte dos trabalhos apresentados como estudos de caso é que eles não se caracterizam como tal. Refletindo uma visão equivocada sobre a natureza desse tipo de pesquisa, esses estudos são assim chamados por seus autores pelo simples fato de serem desenvolvidos em apenas uma unidade (uma escola, uma turma) ou por incluírem um número muito reduzido de sujeitos. Frequentemente, o autor apenas aplica um questionário ou faz entrevistas em uma escola, sem explicitar por que aquela escola e não outra, deixando a impressão de que poderia ser qualquer uma. Ou seja, a escola ou a turma escolhida não é um 'caso', não apresenta qualquer interesse em si, é apenas um local disponível para a coleta de dados. Em consequência, a interpretação desses dados é superficial, sem recurso ao contexto e à história. (Alves-Mazzotti, 2006, p. 639).
\end{abstract}

Assim, entende-se aqui que se trata de um estudo de caso exploratório de característica crítica como entendido por Robert Yin. O autor ao tratar da pesquisa qualitativa em estudos de caso, argumenta que a triangulação dos dados é uma alternativa cabível para a validação científica da pesquisa, sendo necessária para tal uma relação estratégica entre ela e os objetivos da pesquisa como um todo (Yin, 2001).

Já Robert E. Stake (2005) aponta para o fato de que a triangulação é uma saída para captação de diferentes perspectivas, situações e realidades em um estudo de caso. Nesse sentido, elas conseguem dar outras evidências que corroborem a interpretação dos significados feita pelo investigador (Stake, 2005). 


\subsubsection{Das Especificidades do Campo Brasileiro e das Técnicas Empregadas para a Coleta dos Dados em Entrevistas}

No que se refere especificadamente à pesquisa a campo, recorre-se ao trabalho de Maria Isaura Pereira de Queiroz (1991) quanto às diferentes formas das técnicas de gravação. Toma-se a sua obra por conta da sua experiência com esse tipo de pesquisa no campo brasileiro e na coleta de informações testemunhais, narrativas, memórias orais e, sobretudo, da extração do significado dos enunciados por parte dos entrevistados em questão. Cabe compreender a diferença entre a entrevista e o depoimento e a escolha pelo primeiro e não pelo segundo em nossa pesquisa. No caso, o depoimento supõe uma intervenção mais clara e assertiva por parte do entrevistador no sentido de dirigir e inquirir o entrevistado. Porém, ao tomarmos contato com os agentes presentes no campo, notou-se a necessidade de uma intervenção muito mais limitada dada a sensibilidade das informações a serem colhidas, além do suposto acirramento das disputas entre os grupos ali presentes, optando-se aqui, portanto, pela questão da coleta de dados parcialmente enquanto história de vida.

Nesse sentido, ela passa a tratar da questão da coleta de dados enquanto "arquivos orais" como chamados na França, ou enquanto uma "informação viva" que se dá a partir de uma fonte que contém elementos humanos que devem ser compreendidos em sua condição (Queiroz, 1991). Assim, se trava aqui um debate em torno à natureza do dado que se dá pelo presente ou por um passado recente.

Com isso, os momentos em que as entrevistas tratavam por alguma ocasião da fundação do assentamento, ou de experiências produtivas ou comerciais desses momentos, procurou-se entender não a sua relação direta com a objetividade dos acontecimentos enquanto fatos históricos, mas sim enquanto fatos sociais que dizem respeito à construção da racionalidade especificamente ligada ao presente.

Queiroz compreende a técnica da gravação da entrevista de história de vida, como uma técnica e toda técnica enquanto um mecanismo de captação do real. Assim, tece algumas considerações a respeito do tipo de pesquisa feita no meio rural brasileiro:

No meio rural, por exemplo, as mudanças extremamente rápidas ocorridas no estado de São Paulo atingem indivíduos de todas as camadas sociais; no entanto, as pesquisas, utilizem ou não história de vida, têm-se voltado quase que somente para as camadas inferiores. Não se atenta para o fato que ainda há poucos anos havia também, habitando em suas propriedades, grandes e médios proprietários, e desconhece-se como vivenciaram a transformação que se operou em suas existências com sua implantação nas cidades. Além deles, toda uma gama de indivíduos citadinos está ligada aos habitantes do meio rural, não por auferirem diretamente do 
solo o seu sustento, porém por servirem aos moradores urbanos: funcionários públicos (professores primários, tabeliães, delegados etc.), gente do setor terciário (pequenos e médios comerciantes, pequenos industriais, artesãos etc.). Como vivem eles as reviravoltas havidas com o êxodo dos campos e com as mudanças de relações de trabalho ali acontecidas? O esvaziamento do meio rural tem determinado também o esvaziamento das cidades dele dependentes - aspecto do problema permanece ignorado e praticamente não estudado. (Queiroz, 1991, p. 19).

É a partir dessa observação que se tomou algumas medidas na seleção do perfil dos entrevistados. Primeiro, como se trata de uma população de assentados e que corresponderiam aos citados como sendo das camadas inferiores, procurou-se mitigar esse tipo de dado ao selecionar dentre a população de assentados os que tinham papel proeminente ou notável na articulação da associação dos demais.

Nesse sentido, procurou-se extrair desses as percepções de um possível grupo dirigente em meio àquela população. Com isso, compreende-se que a situação de um assentado, não é a princípio a de uma camada inferior por excelência, mas que pode ter sido levada a essa condição, tendo tido origem em outras camadas sociais, não sendo nem estanques e nem permanentes enquanto condições sociais.

Segundo e como consequência do primeiro, haveria então uma extração de dados dirigida ou enviesada, o que comprometeria a coleta, dado que essa seleção poderia selecionar representantes dessa camada social que exporiam apenas uma narrativa ou uma concepção da defesa de seus determinados fins ou interesses. Assim, a fim de contornar essa situação, procurou-se a tomada da entrevista com sujeitos que estivessem à margem desses arranjos associativos, assim como observadores externos à coletividade, em especial, na sua intermediação com outras camadas sociais tendo como referência aos grupos de interlocução.

É, portanto, a partir da apreciação desses discursos que se procurou entender uma população que corresponderia às camadas inferiores, mas que se pudesse compreendê-la não apenas por sua própria percepção de si, ou da imagem que seus componentes querem expor de si. O fato de haver a percepção de um observador externo, e distinto dos do próprio meio, acaba por levantar as ressalvas na apropriação e na relação que se estabelece entre os fatos relatados pelos entrevistados e as teorias com as quais esse observador procura identificar explicações e correspondências.

Em sua obra, Queiroz trata também da relação que uma pesquisa individual trava com um trabalho feito coletivamente, por uma equipe de pesquisadores, como no caso da coleta de dados a partir da aplicação de questionários que eram utilizados em outras pesquisas da nossa faculdade. Quanto a isso ela diz: 


\begin{abstract}
Além de uma noção de coletividade (conjunto de indivíduos), a expressão encerra também uma noção de igualdade entre eles, uma vez que se desincumbem juntos das mesmas tarefas; não se trataria de uma divisão do trabalho no sentido orgânico, e sim de uma repartição de tarefas semelhantes. Como se trata de realizar algo coletivamente, há também uma noção de organização, de um arranjo tal que permite alcançar a finalidade proposta. A organização implica, portanto a existência de uma estrutura, informal quando não existem normas precisas estabelecidas para se alcançar a finalidade proposta; formal, quando existem as normas. E a um e outro caso de estrutura acompanha também uma forma específica de liderança, paralela e da mesma natureza: liderança informal na primeira alternativa, quando um dos componentes do grupo tende a ser ouvido e seguido espontaneamente; liderança formal quando o líder, apoiado na estrutura vigente, tem explicitamente autoridade para ser o ordenador, o condutor, o animador do trabalho todo, podendo executar ou não as tarefas juntamente com os demais. (Queiroz, 1991, p. 35).
\end{abstract}

Nesse sentido, o trabalho aqui proposto não seria possível sem a colaboração de outros agentes ligados à pesquisa no mesmo campo e área coordenados pelo corpo de professores responsáveis. Nesse ponto, o que se pode observar é que a coletividade formada entre o grupo de investigadores se formou durante a realização das suas atividades, compreendendo assim a possibilidade de uma apropriação parcial dos trabalhos realizados individualmente dentro de um conjunto como um todo.

Assim, considera-se que o manuseio dos dados deve se dar por meio da triangulação entre os dados levantados e outros procedimentos de pesquisa. Assim, considera-se o uso de dados verbais, dados etnográficos e dados visuais. Nesse sentido, as fontes teóricas e as dos dados levantados passam a ser corroboradas pela relação desses com o problema a ser investigado.

\title{
2.2.3 Modelo de análise
}

O método com o qual se faz as afirmações a respeito dos achados dessa pesquisa é o da identificação de correspondências ou aproximações entre a realidade percebida, observada e em algum grau experienciada e as interpretações feitas nessa pesquisa a respeito das teorias existentes apreciadas inicialmente. Reconhece, com isso, que a subjetividade do investigador fique restrita a uma discussão hermenêutica e exegética das teorias, algo que em sua própria constituição não represente um prejuízo ao caráter científico do conhecimento humano apresentado aqui.

Tendo com esse objetivo, foram realizadas diversas viagens ao assentamento onde se buscou habituar e se familiarizar com a população dos assentados em seu conjunto. Nesse sentido, o que se pode perceber é que as informações coletadas na medida em que nos tornamos mais familiar passam a ser cada vez mais reveladoras, já que os relatos se tornam 
desprovidos de alguma preocupação consequente, de formalidade, ou impessoalidade.

Nesse ponto deve-se esclarecer que se concebe aqui que a realidade social acaba por sua vez construída também enquanto objeto do conhecimento. Assim, toma-se que a análise será feita por categorias que tem como objetivo unir o arcabouço teórico com o trabalho empírico.

As categorias de análise das interações sociais entre os sujeitos individuais não quais se configuram instituições são as seguintes:

1. As organizações

1.1 A unidade familiar de produção

1.2 A unidade associativa observada a partir da sua função enquanto: (1) unidade de produção, (2) unidade de aquisição, (3) unidade de consumo.

2. O quadro administrativo (gestão e decisão)

3. As relações interativas

3.1 A troca social (troca, transação e barganha)

3.2 A articulação social (aliança e coalizão)

3.3 A reciprocidade (ajuda mútua, manejo de bens comuns)

Dentro de um quadro geral dos agentes sociais envolvidos, as posições dos agentes fundamentais em sua interação e potencial associação econômica são esquematizadas nas figuras apresentadas a seguir.

Figura 2 - Relação organizacional entre cooperativa e produtores assentados

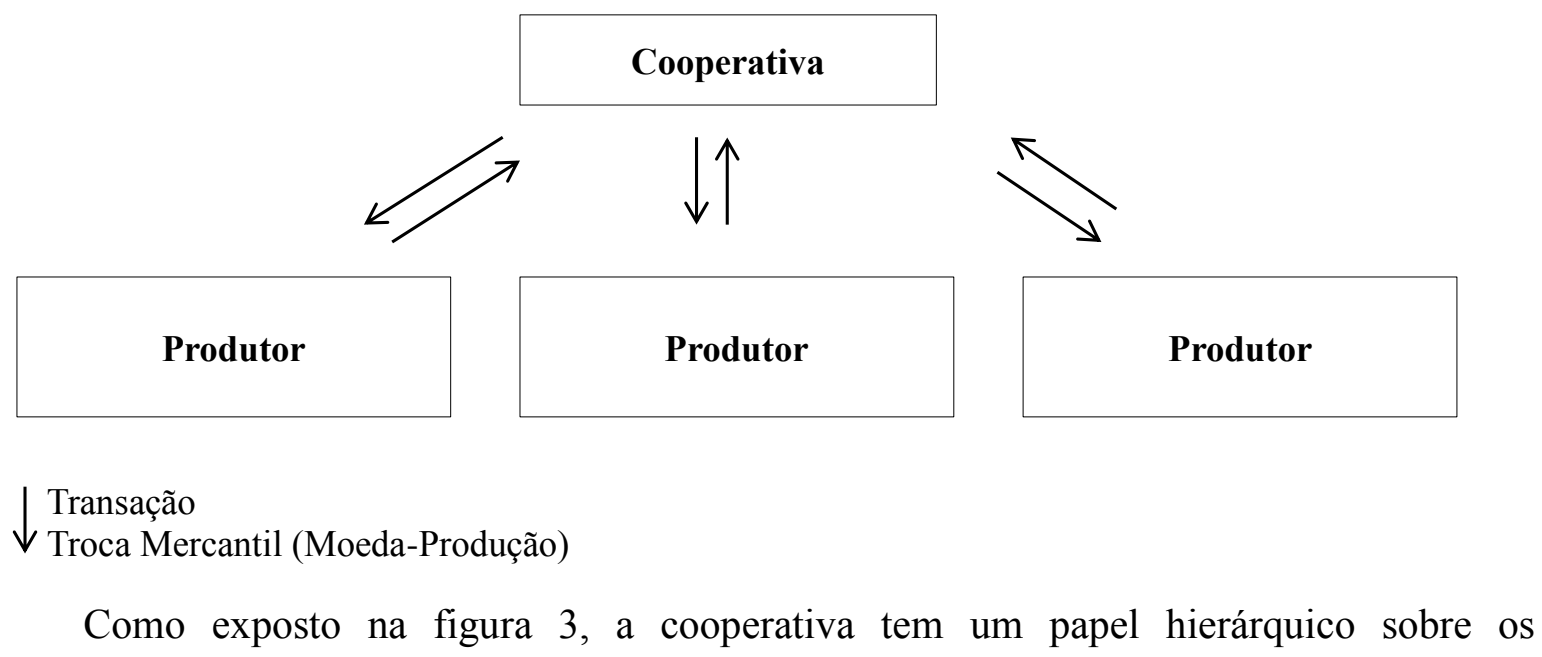


produtores. Nela se reproduz a forma de interação na qual, a cooperativa entrega a produção agrícola à cooperativa que remunera em moeda. Essa forma de transação acaba por delimitar o interesse de cada unidade apenas na relação com o outro, sem identificar o sujeito individual de cada parte dessa representação.

A Figura 4, a seguir, apresenta a relação organizacional entre os membros da família na tomada de decisão dentro de uma unidade familiar de produção, de acordo com a lógica teórica de Chayanov (2014). A ideia aqui é representar a dinâmica social do interior da unidade familiar concebida enquanto unidade de produção.

Figura 3 - Decisão familiar

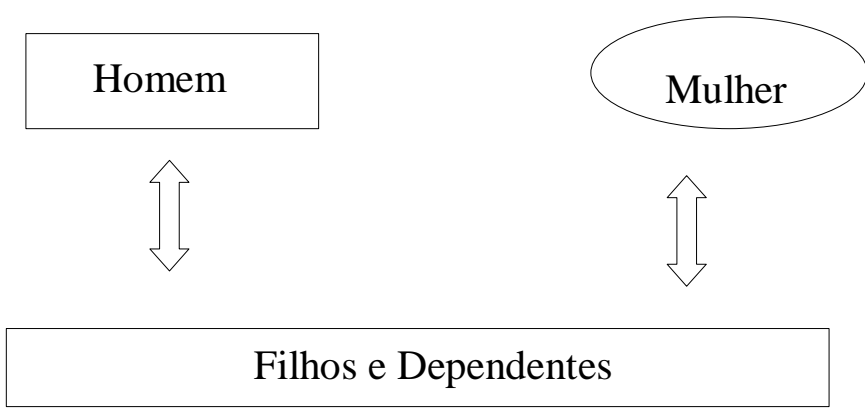

Porém, ao localizar-se dentro de um âmbito de mercado, esta unidade de produção de âmbito familiar tem uma finalidade para a sua atividade. Ela se insere em uma cadeia de produção na qual ela se coloca na posição inicial do processo de produção e de consumo, diante do escoamento de seu produto.

Este fluxo da cadeia de produção pode ser visto na Figura 5 a seguir. A unidade associativa composta pelos grupos de trabalho, associações ou cooperativas (Emelianoff, 1995) e agregado de unidades familiares são observados a partir da sua função enquanto: (1) unidade de produção, (2) unidade de aquisição, (3) unidade de consumo. 
Figura 4 - Fluxo da cadeia de produção

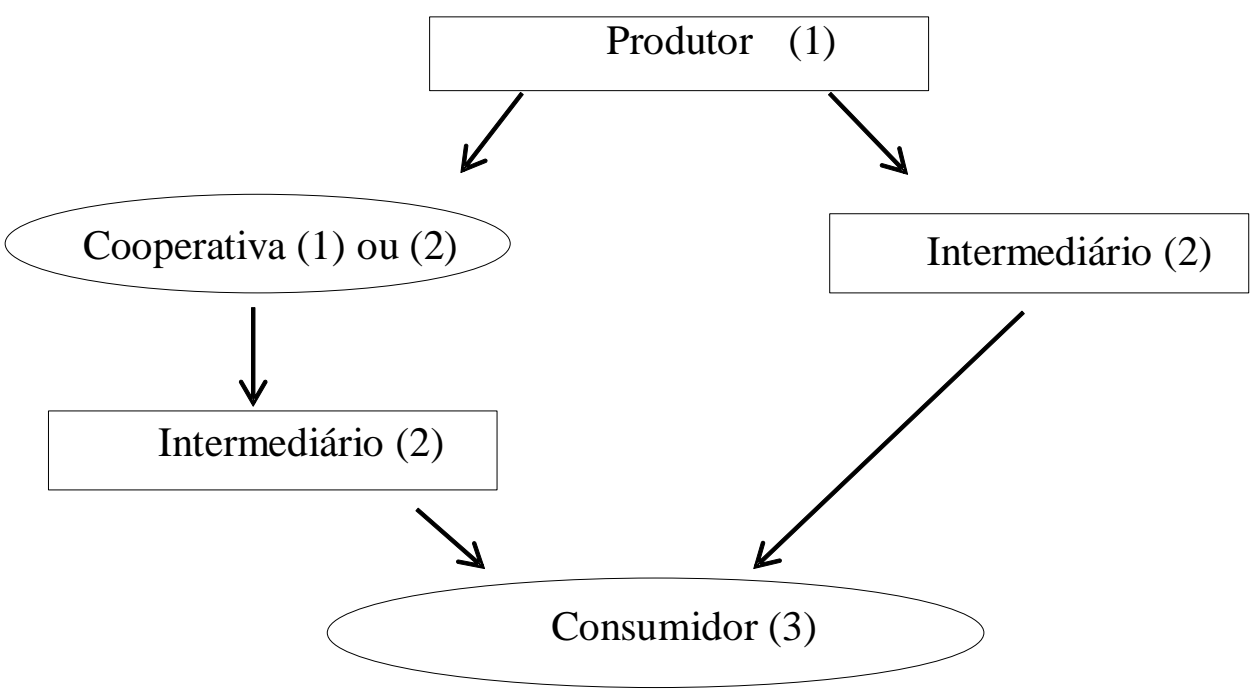

Como se nota, há a possibilidade de duas decisões pelo produtor. Uma é a de venda por meio do intermediário. A outra é a pela articulação da intermediação de mercado através da cooperativa em que esta pode decidir tratar com um intermediário ou diretamente com o consumo em substituição ao intermediário.

A relação entre a decisão do produtor e a decisão desta organização de representação também tem uma dinâmica interior. Ela se realiza através do destacamento de funções em que um corpo de gestão, no papel do quadro administrativo, se destaca dos demais, ampliando o alcance de sua operação.

Na Figura 6, a seguir, pode-se observar o quadro administrativo de gestão e de decisão. Em que há uma relação mútua entre membros de dentro e de fora desse corpo e que simultaneamente se institui pelo meio do quadro administrativo, como o Conselho de Administração, uma relação de comando dele sobre os membros externos como a forma de sua interação. 
Figura 5 - Configuração da gestão na estrutura de governança

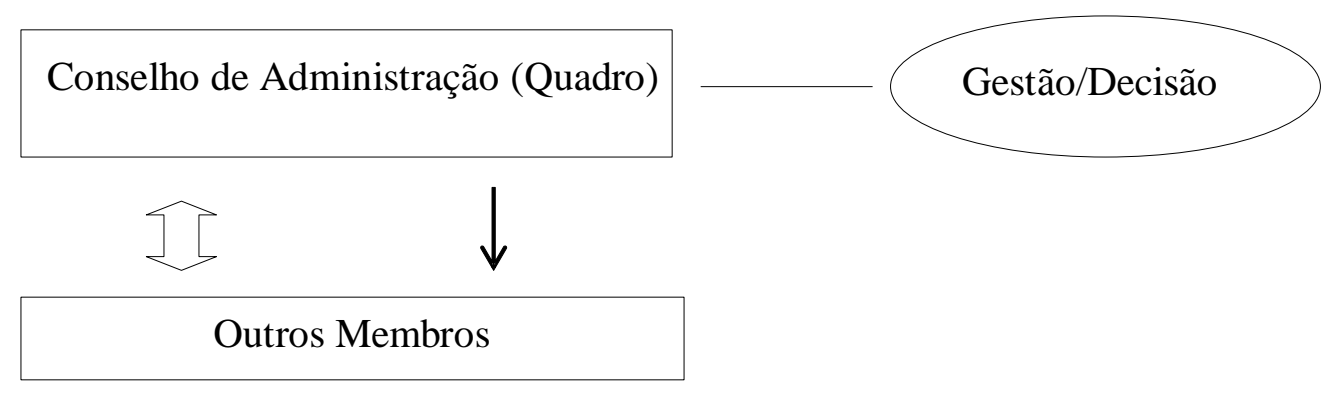

Contudo, cabe observar o estabelecimento dessa organização e a disposição dos diferentes membros da organização ao estabelecer esse corpo destacado ao qual se delega parte das funções de comando do coletivo. A Figura 7, a seguir, exibe a relação da assembleia geral com seus membros em termos de relações interativas, a troca (troca, transação e barganha) e a articulação social (aliança e coalizão).

Figura 6- Assembleia Geral e as coalizações

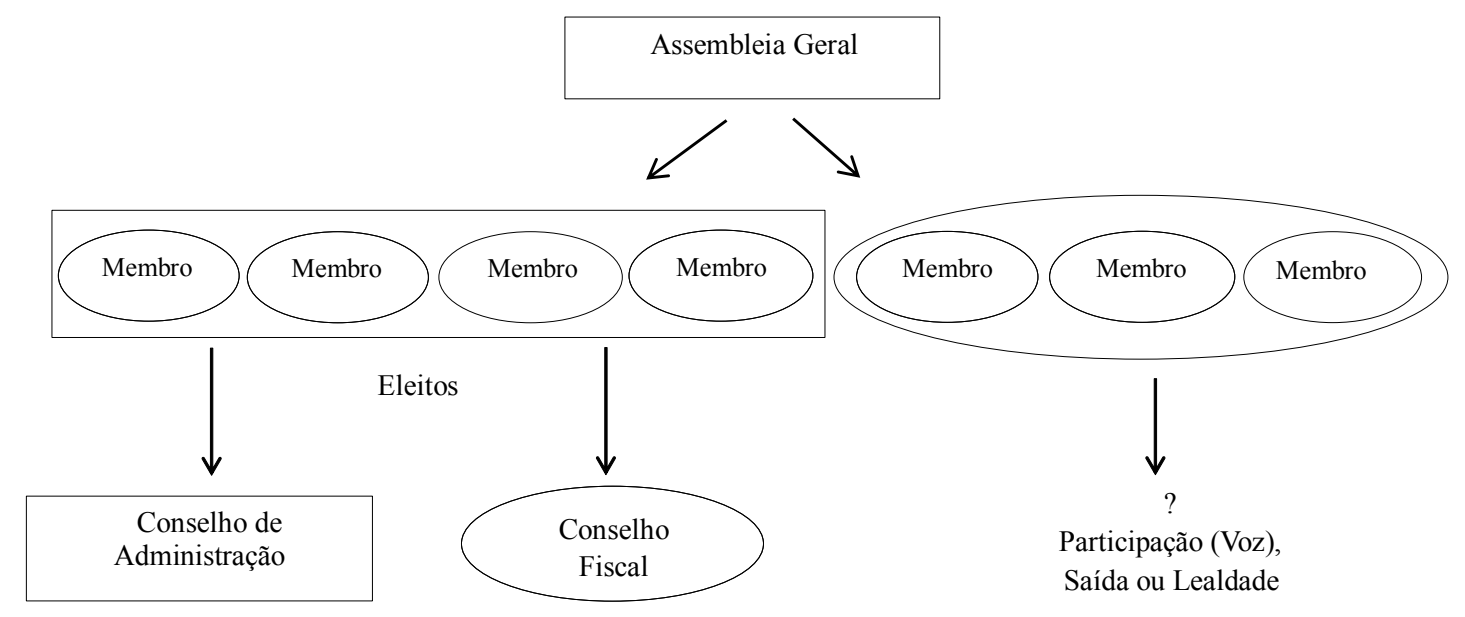

Por fim, as 8, 9 e 10 apresentam as estruturas de reciprocidade (Sabourin, 2009), que ocorrem a partir da Ajuda Mútua (Mutirão) e/ou Manejo de Bens Comuns. Estas podem se configurar de três maneiras. A primeira é a binária simétrica ou assimétrica (ex.: casamento, compadrio, amizade), como se vê na Figura 8. 
Figura 7 - Estrutura de reciprocidade binária simétrica ou assimétrica

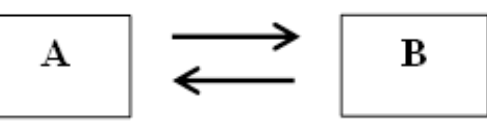

A segunda é a ternária unilateral ou bilateral (ex. envolvendo três partes (intergeracional [avós, pais, filhos]) ou duas partes, que doam a um receptor cuja contraparte é a sua reprodução por parte deste, sob a pena de sanção) [ou em outros termos, o caso da cooperativa que recebe dos produtores].

Figura 8 - Estrutura de Reciprocidade Ternária - Unilateral ou Bilateral

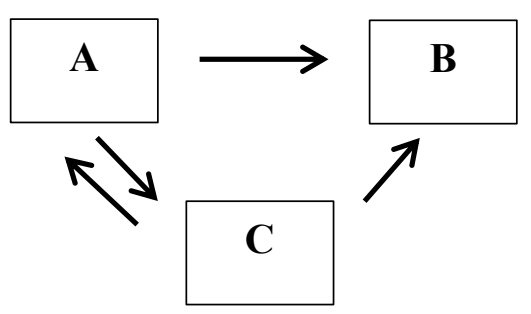

A terceira maneira de se configurar a estrutura de reciprocidade é em rede, na qual vários agentes se relacionam entre si, de forma circunstancial, sem nenhuma categorização especial a respeito de um ou de outro (ex.: reciprocidade centralizada, na qual há um agente que concentra as ações de reciprocidade um chefe, ou um patriarca).

Figura 9 - Estrutura de Reciprocidade em rede
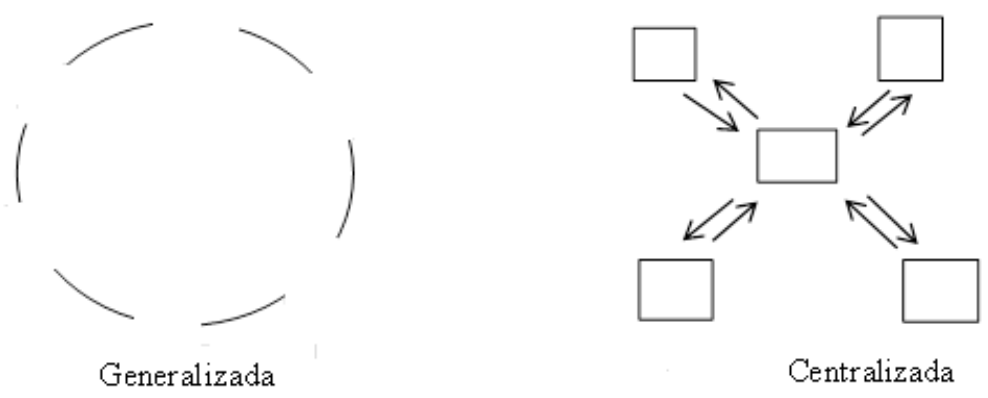


\subsubsection{Procedimentos de coleta de dados}

Os seguintes sete procedimentos foram realizados na coleta de dados para análise da pesquisa:

1. cinco viagens, em que se buscou uma aproximação gradual com as pessoas da área selecionadas para o estudo. ${ }^{1}$ No total foram 21 dias de vivencia no assentamento;

2. participante como observador das atividades realizadas pelos assentados;

3. registro de imagens referentes à produção de cultura material pelos assentados, como a produção das artes visuais, instrumentos gerados pelos próprios assentados a partir de seus recursos limitados, assim como a disposição de construções e outras fontes;

4. reconhecimento em campo da estruturação dos espaços da ocupação do assentamento, a fim de percorrer áreas afastadas de dentro do assentamento e notar diferenças entre as condições das áreas;

5. realização de entrevistas semiestruturadas com assentados das mais diversas origens e papeis sociais, que tenham tido alguma referência notável de participação ou de recusa às experiências associativistas;

6. realização de entrevistas livres e reuniões com agentes sociais externos ao assentamento, que por diferentes maneiras acabam tendo algum meio de intervenção ou comunicação nos domínios do assentamento. Estas foram feitas de forma espontânea diante da relevância atribuída a eles pelos próprios assentados ${ }^{2}$;

${ }^{1}$ Vale observar que o presente estudo faz parte do projeto de pesquisa Fapesp - "Fundamentos da heterogeneidade: análise do desempenho de firmas com dotação inicial semelhante", (2015/09611), de forma a aproximação com a comunidade foi facilitada pela aproximação gradual com os moradores, por meio de aplicação de questionários e roteiros de entrevistas para pesquisa geral.

${ }^{2}$ As entrevistas foram gravadas com a utilização de dois gravadores a fim de se conseguir comparar e dirimir dúvidas oriundas de uma má compreensão dos áudios, além de tentar garantir a não interrupção das entrevistas por conta de problemas técnicos. Foram feitas anotações sobre pontos importantes durante as entrevistas, no sentido de facilitar a esquematização dos dados levantados. 
7. busca de referências em documentos primários a respeito da evolução do assentamento, desde sua fundação legal, até elementos históricos que pudessem se relacionar em alguma medida com a formação e a atual condição do assentamento diante do problema de pesquisa.

O propósito fundamental da realização das entrevistas foi o de identificar as contradições existentes com respeito às percepções relativas às formas de cooperação nas atividades produtivas, sejam formais ou informais, que possam munir o investigador de elementos para a compreensão dessas dinâmicas sociais. Uma vez identificado, tentou-se extrair as informações necessárias para a coleta de maiores informações a respeito da natureza dessas contradições.

Nesse ponto, procurou-se tomar as informações necessárias para o entendimento dos conflitos de interesses possíveis no momento da tomada de decisão da ação coletiva. Da mesma forma, tentou-se compreender as opções possíveis por parte da atuação dos assentados fora das propostas pelos canais formais de atuação, diante da procura por outras formas de organização da produção e da reprodução social.

Antes da ida a campo fez-se uma entrevista teste com um ex-lavrador, externo ao assentamento e que há muito se radicou na cidade, para identificar problemas que poderiam ser recorrentes de acordo com o formato inicial quanto aos problemas do trabalho em pecuária e agricultura de forma mais geral. A partir das respostas que indicavam uma lógica distinta à esperada pela primeira versão, fez-se então a conformação das perguntas propostas no roteiro a fim de conseguir extrair de maneira mais precisa as informações por parte dos assentados conseguindo eximir erros de interpretação da realidade agrícola que poderiam ser expressos nas perguntas.

Aos entrevistados deu-se o livre arbítrio à identificação e a permissão de uso das informações coletadas. Em regra, não houve pedidos ou requisições especiais ou específicas por parte dos entrevistados que não foram previstos e contornados para a realização das entrevistas. O mesmo se deu durante as entrevistas livres que não foram estruturadas.

Ao tocar em temáticas controversas, nas quais as disputas dos agentes sociais extrapolam a disputa das narrativas dos acontecimentos e das atuais dinâmicas —em outras palavras, onde há um embate social real, com interesses de interferência imediata na vida dos entrevistados-, optou-se por manter o anonimato de todos os entrevistados. Por conta desta opção, a apresentação do perfil de cada um dos entrevistados se limitou a caracterizá-lo, de acordo com as categorias relevantes à pesquisa, sem a necessidade de apresentar evidências 
que poderiam identificá-los.

Dentro das possibilidades, tentou-se interferir o mínimo possível na entrevista tentando manter os entrevistados empenhados em fornecer as informações mais confiáveis possíveis. Muitas vezes durante as entrevistas, notou-se, a necessidade de conquistar a cumplicidade dos entrevistados. Momentos extremamente delicados do ponto de vista epistemológico por conta da possível interferência subjetiva ou emocional dos relatos, além da indução imprópria de levar os entrevistados a responder de uma ou outra maneira. Nestes casos, houve a preocupação em criar uma atmosfera de confiança e empatia entre o entrevistado e entrevistador.

Devemos apontar que a elaboração do roteiro da entrevista semiestruturada se baseou em uma observação feita de entrevistas anexas de trabalhos anteriores em temas ligados ao problema de pesquisa em questão, tomando algumas questões e adaptando-as ao problema em questão. Dentre esses autores, dos quais se tomou contato, está Pedro Ivan Christoffoli, em seu trabalho de dissertação de mestrado O Desenvolvimento de Cooperativas de Produção Coletiva de Trabalhadores Rurais no Capitalismo: Limites e Possibilidades, de 2000, pela Universidade Federal do Paraná em Curitiba.

No total, foram realizadas 12 entrevistas que envolveram em seu total 14 entrevistados, totalizando 31 horas e 30 minutos de gravações. Algumas das entrevistas acabaram sendo feitas em mais de uma oportunidade, dada a impossibilidade de seu prosseguimento até o final do roteiro. Foram 9 entrevistas com assentados e 3 com os agentes externos

Dentre o grupo dos assentados, fez-se ao menos uma entrevista de assentado de cada agrovila do assentamento. Uma das preocupações foi identificar associações recentes, assim como arranjos informais de formas de organização da produção.

As entrevistas são compostas por:

Agrovila 1 - Assentado aposentado, desde a fundação;

Agrovila 2 - Assentado produtor, desde a fundação;

Agrovila 2 - Assentado produtor, desde a fundação;

Agrovila 3 - Assentado produtor, desde a fundação; dirigente de cooperativa;

Agrovila 3 - Assentado produtor, filho de assentado;

Agrovila 3 - Assentado produtor, estabelecido posteriormente;

Agrovila 3 - Assentado funcionário de cooperativa;

Agrovila 4 - Assentado produtor, dirigente da cooperativa; 
Agrovila 5 - Assentado produtor, desde a expansão à área.

A Agrovila 6 foi, a princípio, a única agrovila em que não foram realizadas entrevistas por se tratar de uma área de assentamento que não constitui um espaço contínuo, sendo dividida em três áreas separadas.

No entanto, durante a estadia descobriu-se que havia outras agrovilas, não relatadas pelos dirigentes do assentamento, ou mesmo observadas em outros trabalhos. Acontece com elas o mesmo relatado com a Agrovila 6. São elas: Agrovila João Moreira, Agrovila 13 de Maio e a Agrovila 7. Relatou-se o estabelecimento das três há no mínimo quatro anos.

Estas estariam incorporadas nos espaços das outras agrovilas, com uma população difusa e que não teriam um núcleo organizador ou um movimento diretamente associado. Entretanto, ao contrário da Agrovila 6, não foram encontrados trabalhos ou documentos precedentes a essa pesquisa que implicassem na discussão da implementação dessas áreas ligadas ao assentamento.

Podem-se fazer algumas suposições sobre a criação de agrovilas dentro das já existentes, questão que será tratada na análise dos resultados. Entretanto, pode-se pensar que há algum tipo de disputa na relação que envolve o reconhecimento desses agrupamentos como sendo agrovilas distintas e os grupos de interesse das agrovilas já estabelecidas.

Quanto ao tema dos agentes externos entrevistados, foram realizadas entrevistas com três deles. Nelas, procurou-se compreender a perspectiva dos problemas de uma intervenção, dado que os agentes estão na posição de um investigador que é igualmente externo à comunidade.

A primeira foi realizada com um agente do Sindicato Rural responsável pela atuação em extensão técnica com produtores rurais. No caso do assentamento, ele é o responsável por alguns cursos referentes a inovações na produção. A segunda foi com um agente de uma Organização atuante no Assentamento, testemunha da própria fundação do assentamento, que mantém sua atuação no assentamento até os dias atuais. Ainda que esteja ligado a organizações atuantes no assentamento, fala apenas em seu nome, não representando, de maneira alguma, a organização à qual essa testemunha pertence. Por fim, a terceira foi com um agrônomo vinculado ao ITESP (Instituto de Terras do Estado de São Paulo), órgão responsável pela concessão do assentamento. Porém, além da sua própria posição institucional, ele mantém uma atuação relevante na área, envolvendo-se diretamente com a comunidade.

Em todas as entrevistas, semiestruturadas ou livres, procurou-se levantar elementos da 
história de vida de cada um dos entrevistados, para que pudessem ser cotejados diante de outras informações de diferentes naturezas. Com isso, a observação etnográfica passava a ser apurada com o emprego da atenção do investigador a outras áreas.

Cabe registrar que houve constrangimentos em relação à gravação das entrevistas diante das informações que poderiam ser coletadas. Assim, procurou-se manter tanto o anonimato como a tomada do registro do fato por outros meios que não o da gravação. Nos casos em que esse constrangimento ocorreu no momento da realização da entrevista, os registros das informações coletadas foram feitos por meio da tomada de anotações.

Realizado o trabalho de levantamento de dados no campo, continua-se um trabalho processual e ininterrupto de averiguação das bibliografias existentes a respeito do campo, assim como dos trabalhos feitos sobre a agricultura familiar, reforma agrária, cooperação agrícola e outros ligados à economia institucional e à economia das organizações. Quanto a isso, observa-se que há uma tendência da produção dos trabalhos acadêmicos em concentrarse em temas correlatos aos dos problemas econômicos da cooperação.

\subsubsection{Triangulação dos dados}

A origem do conceito de triangulação dos dados é atribuída a diferentes atividades, como Stake atribui à navegação, numa técnica que consiste no estabelecimento de três estrelas no céu para a localização. Contudo, Zappelini e Feuerschütte (2015) colocam que, para o autor, a transposição desse termo para se dirigir a um método não necessariamente se faz com a finalidade de localizar o investigador em um determinado debate ou problema científico. $\mathrm{O}$ que existe na verdade é uma procura por significados para as conclusões em um estudo de caso (Zappellini \& Feuerschütte, 2015) $\square$.

Elas citam que a origem do conceito para outros autores, como Flick (2009), viria da agrimensura, e da Geodésia, como uma maneira de localizar ao indivíduo, a partir de dois pontos conhecidos, a posição de um terceiro ponto ou posição. Dessa forma, a ideia localizar o investigador retorna, considerando que há um determinado lugar dentro do espectro científico onde se pode delinear o conhecimento da pesquisa deste investigador.

Nesse sentido, a triangulação dos dados de diferentes naturezas se trata de uma alternativa para a validação científica de pesquisas qualitativas. Assim, considera-se que, diante dos procedimentos feitos para o levantamento de dados em campo - com a realização de observação, entrevistas, juntamente aos levantamentos bibliográfico e teórico一, a técnica 
de triangulação dos dados seja a mais adequada para a análise deles, tendo em vista a complexidade social dos fenômenos associativistas.

Com isso, faz-se uso de diferentes métodos de coleta de dados, mas também de dados de diferentes naturezas, assim como da pesquisa levada pelos membros do grupo, porém, diferentemente do que é admitido por Creswell e Plano Clark (2013) como uma alternativa da triangulação de dados a partir de uma conjugação de pesquisas tanto qualitativa como quantitativa. Dessa maneira, aqui os dados de diferentes naturezas são limitados à pesquisa qualitativa, podendo abarcar resultados obtidos por dados da pesquisa quantitativa (Creswell \& Plano Clark, 2013).

A técnica da triangulação dos dados é amplamente usada em estudos de administração no Brasil. Porém, seu uso frequentemente ocorre de forma inconsciente ou não acaba sendo assim referido pelos próprios pesquisadores (Zappellini \& Feuerschütte, 2015).

Muitos trabalhos no Brasil reproduzem a técnica, o que demonstra que a triangulação dos dados é um passo inicial comum requisitado pela própria natureza das pesquisas qualitativas e que, por isso, há uma necessidade de validação destas por meio da apropriação de dados de naturezas distintas para o empreendimento dessas pesquisas. Reconhece-se, dessa maneira, que essa necessidade foi constatada nesta pesquisa (Zappellini \& Feuerschütte, 2015).

Assim, os dados que correspondem à triangulação feita aqui são a bibliografia existente, os dados da observação com os resultados da aplicação dos questionários e as entrevistas semiestruturadas. Porém, como observado por Flick (2009), a triangulação dos dados se justifica pela necessidade de superação do âmbito individual da pesquisa, tendo em vista que o estudo de um fenômeno, como no caso um fenômeno social em uma pesquisa qualitativa, exija a apreensão de uma amplitude de conhecimentos dificilmente alcançada por um pesquisador individualmente (Flick, 2009).

Portanto, a ideia de uma triangulação de dados de diferentes naturezas acaba sendo um meio para a compreensão destes e não um fim em si mesmo. Contudo, há dessa maneira a utilização de dois métodos qualitativos somados a uma abordagem quantitativa, esta última a partir de dados extraídos de pesquisas feitas em grupo.

Nesse sentido, o que se constituiu foi uma pesquisa que produziu relatórios diários em campo, memorandos escritos das observações, além das entrevistas e de conversas menos formais com a população dos assentados. Outra dessas fontes é o registro das imagens obtidas em campo, tomando seus determinados momentos e acesso a arquivos pessoais privados sobre alguns dos acontecimentos. 


\section{A ABORDAGEM INSTITUCIONALISTA}

Ao ser introduzido na área de Economia Institucional —mais especificamente em Economia das Organizações - o estudante acaba por se deparar com uma vasta literatura que é oriunda de diferentes disciplinas, a partir de problemas de pesquisa diversos, atentas a outros objetos e, sobretudo, empreendendo trabalhos de natureza epistemológica distintas.

As interpretações entre os autores mais importantes a respeito da conformação da área de estudos em Economia Institucional demonstram não haver consenso algum a respeito de sua caracterização enquanto ciência. Deve-se observar que em diferentes lugares ou centros de pesquisa se atribui uma determinada evolução a esse respeito.

Muitas vezes essas interpretações são absolutamente contraditórias, mesmo que procurem os mesmos parâmetros para o seu amparo científico. A natureza dos trabalhos assim como os métodos para sua execução são os mesmos, inclusive tomando para si os mesmos teóricos a esse respeito.

Porém, ainda que o debate seja feito em âmbito científico, o problema de suas diferentes interpretações é outro. Talvez, e é isso que se supõe para iniciar essa reflexão, a diferença expressa entre as interpretações da realidade feitas por autores tenham uma natureza não científica dentro do próprio âmbito do conhecimento humano. Explicado de outra maneira, a autonomia e busca por elaborar teorias e explicações científicas pelos termos e construtos dos seus próprios autores, acaba por dispersar o debate da comunidade epistêmica atenta aos objetos de estudo em questão, tendo em vista a dificuldade de apropriação de cada uma das contribuições em particular.

Assim, criam-se grupos, coletividades, ou propriamente comunidades epistêmicas que, afastadas entre si, não dialogam e evoluem diferentemente. Grandes pesquisas são empreendidas sem encontrar interlocução com outras comunidades, involucrando-se em seus próprios temas.

Não se propõe aqui empreender um esforço interpretativo da Economia Institucional e de todos os seus autores. Coloca-se aqui a questão de procurar compreender problemas que escapam à ciência para que depois sejam levados em consideração para uma interpretação a respeito do que é o nosso objeto quanto às organizações e instituições.

A seguir, para poder conformar um horizonte teórico, dentro das possibilidades, um panorama da evolução do tema até o momento é apresentado. O objetivo desse exercício 
agora passa a ser o de uma localização dentro do atual cenário científico.

\subsection{A NOVA ECONOMIA INSTITUCIONAL}

Nas principais universidades norte-americanas o trabalho de Douglass C. North causou um grande impacto por conta de sua natureza inovadora aos estudos institucionais nos EUA. Ela passa a ser intitulada de Nova Economia Institucional por diferenciar-se de um debate de natureza institucional heterodoxo, ou de natureza sociológica que a precedeu, como no caso de autores como John Commons.

A ideia geral difundida nos trabalhos que tomam a obra de North é a de que, em economia, "instituições importam". Em outras palavras, o que se compreende aqui é que há um fator não material, extraeconômico que influencia o desempenho econômico de determinadas organizações ou firmas.

No que concerne à compreensão sobre organizações e instituições, a força das ideias de North demonstra ter ainda mais expressão. A definição de que "as instituições são as regras do jogo" e que, a princípio, os jogadores seriam como consequência os agentes ou as organizações em interação, é difundida em diversos trabalhos, seja explicita quanto implicitamente.

A partir dessas primeiras concepções North trata, durante sua obra, de decompor elementos analíticos para categorização desses termos no sentido de configurá-los enquanto conceitos científicos. A esse exemplo, um dos elementos seria o da formalidade ou da informalidade das instituições, ou seria o da racionalidade presente nas interações por meio de modelos mentais, além de diversos outros como o do reforço de uma expectativa via um constrangimento, ou a ideia da cooperação diante da interação.

Em suma, pode-se afirmar que North consegue dotar uma parte da comunidade acadêmica norte-americana de uma concepção institucional que pode ser incorporada pelo debate econômico neoclássico já existente. Com isso, a concepção institucional de North complementa uma fraqueza ou limitação do conhecimento proposto pelos teóricos de então, por adicionar elementos extraeconômicos aos elementos econômicos.

Em um esforço para a compreensão e apreensão de suas ideias, Paulo Gala (2003) expõe os pontos fundamentais, suas transformações e as incorporações feitas nas teorias e nos modelos de North. Com isso, ele localiza as concepções, tendo um recorte teórico no ano de 1981, em que North tece suas considerações sobre o papel do Estado quanto à formação da propriedade e da economia, da concepção da eficiência em sua relação com a economia e com o sistema de propriedade vigente sob tal Estado, mas se preocupa também com a relação entre 
a racionalidade humana e introduz o papel das ideologias na teoria econômica (Gala, 2003) $\square$.

Nesse primeiro período, Gala entende que North, em seu modelo dos anos 1990, introduz em seu pensamento a incerteza, custos de transação, instituições, organizações e, por fim - o mais fundamental—, a dinâmica da matriz institucional. São esses conceitos incorporados nesse segundo momento que fundam uma perspectiva institucional econômica sobre o desenvolvimento de nações ao redor do mundo (Gala, 2003).

Gala ainda entende que North se apropria da ideia de Ronald Coase sobre os custos das transações e amplia seu alcance ao relacioná-las com as instituições, atribuindo a estas um papel de diminuir aquelas. Em outras palavras, as instituições importam, pois quando as transações têm custos, são as instituições que os diminuem. Porém, as instituições teriam um caráter funcional para a diminuição dos custos de transação, dada a incerteza inerente às interações entre os agentes.

Por fim, o autor compreende que North, ao teorizar sobre instituições como regras formais ou informais, como seu conceito central, identifica que as organizações são o fator gerador da mudança institucional. Porém, como observado pelo autor, North apresenta a metáfora sobre os esportes, como no caso das organizações serem os "jogadores" e as instituições serem as "regras do jogo", como ele aponta:

\begin{abstract}
A nova economia institucional é uma tentativa de incorporar uma teoria das instituições na economia. No entanto, em contraste com as muitas tentativas anteriores de revogar ou substituir a teoria neoclássica, a nova economia institucional se baseia, modifica e amplia a teoria neoclássica para permitir que ela atenda e lide toda uma série de questões até agora além do alcance de seu conhecimento. O que ela mantém e avança é o pressuposto fundamental da escassez e, portanto, da concorrência - a base da abordagem teórica de escolha que está subjacente à microeconomia. $\mathrm{O}$ que ela abandona é a racionalidade instrumental - $\mathrm{a}$ assunção da economia neoclássica que a tornou uma teoria livre de instituição. (North, 1993, p.1).
\end{abstract}

Nesse sentido, North, mais do que uma simples teoria, inaugura um legado dentro do debate econômico neoclássico. Segundo o próprio North:

The new institutional economics is an attempt to incorporate a theory of institutions into economics. However in contrast to the many earlier attempts to overturn or replace neo-classical theory, the new institutional economics builds on, modifies, and extends neo-classical theory to permit it to come to grips and deal with an entire range of issues heretofore beyond its ken. What it retains and builds on is the fundamental assumption of scarcity and hence competition--the basis of the choice theoretic approach that underlies micro-economics. What it abandons is instrumental rationality--the assumption of neo-classical economics that has made it an institution-free theory (North, 2003, p. 1). 
Gala, por fim, expõe os elementos retóricos, de inspiração neoclássica na teoria de Douglass C. North em sua dissertação de mestrado apresentada na FGV. Para Gala, além de North construir, para além da teoria, um esforço retórico para persuadir leitores, segundo ele, de perfil neoclássico, North também incorporaria elementos de inspiração marxista não explicitamente expressos em sua obra por conta da sua preocupação com a repulsa a esta inspiração por seus leitores (Gala, 2001). Basicamente, essa postura retórica é expressa aqui:

Já no primeiro capítulo, North apresenta suas ideias se referindo explicitamente à teoria neoclássica (North 1990, pg.3). E é fato que o autor também se diz preocupado com a leitura do público não economista, principalmente de cientistas sociais (North 1990, p.viii). Também, por momentos, North "conversa" com a teoria marxista e com historiadores em geral. Mas o núcleo de sua obra direciona-se primordialmente para a "current economic theory" e "cliometric history", em seus próprios termos.

Boa prova dessa postura encontra-se na análise do capítulo 2. O autor gasta seis páginas para analisar e resenhar o que havia de mais recente em teoria dos jogos por que não resenhar a teoria marxista? - para depois concluir que nenhuma destas empreitadas havia trazido grandes avanços. Ora, se estas teorias não apresentaram resultados tão promissores, por que então apresentá-las, senão como uma maneira de convencer o leitor - neoclássico - a respeito disso? A partir de uma leitura mais atenta, podemos identificar o cuidado do autor em conversar com o leitor a respeito de uma teoria que será ainda apresentada. Sempre levando em consideração prós e contras e analisando alternativas, North procura mostrar a relevância de sua proposta.

Apesar desse movimento insistente de conciliação, percebemos, ao longo do livro, que a complementaridade entre a teoria de North e a escola neoclássica, é no mínimo, controversa. Sem nos aprofundar muito, podemos citar dois dos principais pilares do pensamento de North que podem ir contra a teoria neoclássica - tomando por base a definição de Mario Possas. (1997, p.15; 34) (Gala, 2001, p. 50).

A esse respeito, David Dequech expõe esses diversos problemas conceituais existentes em um debate que passa pela aceitação de comunidades diferentes entre os próprios economistas. O domínio de uma determinada teoria ou tese e o seu desafio passam por uma questão fundamental que nos leva a entender fatores sociológicos como a premiação por parte de alguns economistas e sua receptividade em alguns meios epistêmicos (Dequech, 2007).

Não parece ser a primeira vez que se nota um impasse epistemológico no estudo das organizações. A questão da superação do desafio das organizações e dos estudos precedentes, 
não apenas em relação à economia, administração e a racionalidade, mas também em relação a uma postura crítica a isso pode ser retomada.

Tomemos aqui o exemplo de dois autores brasileiros que, dentro da nossa própria comunidade epistêmica, acabaram por deixar notáveis contribuições: Alberto Guerreiro Ramos e Leônidas Hegenberg.

Alberto Guerreiro Ramos foi responsável pela formação de grande parte do pensamento nacional a respeito dos estudos das organizações. Com uma formação qualificada nas disciplinas sociais, sobretudo direito e sociologia, Guerreiro Ramos foi professor universitário com grande atuação pública, chegando a ser deputado federal.

Porém, com os eventos políticos no Brasil de 1964, Guerreiro Ramos acaba por se exilar e, posteriormente, se radicar nos EUA. Foi um dos primeiros e mais notáveis professores brasileiros em universidades americanas, além de ter conseguido cercar-se de interlocutores de grande reconhecimento teórico.

Diante de sua vasta obra, este trabalho optou por retomar suas reflexões científicas sobre seu momento vivendo já nos EUA, onde tomou contato com o ambiente que hoje se tornou dominante no debate científico em grande parte da comunidade epistêmica anglófona. Suas contribuições teóricas em organizações se enquadram dentro do campo das teorias críticas das organizações.

É, então, do período de radicação nos EUA que resulta sua obra mais importante no estudo das organizações que, intitulada A Nova Ciência das Organizações, foi publicada originalmente em inglês pela Universidade de Toronto. Nela, Guerreiro Ramos apresenta a sua perspectiva crítica a respeito da própria evolução da ciência da administração e da economia nos EUA e no mundo:

Do ponto de vista dos critérios comparativos dessas tendências de pensamento, tais como, por exemplo, variáveis de padrão e estágios de desenvolvimento, as diferentes sociedades do mundo contemporâneo estão classificadas em fila indiana, apontando na direção da chamada sociedade avançada, ou esclarecida. $\mathrm{Na}$ realidade, tais critérios são armadilhas epistemológicas e ideologias disfarçadas, que fomentam uma errada compreensão dessas sociedades e que as desviam de seu imperativo crítico de auto-reconstrução. As políticas emanadas desses critérios funcionam, na prática, na escalada da ocidentalização do mundo todo. Um dos resultados desse processo, em que estão presas as chamadas nações do Terceiro Mundo, é a degradação de suas estruturas internas. O sentimento de privação relativa, que contamina de modo especial os setores intermediários dessas nações, é um dos fatores primordiais a lhes dificultar a auto-reconstrução. A solução do problema criado por tal sentimento é conceituada por via da categoria serializada do desenvolvimentismo, em sua interpretação padronizada, ou na interpretação marxista. Essa mentalidade adventista, mais do que a escassez de recursos, constitui o obstáculo fundamental à auto-articulação cultural, política e econômica dessas nações. Para poderem superar essa cilada, torna-se imperativa a ruptura com a 
ideologia social do Ocidente (Ramos, 1989, p. 41). $\square$

O objetivo de Guerreiro Ramos nesse livro é contrapor-se ao modelo de análise de sistemas sociais centrado no mercado. Para isso, apresenta um ferramental intelectual e teórico devido ao qual se faz necessária a observação para a inauguração de uma nova ciência das organizações que contém em si um sistema de múltiplos centros. Ele defende que a análise centrada no sistema de mercado é válida apenas para um tipo específico de organização da vida associada humana. Para ele, a evolução da produção científica em organizações centrada no mercado atualmente dificulta a compreensão de problemas da sociedade e de sua superação, pois esse modelo não aceita seu caráter funcional de produção de conhecimento.

$\mathrm{Na}$ compreensão dos significados formais, legais, substantivos ou intrínsecos dos termos econômicos, Ramos aponta para o fato de que o problema econômico e a atribuição do seu termo para designar outros arranjos sociais não se encerram em si. É a incompreensão de uma lógica social da vida articulada que acaba, por fim, por demonstrar que o problema econômico não é intrínseco a um sistema de mercados, como defende aqui, ao resgatar Karl Polanyi:

\begin{abstract}
Polanyi indica que, nas sociedades não mercantis, as economias existiam no sentido substantivo. Na sociedade de mercado, porém, o termo econômico deriva formalmente seu sentido do pressuposto de que, sendo escassos os meios e os recursos, estes devem ser otimizados através de opções que atendam, com precisão, aos requisitos de economicidade. Nas sociedades não mercantis, a escassez de meios não constitui princípio formal para a organização da produção e para a escolha humana de modo geral, uma vez que a sobrevivência do indivíduo é, normalmente, garantida pela eficácia dos critérios sociais globais (não da organização formal) de reciprocidade, redistribuição e troca. A economia, aqui, está incrustada na tessitura social, e não constitui um sistema auto-regulado. Em outras palavras, numa sociedade não mercantil, ninguém vive sob a ameaça do chicote econômico.

Por circunstâncias idênticas às que foram mencionadas, nas sociedades não mercantis as organizações constituem, de modo geral, campos de experiência de que ninguém tem formalmente experiência. Em tais sociedades, os indivíduos têm uma vida compacta, não uma vida diferenciada. Em outras palavras, existem bases substantivas e não formais, legais ou contratuais. Por exemplo, numa sociedade primitiva uma família é uma organização substantiva, no sentido de que não funcionaria como um sistema a menos que existisse algum padrão nos relacionamentos entre aqueles que a constituem, e entre estes e o ambiente exterior. A família em nossa sociedade, na medida em que ainda preserva algumas funções da família arcaica, partilha de seu caráter organizacional substantivo. No entanto, graças à natureza da sociedade global contemporânea, a família está antes se transformando num fenômeno de organização formal. (Ramos, 1989, p. 124).
\end{abstract}

Ao elencar a questão da racionalidade e de sua crítica, Guerreiro Ramos aponta para o fato de que ela é tomada e reproduzida pelos autores dos estudos sobre as organizações de forma que esta acaba sendo tomada como um cálculo utilitário de consequências, como sendo essa a operação lógica e fundamental da relação entre os fins e os recursos dotados. É a partir 
disso que a racionalidade é concebida e utilizada pelos teóricos em economia.

Com esse exemplo, Guerreiro Ramos supera os conceitos das racionalidades, como o da corrente de Simon, que considera o indivíduo um operador de cálculo utilitário, ou o da corrente da racionalidade humanista, assim como o de Chris Argyris, também considerado por ele como um "anti-simonista":

É óbvio que os simonistas, assim como seus críticos humanistas, falham em compreender a questão da racionalidade. Até que emergisse a sociedade de mercado, o tipo de raciocínio deliberado, somente interessado nos meios de atingir metas determinadas, fora apenas um aspecto limitado de um conceito mais amplo de racionalidade. Como está explicado em outra parte deste livro, o conceito de racionalidade. Não há uma só ocasião, em seu livro, em que ele indique, explicitamente, os limites entre os quais o conceito tem validade. Tivesse ele esclarecido que sua opinião era válida apenas no mundo de puros objetivos econômicos e a posição que adotou seria mais firme. Infelizmente, não chega a fazer tal esclarecimento e, na realidade, tenta induzir o leitor a acreditar que seu enforque envolve tudo aquilo que se pode considerar como racionalidade. Por exemplo, questiona o conceito de racionalidade de Aristóteles que envolve o exame da 'bondade' do homem e da sociedade e o considera 'limitado' (Simon, 1965, p.47), como se ele e o filósofo grego estivessem tratando da mesma dimensão de racionalidade.

A verdade é que o termo racionalidade, como é usado por Simon, nada absolutamente tem a ver com o conceito aristotélico de racionalidade. Aristóteles jamais considerou o mercado como sistema primordial da sociedade e nunca pensou que os requisitos psicológicos do mercado se transformassem nas normas da vida social em seu conjunto. É certo que tinha clara noção da racionalidade do comportamento econômico, mas em seu conceito normativo de uma boa sociedade esse tipo de racionalidade só incidentalmente influiria sobre a existência humana. Poder-se-ia argumentar que o conceito aristotélico de prudência contém um ingrediente de cálculo. No entanto, na opinião de Aristóteles, a prudência é uma categoria ética, não puramente uma conduta conveniente. Assim, diz o filósofo: 'Não podemos ser prudentes sem sermos bons' (Ética a Nicômano, VI/XIII, p.10). Consequentemente, a racionalidade aristotélica e a racionalidade instrumental pertencem a duas esferas qualitativas da existência humana, e a racionalidade de Aristóteles não pode ser criticada da perspectiva de Simon, a menos que o autor de Administrative Behavior queira, realmente, dizer que a racionalidade instrumental é a única que se pode conceber, o que é uma posição claramente errada. (Ramos, 1989, p. 122-123).

Com isso, observa-se que a profundidade do caráter crítico de Guerreiro Ramos diante da evolução da teoria social à sua época é evidente. Porém, ainda que se possa atribuir a inacessibilidade à obra de Guerreiro Ramos durante os anos 1980, críticas concomitantes ao que se apresentava nos trabalhos de âmbito acadêmico apontam para os mesmos pontos em questão. Isso demonstra que a incorporação teórica feita a partir da difusão das novas teorias tinha resistência.

Uma dessas vozes foi a de Leônidas Hegenberg, pioneiro dos estudos de lógica no Brasil. Ao observar o estado da arte nos estudos em economia, sobretudo nos que se referiam à teoria das firmas e à apropriação da racionalidade por meio do individualismo 
metodológico, Hegenberg acaba por apresentar o artigo Notas Metodológicas Sobre a Ciência Econômica no XII Encontro da Associação Nacional de Centros de Pós-Graduação em Economia (Anpec) em 1984, publicado no ano seguinte.

Hegenberg aponta que, diante de um determinado problema ou fato, os sujeitos, ao interagirem para o entendimento deste, acabam criando um canal de comunicação que é dado por um vocabulário básico, o VB. A partir de seu uso, incorporam a ele novos vocábulos e termos, estabelecendo assim um conjunto estável de significados (Hegenberg, 1985) $\square$.

À medida que esse vocabulário básico passa a ganhar complexidade, ao ser confrontado por evidências de que sua veracidade científica pode ser colocada em questão, o que se observa então é a formação de um determinado escopo dessa atuação:

\begin{abstract}
As leis simplificam a tarefa de efetuar o ajuste do homem ao seu contorno, exemplificando por que certos atributos se manifestam e por que certas relações são de se esperar. As leis fixam, com certa precisão os significados das palavras de VB. Há um 'jogo' entre termos e leis, conduzindo a uma apreciável quantidade de generalizações. Estas acabam formando uma 'pauta de referência', reunindo e organizando conhecimentos: a circunstância está interpretada e nela é viável a ação para a consecução de objetivos compatíveis com a vida almejada. (Hegenberg, p.2).
\end{abstract}

Assim, ao rearticulá-los e retomar suas proposições iniciais, o que acaba ocorrendo é que o vocabulário básico, ao ser incorporado por essa determinada coletividade, passa então a evoluir no sentido com conformar um vocabulário teórico, ou VT. O autor aponta o fato de que esse vocabulário teórico passa então a ser incorporado em teorias com um nível de complexidade ainda maior, em um movimento de afastamento do real, adequando esse sistema novo a um quadro de explicações e previsões cada vez mais amplo.

As "boas" teorias assentam-se, em regra, em uma coleção de termos primitivos (isto é, não definidos nessa teoria) e uma coleção de axiomas (isto é, sentenças acolhidas, nessa teoria, sem maiores discussões). Novos termos são introduzidos, mediante adequadas definições. Dos axiomas, com auxílio da lógica, são, a seguir, deduzidos os teoremas da teoria.

A seleção de termos primitivos e axiomas é feita de maneira a permitir que aqueles resultados "importantes" ou "interessantes" (relativos aos objetos focalizados) apareçam nos teoremas da teoria.

Teoremas não são, a rigor, "novos", por um prisma lógico. Podem, contudo, mostrar-se epistemologicamente "novos", revelando "fatos" até então desconsiderados. Desenvolvendo-se, a teoria dá lugar a uma quantidade apreciável de teoremas. Amplifica- se o VT e se amplia o número de consequências passíveis de confronto com o real.

Lentamente, sistematizando resultados "aceitáveis", a teoria se "equilibra". Explica e permite previsões. Toma-se admissível e, talvez, satisfatória. (Hegenberg, 1985, p. 209).

É partindo dessa consideração sobre o que ocorre na ciência em geral que Hegenberg 
defende que essa forma de progressão da produção de conhecimentos é obscurecida. O que ele observa é que há uma inadequação do seu trabalho com seus propósitos:

\begin{abstract}
A inexistência de refutações não estabelece a verdade dos pressupostos, mas autoriza mantê-los na condição de hipóteses aceitáveis, sujeitas a ulteriores corroborações. A teoria não refutada é mais amplamente explorada, com o fito de saber até que ponto engloba resultados de interesse, colocando-os num "todo" organizado. Muitas opções podem apresentar-se -e várias teorias alternativas se formulam. Preferir esta ou aquela é algo que depende, provavelmente, de fatores como "simplicidade", "poder explicativo", "cogência" (adequação ao real), e assim por diante. (Hegenberg, 1985, p.209).
\end{abstract}

Finalmente, Hegenberg considera que a evolução da ciência em seu tempo acaba por demonstrar a sua inconformidade com a sua limitação real. A busca por alçar a economia à ciência apropriada a outro tipo de conhecimento levou-a ao isolamento de questões primordiais a ela própria:

\begin{abstract}
Ainda assim, os economistas procuram delimitar um conjunto de problemas principais, para equacioná-los de maneira conveniente. Isso redundou em notáveis avanços e sua área de estudos tornou-se, de fato, aos olhos de leigos e de pesquisadores, uma das mais importantes ciências sociais — de grande significado, de alta complexidade técnica, de muita sofisticação matemática e largo emprego de métodos quantitativos e, a par disso, de apreciável fertilidade. Esse progresso devese, em parte, ao fato de se haver procurado "isolar" a economia, deixando de lado inúmeras questões sociais, políticas, psicológicas, jurídicas e religiosas que, até há pouco, se mesclavam às econômicas propriamente ditas. (Hegenberg, 1985, p. 211).
\end{abstract}

É somente após observar a questão da produção científica como um todo que Hegenberg focaliza sua análise especificamente na ciência em economia e, mais precisamente, toma o exemplo da teoria das firmas. $\mathrm{O}$ autor assume os pressupostos da formulação teórica desta como sendo dados pelo seguinte:

A microeconomia desenvolveu-se com o objetivo de explicar o comportamento econômico. Os trabalhos clássicos de Adam Smith e de Alfred Marshall culminaram com os estudos de E.H. Chamberlin. Neles se delineia o chamado "programa neoclássico do determinismo situacional". Esse programa baseia-se em alguns princípios gerais, como, digamos: 1. O enfoque é individualista: fenômenos do comportamento do mercado são explicados em termos de ações individuais de agentes humanos que atuam em uma situação social. 2. As escolhas individuais de agentes estão de tal modo limitadas pela situação, que apenas um mínimo de pressupostos psicológicos é requerido para explicar tais escolhas. 3. O comportamento está orientado por um "princípio de racionalidade", isto é, as ações decorrem de uma "lógica da situação". Aplicados ao caso das firmas, esses princípios gerais convergiram para alguns pressupostos que se tomaram "núcleo" da teoria neoclássica das firmas. Fazem parte desse "núcleo": a) a maximização dos lucros; b) o conhecimento perfeito da situação; c) as decisões independentes; d) o mercado perfeito. (Hegenberg, 1985, p. 212-213).

Partindo dessa análise, o autor submete as proposições a testes de validez e acaba por 
desconstruí-las uma a uma. A teoria das firmas pensada para esses fins, pura e simplesmente, é impraticável enquanto ciência, segundo o autor.

Com isso, Hegenberg coloca que, todo o ímpeto em salvar epistemologicamente um campo dos estudos em economia, em função dessas premissas neoclássicas, acaba inviável —não por ser em si desprezível, pois Hegenberg não ignora os avanços feitos a esse sentido na economia, mas sim por sua pretensão em ser um conhecimento inadequado à sua própria produção enquanto uma ciência dura ou natural.

Entretanto, ainda que os estudos sobre economia institucional tenham evoluído em parte, como descrito por Guerreiro Ramos e Hegenberg, continua havendo controvérsias e debates em meio a esse campo. Entre os autores do atual cenário está Geoffrey Hodgson, que mais recentemente trata das questões por um viés semelhante, fazendo contribuições de propósito lógico e localizando o problema da produção científica ao tratar de instituições em economia.

Porém, é necessário aqui compreender a relação entre Hodgson e a Nova Economia Institucional. É nesse sentido, então, o valor da apreciação a essa evolução teórica feita por André Simões. O autor expõe as diferenças existentes entre a Nova Economia Institucional e o neoinstitucionalismo, além de propor, a partir dos conceitos deste, uma análise sobre o desenvolvimento do caso sul-coreano. O autor apresenta Douglass C. North como um representante da Nova Economia Institucional e Geoffrey Hodgson como um representante do neoinstitucionalismo (Simões, 2014) $\square$.

Simões aproxima o pensamento de North ao instrumental teórico ortodoxo, apresentando uma crítica ao pensamento ortodoxo em economia, do qual este era capaz de ser apropriar e assim absorver suas atribuições institucionais. No entanto, levanta uma crítica feita por Daron Acemoglu e James Robinson que, apesar de terem empreendido estudos a partir da teoria de North, acabam destacando que a relação entre as concepções da Nova Economia Institucional de Douglass C. North e o desenvolvimento econômico de países não poderia ser afirmada, pois não se tem um conjunto de conhecimentos científicos de outra natureza que corrobore essa relação tal qual a da sua concepção:

Ao contrário de North, que construiu uma teoria que procura explicar as transformações no desenvolvimento dos países a partir de mudanças institucionais, Acemoglu e Robinson afirmam ser difícil explicar esse processo a partir do estado do conhecimento científico atual. A razão para isso encontra-se na impossibilidade de transformar as trajetórias de desenvolvimento dos países unicamente pela mudança nas instituições econômicas. É preciso, igualmente, que mudanças sejam feitas nas instituições políticas, o que, por sua vez, desloca o eixo de análise para questões que envolvem a disputa pelo poder político numa sociedade. (Simões, 2014, p. 43-44). 
É a partir dessa concepção ampla e dessa atribuição crítica feita pelos próprios autores que replicaram a análise desse modelo teórico a quase todos os países do globo que se deve aqui orientar uma perspectiva crítica à sua análise, como a que, no caso, o autor atribui a Geoffrey Hodgson. O ponto de divergência fundamental é o suposto da NEI de que o indivíduo é autointeressado e que seria ele que modelaria as instituições e suas mudanças (Simões, 2014).

A suposição do interesse individual acabaria sendo o elemento que embasaria as críticas da NEI à organização do Estado, já que este seria composto de indivíduos igualmente autointeressados, não representando ou cumprindo o seu papel público. Assim, a ideia de que o individualismo dos agentes sociais é o que corresponde a um sentido de transformação institucional que se baseia nele.

Em contraponto à visão da NEI, os neoinstitucionalistas compreendem que as instituições, na verdade, resultam de uma interação de um mundo pré-existente com o indivíduo que a ele se incorpora. Essa seria, portanto, a base da gênese das instituições nessa relação entre as instituições e os indivíduos, não em um sentido único, mas sim numa condição em que não se descarta o sentido oposto de mudança: tanto os indivíduos mudam as instituições, como elas também mudam os indivíduos:

\begin{abstract}
A partir dessa constatação, embora toda mudança de hábitos individuais influencie a mudança institucional, esses hábitos já são previamente condicionados pelas instituições, que, por definição, precedem os indivíduos. Assim, tem-se um caminho duplo, com indivíduos e instituições exercendo influências uns sobre os outros, mas com a primazia das últimas sobre os primeiros. Essa via de "mão dupla" fornece importantes elementos para explicar o desenvolvimento econômico a partir da perspectiva neoinstitucionalista. Em primeiro lugar, porque não considera, como os economistas neoclássicos, que o autointeresse seja a motivação básica dos indivíduos. De forma contrária, essa motivação pode ser múltipla (inclusive autocentrada) e tem como característica básica a maleabilidade, ou seja, a capacidade de ser modificada, pois está sujeita aos condicionamentos institucionais. Em outras palavras, as mudanças institucionais podem levar a transformações na motivação dos indivíduos. (Simões, 2014, p. 47).
\end{abstract}

Dadas essas observações, cabe aqui observar que este não se trata de um estudo que se detenha as relações entre instituições e indivíduos, mas entre as organizações e o fenômeno da cooperação. Com isso, deve-se aqui atentar às concepções sobre as estruturas de governança.

A partir da concepção coseana de custos de transação, Oliver Williamson (1996) propõe serem as estruturas de governança formatadas pelo objetivo de minimizá-los. Porém, os mecanismos para tal é que haja uma relação entre os três níveis envolvidos: o ambiente institucional, as estruturas de governança e os indivíduos. 
Entretanto, é Oliver Williamson que trata da teorização sobre as estruturas de governança em relação com as firmas. Para ele, as estruturas de governança são geradas a partir da interação entre o indivíduo e o ambiente institucional e que, enquanto tal, tem a relação com a redução dos custos de transação.

Tanto a aplicação, quanto a relação entre os mecanismos da formação da estrutura de governança acabam por endereçar um caminho entre a relação entre os agentes dentro da firma a partir da transação como unidade de análise. Assim, Williamson reconhece que há três tipos de relações entre esses agentes: as hierárquicas, as de mercado e, por fim, as de contrato.

Nesse sentido, o objetivo da configuração desses arranjos para os agentes sociais é o de reduzir custos de transação. Ou seja, na relação entre dois agentes econômicos, compreendida por meio dessas categorias, o que se depreende é que a decisão em torno às transações não teria outros constrangimentos, levando-nos a questionar o papel que Williamson atribui à racionalidade nas decisões destes agentes.

Contudo, observamos que, no interior de organizações específicas, a lógica de formação de grupos dirigentes não exclui a esfera de disputas com interesses extraeconômicos, que também exercem influência na transação. Oliver Williamson invoca a concepção de Robert Michels sobre o oportunismo e a democracia dentro das estruturas de governança nas organizações, diante da atuação autointeressada das oligarquias.

Ainda que Williamson tente retratar as concepções de poder mais relevantes já propostas por economistas, o que nos parece aqui é que seu esforço em purificar economicamente o seu escopo teórico é, por princípio, inviável. A ideia é de que a eficiência possa explicar as dinâmicas existentes nas estruturas de governança e, por conta da competição resolvida a seu critério, ele próprio reconhece que diferentes dotações de recursos proporcionam diferentes possibilidades de ação entre esses agentes e que, dessa maneira, o que se pode considerar é que há, portanto, por parte de Williamson, uma incompreensão entre o poder enquanto uma dotação em si que um ou outro ator social dispõe e o poder como um exercício social por conta de uma dotação real, instrumental.

A questão do poder, como vista pelos teóricos da nova economia institucional a partir da visão williamsoniana, acaba compreendendo —ou reduzindo- o exercício do poder como uma relação concorrencial entre as organizações, assim como se opera uma relação de mercado. Williamson trata da questão a partir da seguinte atribuição: 
relatively farsighted way. Since that varies with the circumstances, the argument is that power has relatively less to offer to the study of capital and intermediate product markets, has more bearing on labor and final product markets, and is especially relevant to politics. Even with respect to this last, however, power plays a much more limited role than is widely believed (Williamson, 1996, p.23).

Nesse sentido, o único elemento de poder suposto no pensamento de Williamson é o de que a ação coletiva só tem o sentido de reconfigurar os elementos centrados na interação dentro do mercado, não havendo, então, um espaço social em que esses atores estão inseridos. Exatamente aqui cabe a crítica de Guerreiro Ramos sobre a ideia de que todo o conhecimento das teorias econômicas, ao focalizar o mercado, acaba deixando de lado problemas distintos.

Porém, ao tentar compreender o problema do poder de todo o contrário, Mancur Olson (2002) expõe outra perspectiva a respeito do problema da questão da mobilização e da ação coletiva enquanto uma lógica, enquanto grupos e organizações. É através do uso da ação coletiva enquanto um instrumento que se configuram os grupos de pressão e interesse que conformam a mudança institucional.

Para Olson, a ideia do autointeresse dos indivíduos não pode ser assim, aplicada à lógica da ação em grupos. Nesse ponto, ele compreende que a relação, ainda que contenha um determinado tipo de interesse individual, não impede as condições para tal ação ser compreendida.

Ao propor uma teoria que compreenda todo tipo de organização, independentemente de qualquer atributo que a conforme, Olson acaba o tendo que compreender organizações dos mais diversos tipos. Assim se estabelecem também não só diferenças quanto ao tamanho das organizações, como também à caracterização de seus componentes, e às finalidades de suas atividades.

Olson compreende que, ao contrário de um senso comum, grupos não são necessariamente formados por indivíduos autointeressados imbuídos de um objetivo comum. Tampouco, se fossem dotados de interesses semelhantes, seria necessariamente o caso de agirem conjuntamente.

Sendo assim, Olson compreende que eles agem conjuntamente por influência de algum fator no caso de algum tipo de pressão, ameaça, sanção ou coerção. Dessa maneira, Olson entende que, para que haja organizações que consigam exercer esse poder de influência, é necessário que os grupos que possam fazê-lo sejam pequenos ou minoritários, a fim de que seja mais provável o alinhamento da sua coordenação e de seus interesses. Essa concepção o aproxima da ideia de "oligarquia" de Robert Michels, como invocada por Williamson. 
Nesse sentido, Olson se preocupa com os fatores que possam garantir a manutenção dos membros do grupo com a perspectiva sobre qual seria a real formação da organização, proporcionar mecanismos para a realização da ação coletiva. $\mathrm{O}$ arranjo por meio de interesses específicos acaba sendo um aspecto fundamental da ação coletiva que como tal, Olson a compreende por meio da ideia de um grupo de pressão. Nesse ponto em específico, ao tratar de bens públicos e grandes grupos, o autor expõe a ideia de que a combinação ou conjugação de interesses individuais corresponda a uma feita em um sistema de mercado. Nesse âmbito, Olson trata de organizações que se formam em torno a bens públicos, como no caso do Estado-Nacional.

No entanto, ao tratar da questão da provisão de bens públicos, como no caso da atuação governamental em um determinado tipo de setor econômico, ele deixa claro que, este enquanto tal, acaba sendo alvo da ação desses grupos de pressão. Segundo essa consideração, isso proporciona a existência do fenômeno do lobby.

O lobby é, no pensamento de Olson, a atividade de um grupo específico que age no sentido da garantia dos interesses de seus membros diante de uma organização que constitua assim um bem público, como uma instituição governamental, ou no caso, uma agência reguladora. Em outras palavras, ele age no sentido de produzir um bem coletivo, mas não público.

Cabe lembrar que, ao tratar da questão das cooperativas agrícolas e das organizações de lobistas desses agricultores, Olson recorreu a centenas de entrevistas para as suas considerações enquanto formação de um grupo de pressão específico. Nesse sentido, ele considera que as organizações cooperativas a esse respeito passam pela criação de novas técnicas, ou de técnicas especializadas, para a atuação no setor:

These organizational techniques, which have since been widely copied, have unfortunately never been explained or analyzed in any single publication, and as a result the problems of the farm organizations in general, and the Farm Bureau in particular, have often been misunderstood. (Olson, 2002, p. 153).

Porém, ainda que Olson consiga teorizar a respeito do funcionamento dos grupos de pressão e de interesses em determinadas esferas e ambientes institucionais, ao compreender a ação coletiva e a organização acaba desafiado pela teoria ortodoxa da organização, como no caso do marxismo-leninismo. Aqui, a relação, não de poder de mercado, mas do exercício da coerção, como apresentado por Olson, acaba sendo questionada.

É aqui que Olson, por mais que queira produzir uma teoria que explique as 
organizações de maneira independente de quaisquer situações, acaba tendo que se deparar com a teoria do Estado e da classe na ação social. Nesse ponto, Olson compreende que:

\begin{abstract}
Marxian class action then takes on the character of any endeavor to achieve the collective goals of a large, latent group A class in Marxist terms consists of a large group of individuals who have a common interest arising from the fact that they do or do not own productive property or capital. As in any large, latent group, each individual in the class will find it to his advantage if all of the costs or sacrifices necessary to achieve the common goal are borne by others. "Class legislation" by definition favors the class as a whole rather than particular individuals within the class and thus offers no incentive for individuals to take "class-conscious" action. The worker has the same relation to the mass of the proletariat, and the businessman has the same relation to the mass of the bourgeois, as the taxpayer has to the state, and the competitive firm to the industry(Olson, 2002, pp. 106-107).
\end{abstract}

O ponto é, segundo Olson explica, que grupos que não têm a função de agir economicamente existem, mas os compreende dentro de termos econômicos. Olson centra a sua observação na lógica da própria organização, fazendo com que se atribuam e identifiquem elementos para as suas relações de poder e a sua capacidade de atuação.

Assim, Olson acaba não superando a teoria marxista quanto ao problema da ação violenta, a exemplo do caso do sindicalismo. A capacidade de atuar e coagir seus membros a produzir uma determinada ação, a indivíduos que a princípio não teriam outros recursos, é, de fato, explicada apenas em termos da organização de uma pequena parcela que consegue, por meio da associação no exercício da coação, a geração de um instrumento para exercer esse poder. Aqui ele explica:

Violence is apparently the greatest when unions first try to organize a firm. If the employer's forces win the early tests of strength, the union is apt to disappear and peace will be re-established. If the union wins, the hazards of "scabbing" will likewise be evident and workers will soon make it a habit not to cross picket lines, thereby bringing a period of peaceful collective bargaining. (Olson, 2002, p. 71).

É considerando que a perspectiva de Olson não tem uma preocupação com a ação política - no caso, a partir de diretrizes revolucionárias-, que se retoma aqui a questão do poder, mas diante da própria concepção do neoinstitucionalismo.

Seguindo a linha de pensamento de Geoffrey Hodgson, David Young aponta que a concepção de poder apresentada pelas teorias dominantes de inspiração neoclássica acaba por compreender o poder enquanto um fenômeno centrado no mercado. Junto a isso, a apropriação da teoria dos jogos desenvolvida para os modelos de comportamento estratégico de firmas parte inicialmente de uma ideia de competição na qual o poder é concebido 
enquanto estabelecimento de um monopólio do próprio mercado (Young, 2002, p. 51-52) $\square$.

Nesse sentido, ele compreende que a ideia de poder concebida dentro do padrão da liderança de preço por parte da firma foi acompanhada pela elaboração de diversos modelos que compreendessem o uso e exercício estratégico do poder de mercado, enquadrando-a ao esquema da teoria dos jogos. Contudo, Young considera que, de qualquer maneira, essa concepção de poder segue reducionista por conceber o poder apenas em uma das suas dimensões (Young, 2002, p. 52).

Assim como Olson, Young recorre à crítica marxista da teoria da organização para a discussão sobre outras possíveis dimensões, no sentido de influenciar a atuação econômica dos sujeitos sociais. Em uma contraposição às concepções dominantes que afastam a análise de poder, como a visão austríaca, porém, Young acaba por defender que uma análise mais clara de outras dimensões do poder seja útil para a compreensão da evolução das instituições (Young, 2002).

Com isso, é a partir da ideia de que haja uma perspectiva de poder negligenciada pela Nova Economia Institucional e sua relação com a realidade social dos indivíduos que devemos observar a teoria a partir de seu sentido crítico. Assim, o retorno ao pensamento de John Kenneth Galbraith é frutífero no sentido de compreender a realidade econômica e institucional.

John Kenneth Galbraith, em seu livro Anatomia do Poder, empreende um esforço no sentido de demonstrar os elementos do exercício do poder e das fontes de seu direito. A partir de uma perspectiva que se dá entre a economia e a política, Galbraith expõe os componentes de sua formação enquanto poder.

A princípio, Galbraith toma a concepção weberiana de poder como "a possibilidade de alguém impor a sua vontade sobre o comportamento de outras pessoas" (Galbraith, 1986, p. 2). Argumenta que essa concepção weberiana é corretamente tomada comumente por uma noção que se dá pela relação entre grupos e a imposição de objetivos próprios a outros que não os correspondem.

Contudo, Galbraith coloca que, mesmo que correta, a concepção sociológica weberiana sobre o poder acaba oferecendo a compreensão dele, mas não expressa a sua operação. Por isso, não basta para Galbraith a prerrogativa da função de um poder ou outro, mas sim os instrumentos do exercício do poder e das suas fontes de direito.

Assim, concebe que, para a compreensão do poder enquanto exercício de decisão, se deve compreender a relação dos instrumentos de seu exercício enquanto possibilidade, ou faculdade do sujeito social. Por isso, Galbraith coloca a questão da necessidade da ocultação 
da própria realização do exercício do poder, como se nota nesse fragmento:

\begin{abstract}
Além disso, como veremos adiante em pormenores, boa parte do exercício do poder depende de um condicionamento social que procura ocultá-lo. Aos jovens ensina-se que numa democracia todo poder emana do povo. E que num sistema de livre iniciativa toda autoridade repousa na soberania do consumidor, que opera através do mecanismo impessoal do mercado. Oculta-se, desta maneira, o poder público da organização - do Pentágono, da indústria bélica, de outras empresas e dos grupos de pressão sobre o legislativo (os lobbyists). Dissimulado de maneira similar pela mística do mercado e da soberania do consumidor é o poder das grandes empresas para determinarem ou influenciarem os preços e os custos, subornarem ou subjugarem políticos e manipularem as reações do consumidor. Mas, ao final, tornase visível que as organizações realmente influenciam o governo, dobram-no, e com ele o povo, à sua vontade e aspirações. E também que essas grandes empresas não estão subordinadas ao mercado; pelo contrário, o mercado que supostamente as controlaria torna-se, em parte, um instrumento em suas mãos para fixarem seus preços e receitas. Como tudo isto conflita com o condicionamento social, gera indignação. $\mathrm{O}$ poder, assim dissimulado pelo condicionamento social e então revelado, parece profundamente ilegítimo (Galbraith, 1986, p. 12-13).
\end{abstract}

Revelar ao público essa condição da operação do poder parece ser o objetivo principal de Galbraith com o intuito de revisar o conjunto de sua obra, principalmente após sua experiência trabalhando no governo americano. O que se pode compreender disso é que, em alguma medida, ele entende que é a incompreensão desse aspecto da vida social na gestão econômica, no caso da avaliação imprópria das decisões, que a concepção teórica falha ao analisar, justamente devido aos elementos sociais por ela negligenciados.

É nesse sentido que o autor passa a distinguir três formas de poder, tendo como critério os instrumentos de seu exercício com as fontes de seu direito. São eles: o poder condigno, o poder compensatório, e, por fim, o poder condicionado.

O poder condigno é aquele que se consegue através da capacidade de "se impor às preferências do indivíduo ou do grupo uma alternativa suficientemente desagradável ou dolorosa para levá-lo a abandonar essas suas preferências.” (Galbraith, 1986, p. 4).

Ele esclarece o uso do termo "condigno" a partir da ideia de que este contém em si uma ameaça, ou sanção, de alguma forma uma punição para que seja exercido, mas que de alguma maneira a eficácia de seu exercício depende da aceitação dele pelo assediado, ou seja da submissão deste ao que o exerce.

Já o poder compensatório, segundo Galbraith, é aquele no qual existe uma recompensa à aceitação de seu comando. Nesse sentido, o que se pode observar é que ele em alguma medida implica uma ação posterior da parte daquele que o exerce, a partir do momento do reconhecimento da submissão do assediado pelo poder.

Os recursos - ou ativos- empregados para o exercício do poder compensatório 
podem ser de diversas naturezas, desde uma concessão ou direito, um pagamento pecuniário, em dinheiro, até mesmo um sinal de aprovação ou um simples elogio. De qualquer maneira, há da parte daquele que o exerce uma interação diante do outro (Galbraith, 1986, p. 5).

Os poderes condigno e compensatório são exercidos através de uma aceitação da parte dos assediados, através da crença em um ato posterior, punitivo ou uma sanção como no caso do condigno, ou uma recompensa ou benefício como no caso do compensatório. Sem essa aceitação eles têm seu exercício interrompido, ou inabilitado.

O terceiro tipo é o do poder condicionado. É um poder subjetivo, ou seja, não dispõe de meios de intercâmbio entre as partes para o seu exercício. Depende de um elemento cultural em que, aquele que se submete a esse poder, o faz por estar de acordo com um determinado valor social, de sua comunidade, ou como uma realização apropriada a um determinado grupo.

Nesse sentido, o condicionamento acaba sendo resultado de um estado de valores. Galbraith atenta ao fato de que esse estado de valores pode ser explícito - como no caso de um processo educativo, de instrução escolar ou religiosa- ou por meio de um condicionamento implícito no qual há uma forma de convenção social aceita que implica submeter-se a esse poder (Galbraith, 1986, p. 25-26).

Galbraith compreende que o poder condicionado pode ser exercido através de uma moralidade religiosa ou um doutrinamento específico a um determinado. Trata-se de um poder que se faz por meio de uma persuasão objetiva, mesmo que velada ao outro, como no caso da persuasão publicitária de um determinado produto, ou agenda, a um consumidor.

Entretanto, ele não exclui a sua relevância em questões econômicas e seu papel no interior das relações de poder das empresas enquanto organizações que procuram maximização de lucros. Galbraith considera que:

\footnotetext{
O poder condicionado também é de grande significação na vida econômica. O trabalhador médio só reage ao poder compensatório; na ausência deste não trabalharia. Entretanto, em quase todas as tarefas, exceto as mais entediantes e estafantes, o trabalhador se orgulha do seu trabalho e reflete em sua realização aquilo que Thorstein Veblen chamou de instinto para a arte no trabalho. Este instinto torna-se cada vez mais importante e reconhecido à medida que o indivíduo ascende na hierarquia da grande empresa. O diretor-presidente (ou o aspirante ao cargo) orgulha-se de realmente acreditar naquilo que está fazendo. A remuneração do executivo ainda é uma grande motivação; mas os propósitos da empresa estão profundamente incorporados à sua crença e têm uma força independente. Crê que tais objetivos são bons e corretos, e essa crença é uma manifestação altamente eficaz do poder condicionado. (Galbraith, 1986, p. 29).
} 
ou por outra dessas três formas. O que há é uma realização do exercício desse poder que pode sim ter mais instrumentos no mesmo ato. E é a partir desse momento que devemos compreender os elementos que dão base para o exercício do poder em suas três formas.

Ao considerar os instrumentos do poder, Galbraith concebe três tipos: a personalidade, a propriedade e a organização. É a partir desses três tipos de poder que ele concebe os elementos que capacitam os que aspiram a exercer o poder a fazê-lo. A personalidade é um instrumento fundamental nesse exercício. Enquanto tal, ela se associa ao poder condicionado:

\begin{abstract}
Cada uma das três fontes de poder tem uma relação estreita, embora nunca exclusiva, com um instrumento específico de imposição. A organização está associada ao poder condicionado; a propriedade, desnecessário dizer, ao poder compensatório. A personalidade tem uma associação original e duradoura com o poder condigno; antigamente se conseguia a submissão pela superioridade física, ou seja, pela capacidade de infligir castigo físico aos recalcitrantes ou não conformistas. Esta associação tradicional ainda encontra certa ressonância no mundo moderno. Permanece particularmente importante entre as crianças; há uma deferência natural diante do rapaz (ou, ocasionalmente moça) fisicamente mais forte do grupo. Aquele que recorre com demasiada frequência ou ostentação a esta fonte de ação condigna é conhecido e recriminado como um fanfarrão. Costuma-se supor que, quando as crianças amadurecem e se tornam presumivelmente mais civilizadas, recorrerão cada vez menos a esse poder condigno e diminuirá de importância sua fonte na personalidade. (Galbraith, 1986, p. 40).
\end{abstract}

Nesse sentido, o que se pode considerar é que a personalidade, enquanto instrumento de poder, é aquela que dinamiza a ação dos demais sujeitos sociais. Com isso, o autor acaba por considerar que a personalidade enquanto fonte de poder se faz exercendo-o e não pelos atributos pessoais do indivíduo enquanto tal:

\begin{abstract}
Na comunidade moderna, a associação mais importante da personalidade é hoje esta conexão com o poder condicionado. A personalidade autêntica submete persuadindo - cultivando a crença, 'exercendo liderança'. Uma certeza suprema nas próprias convicções e asserções de importância capital para conquista a crença e a submissão de outros, e este atributo pessoal não está necessariamente ligado à inteligência. Pode inclusive ser o seu reverso. Uma das características básicas da política econômica, exterior e militar, assim como de muitas políticas comerciais, é que a conexão entre uma determinada medida e o seu resultado é incerta, na melhor das hipóteses, e muito frequentemente desconhecida. Ninguém pode dizer com certeza qual será a consequência final de um determinado aumento nas taxas de juros, de uma proposta de apoio político a um governo relapso, de uma iniciativa militar ou bélica cuidadosamente planejada; nem qual será o retorno de um empreendimento comercial. Nesses casos, o poder - a submissão à vontade - passa normalmente para aqueles capazes de asseverar o desconhecido com a máxima convicção. O poder advém não para um indivíduo que sabe e, sim, para aquele que, muitas vezes por obtusidade, acreditar saber e que consegue persuadir outros a essa crença. (Galbraith, 1986, p. 4-5).
\end{abstract}

Portanto, da mesma maneira que os teóricos aqui tratados, Galbraith confere à organização um papel fundamental na mudança social. $\mathrm{O}$ autor a toma como sendo a fonte transcendental de poder. Em outras palavras, ela é a única fonte do poder capaz de 
transformar todo o quadro social, enfrentar outras fontes de poder, e em alguma medida, empreender uma mudança social profunda.

Sendo assim, ao compreendermos o pensamento de Galbraith diante de sua obra teórica e sua ação pública, podemos retomar aquilo que se discute enquanto teoria em Economia Institucional. Em seu esforço, Galbraith em alguma medida revela o exercício do poder e da imposição das circunstâncias diante das naturezas, mediando relações econômicas com as sociais. Porém, sua preocupação principal é como o poder é exercido, não apenas enquanto uma vontade, ou um projeto, mas como resultado objetivo de uma interação real entre sujeitos sociais dotados de ativos distintos na realização social.

Com isso, é necessário retomar a Galbraith por conta da concepção realista política que este apresenta enquanto uma análise em teoria social. A organização, enquanto elemento fundamental da mudança institucional deve ser vista também em sua capacidade de agregar indivíduos.

A esse respeito, a obra Saída, Voz e Lealdade de Albert O. Hirschman (1973) é de extrema utilidade para a compreensão desse fenômeno, em sua análise da questão da adesão a firmas e organizações de diferentes naturezas.

Diante do problema de uma ineficiência na qual não se observa uma relação clara e de uma queda de desempenho das organizações, Hirschman aponta para a ideia do slack. Esse fenômeno se dá nem por diminuição do esforço devido à satisfação já alcançada, assim como pela insatisfação generalizada de indivíduos egoisticamente motivados (Hirschman, 1973).

A economia de slack se dá nas unidades comportamentais, ou seja, nos agrupamentos que dizem respeito ao declínio ou decomposição da organização enquanto tal, que em alguma medida são lapsos de comportamento racional. Aqui Hirschman trata de afastar a análise de elementos macroeconômicos, ou de categorias econômicas universais, já que os economistas que as propuseram não tinham o propósito de analisá-los por conta da concepção de racionalidade imutável de seus modelos.

O problema posto é que, uma vez que os indivíduos componentes dessas organizações se deparam com um ambiente em mau funcionamento, conforme Hirschman aponta, eles têm a possibilidade de três escolhas: a saída, a voz e a lealdade.

Segundo Hirschman, a saída é quando, diante da relação conflituosa, o indivíduo deixa a organização. Nesse ponto, o autor aponta que há condicionantes para esse tipo de comportamento, uma vez que a existência de organizações rivais induz o indivíduo a procurálas na medida em que a saída da primeira organização tenha seu custo diminuído.

Já a voz é considerada uma alternativa à saída. Hirschman aponta que, diante do 
problema da relação entre o indivíduo e a organização, já que o primeiro procura meios de manter-se na organização a fim de propor demandas e alterar arranjos, mudando então a relação do que resulta da atividade da organização para ele.

Por fim, Hirschman acaba por propor uma teoria da lealdade, na qual a relação entre os agentes tem, entre a voz e a saída, uma concepção de poder correspondente à da estrutura de mercado existente no seu meio. Em outras palavras, a substituição de uma adesão à outra, ou a própria consideração de que não haja alternativa a ser buscada, acaba imprimindo um determinado tipo de adesão ao grupo no sentido de considerar a sua manutenção dentro dele.

A esse respeito, Hirschman considera que a estrutura de mercado das organizações influencia a escolha entre uma, ou outra, das decisões. Porém, a existência de uma concorrência não necessariamente implica uma alternativa para a saída da organização, pois ela pode, na verdade, prover essa organização de uma relação monopolista, dada a inadmissibilidade da decisão (Hirschman, 1973).

Portanto, experiências comuns para a difícil aceitação no grupo, ou a ideia da sua funcionalidade, acabam conformar a escolha entre sua saída ou manutenção no grupo. Contudo, a voz, passa a ser então uma função da lealdade, no sentido propositivo de sua própria consideração por parte do indivíduo.

Dessa maneira, pode-se considerar que a relação entre os indivíduos nessa relação é de duas naturezas. Enquanto caracterização dessas decisões, pode se dizer que, para Hirschman, a saída é uma operação econômica, enquanto a voz se constitui como uma operação política.

Em suma, a concepção de Hirschman parte da ideia de que primeiro o indivíduo na organização ativa a voz, encontrada a solução, fica contida a questão. Em caso da sua negativa, haverá a busca pela opção da saída.

Por outro lado, a compreensão de Hirschman só residindo na contradição dos interesses, ou no mal-estar do indivíduo ao pertencimento organizacional, é redutora da compreensão do meio social, que acaba limitado, ou pouco explicativo, quanto à compreensão do fenômeno da cooperação.

Elinor Ostrom (2007) defende que, ao se observar as mudanças institucionais, deve-se atentar para dados empíricos, de campo, que corroborem uma determinada interpretação. Em vez de propor apenas uma teoria, como também o fez, Ostrom propõe um método para a análise da mudança institucional.

A autora focaliza a análise na situação da ação, que compreende sete elementos de interação: 1) os participantes, 2) suas posições, 3) as ações, 4) o controle da escolha em um determinado ponto, 5) a informação detida, 6) os resultados possíveis, e 7) os custos e 
benefícios (Ostrom, 2007).

Para a autora, não é a ideia de direta das regras, normas e estratégias que importa na análise da mudança institucional, mas sim a sua representação. Portanto, a representação de regras, formais e informais, não seria por si suficiente para a análise, mas sim a compreensão das regras em uso numa determinada situação, que só poderia ser averiguada numa pesquisa a campo, inclusive prevendo analiticamente a concepção de um default, ou uma situação em que haja a ausência de regras.

A crítica de Hegenberg à elaboração de lógicas situacionais, como citado acima, é encarada através dessa relação clara que se faz entre a teoria e a empiria no método apresentado por Ostrom. Ela propõe, em vez da produção de conhecimento por parte de teorias que observavam a realidade de forma estática, a adaptação dos conceitos utilizados no sentido de sua evolução, o que implica diferenças no da mudança evolucionária.

Com isso, a autora propõe um modelo de indivíduos que tenham racionalidade limitada, o uso de uma norma potencial e o acesso à informação nessa situação determinada. Nesse caso, então, ela passa a construir fundamentalmente o seu pensamento a respeito do fenômeno da cooperação.

Ostrom desafia os modelos de racionalidade baseados no individualismo metodológico e compreende que o fenômeno da cooperação não resulta apenas de um ponto ótimo de escolha, a exemplo do caso paretiano. Entende que há duas questões a serem observadas ao tratar de casos em que os indivíduos conseguem resultados superiores aos conseguidos se feitos de modo autointeressado e que são fatores sociais que tem influência nesse tipo de resultado.

A autora considera ainda que esses fatores sociais são: reciprocidade, reputação e confiança. Quanto especificamente à reciprocidade, Ostrom explica que a atribuição à racionalidade, por ter um comportamento egoísta, por conta de um dilema social em uma situação de incerteza, não procede por pesquisas empíricas. De fato, o que há mesmo diante da incerteza, é a compreensão de que a cooperação pode gerar a sua contraparte, de acordo com o prolongamento da interação entre os agentes:

To generate predictions other than noncooperation, theorists using standard rational choice theory have found it necessary to assume real uncertainty about the duration of a situation or to assume that some players are "irrational" in their willingness to reciprocate cooperation with cooperation. To assume that if some players irrationally choose reciprocity, then others can rationally choose reciprocity is a convoluted explanation - to say the least - of the growing evidence that reciprocity is a core norm used by many individuals in social dilemma situations. (Ostrom, 1998, p.4). 
É a partir da expectativa, portanto, de um possível resultado dado um determinado tipo de ação que, para Ostrom, a cooperação é também uma norma estratégica. Em outros termos, a cooperação é uma estratégia inerente à ação humana, pois enquanto um princípio ela corresponda à reciprocidade.

Contudo, cabe lembrar, a reciprocidade para Ostrom não é um elemento salvador, humanístico e altruísta, por excelência. Na verdade, ela é uma estrutura de interação que, se somada à reputação e à confiança, construídas na duração da interação, propicia interações cooperativas. Do contrário, a reciprocidade também compreende a ideia de que se leve a um desenvolvimento interativo hostil entre os agentes (Ostrom, 1998).

\subsection{DAS TROCAS E SUAS CONSEQUÊNCIAS}

Partindo da concepção de Ostrom de reciprocidade e de governança dos recursos de uso comum, Eric Sabourin (2010) demonstra esse tipo de relação social no Brasil. No seu caso, Sabourin trata especificamente da estrutura social formada em torno à troca social e à reciprocidade.

Posteriormente, o próprio autor expõe de forma direta a relação entre as ideias de estrutura de reciprocidade e de troca social. Dessa maneira, ao expor a reciprocidade na condição de uma troca, Sabourin retoma a concepção de Chabal (1998), colocando que:

A palavra reciprocidade significa a existência de uma relação de um primeiro termo
para um segundo, bem como do segundo para o primeiro. A reciprocidade é uma
relação que se redobra. A etnologia adotou esta palavra para designar as prestações
econômicas e simbólicas das sociedades tradicionais. Mas estas prestações são
muitas vezes confundidas com formas primitivas da palavra troca. Quer se entenda
troca no sentido restrito de troca mercantil, quer se entenda no sentido geral de
circulação de bens, trata-se, de qualquer forma, de uma transação que diz respeito a
objetos. Ora, as prestações de reciprocidade descobertas pela etnologia colocam em
evidência uma relação entre as pessoas. A operação de troca é uma permutação de
objetos, a estrutura de reciprocidade constitui uma relação reversível entre sujeitos.
(Sabourin, 2009, p. 64).

Recorrendo a Karl Polanyi, Sabourin expõe que ele considera então que a troca enquanto elemento da ação humana e do comércio humano. Dessa maneira, Polanyi distingue a permuta, como troca operacional, e a troca, a preço pré-fixado, como troca decisiva, sendo estas duas primeiras trocas as que visam repartição de um terceiro tipo de troca, a troca 
integrativa. Nesta, o preço que envolve a troca é feito a partir de uma negociação, que visa a maximização do lucro (Sabourin, 2011).

Sabourin atrela a questão da reciprocidade através do pensamento de Marcel Mauss e de Claude Lévi-Strauss a respeito do grau máximo de sua condição, que é dado pelas relações de parentesco. É através da linhagem, em outros termos, de sangue, que a reciprocidade, bem como sua reversibilidade, se expressa mais claramente. É através dessa proposição teórica que ele considera que são estabelecidas as estruturas da, já referida, reciprocidade, que acaba se configurando de acordo com os atores sociais nela envolvidos.

Em suma, a estrutura de reciprocidade, segundo Sabourin, pode ser classificada segundo as seguintes propriedades: binária, ternária ou em rede; simétrica ou assimétrica; unilateral ou bilateral.

Figura 10 - Estrutura de reciprocidade

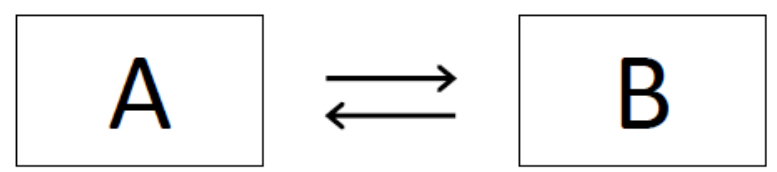

Fonte: Sabourin, 2009, p. 58

Para Sabourin, a troca mercantil é o extremo oposto da reciprocidade. Nesse sentido, entende que a ajuda mútua, ou mutirão, e o manejo de bens comuns são as duas instituições fundamentais da reciprocidade, sendo o arranjo do grupo em torno delas o que faz com que se crie outra determinada configuração de sua dinâmica.

Sendo assim, é aqui que, apesar da teoria williamsoniana das estruturas de governança explicar a formação de arranjos que relacionam a intermediação entre o indivíduo e o ambiente institucional, entende-se que essas estruturas enquanto tais não podem ser compreendidas sem uma concepção da realidade social. É partindo dessa consideração que se trata aqui da ideia dela enquanto uma estrutura.

Sabourin considera que a reciprocidade um valor moral, dada a espiritualidade da relação entre dádiva e contradádiva na relação entre os agentes, que acaba se refletindo nos condicionantes da cooperação em Ostrom, que não podem também buscar nada além de sua própria reprodução. Nesse ponto, ele tem por princípio uma diferença com Ostrom, no sentido de compreender que a autora desvirtua, por conta da natureza epistemológica da sua 
produção, a teoria da reciprocidade:

\begin{abstract}
Apesar das evidências empíricas e de uma intuição recorrente em torno da relação íntima entre reciprocidade, confiança e reputação, Ostrom permanece dentro dos limites do postulado binário da troca e das expectativas da sua regulação por uma minoria de indivíduos altruístas e "reciprocitários", interagindo via redes. Para explicar a reciprocidade, ela recorre previamente à confiança, enquanto que, para a teoria da reciprocidade, são as relações de reciprocidade simétrica nas estruturas de compartilhamento (de recursos comuns) que produzem a confiança. Aliás, é o que mostram as repetições modeladas de jogos que fazem intervir a confiança e a reciprocidade, quando introduzem uma variável de conhecimento do comportamento do outro a partir da experiência. (Kahan, 2005 citado por Sabourin, 2010, p. 155).
\end{abstract}

Entretanto, ainda que Sabourin compreenda a diferença entre as concepções de reciprocidade dele e de Ostrom, nota-se um problema da sua interpretação. Ainda que Ostrom se limite de fato a essa suposição teórica, a diferença observada por Sabourin está fora do propósito do conhecimento científico.

Posteriormente, ao tratar da questão da relação de confiança com a reciprocidade, ele recua a esse respeito e entende quando Sabourin diz:

\begin{abstract}
A teoria da reciprocidade não nega a existência do princípio de troca, do ponto de vista econômico ou social, ao contrário. Tampouco está propondo uma substituição sistemática das relações de troca por relações de reciprocidade. Apenas chama para uma dupla leitura, pois cada uma dessas lógicas - troca e reciprocidade - podendo ser averiguada nos fatos, pode prevalecer-se de vantagens respectivas e, principalmente, de conquistas, dentre as quais, algumas são, sem dúvida, irreversíveis. A proposta não consiste em negá-las ou, ainda menos, em pretender voltar às origens (Sabourin, 2011, p. 43-44).
\end{abstract}

Finalmente, ele compreende a relação entre sistemas mistos e a interface entre espaço da troca e da reciprocidade. Aqui ele passa a entender que:

\begin{abstract}
Nesse sentido, surgem várias dificuldades de articulação que remetem às dinâmicas próprias de cada uma das formas de economia colocada em situação de hibridação, que constitui apenas uma das formas de articulação entre lógica de troca e lógica de reciprocidade. Trata-se da forma positiva onde opera uma complementaridade entre relações de troca e relações de reciprocidade, como, por exemplo, no caso dos mercados de proximidade (Sabourin, 2006a e b; Sabourin \& Tyuienon, 2007). Em outras situações pode prevalecer a tensão ou contradição entre as duas lógicas, o que leva a paralisar um dos dois sistemas (Temple, 2003). Pode ainda existir situações de coexistência separada, como, por exemplo, a coabitação de mercados de troca e de mercados de reciprocidade nas mesmas feiras em cidades dos países andinos. (Yampara, Mammana \& Calancha, 2007; Yampara \& Temple, 2008), citados por Sabourin, 2013, p. 25.
\end{abstract}

Assim, em sua tentativa de marcar uma diferença com Ostrom, acaba também por reconhecer uma parte de sua contribuição ao oferecer uma via no sentido de compreender a 
sociedade diante do mercado. O intercâmbio material autointeressado deve reconhecer necessariamente, em algum grau, o mínimo de reciprocidade, nos termos de Sabourin, já que se descarta na situação de intercâmbio, dentre outras coisas, o uso da violência.

De qualquer forma, o problema do valor moral que se constrói em torno à reciprocidade se abre como um problema na teoria. A ideia da reputação como exposta nos termos de Ostrom é um exemplo disso.

Com isso, faz-se necessário aqui a apropriação da concepção de Geoffrey M Hodgson e as comunidades morais. $\mathrm{O}$ autor tece uma série de considerações a respeito da caracterização social da economia institucional e do desarranjo do seu desenvolvimento epistemológico ao tomar para si um conjunto de pressupostos analiticamente impossíveis. Um desses pressupostos é o do individualismo metodológico. Ao tratar do modelo do Homo oeconomicus, Hodgson principia:

Economic man has dominated economic discourse for more than a century. He is rational and self-interested. On his utility-maximizing persona, economists have erected many theories of economic behavior. His well-ordered preference function is used to explain human cooperation and organizational cohesion, as well as his preoccupation with acquisition and pecuniary incentives. But numerous experiments seem to have shaken key theoretical predictions. The purely self-interested individual has proved elusive. With his one-dimensional objective of utility, economic man has been given too heavy a burden to bear. He has expired under its weight. May he rest in peace. (Hodgson, 2013, ix).

Hodgson considera que a moral, enquanto um fenômeno, é um dado inserido a um determinado grupo. Não é possível concebê-la atomizada a um determinado indivíduo, sem que este esteja ligado a alguma coletividade, porque a própria concepção da moralidade é dada em sua interação.

Disso decorre uma diferença clara entre os pressupostos dos modelos de homem dados nas teorias econômicas ao tratar do elemento de um grupo específico como a família em seu laço máximo de parentesco. Com isso, a ideia da reciprocidade dentro desse âmbito é expressa por ele:

The family is at variance with the twin utopias of socialism and pro-market individualism. Individualists who regard the market as the solution to problems of organization and allocation give inadequate explanation of why they refrain from the commercialization of all family relations. If, by contrast, they cherish "family values" and the solidity of that institution, then they have to recognize the practical and moral limits of market imperatives and pecuniary exchange. (Hodgson, p.232).

Portanto, a orientação dada pela perspectiva da Economia das Organizações e da Economia Institucional deve tomar a transação como unidade de análise. Estando dentro do 
universo das formas de interação social a troca, e sendo ela também elementar para a realização da transação, passa-se então a identificar a transação.

Nesse sentido surge a ideia de que onde há um problema de agência reduz-se o ambiente social que proporcionaria a manutenção das instituições dessa organização social. Isso nos leva diretamente ao problema da interação em vias de poder por parte dos agentes sociais por conta da sua relação.

A partir da ideia de Galbraith de que o poder é exercido e que é necessário compreender as formas de seu exercício e as fontes de sua existência acabamos retomando um ponto crucial da análise institucional: a ideia de que haja uma separação entre organizações e instituições, ou mesmo a atribuição entre um tipo determinado de organização que seria uma instituição, ou o contrário, leva a uma confusão analítica e a um impasse teórico.

Isso se dá pelo fato de que a resolução desse impasse apenas por meio de um exercício racional intelectual, desprovido de um elemento de observação ou convívio social real, se dá pela tomada de conhecimentos humanos de outra natureza - muitos não científicos, como debates axiológicos, filosóficos, semióticos, etc.-, que são somados à elaboração teórica inicial. Porém, essa evolução, por ter um ímpeto analítico, decompondo os elementos e tratando de identificar as suas relações, se torna complexa a ponto de ter um sentido epistêmico que é capaz de incorporar infinitos fatores, formando categorias cada vez mais particulares e específicas que, ao fim, não auxiliam a compreensão da realidade social.

Nesse caso, o que compreendemos é que a divisão constatada por North existe, assim como exposta por Hodgson. Porém, o que se afirma aqui é que, tomado o pensamento de Galbraith, não é possível pensar organizações e instituições tanto separadamente, como atribuindo a uma ser a outra, ou no caso de Hodgson, que a organização seria um tipo especial de instituição.

Elas são, de fato, categorias distintas da análise. Porém, não é possível existir uma instituição que influa na ação de outros agentes, sem uma organização correspondente que a exerça, assim como não é possível que exista uma organização sem uma instituição que coordene a primeira enquanto um grupo correspondente que a represente.

A identificação da categoria correspondente de uma a outra se dá pelo nível de seu exercício ou representação. Em outras palavras, reconhecida a instituição, de uma maneira ampla, é possível encontrar a sua correspondente organizacional, mas não necessariamente, agir em seu exercício, defendendo a manutenção de suas regras e normas. Ao se constatar uma organização, é possível encontrar uma instituição que aponte à ação desse grupo ou coletividade, mesmo que inconscientemente, por parte de quem age por esta instituição. 
Assim, a eficácia do seu exercício ou a viabilidade de sua representação depende, portanto, da relação entre a organização que exerça o poder que resulta na instituição que a representa e, logo, não é possível pensar a mudança institucional sem a reflexão do poder. Assim, o debate da operação do poder e das trocas sociais na interação entre os seus agentes implica a compreensão da transação enquanto unidade de análise e nas relações de poder enquanto barganha.

\subsection{TEORIA DA TROCA SOCIAL - BARGANHA}

Desta forma, passa a ser importante compreender a relação que existe entre poder e troca. Assim, devemos passar ampliar a reflexão acerca da discussão sobre a cooperação. $\mathrm{Na}$ interação social, observa-se de fato uma relação de troca. Por isso, cabe observar as contribuições em Teoria Social a respeito da Teoria das Trocas Sociais.

Segundo a orientação dada pela perspectiva da Economia das Organizações e da Economia Institucional, deve-se tomar a transação como unidade de análise. Sendo, dentro do universo das formas de interação social, a troca, e sendo ela também elementar para a realização da transação, passa-se então a identificar a transação.

Nesse sentido, deve-se considerar que há um determinado domínio da interação social que tem, por sua vez, suas categorias operacionais, que abordaremos aqui. A teoria das firmas considera que a unidade de análise fundamental da economia das organizações é a transação. Nesse sentido, cabe a compreensão da transação.

A transação é a realização da interação em termos econômicos de uma ação coordenada entre indivíduos. Pode supor uma troca, porém não se restringe a ela.

Oliver Williamson considera que as transações possuem as características de frequência, incerteza e especificidade dos ativos, tendo como correspondência de sua realização a caracterização dos agentes envolvidos. Nesse ponto, considera oportunismo, elementos de racionalidade limitada, reputação, garantias legais e princípios éticos como componentes dessa relação.

Hodgson, porém, apresenta a limitação de uma falsa dicotomia apresentada por Williamson, no sentido de demonstrar que há relações de mercado, relações hierárquicas e formas híbridas ou contratuais. O ponto é que, ao observar a relação de transação e barganha por esse viés teórico, alega Hodgson que não se prevê a questão de uma troca contratual não mercantil, o que é absolutamente plausível enquanto possibilidade. 
O estudo da barganha em economia tampouco é recente e teve avanços, sobretudo na área de teoria dos jogos. Diversos avanços nesses estudos têm sido observados com a agregação de mais variáveis de análise, além de uma sofisticação dos instrumentos de análise de dados quantitativos que apoiam explicações teóricas a partir da elaboração de modelos condizentes com a fundamentação do individualismo metodológico.

Tomemos a esse exemplo a obra Bargaining and Markets, de Martin Osborne e Ariel Rubinstein (2005), abordando esse problema. Ofereceram um instrumento teórico de articulação e previsão de ações a partir de um modelo teórico com base na formulação de dois modelos teóricos tendo como base do problema da barganha: um é o modelo axiomático tomando a solução de Nash, já o outro é o modelo estratégico de ofertas alternadas.

Para os fins de nossa discussão nesta pesquisa, podem-se apreender desses autores três pontos elementares. O primeiro quanto ao caráter epistemológico das teorias desenvolvidas; o segundo relativo aos modelos de comércio existentes nessas teorias; e, por fim, sobre a caracterização da barganha dentro da interação existente entre os sujeitos envolvidos.

Ao tratar do caráter epistemológico das teorias existentes, Osborne e Rubinstein consideram duas formas de teoria: uma de caráter axiomático e outra de caráter estratégico. $\mathrm{O}$ suposto teórico é de que, independentemente do resultado das ações entre os agentes, o conflito direto entre os agentes está fora de questão.

Já em relação aos modelos de comércio desenvolvidos, os autores afirmam que há dois tipos possíveis. Um é a barganha estritamente bilateral, em que a transação se realiza na contradição de interesses de dois sujeitos sociais. Já o outro é a formação de um tipo de comércio em rede, onde a relação de interação depende de ações de partes influentes, mas não diretamente envolvidas e que há um tipo decentralizado de comércio onde se supõe a existência de um equilíbrio competitivo como solução da situação da barganha inserida dentro do mercado como um conjunto.

Finalmente, o terceiro ponto, e o mais relevante para o trabalho em questão, é o que se dá a partir da caracterização da barganha diante da interação dos sujeitos. Osborne e Rubinstein consideram que o resultado das interações em barganha pelos agentes envolve variáveis exógenas à relação entre os jogadores (Osborne \&Rubinstein, 2005) $\square$.

Assim, o sentido da interação da barganha pode se dar em termos nos quais pode haver um incentivo exógeno para a tomada das decisões se a realização do seu resultado, ou pode haver empecilhos ao jogo no qual esses jogadores estão inseridos, onde ao menos uma das partes envolvidas acaba recusando a ação, impedindo a resolução desse jogo.

Dessa maneira, é a caracterização da barganha o ponto que aponta para a propensão 
das interações. É a disposição dessas variáveis que acaba por corresponder se a barganha condiciona uma competição ou uma cooperação entre os agentes.

Contudo, uma característica geral desses estudos em teoria dos jogos é a de constituir um modelo de homem enquanto sujeito social com pressupostos claros, assim como considerações sobre a sua racionalidade. Assim, não se trata aqui de criticar os desenvolvimentos desses estudos dentro dos seus próprios parâmetros, mas sim diante das interações sociais em que a imersão do sujeito individual tem contingências claras influenciando o resultado da sua ação.

Em seu trabalho O Problema do Custo Social, Ronald Coase trata especificamente da disposição da barganha em atividades agrícolas em relação à concessão e troca de uso. A ideia da viabilidade pela redução do custo social, através da perspectiva da unidade de análise da transação é tomada por ele da seguinte forma:

O agricultor estaria disposto a firmar um acordo no sentido de deixar a terra não cultivada por qualquer pagamento acima de \$2. Há, claramente, espaço para uma barganha mutuamente satisfatória, o que levaria ao abandono do cultivo da terra. Contudo, o mesmo argumento serve não apenas ao total de terra cultivada pelo agricultor, mas, também, a qualquer subdivisão da mesma. Suponha, por exemplo, que o gado tenha uma rota bem definida, vale dizer, em direção a um riacho ou a uma área de sombra. Nessas circunstâncias, o dano causado à safra, ao longo da rota definida, pode ser grande e, em assim sendo, o agricultor e o pecuarista poderiam achar lucrativo fazer uma barganha que tenha como resultado a concordância do agricultor em não cultivar a referida faixa de terra (Coase, 1960, p. 5).

Nesse sentido, Coase consegue expor que, a partir da determinação do sistema de preços, a barganha e o uso da troca se dão nessa relação. Isso dado, Coase segue:

\footnotetext{
O objetivo do agricultor seria o de induzir o pecuarista a lhe pagar em troca do nãocultivo da terra. $\mathrm{O}$ agricultor não conseguiria receber um valor superior ao custo de cercar esse pedaço de terra, nem um valor tão alto a ponto de levar o criador de gado a abandonar o uso da terra vizinha. O montante a ser pago, na prática, dependeria da perspicácia do agricultor e do pecuarista como negociadores em uma barganha. Mas, já que o pagamento não seria tão elevado a ponto de levar o pecuarista a abandonar a localidade vizinha, e como não variaria com o tamanho do rebanho, tal acordo não afetaria a alocação de recursos, mas, simplesmente, alteraria a distribuição de renda e riqueza entre o criador de gado e o agricultor. (Coase, 1960, p. 5).
}

Assim, Coase demonstra que, a partir das categorias dispostas em sua teoria sobre o custo social e a disposição de ativos num determinado espaço e a distribuição de elementos intercambiáveis configuram então um tipo de negociação ótima na qual os recursos teriam um aproveitamento superior, evitando custos sociais, assim como transacionais. É por essa 
concepção de que se configura uma situação de barganha que induz as partes a transacionar, tomando as vias daquilo que lhes traria um menor custo transacional, que se compreende a barganha em um sentido mutuamente satisfatório, ou se faz necessária alusão à noção de "barganha cooperativa", como será apresentado adiante. 


\section{CHAYANOV E EMELIANOFF ENTRE A COOPERAÇÃO E A REVOLUÇÃO}

Como visto na discussão anterior, sobre as diferentes teorias em economia institucional e as críticas feitas a elas, uma grande parte dos problemas que enfrentam refere-se à da proposição teórica diante da realidade social imposta. Ainda que do ponto de vista de uma abstração as teorias avancem, elas acabam renunciando cada vez mais ao seu escopo explicativo.

Ao se tratar de estruturas de governança em cooperativas agrícolas usando as teorias apresentadas no capítulo anterior, coloca-se o mesmo problema, ou se propõe uma teoria institucional que, em sua abstração própria obscurece a visão sobre a sociedade, ou teorias críticas que acabam não correspondendo aos problemas da governança. Assim, procura-se aqui superar esse impasse.

O objetivo deste capítulo do trabalho é apresentar de forma breve dois autores contemporâneos da Revolução Russa - evento que marca o triunfo do marxismoleninismo- que trataram dos desafios das cooperativas em seu país e alguns elementos de suas teorias, assim como parte de teóricos que partem das concepções iniciadas pelos dois. Os trabalhos de Alexander Vassilievich Chayanov e Ivan Vasily Emelianoff são pedras fundamentais de duas tradições distintas de pensar o problema da cooperação agrícola.

O primeiro influenciou, sobretudo, os estudos sobre o campesinato e sociedades camponesas, em um enfrentamento claro à ortodoxia marxista após a morte de Lenin, pensando a cooperação a partir da economia peculiar dos camponeses. O segundo foi um teórico no sentido estrito, extraindo do conhecimento então presente, elementos econômicos para a reflexão teórica autônoma, ou pura, sobre a cooperação.

A Revolução Russa de 1917 foi um marco histórico da ordem social não somente na Rússia, mas em todo o mundo, estendendo-se durante o período dos governos transitório, entre fevereiro a outubro de 1917, e bolchevique após a Revolução de outubro. A partir de então a Rússia, agora União Soviética, passa por uma experiência de reorganização econômica, com a implantação do comunismo de guerra que se faz em meio a guerra civil. Este se baseava na expropriação e na nacionalização 
das propriedades, que passavam a ser controladas por uma ampla burocracia. A proposição de substituição da direção técnica das indústrias, fazendas e outras organizações econômicas passa a ser feita através da supressão da propriedade privada desses meios, passando então ao controle de organizações de trabalhadores.

Ao tomar controle dessas organizações, os trabalhadores passaram a defender as cooperativas como forma de gerir sua produção. Ainda que tenha se tornado uma política de Estado pelo governo soviético, a abertura econômica logo após a guerra civil russa entre 1917 e 1921 acabou se dando em grande parte por conta de uma delegação das atividades às iniciativas individuais. Inaugurou-se o período da Nova Política Econômica (NEP) entre 1921 e 1928.

Contudo, antes mesmo de a própria revolução acontecer a Rússia já experimentava um crescimento do cooperativismo e de suas organizações. Porém, esse crescimento se dava em meio uma abertura econômica à livre iniciativa ainda no governo do Czar.

\subsection{ALEXANDER VASSILIEVICH CHAYANOV (1888-1937)}

Alexander Vassilievich Chayanov (1888-1937) foi um agrônomo russo que fez diversos trabalhos em economia agrícola. Sua obra mais lembrada é a da elaboração de uma teoria do campesinato. Para ele, o campesinato, enquanto uma forma de produção distinta da dominante, seria, de alguma medida, movido por uma dinâmica distinta da dominante no sistema capitalista, e assim ele a via como sendo capaz de se reproduzir diante das transformações técnicas da atividade agrícola e da ocupação dos campos.

Num momento histórico em que a interpretação leninista do desenvolvimento do capitalismo na Rússia foi publicada em 1899, e que era dominante após o triunfo revolucionário, e que no caso, se buscava uma autêntica interpretação marxista para as explicações científicas, Chayanov se colocava numa posição desconfortável. Com isso, a recepção em torno as suas teses passou a ser problemática, até por ser perfazer argumentos e concepções se não comuns ou semelhantes, ou pelo menos próximos, aos de Karl Kautsky ${ }^{3}$, à medida que se estabilizava um grupo concorrente em meio às

\footnotetext{
${ }^{3}$ Karl Kautsky, (1854-1938) líder da Social Democracia Alemã, estudioso marxista e autor da obra $A$
} 
disputas políticas na URSS.

Ao se tentar atribuir a Chayanov uma filiação política, considera-se que ele poderia ser considerado um narodnik ${ }^{4}$ —ou, pelo menos, acabou sendo considerado um durante o acirramento da disputa entre narodniks e marxistas. Porém, seu pensamento autêntico e teoricamente vivaz acabou por colocar diferenças insuperáveis para esse tipo de atribuição, já que se opunha ao método de violência política pela via do terror para as suas finalidades, posição adotada pelos narodniks. Ao ter que depor na Lubyanka, uma famosa prisão russa, ao chefe do departamento secreto da polícia GDPU, em 1921, quando ele "confessa" ser um "neonarodnik", algo selaria seu destino com a ascensão de Stalin ao poder. Franz Bourgholtzer (1999) revela sua confissão em meio aos documentos dos arquivos:

\begin{abstract}
My invitation to join the staff of the Narkomzem R.S.F.S.R. in 1921 in the very first weeks of the NEP was brought about by Kuraev precisely because at that time I found myself in the full flower of enthusiasm for NeoNarodism. This wording satisfied Agranov's requirement that Chayanov 'confess' to NeoNarodism. The same wording fulfilled Chayanov's own agenda, establishing for the record that the Bolsheviks had invited him to join their government precisely because he was a Neonarodnik. He went on to spell out his definition of his NeoCadet: 'a theory for the development of agriculture on the basis of cooperative peasant households, a peasantry organized cooperatively as an independent class and technically superior to all forms of agricultural organization (Bourgholtzer, 1999, p. 15-16) $\square$.
\end{abstract}

Ao contrário do que um leitor brasileiro poderia supor, grande parte dos trabalhos de Chayanov, assim como seus debates e correspondências teóricas, está em alemão e não em russo. Isso se dá pois, naquele momento, havia uma aproximação entre o mundo cultural dos dois países. Porém, essa aproximação seria interrompida com a formação das alianças em meio ao contexto dos antecedentes da Primeira Guerra Mundial.

Questão Agrária onde defende que com o advento da agricultura moderna o campesinato seria um setor que fatalmente desapareceria. Polemizou com Vladimir Lenin a respeito do papel da ação revolucionária.

${ }^{4}$ Narodnik, ou populistas, eram parte de um movimento político inspirado pela concepção de que através de uma revolução agrária levada pelo campesinato, que era entendido como o autêntico povo russo. O movimento ganhou força com o fim da servidão na Rússia durante o século XIX acreditando ser possível a partir disso a sua revolução. Ao serem reprimidos pelo regime czarista, passam a defender ações de assassinato de aristocratas russos, propagando a partir delas, o terrorismo. Posteriormente, muitos de seus adeptos integraram o movimento Social Revolucionário formaria o governo durante a revolução. 
Chayanov estudou na Academia Petrov, na Rússia, uma das mais prestigiadas do país, e fez alguns trabalhos em outros países como Alemanha, França, Itália, Inglaterra e Bélgica. Nesse sentido, acabou, por sua vez, por compreender e incorporar diferentes elementos da vida agrícola, em países com níveis e qualidades de desenvolvimento industrial distintos.

Por conta de suas viagens e seus estudos junto aos acadêmicos da Alemanha em sua estada em Berlim, Chayanov acabava sendo mais conhecido na Alemanha do que em sua própria terra natal (Love, 2009).

Entretanto, é durante o período revolucionário, tanto provisório quanto bolchevique, que Chayanov se notabilizou enquanto autoridade sobre o tema da agricultura. Isso se deu pela atuação de Chayanov na vida pública.

Chayanov trabalhou no Governo Provisório logo após a Revolução de Fevereiro de 1917, participou da Liga da Reforma Agrária onde se reunia com diversos autores a fim de resolver a questão agrária na Rússia. Cerca de um ano depois, foi presidente do Conselho da União Agrícola (1919-1920). Organizou um seminário para um debate a respeito da agricultura e, por fim, tornou-se membro do Colegiado do Comitê Popular para a Agricultura (1921-1922) (P. A. F. de Carvalho, 2014).

Ao tentar reorganizar o governo em meio à guerra civil, Lenin conclamou Kondratiev e Chayanov a exporem suas observações a respeito do que poderia ser feito na agricultura russa, no que seria o Comitê Estatal de Planejamento da URSS.

Ambos os autores responderam ao pedido de Lenin e enviaram trabalhos a respeito da condição da agricultura. Diante da relevância e do reconhecimento da competência dos autores, Lenin os convida a participar do governo bolchevique.

Foi então que Chayanov fundou e liderou o Instituto de Economia Agrícola da Universidade de Agricultura de Moscou por meio do Comissariado da Agricultura do Povo (NKZem), logo depois da revolução. Nesse momento, Chayanov já se notabilizava como uma grande autoridade do cooperativismo russo.

É essa a instituição que ficou também conhecida por ser a 'Escola de Organização e Produção' dentro do debate agrário na própria Rússia. Destacava-se por produzir estudos preocupados com o fenômeno da modernização do campo e suas consequências (Kojima, 2004) $\square$. 
Porém, ao contrário do que se estabelece em leituras brasileiras mais recentes, que haveria uma receptividade de Lenin para uma posterior perseguição stalinista, Franz Bourgholtzer aponta que, diante do quadro de uma iminente fome que o governo de Lenin não conseguiria superar, ele acaba oferecendo um espaço aos populistas russos para que conseguissem apoio externo. Contudo, o que Bourgholtzer demonstra é que a recepção de Lenin a Chayanov era dada por um interesse bastante pontual e não por uma tolerância intelectual à envergadura do pensamento de Chayanov, ainda que, inegavelmente, Lenin a reconhecesse.

Nesse sentido, a questão da formação da cooperativa agrícola pelo regime soviético ganhou importância naquele momento movida pela necessidade crucial de resolver diversos conflitos que o novo governo enfrentava. Porém, a visão dos socialistas em relação ao papel das cooperativas não enquanto uma organização de classe, mas uma que conseguisse ajustar o mercado em relação à demanda e à oferta, acabou se dando tardiamente. Quanto a isso, Yuli I. Kagarlitskii (1990) considera esse momento crítico para a compreensão da proposta cooperativa que alinhava a política pela cooperativização e a recuperação econômica:

\begin{abstract}
When Lenin started to consider agricultural cooperatives in 1923, not long before his death, he read six books by Chayanov before writing two articles on the subject. Lenin made two points in his articles. First, socialists should revise their attitude toward the cooperative movement, which they had previously rejected. They had to understand that, given the conditions of the New Economic Policy, the cooperative movement paved the way to socialism. Lenin's second point was that developing the cooperative movement in an ignorant, backward country had perforce to be a very gradual process over at least two decades, a process that would go hand in hand with a rising level of education among the people. (Kagarlitskii, 1990, p. 635) $\square$.
\end{abstract}

Diferentemente de Chayanov, Kondratiev já havia construído uma carreira próxima dos círculos sociais das esferas governamentais, e fizera contribuições estratégicas para a formulação das políticas econômicas soviéticas naquele momento. Até por conta disso, Kondratiev acabou por desenvolver uma proposição de ação governamental distinta, dada essa maior proximidade com o regime. Em 1922, Chayanov, mesmo diante do brilhantismo de seu colega, expõe algumas diferenças em 
relação a Kondratiev, por provavelmente temer a usurpação de seu cargo por ele (Bourgholtzer, 1999).

Além de reunir competências a fim de conseguir compreender as questões concernentes à produção e ao trabalho no campo, Chayanov foi capaz de teorizar a respeito de temas diversos relacionados à questão agrária e ao socialismo.

Uma passagem marcante da atuação de Chayanov ocorreu em 1921. Segundo Bourgholtzer, nesse ano as cooperativas eram virtualmente os únicos órgãos de comércio e distribuição de toda a Rússia que ainda detinham, diante das circunstâncias, alguma razoável operação. Antes da guerra, Chayanov juntara esforços com um amigo no Departamento de Estudos de Cooperativas na Universidade do Povo de Shanyavskii, conseguindo organizar um dos mais exitosos negócios cooperativos da Rússia, o Centro de Linho (1915), que conseguiu promover exportações por parte da economia soviética naquele momento bastante conturbado (Bourgholtzer, 1999, p. 16).

Talvez fosse por conta desse sucesso que Chayanov via com tanto otimismo a experiência das cooperativas. E é exatamente nesse ponto que se faz necessário observar uma mudança no sentido das obras de Chayanov, pois ele passa a considerar a cooperação como uma alternativa à incorporação da economia camponesa aos objetivos do socialismo.

Em seu trabalho A Teoria dos Sistemas Não Capitalistas (1924), Chayanov coloca os problemas fundamentais da questão. A obra tem como objetivo exposto, contribuir com a construção do socialismo. Porém, mesmo a concepção de socialismo por parte de Chayanov é bastante particular, revelando muito do que o influenciou em seu momento populista (Chayanov, 2014).

A premissa básica de Chayanov era a concepção de que o sistema capitalista moderno havia atingido todo o globo. Porém, mesmo alcançando as mais diferentes sociedades, Chayanov identificou que as relações não capitalistas sobreviviam, ainda que de maneira subordinada ao sistema capitalista. Vários ramos produtivos que estabeleciam relações com o sistema capitalista mantinham amplas relações não capitalistas.

Nesse sentido, é em meio a essa concepção, de que havia a existência dessas formas de produção não capitalista, que Chayanov procurou compreender a relação 
entre esses sistemas não capitalistas e capitalistas e, a partir dessa relação, passou a teorizar a respeito dos elementos fundamentais da constituição desses sistemas e sob quais conceitos esses sistemas seriam regidos. Assim, concebe, a partir da observação do campo russo que lhe é mais familiar, a teoria da economia camponesa.

Nesse ponto, o que se pode considerar é sua própria teorização a respeito dos sistemas não capitalistas acaba também por considerar a ideia de propor esse campo de construção em conhecimento econômico com o intuito da construção do socialismo. A concepção da economia camponesa seria interpretada posteriormente, como a via socializante da práxis revolucionária (Chayanov, 2014).

Contudo, assim como já visto em manifestações anteriores, como em 1922 numa de suas cartas pessoais, Chayanov já colocava que seu papel enquanto atuante nas políticas agrárias e econômicas do regime soviético parecia chegar ao fim, no sentido de que, diante do novo fôlego conseguido pelo governo revolucionário, em sua posição enquanto reconhecidamente não marxista, já via a possibilidade de ser destituído de seu cargo, ou em cair em desgraça diante da falta de apoio político real. É por isso que se pode interpretar que a publicação dessa obra se configura diante do momento em que ele pode ter procurado recondicionar sua situação quando ele já via a sua provável indisposição.

Com isso, não é incomum que em tempos de repressão se procure a liberdade e através de obras inspiradas na subversão através da arte. Em meio ao fechamento político do regime do comunismo de guerra, para ele, essa busca não foi diferente.

Ainda que seja uma parte bem menos reconhecida ou famosa de seu legado entre os autores ocidentais, entre 1918 e 1928, Chayanov escreveu diversos romances sob o pseudônimo "Botânico X”. Contudo, foi sob o pseudônimo de "Ivan Kremnev" que, em 1920, escreve o romance "A Viagem de meu irmão Alexei ao País da Utopia Camponesa".

A trama desse romance é a história de um homem que visita o futuro da Rússia e o seu posterior desenvolvimento. Haveria uma tomada de poder por meio de uma revolução que cumpriria outra etapa histórica. Esta seria resultado da derrubada do governo socialista, chegando-se então a uma forma superior de sociedade, em que um partido camponês conseguiria então fazer da sua utopia a realidade. 
Através disso, Chayanov colocava ponto a ponto as questões que elaborara teoricamente, além de relacioná-las com problemas que já se observava em seu presente.

A questão mais importante em relação ao tema do inevitável desenvolvimento do capitalismo e da destruição das outras formas de produção está relacionada com o fato de que Chayanov, ao observar em campo a organização da produção camponesa, notava um elo fundamental da organização do trabalho que se dá em torno da família.

Para Chayanov, a lógica produtiva que se mantém não capitalista se dá no interior de uma unidade doméstica, no caso a família. É a forma de apropriação dos ativos existentes no campo - como no caso a terra e os recursos e insumos disponíveis para produção via trabalho da atividade agrícola— que condicionam a sua ação laboral.

Porém, um elemento fundamental da exploração do trabalho enquanto seu componente institucional é o obrok, um pagamento de uma parcela do produto do trabalho do camponês ao nobre local, no caso uma instituição da servidão que em alguma medida persistia até o momento da realização de sua obra, e que de alguma forma dava os parâmetros dessa exploração. O pagamento do obrok durante a servidão modelou a conformação da unidade econômica camponesa com o seu elemento de troca externa.

Nesse sentido, é a partir da ideia de que há uma dinâmica demográfica familiar que organiza o trabalho e a produção na agricultura que Chayanov consegue então teorizar a respeito do que se conformaria como uma economia camponesa.

É assim que se consegue, por fim, compreender a ideia da cooperação contida na unidade econômica camponesa através do artel $^{5}$. O artel é o elemento que conforma a comunidade em seu sentido básico no sentido de regular e organizar um trabalho comum que era desenvolvido pelas famílias, mas em um âmbito suprafamiliar, no caso, no âmbito comunitário.

A economia camponesa é categorizada, em termos chayanovianos, como sendo uma economia não capitalista. As características que se consegue atribuir para que seja

\footnotetext{
${ }^{5}$ Artel instituição de organização da economia camponesa em seu nível comunitário, como no caso da propriedade comum (Mir).
} 
uma ou outra se dá pelo fato de que a relação existente entre a produção e a troca não se dão por meios monetários. Em outras palavras, Chayanov apreende a categoria dos processos de trocas visto em Marx, nos quais haveria uma lógica distinta da capitalista na produção e na distribuição dos bens.

Com base em observações e estudos empíricos, portanto, Chayanov consegue afirmar que há uma ideia de equilíbrio entre produção e consumo a partir de cada unidade produtiva econômica. A unidade econômica em um determinado espaço de produção teria voltado para o autoconsumo a sua produção. É nesse sentido que se concebe que a forma de apropriação em uma economia camponesa se dá por meio da ideia de consumo e usufruto dos bens localmente produzidos.

Porém, é a dinâmica da demografia familiar o ponto fundamental da evolução de um mercado de trabalho, bens e terras no interior da unidade camponesa. Nesse sentido, Chayanov compreende que há uma espécie de tamanho ótimo da unidade de produção agrícola e que esta corresponderia ao que se consideraria o tamanho de um estabelecimento de exploração familiar.

Da mesma maneira que se estabelece a produção e o usufruto da produção, o que se pode compreender do pensamento de Chayanov é outro ponto. É a partir da concepção de autoexploração do trabalho do camponês, dado o ponto de sua penosidade por ganho, que Chayanov concebe a fraqueza e a fortaleza da unidade de produção camponesa diante das unidades de produção capitalistas.

Partindo dessa ideia, uma vez atingida a satisfação da sua necessidade de reprodução familiar, o camponês acaba diminuindo a intensidade do trabalho empregado na atividade agrícola, tendo em vista que este o beneficiaria cada vez menos, dado o cada vez maior esforço. Contudo, mesmo a monetarização das relações econômicas na esfera da produção no campo acaba, por sua vez, não sendo suficiente para a transformação dessa lógica produtiva, já que em um âmbito doméstico de produção o que se estabeleceria seria uma lógica hierárquica de organização do trabalho e não uma lógica de trocas monetárias.

Nesse sentido, Chayanov observa que é a partir da penosidade e da autoexploração do trabalho camponês que a unidade econômica de produção camponesa acaba, por fim, tendo uma maior maleabilidade diante da escassez e da intensidade do 
uso da força de trabalho em períodos economicamente difíceis ou diante do aumento da concorrência. A troca monetária para a organização da produção tinha uma limitação, pois só se consegue pensar a reprodução dessa unidade a partir de uma categoria da economia moderna, que de alguma maneira impede ou mesmo limita a capacidade desta unidade de reagir a um momento de crise demanda ou de baixa produção (Chayanov, 2014).

Assim, o que se nota é que a produção desse campesinato acaba por de alguma forma subsistindo diante da competição do sistema econômico. Ou mais, pode se dizer que de alguma maneira é a existência de um sistema de produção não capitalista que se consegue manter a forma de produção do próprio capitalismo.

Danila Raskov faz um estudo a respeito do pensamento de Chayanov, considerando-o como um utópico dos anos 1920. Porém, ao fazer referência a uma crítica feita por Geoffrey Hodgson a respeito do caráter utópico tanto do socialismo, como do livre-mercado, o autor considera que ao contrário do que se conseguiria supor, é a motivação utópica da construção da visão de um socialismo agrário que Chayanov acaba por revelar em seus escritos acadêmicos, o potencial cognitivo das utopias presentes nas ideias econômicas de seu tempo (Raskov, 2014).

É por conta dessa observação que Chayanov acaba compreendendo a ideia do que se desenvolveria como agricultura familiar. Sua obra, nesse sentido, passa a contribuir com a ideia de que a cooperação comunitária, dada a mediação familiar, é o elemento fundamental da construção da viabilidade de uma agricultura que não se baseia exclusivamente nos elementos de formação de uma unidade produtiva estritamente capitalista.

Porém, ele também notava a fraqueza ou a possível inviabilização dessa produção do ponto de vista da inserção dessas unidades camponesas diante da própria expansão da lógica capitalista em um embate direto diante dos mesmos setores de atendimento da produção dessas por parte de seus demandantes. Os ingressos externos aos quais as unidades de produção capitalistas teriam em relação ao que se pode observar diante da relação de produção camponesa desequilibrariam a inserção da produção camponesa e acabariam, por fim, por excluir ou marginalizar essa produção de uma inserção no mercado. 
É a partir disso que Chayanov passa a compreender a ideia de uma via da organização cooperativa camponesa no sentido de superar as barreiras de mercado dessa produção diante da grande produção capitalista. Por sua vez, passa a considerar que é necessária a integração vertical da produção da unidade camponesa em diferentes setores da cadeia de produção e do beneficiamento desta para que se consiga aumentar os ingressos dos residentes na jurisdição desse espaço.

Em resumo, os pontos fundamentais da compreensão de Chayanov a respeito da sua própria concepção teórica passam por uma transformação absolutamente ligada a uma concepção da Economia Institucional. Raskov (2014) reduz os três pontos fundamentais sobre os quais se compreende que haja uma diferença entre os sistemas capitalista e socialista diante dos demais:

1 - plano de produção estatal;

2 - meios não econômicos de coerção;

3 - progresso técnico.

\begin{abstract}
In other words, the first question deals with the quality of information used for the production and consumption plan. The second question refers directly to the organizational structure of such a management system, in which a new hierarchy or nomenklatura comes into being. How is it possible to avoid redistribution of the social product in the sole interests of the nomenklatura or the new elite, thus discrediting the "ideal content" of the system? The third question that Chayanov asks focuses on labour incentives. On the one hand, the problem should be resolved by the application of consciousness and enthusiasm, as well as by material incentives. On the other hand, it is clear that an implementation of the plan can only be achieved by the use of noneconomic violence. Consequently, the problem of individual incentives and freedoms becomes ever more relevant. The pathos in Marx's early writings was based on the idea that the problem of alienation would be resolved in communism. In state collectivism or "coarse communism" the product of labour is alienated not in favour of the employer, but for the benefit of the state, which replaces the private owner (Marx, [1844] 2000). The lot of the hired labourer essentially remains unchanged, and exploitation remains. As we shall see, this is insightfully captured in Chayanov's utopia. (Raskov, 2014) $\square$.
\end{abstract}

Paulo Afonso de Carvalho (2014) notou que há um período entre as duas edições da mesma obra de Chayanov. Na primeira, a concepção de Chayanov é uma concepção dada por um escrito ou estudo de natureza epistemológica. Já na segunda edição, em que havia a necessidade de uma maior intervenção agrária por parte do governo, a obra de Chayanov carrega traços de um material de difusão de ideias gerenciais, 
características de um manual.

Nesse sentido, nota-se mais uma vez que há uma adequação à pressão do momento da vida social russa que se expressa na obra de Chayanov. A interpretação de sua obra em relação aos seus significados enquanto obra para a compreensão aplicada de uma determinada política deve ter em si também elementos para identificar a forma como Chayanov expressa uma reação aos constrangimentos externos diante do fechamento dos direitos civis e políticos do regime soviético no momento em que escreveu suas obras mais importantes.

Esse ponto não é inédito pelos intérpretes mais recentes do legado de Chayanov. Raskov, ao interpretar Chayanov, aproxima-o de Alexander Bogdanov ${ }^{6}$, um economista contemporâneo a ele, adepto ao bolchevismo, que também tratava de transformações utópicas em seu momento. Raskov considera que Chayanov e Bogdanov foram os economistas que criaram as mais importantes utopias literárias.

Ao tratar da relação entre o trabalho científico de Chayanov e suas obras literárias, Danila Raskov afirma que seu caráter teórico é expandido por uma forma de inspiração dada por sua produção artística e cultural. A manifestação da defesa das utopias na produção cultural de Chayanov seria impulsionada, segundo Raskov, por conta da inconformidade com a política do regime bolchevique e que se acentua com a política da coletivização. É neste momento que a perseguição a mando de Stalin se dará com a sua perseguição, prisão, exílio e morte.

\subsection{A TRANSMISSÃO DE SUA OBRA ATÉ OS DIAS ATUAIS}

Porque Chayanov era um autor proscrito na União Soviética, suas obras perderam espaço nas leituras feitas no país durante esse período. Porém, através de contatos com exilados russos e de seu impacto nos países do leste Europeu que tiveram influência do debate em alemão, puderam ser acessadas.

Na década de 1960, com a desestalinização, o cenário de maior abertura proporcionou uma maior liberdade de ação e expressão, não apenas nas artes, mas

\footnotetext{
${ }^{6}$ Alexander Alexandrovich Bogdanov (1873-1928) foi um economista russo bolchevique. Porém, era também um poeta e manteve um controverso debate com Lenin a respeito do papel da cultura na revolução.
} 
também na produção cultural como um todo. No cenário internacional, um dos autores responsáveis por manter esse legado é Teodor Shanin (2009).

O historiador Joseph Love (2009) traça um paralelo do legado de Chayanov e da introdução de sua obra no Brasil e na Romênia. Love afirma que houve um relativo desconhecimento de sua obra no Brasil por conta da falta de acesso aos seus textos e pela incorporação da interpretação de A Questão Agrária de Karl Kautsky, maior líder da social-democracia alemã no período entreguerras polemizando com Lenin dentro do campo marxista (Love, 1990, 1996, 2009a).

Como aponta Love, ao contrário do que aconteceu na Romênia, onde, a partir de 1925, o estudo dos trabalhos de Chayanov tomados em língua alemã inspirou a formação de um Partido Camponês Romeno, no Brasil Chayanov, assim como em geral o debate entre os marxistas e os populistas, era praticamente desconhecido. Porém, é em meio a um também relativo desconhecimento do próprio marxismo que, no Brasil, houve um espaço para que surgissem interpretações heterodoxas em relação ao marxismo, como no caso da obra de Caio Prado Jr.(Love, 1990, 1996, 2009b).

A esse exemplo, as obras de Ellen Woortmann e Klaas Woortmann são fundamentais para a difusão da teoria chayanoviana no Brasil. Influenciaram os estudos na área de antropologia social ao incorporar a lógica familiar da produção e do consumo e superar as interpretações marxistas dominantes à época (E. F. Woortmann, 1983, 1995; K. A. A. W. Woortmann, 1983).

Um dos estudiosos da agricultura brasileira é Ricardo Abramovay, que propõe conceitos sobre a Agricultura Familiar e a sua multifuncionalidade. Porém, ele próprio faz uma reflexão a partir da economia a respeito de um dos romances de Chayanov, justamente o A Viagem de meu Irmão Alexei ao País da Utopia Camponesa.

Existe atualmente uma vasta literatura comentando as teorias de Chayanov sobre o campesinato e já tratei o tema em outro trabalho (Abramovay, 1992). Todavia, nem sempre é colocado em destaque que ele não era o teórico do isolamento camponês. Ao contrário, o último capítulo de sua obra maior preconiza o cooperativismo e a integração vertical, citando explicitamente o exemplo da Dinamarca como forma mais eficiente de construção do socialismo na agricultura. Chayanov já antevia o desastre que ocorreria caso predominassem as teses que sustentavam a integração horizontal, ou seja, a formação de grandes unidades coletivas. Não que ele fosse contra as grandes fazendas coletivas, pois, durante o período em que, sob o regime soviético, ele ocupou responsabilidades na área de agricultura da Academia de Ciências 
(o que não deixa de ser surpreendente para alguém que tinha sido viceministro de Kerenski) chegou a calcular o tamanho ideal que poderiam ter algumas unidades com esse tipo de organização. O que Chayanov não queria que se perdesse era exatamente a grande organização social já existente na Rússia, tanto entre os próprios camponeses quanto entre os agrônomos. (Abramovay, 1998, p. 72-73).

Já Flávio Pinto Siabato (2009) aborda a elaboração da ideia da sobrevivência da economia camponesa baseado em diversos autores, incluindo Chayanov, a fim de entender como compreender a sobrevivência desse tipo de economia com a questão da aversão ao risco. Siabato entende que há uma natureza de sobrevivência nos camponeses, valendo-se da interpretação de distintos modelos dessa economia e adaptação de teorias sobre o comportamento racional e otimizado na busca pela resolução de seus interesses (Siabato, 2009).

Por fim, o mais relevante desses trabalhos na defesa da teoria de Chayanov é o de Jan Van Der Ploeg (2013) Peasants and the Art of Farming: A Chayanovian Manifesto, em que o autor traça a trajetória dos estudos sobre Chayanov e as diferentes experiências que empiricamente demonstrariam a atualidade e a necessidade da retomada dos estudos chayanovianos. Assim, Ploeg apresenta a ideia de que existam tradições do pensamento chayanoviano, representadas pela interpretação das diferentes realidades agrárias por meio de sua teoria (Ploeg, 2013).

É partindo dessa posição que Ploeg defende uma via de recampesinização como forma de aperfeiçoar tanto a produção agrícola, como a sua correspondência no nível de bem-estar do equilíbrio social. Ao expor os casos mais avançados da agricultura e desse processo de recampesinização, o autor trata da possibilidade de uma nova forma de recampesinização que implique reequilibrar a relação da função de utilidade ao produzir, com a do controle da autoexploração do trabalho (Ploeg, 2013).

\subsection{IVAN VASILY EMELIANOFF (1880-1945)}

Ivan Valisy Emelianoff (1880-1945) foi um economista russo que se concentrou em estudar cooperativas. Diante das rápidas e radicais transformações ocorridas na Rússia, Emelianoff passou a tentar compreender em que medida há uma forma de atuação no sentido de abarcar com a própria movimentação de bens a questão da 
cooperação. Sem dúvida alguma, a sua maior contribuição foi a de delimitar o caráter epistemológico do estudo da cooperação no campo da economia, mais precisamente nos estudos das organizações.

Muito pouco se sabe sobre a vida de Emelianoff, tanto em relação à sua passagem nos Estados Unidos e na Inglaterra, quanto ao seu retorno à Rússia, Kharkov (atual Ucrânia) e seu exílio definitivo nos Estados Unidos. Emelianoff foi "um dos altos representantes de uma cooperativa de crédito". Também estudou e lecionou em Praga, onde teve muito reconhecimento de seu trabalho sobre cooperativas.

Antes da revolução e mesmo em meio aos primeiros anos do regime soviético, Emelianoff teve uma vida corporativa de expressão notável. Foi presidente do Zemtsvo Provincial do Banco de Kharkov, e também diretor do Selosoyus Ltd., uma agência de cooperativas russas na Europa Ocidental baseada em Londres, debruçando-se sobre assuntos e temas do cooperativismo, entre os anos de 1920-1921.

Porém, os poucos registros sobre sua vida e obra revelam bastante a respeito da estatura de suas concepções teóricas, ainda que diante de elementos muito mais notabilizados por suas posições no meio cooperativista. Ao contrário de Chayanov, Emelianoff teve uma proximidade muito maior com o mundo anglo-saxão, morando na Inglaterra e nos Estados Unidos, fato que condicionou o apelo à sua contribuição teórica, já que passaria por uma mediação de seus posteriores leitores em relação a um mundo até certo ponto estranho aos olhos dos observadores ocidentais, principalmente no ambiente acadêmico norte-americano.

Depois de sua primeira estada nos Estados Unidos, com a oportunidade de conhecer esses diversos estados norte-americanos, Emelianoff, ao retornar à Rússia, acabou, assim como muitos dos líderes e representantes dos movimentos cooperativistas, tendo suas vidas afetadas com as disputas políticas em meio à Grande Guerra. A situação se deteriorou quando houver revolução de fevereiro e de outubro, que acabam transformando a relação entre o governo estabelecido, a guerra e as organizações de produção.

Com isso, não diferentemente de seus pares, Emelianoff se viu forçado a fugir da Rússia devido ao acesso bolchevique ao governo. Ao observarmos o destino de seus pares, como Chayanov, nota-se que ele, que não teve militância ou ativismo — senão no 
cooperativismo enquanto um movimento que desenvolveria posteriormente a sua neutralidade, ou seja, que não tomaria parte em nenhuma das forças diante da guerraparece ter entendido rapidamente a gravidade das transformações que se configuravam na política soviética do ano de 1926 quando Stalin fortalece sua posição no governo e afasta os outros líderes revolucionários.

É em meio a isso que Emelianoff e sua esposa vão para os Estados Unidos em 1927, no mesmo momento em que Chayanov começa a sentir o assédio das medidas do governo stalinista. Para recomeçar sua vida profissional, passa a lecionar como professor visitante na Universidade Rutgers, onde então procurou dar continuidade à sua carreira acadêmica.

Entretanto, por uma suposta indisposição com o corpo docente, acaba sendo dispensado da Rutgers. Seguem passagens suas por alguns órgãos que atuavam na recuperação da economia norte-americana, como a National Recovery Administration (NRA) e a National Research Program (NRP).

Os anos de 1937 e 1938 são muito difíceis para Emelianoff, já que estava desempregado. Ele acaba por ser convidado para trabalhar no Bureau of Labor Statistics como analista, e, finalmente, é contratado pelo Temporary National Economic Committee (TNEC) para reedição de relatórios sobre cooperativas de associações de varejistas e associações de produtores agrícolas.

Ingressa no doutorado e avança em seus estudos sobre uma teoria econômica e científica sobre a cooperação. Foi nesse momento em que Emelianoff pôde então se concentrar em teorizar a esse respeito que escreve uma obra, The Economic Theory of Cooperation que, apesar de haver influenciado diversos autores, só foi publicada postumamente por sua esposa em 1945.

Ao compreender a cooperação através de um aporte científico, com um método de verificação tanto do uso de termos e conceitos, como de dados de natureza empírica, Emelianoff passa a ser considerado um herético pelos pensadores ou tradicionais teóricos que a rigor são doutrinadores do cooperativismo, sobretudo àqueles ligados ao campo socialista. Uma diferença fundamental em relação a isso é que Emelianoff observava que havia uma inadequação da proposição intencional ou do objetivo político de cooperativas, como das fundadas através dos princípios rochdaleanos, que pouco 
compreendia sobre os aspectos econômicos da cooperação, assim como a sua relação com a própria viabilidade em meio a um mercado competitivo.

Emelianoff foi o primeiro autor a de fato propor uma teoria desenvolvida com rigor em relação às empresas cooperativas. De fato, ao observarmos as categorias propostas por ele observamos sobre a relação de negociação e barganha da organização cooperativa e de seus membros colocando de lado uma adesão simplesmente voluntarista, mas sim diante da questão do reconhecimento de interesses no exercício da negociação.

O ponto fundamental da questão é que há uma concepção dos pensadores ou doutrinadores do cooperativismo em seu momento que é dominante. Isso se expressa no volume de publicações e objetos de debate a respeito da cooperação que se espalham no espaço do domínio científico.

Emelianoff não estava alheio a esse momento. Porém, o que se faz necessário então é compreender a partir de quais autores —que não esses doutrinadores, ativistas e quaisquer que sejam a natureza de suas ações e obras - ele foi capaz de constituir a sua própria teoria da cooperação.

Ao construir sua teorização, Emelianoff parte de um método baseado um levantamento de proposições autores da literatura existente e submetê-los a um teste. Esse teste buscava localizar elementos lógicos que pudessem embasar suas primeiras afirmações. Assim, se houvesse proposições contraditórias, Emelianoff acabava por tomá-las, a fim de extrair os elementos constitutivos de sua teoria.

Emelianoff acaba reunindo, ao longo da sua vida, contatos com proponentes do cooperativismo dos mais variados. Ainda que possam ter tido alguma influência em movimentos e ativismos cooperativistas, Emelianoff compreende-os dentro do debate no qual se apreende por meio de categorias econômicas a questão ou não da realização da cooperação enquanto um fenômeno econômico.

Sua crítica em relação ao que se compreende da parte de integrantes desses movimentos cooperativistas que pretendiam defender teses dentro do âmbito de um afã cientificista, pode ser observada também diante de outros proponentes do cooperativismo. Assim, para Emelianoff, muito do que se faz nos movimentos cooperativistas -e impetuosamente aos seus cânones ou maiores representantes-, 
nesse sentido acaba se tornando um trabalho de propaganda, como ele expõe ao tratar de Robert Owen ${ }^{7}$ :

It is indeed hardly explainable that in spite of such a clear declaration of Owen himself, orthodox interpreters of cooperation persistently obtrude upon him the unwelcome 'glory' of the fatherhood of the cooperative movement. The explanation of this paradoxical misinterpretation of the historical fact, however, is very simple, since all the followers of the traditional doctrine on cooperation were not primarily interested in the economic analysis of the cooperative problem but were mostly concerned with propaganda of socialism. (Emelianoff, 1995, p. 6-7).

Emelianoff via a cooperativa como uma organização resultante da integração vertical de diferentes setores ligados a uma determinada atividade econômica. E, não apenas para os estudos sobre organizações cooperativas, a obra de Ivan Emelianoff representa uma pedra angular para os estudos da Teoria da Organização Industrial como um todo.

A retomada da teoria de Emelianoff para uma interpretação que se faz diante de um arcabouço teórico dentro dos parâmetros da Nova Economia Institucional acaba por ter desajustes nesse sentido. Ao elaborar sua teoria, Emelianoff trata do conceito de "empresa", o que constrange essa aproximação necessária com o que se trata enquanto firma pelos autores mais recentes.

É nesse ponto que se observa que há uma diferença de natureza do estudo do cooperativismo. O trabalho de Emelianoff expõe que, ainda que se tenha tentado construir conhecimento a respeito da cooperação, o que há na verdade é um estudo sobre o pensamento e os movimentos cooperativistas, em que a cooperativa enquanto organização é tomada como o meio de solução de falhas de mercado ou como instrumento de reforma social; ou movimentos coletivistas, como socialistas das mais diversas origens, em especial dos marxistas, anarquistas, em que a cooperativa enquanto organização é a forma de operação da transformação revolucionária, seja de forma gradual, seja enquanto instrumento de organização de classes na direta luta política.

Com isso, o trabalho de Emelianoff acaba dando origem a uma tradição de

\footnotetext{
${ }^{7}$ Robert Owen (1771-1858) reformista social britânico que propôs a melhoria da situação de vida dos operários de fábrica. Fundou uma comunidade nos Estados Unidos, New Lanarck, onde idealizava a superação dos problemas sociais através do compartilhamento do trabalho e de seu usufruto. Ainda que não tenha tido êxito, atribui-se a Owen a inspiração a movimentos cooperativistas posteriores, como os Pioneiros de Rochdale na Inglaterra.
} 
estudos sobre o cooperativismo bastante peculiar, mas que tenta compreender a relação de uma ação coletiva diante de um problema social de mercado. Isso se torna relevante na discussão sobre o cooperativismo no Brasil, pois, grande parte do debate brasileiro está marcado pela compreensão doutrinária do cooperativismo, onde se procura teorizar a respeito da questão da transformação social que a cooperativa deve então empreender em vez de, por fim, representar e defender os interesses dos membros associados que a compõem (Emelianoff, 1995).

O livro de Emelianoff se divide em três partes nas quais ele tenta localizar e delimitar os debates propostos em cada uma. Cabe aqui entender que a compreensão de Emelianoff é basilar enquanto proposta para separar a literatura cooperativista enquanto formas de pensamento e doutrina do cooperativismo e os estudos sobre a cooperação que não necessariamente advogam por uma via ou intervenção cooperativista.

Emelianoff demonstra que há uma atribuição errada feita aos cooperativistas. No caso de Robert Owen, o autor expõe o problema de diversas interpretações difundidas a respeito do seu papel enquanto "fundador" do movimento cooperativista.

Segundo ele, Owen foi primeiramente reverenciado e depois, com o fracasso de suas experiências e ideias, acabou sendo ao final humilhantemente motivo de zombaria. Emelianoff coloca que Owen, um interessantíssimo sonhador, não se atribuía esse papel; foi apenas após a sua morte que Owen foi alçado ao posto de mártir do movimento cooperativista.

Cabe lembrar que Emelianoff acaba por compreender a questão do pensamento de Louis Blanc ${ }^{8}$ a respeito de sua interpretação a respeito da economia e da sociedade. Nesse sentido, ele afirma que Blanc e os blanquistas acabam censurando a competição do propósito da ação econômica como sendo um elemento de subversão da ordem.

A interpretação de Emelianoff acerca do estado dos estudos teóricos sobre a cooperação em seu tempo divide-o basicamente dois grupos: um, o que vê a cooperação estritamente em seu aspecto econômico, e o outro, veria o problema, segundo o autor, inteiramente. Por fim, ele afirma que falta em ambos, do ponto de vista analítico, uma abordagem econômica.

\footnotetext{
${ }^{8}$ Louis Blanc (1811-1882) foi um político socialista francês que, diferentemente de personalidades de sua época, passa combater e vislumbrar o fim do sistema capitalista.
} 
Em relação ao primeiro, vale observar que ele coloca Tugan Baranovski com o seu livro Social Basis of Cooperation como um ponto de partida desses estudos. Baranovski observa as diferenças entre cooperativas proletárias, cooperativas camponesas e cooperativas de classes médias urbanas, já que esses grupos consideram interesses distintos em relação ao que se construiria como um interesse comum que norteie a manutenção da cooperação (Emelianoff, 1995, p. 16).

As concepções de Tugan Baranovski9 foram amplamente difundidas no debate soviético sobre a formulação das políticas agrárias. Nesse sentido, o que se pode compreender é que, ao contrário dos dirigentes e de seus pares, Emelianoff não compactuava da questão da via da cooperativa da construção do socialismo. A organização cooperativa se trata, para Emelianoff, de um exercício de livre-iniciativa, não um voluntarismo ou uma meta específica para um determinado modelo de sociedade emancipador.

Emelianoff desenvolve a partir de seu método de teste e verificação uma concepção das características da formação das relações de mercado. Passa a compreender que é através da organização, enquanto um agente de produção, que se dão as correções de mercado.

O autor compreende que é diante das externalidades negativas surgidas das falhas de mercado que as organizações se desenvolvem a fim de resolvê-las. Sendo assim, ele também supera a caracterização hedonista da atribuição da ação individual.

Com isso, Emelianoff apresenta as organizações, como pensada por autores de sua bibliografia como:

1 - instituições de caridade, que acabam tendo pouco efeito na estrutura de mercado; 2 - coparticipação que acaba não pretende substituir as relações de remuneração salarial do sistema, tendo o propósito de motivar e estimular trabalhadores mais diligentes; 3 - sindicatos, que acabam por ter um elemento complicador econômico, como no caso de monopolizar o fator trabalho nas relações de produção;

\footnotetext{
${ }^{9}$ Mikhail Ivanovich Tugan-Baranovski (1865-1919) foi um economista russo teórico da cooperação a partir do marxismo. Segundo o seu pensamento, a cooperação se dava por conta da relação social, fundamentada na condição de classe, que propiciava a cooperação e a organização de cooperativas como organizações dos trabalhadores.
} 
4 - organizações de previdência social, como as mutuais, sociedades de ajuda, associações de pensionistas e etc.;

5 - as cooperativas que representam "a mais complicada e o mais alto tipo de corretivo"

(Emelianoff, 1995, p. 17).

É a partir da ideia da cooperação como uma articulação interessada e que em alguma medida comporta interesses contraditórios que ele apresenta uma funcionalidade das relações sociais, e de poder, que podem se formar na cooperativa, assim como a sua potencialidade de organização de serviço social. Assim ele expõe uma das características da cooperação:

Cooperation, believes Mariani, is also capable to a certain degree of softening and of abbreviating social conflicts which result from economic differentiation. Economists, remarks Mariani, usually emphasize the advantages of economic differentiation and underestimate its drawbacks. Meanwhile, every act of exchange is in some sense a conflict of two egoisms; all the social conflicts between capital and labor are nothing but a struggle between buyers and sellers of labor's services. Free competition can restrict, to some extent, these defects of economic differentiation, but cannot eliminate them. Legal control is also helpless. Socialism, supposedly, has to eliminate them however, at too high a price: it brings in an omnipotent bureaucracy and, along with social conflicts, eliminates every sign of individual initiative and freedom (Emelianoff, 1995, p. 22).

É nesse sentido, portanto, que se pode dizer que há uma compreensão bastante peculiar por Emelianoff com o intuito de observar a configuração da atribuição geral dos estudos da cooperação. Dessa maneira, Emelianoff entende que os documentos escritos e a literatura dos estudos sobre a cooperação têm três naturezas:

a) a primeira, de estudos de natureza social reformista, que tem como objetivo de fato a transformação social tomando a via da organização cooperativa como um elemento transformador da própria sociedade;

b) a segunda, de natureza descritiva, se trata de um esforço observar as dinâmicas sociais e a sua compreensão enquanto um fenômeno dado na realidade;

c) a terceira, de estudos teóricos, ou que, no caso tem como objetivo a construção de um conhecimento determinado a respeito da cooperação.

Emelianoff reúne o conteúdo das diversas definições a respeito da cooperação existentes até então, totalizando 23 delas. Além disso, reúne, a partir dos autores dessas definições as características do que seriam as cooperativas, que totalizam as 46 a seguir: 
1 - A cooperativa é uma empresa

2 - A cooperativa é uma união de pessoas

3 - Associações de caráter voluntário

4 - Associações de ilimitado número de membros

5 - Princípio de igual votação

6 - Iguais direitos e responsabilidades dos membros

7 - Função de assistência mútua

8 - Associações cooperativas foram originadas pelos fracos

9 - O conjunto dos membros deve ser restrita em associações cooperativas

10 - Igualdade é princípio básico da cooperação

11 - Serviços são providos a preço de custo em cooperativas

12 - Os interesses do trabalho são básicos em associações cooperativas

13 - Cooperativas securitizam suas poupanças para seus membros

14 - O uso de métodos de negócios de larga escala são o objetivo da cooperação

15 - Cooperativa - organização específica de trabalhadores e pequenos homens de negócios

16 - Autogestão é caraterística essencial das cooperativas

17 - Cooperativas são operadas para os seus patrões

18 - A organização cooperativa é uma unidade social

19 - Os dividendos pagos pela cooperativa são limitados

20 - Nenhum dividendo em ações é pagável em cooperativas

21 - A proporcionalidade é um princípio básico da cooperação

22 - O voto proporcional é um princípio cooperativo

23 - O apoio estatal é rejeitado por princípio

24 - $\mathrm{O}$ apoio estatal é assumido pelas cooperativas

25 - A eliminação do lucro - missão das cooperativas

26 - A busca por lucros é uma característica inerente de cooperativas produtivas

27 - O espírito não egoísta é característica básica da cooperação

28 - Motivos hedonistas baseiam o comportamento econômico das cooperativas

29 - Interesses comuns dos membros nas associações cooperativas

30 - Comércio conjunto: característica das associações cooperativas 
31 - As cooperativas são organizações de compradores e vendedores

32 - Membros apenas são intitulados para o uso serviços da associação

33 - O número da participação de propriedade de um membro individual é limitado

34 - A melhoria dos preços é o objetivo das associações cooperativas

35 - A função primária da associação cooperativa é promover o trabalho econômico de seus membros

36 - Princípios equitativos são básicos em associações cooperativas

37 - O objetivo de associações cooperativas é oferecer serviços e não buscar lucros

38 - A função básica da associação de marketing (como incentivo ao comércio e não como se concebe hoje - devo procurar um termo mais apropriado) é a estabilização da produção

39 - A função das cooperativas de marketing é a estabilização do marketing

40 - As cooperativas representam a correção do sistema de distribuição existente

41 - Os ganhos são divididos proporcionalmente ao volume de negócios feitos por cada membro individual da associação

42 - As cooperativas são operadas por patrões

43 - Dividendos por apadrinhamento (clientelismo) - é uma característica de associações cooperativas

44 - Todos os membros são empregados na cooperativa

45 - Todos os empregados nas cooperativas são seus membros

46 - Patrões tomam benefícios e dividem perdas em associações cooperativas

Ao se observar a reunião das características das associações cooperativas reunidas por Emelianoff, nota-se que há várias delas que são contraditórias, eliminatórias e excludentes. Pode-se dizer que muitas dessas características são atribuídas sem partir de nenhuma análise embasada em observação ou método claro.

Porém, ao contrastar e expor as concepções contraditórias entre si é que se faz então o seu teste de sentido, para que se consiga, a partir desse exercício, extrair os supostos básicos da formação do pensamento e da concepção da cooperação. É por meio desse teste que Emelianoff empreende retirar a subjetividade presente nas concepções de proponentes, ativistas ou militantes do cooperativismo e de suas falácias sobre a 
cooperação, a partir da construção de uma teoria puramente econômica sobre a cooperação.

De fato, o que o próprio Emelianoff acaba por perceber é que a construção do ideário da cooperação revelado pela simples reunião dessas atribuições é que, apologéticas ou críticas à organização das cooperativas se tratam de atribuições indubitavelmente normativas. O autor coloca:

\begin{abstract}
For the most part, the essentials represent partial generalizations from the experience of certain groups of cooperative organizations and therefore they do not cover the cooperative problem in its entirety. Thus the tests propounded by the American economists relate primarily to the marketing associations; those of French and English interpreters are inspired by experiences with the consumers' stores, while Russian, German and Swiss students quoted deduced their 'principles' mostly from the organization and work of the cooperative credit and purchasing associations predominant in their respective countries. Hence, almost inescapable one-sidedness and incompleteness of the concept of cooperative association described in the definitions under discussion; in most cases such incompleteness is due not so much biases, as to lack of actual knowledge and to an insufficient field of observation. (Emelianoff, 1995, p. 30).
\end{abstract}

O conceito de empresa discutido em Emelianoff é entendido por ele como uma organização econômica aquisitiva e que abarca, ou procura abarcar um todo. É no sentido da interação no sistema de mercado que a aquisição se dá.

Para Emelianoff, considerar a organização cooperativa como uma empresa ou como uma associação é um equívoco. Para ele, é necessária, para compreender os elementos constituintes da organização cooperativa, a ideia de que a organização cooperativa é um agregado de unidades econômicas, empresariais ou domésticas, no sentido de que possam corresponder a uma determinada finalidade.

Com isso, Emelianoff introduz o conceito de "unidade econômica" para conceber, por fim, a ideia de que o agregado econômico formado por meio delas poderia derivar formas posteriores, como no caso ele entenderia de uma forma geral a organização cooperativa.

Cabe então compreender que há uma diferença fundamental para a compreensão o tema da cooperação por parte de Emelianoff que é a formação ou não da unidade econômica a partir de fatores que se constituam na sua interação. Assim, tanto a caracterização de uma empresa quanto a dos tipos de cooperativas acaba por ser 
retomada em um sentido no qual a primeira ação coletiva é fundacional da própria associação.

Assim, a questão da operação das organizações cooperativas e sua composição estratégica, enquanto associações, passa a compreender a questão da formação de fusões entre as unidades do agregado conformando outras unidades, de distintas naturezas. Além disso, Emelianoff delimita a questão diante de atribuições como falácias de compreensões sociológicas rasas e a ideia de que a associação cooperativa seria uma organização econômica dos desprivilegiados ou subalternos.

Por fim, por conta de uma preocupação clara em operar conceitos econômicos teóricos da cooperação, Emelianoff acaba por rejeitar a ideia de pseudocooperativas, como sendo unidades destituídas de cooperação. A suposta degeneração tem a ver com uma determinada tradicional filosofia da cooperação que, apesar de denotar sintomas do mau funcionamento da associação cooperativa, acaba não tendo um significado real (p.253). Emelianoff considera que:

The cooperative problem has a bewitching power: it hypnotizes those who approach it. I t has many zealots and few students. Having always been reverently treated, it appeals to emotions more than to reasoning. The attitude of the European interpreters toward cooperation has been nearly sacred and even the description of the cooperative movement has been customarily done in the Biblical terms: to wit, cooperation has its Apostles and Fathers, its Bibles and Gospels, its Creed and its Revelation. Such an emotional approach has had certain bearing even upon the leading economists who since the time of J. S. Mill attempted to touch the cooperative problem Alfred Marshall pointed out merely great faith embodied in the cooperative movement but otherwise passed over this problem; Prof. Ch. Gide devoted all the efforts of the School of Nimes" to propaganda of a somewhat foggy philosophy of cooperatism; Prof. Franz Oppenheimer reduced his interest in the problem to emotional glorification of the Siedlunggenossenschaft, and Prof. M. I. Tugan Baranovsky did not hesitate to discern the mortal body of cooperative organizations from their immortal soul. Many other outstanding economists have made more or less cursory remarks on cooperative associations repeating unquestioningly the established opinions on the subject with all their misleading and confusing implications. It may be said that such an emotional and such a non-critical approach to the cooperative problem, with emphasis on its socio-reformistic mission, is institutionalized in Europe.

American students of cooperation being comparatively free from emotionalism made a considerable contribution to the knowledge of the economics of cooperation with almost exclusive emphasis, however, on the business efficiency of these organizations. Neither of these two avenues of approach can lead to the disclosure of the economic character of the cooperative body, i.e., neither can throw light on the distinguishing characteristics of its structure and its functional peculiarities. (Emelianoff, 1995, p. 245-246) $\square$. 


\subsection{A TRADIÇÃO DE INSPIRAÇÃO EM EMELIANOFF}

Assim como Chayanov, Emelianoff inspirou uma longa tradição de estudos. Porém, diferentemente de Chayanov, que teve o estudo de suas obras difundido a partir de diversas formas, o estudo de Emelianoff influenciou os da América do Norte, sobretudo nos Estados Unidos da América.

O primeiro dos estudos a incorporar sua teoria nos estudos sobre cooperativas foi $A$ Theory for Cooperation (1947) de Franz Robotka. Porém, ele avança a partir dos termos de Emelianoff no sentido de compreender a especificidade das atividades coordenadas e das decisões de grupo diante da atribuição de um tipo econômico distinto (Robotka, 1947).

Já Richard Phillips se apropria das contribuições de Emelianoff e Robotka a respeito da relação entre a forma da associação e o sistema de input e output da atividade funcional da cooperativa para a geração de um modelo. Porém, Phillips parte da ideia de que a coordenação das ações para um determinado propósito econômico, compreendido como uma forma de cooperação, não deve, para fins analíticos, ser estendido a qualquer outro nível da atividade desses agentes individuais agregados (Phillips, 1953) $\square$.

Assim, ao constituir seu modelo, acaba por observar que por trás das relações sociais envolvidas há uma relação de valor que se dá na interação entre os agentes que cooperam e a busca apenas de seu próprio retorno. Assim, descreve a relação pela qual, através do seu modelo, ele reconhece a inviabilidade de que agentes econômicos formem uma cooperativa no sentido de apenas buscar os rendimentos dela, mas sim que há uma intermediação técnica da operação da coordenação que os impede de apenas extrair essa renda, como explica aqui:

As an economic institution, the cooperative association is not an organization of persons, either as laborers, as capital contributors, or as patrons, for that matter. It is an organization, as Emelianoff and Robotka both point out, of sovereign economic units-firms or households. Although it is descriptively correct to say that a cooperative association is a business organization owned and controlled by its patrons and operated for their benefit as patrons, such a statement contributes nothing to the understanding of the economic structure of the cooperative. Capital, and even labor, may be involved in 
patronage; but patronage, per se, is not a productive resource capable of earning an economic return in the production of goods and services. Rather, the value of patronage to a given firm is reflected in the nature of the demand and supply functions faced by that firm. It is not possible t'o organize an economic system from the standpoint and for the benefit of the patron, "as the controller of a given factor of production. It is possible for firms jointly to organize and operate a common plant with the idea of maximizing the economic returns to each of the individual associated firms. (Phillips, 1953, p. 75).

Outro exemplo da importância da obra de Emelianoff não se dá somente pelos que se apropriam de sua teoria, mas também pelo fato de que sua interpretação da cooperação seja combatida. Nesse papel estão Peter Helmberger e Sidney Hoos (1962) que, ao proporem o estudo de empresas cooperativas e de suas respectivas firmas, tomam a perspectiva da teoria das organizações como sua ferramenta explicativa na medida em que, justamente, reconhecem a questão de seu controle administrativo como meio de efetivo controle de suas ações, sugerindo para tal um modelo corporativo de empresas (Helmberger \& Hoos, 1962).

Porém, diferentemente de Helmberger e Hoos, o primeiro trabalho a tentar relacionar a teoria econômica da cooperação, a teoria das firmas e a teoria das organizações é o de Randall E. Torgerson (1971) Alternative Structural Approaches to Farm Bargaining: A Cooperative Systems Model. Em um esforço amplo de compreensão do problema desse tipo de agente econômico, Torgerson recorre à teoria de Olson para compreender, antes da própria concepção econômica, a relação da ação coletiva (Torgerson, 1971, 1977). Posteriormente, Torgerson (1977) retoma a questão da própria atividade do setor agrícola e de suas especificidades, para observar o fenômeno da cooperação, tomando para isso o termo farmer cooperatives. É por meio de um esforço analítico integrador dessas perspectivas teóricas que ele afirma:

Cooperatives are, in practice and theory, an off-farm extension of the farm firm, an integral part of the farming enterprise that allows farm operators to extend themselves vertically to one more stages in the marketing channel. The premise for cooperation lies primarily in the structural relationship of farm operators, characteristically atomistic in nature (many in number and relatively small in size) compared to those with whom they buy and sell (few in number and relatively large in size). Without ability to organize, farmers are powerless to deal with firms that are increasingly characterized by fewer numbers, larger market shares, more diversification in product lines, and greater vertical integration of operations. The changing market structure of agriculture, a prime motivator in early organizing efforts associated with the 
emergence of commercial agriculture, a remains today the underlying rationale for cooperative efforts by farm operator. (Torgerson, 1977, p. 92).

Ao tratar da questão levantada por Emelianoff sobre o papel de representação da cooperativa, Torgerson, Reynolds e Gray (1998) compreendem que enquanto representante do agregado de unidades, ela acaba desenvolvendo uma relação de diferenciação de interesses entre os controladores e os seus membros. Os autores então explicam: Emelianoff concluded that cooperatives represent an aggregate of economic units (members) and are not themselves acquisitive economic units. In other words, Emelianoff developed a conception of a cooperative as pure agency with members as principals.(Torgerson, Reynolds, \& Gray, 1998, p. 5).

É por conta desse problema de agência entre os controladores, ou o corpo gestor da cooperativa que se dá a necessidade de uma consideração sociológica a respeito dessas dinâmicas de interação e decisão. É por meio da compreensão do meio no qual se configuram as relações sociais dos agentes que atuam também politicamente que Torgerson afirma:

\footnotetext{
From a sociological perspective at least three purposes of economic organization can be identified: making profits, providing services, and realizing meaning. Their predominance and mix tend to vary both across and within organizations. These differing purposes penetrate the theory and practice of cooperation producing various practical as well as theoretical dilemmas. These dilemmas include (1) meaning versus service, (2) efficiency versus democracy, and (3) bureaucratic logic versus cooperative logic. The intersection of purpose and dilemma tends to fragment understandings of cooperation, negating the economic philosophies of some, while supporting those of others. (Torgerson et al., 1998, p. 8).
}

Esses autores defendem que, com base nas distintas relações entre o modelo que relaciona jogadores e propostas, é que se pode considerar uma diferente configuração desses arranjos a fim de conformar uma interação específica. Assim, consideram a ideia do papel da barganha cooperativa a distribuição dos ativos pelo qual se dá, então, a questão do incentivo à interação econômica entre os participantes deste arranjo cooperativo (Torgerson et al., 1998).

Joseph Staatz (2003) é o primeiro autor que introduz a questão da reflexão do poder em economia no estudo das cooperativas ao tratar da evolução de seus 
desenvolvimentos durante a década de 1980, quando a obra de Emelianoff passa a entrar em um segundo plano, sem ser diretamente citada. Ao demonstrar as diferentes formas como o tema foi tratado, afirma que dentre as interpretações havia basicamente: a ideia de que a cooperativa era uma forma de integração vertical, à qual ele atribui a Emelianoff; a de que a cooperativa era uma firma; e, finalmente, a cooperativa enquanto uma coalizão (Staatz, 1994).

Em um artigo produzido com Michael Cook, Fabio R. Chaddad é o primeiro brasileiro a integrar essa tradição de estudos sobre a cooperação. Diante das transformações do setor agrícola durante a década de 1990 e no começo da de 2000, os autores concebem o surgimento de um tipo distinto de organização cooperativa e se dispõem a tratar a questão por conta de inovações observadas nesse tipo de cooperação (Chaddad \& Cook, 2003).

Propõem cinco modelos de cooperativas não tradicionais, como nomeadas por eles, para observar a relação dos direitos de propriedade e da garantia da propriedade do ativo em meio a uma relação entre investidor e controlador, à medida que esses cinco modelos se referem a formas distintas de captação de recursos e de capital por parte das cooperativas: cooperativas de investimento proporcional; cooperativas de membrosinvestidores; nova geração de cooperativas; cooperativas com entidades de capital seeking; e, por fim, o modelo de investor-share por meio de um fundo de aplicação de capitais (Chaddad \& Cook, 2003).

É por meio da proposição desses cinco modelos que os autores compreendem que, além de conceber a questão da necessidade de meios de controle por parte dos investidores, a questão do incentivo, ou justificação de políticas públicas com a finalidade de fortalecer setores enfraquecidos ou vulneráveis, passaria pela capacidade dessas organizações em captar tais recursos. É tendo isso em vista que eles consideram que, no caso norte-americano estudado por eles:

Clearly, the emergence of non-traditional cooperative models takes the definition of the cooperative as a user owned and controlled organization to the limit. The ownership rights approach to analyzing boundaries of the firm and control - residual claim tradeoffs can also be used to inform public policy debates regarding the degree and role of producers not only as users but also investors in the global food chain. Most analysts agree that the uncertainties associated with globalization, food chain consolidation and vertical coordination, environmental constraints, genetic modification and 
food safety have created an environment in which the public interest must be clearly defined and communicated. A basic public policy issue is to what degree and what role should producers be allowed to participate in this new institutional environment. If the public objective is to facilitate the continuance of the countervailing power and rural development benefits produced by an institutional arrangement that in the past was beneficial to both the American food consumer and the producer then modifications to our current state and national legislation and regulation should be contemplated. (Chaddad \& Cook, 2003, p. 10).

Entretanto, ainda que os estudos tenham evoluído no sentido de compreender novas formas de aporte de capitais e de recursos às organizações cooperativas, o que se pode notar de igual maneira é que não há uma superação das contradições da vida social e do poder. Por isso, a articulação entre a condição econômica de mercado e o poder político evidencia a necessidade da atenção de pesquisadores.

É por meio dessas observações que K. Charles Ling (2012) passa a incorporar esses fatores. O autor opta por não abrir mão de uma teoria econômica autônoma da cooperação e da sua conformação enquanto grupo de poder, tanto na esfera política, mas sobretudo na esfera econômica, além de integrar os elementos de barganha e poder na dinâmica da produção agropecuária (Ling, 2012a).

Para isso, Ling retoma diretamente as concepções de Emelianoff sobre a natureza da organização cooperativa para as atividades agrícolas e sua condição para a compreensão do papel das transações operadas por ela, como forma correcional de mercado, mas que só é possível pela condição do poder de contrapeso na esfera econômica, ou especificamente no lugar de mercado, como proposto por Galbraith (Ling, 2012b).

Contudo, Ling submete a concepção de poder por Galbraith à interpretação de um filósofo da cooperação econômica nos Estados Unidos da América, Edwin Nourse, assim como relaciona o seu pensamento às concepções de Emelianoff quanto à organização cooperativa. Segundo Ling, Nourse considera que a cooperativa enquanto organização tinha uma dupla função: a de fazer o canal de mercado mais eficiente e menos custoso para que os agricultores pudessem ter ganhos de acesso a mercados, além de poder de compra, correspondendo à lógica de preço por oferta e demanda; e a outra, que é refletir essas mesmas condições de mercado intermediando a relação entre ele e os agricultores, ao passo que a cooperativa também os oriente, provendo-os de 
assistência para as mudanças necessárias para sua adequação (Ling, 2012a, 2012b).

\subsection{COMPLEMENTARIEDADE ENTRE CHAYANOV E EMELIANOFF}

Chayanov e Emelianoff têm pontos em comum a respeito da forma como se daria a organização do mercado em um nível macro a respeito do papel das cooperativas no sentido de conformar a estrutura de mercado. Isso se dá pelo fato de que ambos compreendem a ideia de que a abrangência, ou a expansão, das atividades da cooperativa tem como um suposto - e não exatamente com uma concepção clara formada pelos autores - a respeito do que deveria ser a estratégia de atuação da cooperação.

Porém, pode-se dizer que há uma diferença complementar entre ambos quanto à concepção da integração. Ainda que ambos vislumbrem as formas de organização cooperativa como alternativa para a inserção de pequenos produtores no mercado por meio de uma integração vertical, a própria concepção dessa integração de um e de outro é distinta já que, no caso de Chayanov há uma preocupação com a manutenção social através da inovação dos meios de sua reprodução com o ingresso da agricultura moderna. Emelianoff compreende um equilíbrio não entre produção e consumo na unidade familiar, como Chayanov, mas de ingressos e saídas por parte do conjunto de transações realizadas no seio da representação do agregado dessas unidades enquanto uma cooperativa.

Contudo, a diferença que os complementa é a de que Chayanov era um agrônomo que, ao estudar a economia e seus fenômenos acerca de um determinado setor econômico, se especializa em um tema bastante complexo, dado também o seu próprio contato com outro economista, Kondratiev. Nesse sentido, Chayanov é um economista com uma abordagem meticulosa e atenta da agricultura, ao contrário de Kondratiev que trataria de grandes movimentos da economia.

Por outro lado, Emelianoff é, antes de tudo, um estudioso da cooperação econômica e das formas de organização cooperativas em que se consegue de fato um elemento de viabilidade. Na sua busca por formular uma teoria autônoma sobre a cooperação econômica, se nota na verdade que há uma compreensão mais clara de 
gestão e governança da cooperação em organizações, como ele próprio se refere a elas, derivadas. Ele, por isso, considera a ideia de que haja uma autonomia específica por parte dos produtores rurais para que a representação da cooperativa se mantenha na coordenação das suas atividades como uma organização correcional do mercado.

Assim, consideramos que, para os estudos e ações a respeito do cooperativismo em âmbito acadêmico e social, deve-se buscar a reinterpretação desses autores. $\mathrm{O}$ sentido dos novos trabalhos sobre cooperativas deve ser o de esclarecer um debate que, pelas circunstâncias dramáticas das paixões por um novo mundo, não pôde ser feito pelos seus próprios protagonistas, Alexander Chayanov e Ivan Emelianoff. 


\section{O ASSENTAMENTO PIRITUBA}

Para compreendermos o problema da implementação do projeto de um assentamento, como no caso da Fazenda Pirituba, devemos considerar o seu desenvolvimento histórico. Para isso, seria necessário recorrer à produção historiográfica a seu respeito.

Porém, na ausência de uma produção historiográfica sobre a formação do assentamento recorremos então aos recursos existentes no sentido de elaborar, com base nas fontes e interpretações existentes, uma narrativa histórica que possa explicar a sua formação histórica. Não temos aqui a pretensão de produzir um trabalho de história com análise em documentos a respeito da verificação dos fatos históricos, mas, a princípio, um encadeamento das interpretações dentro das fontes disponíveis a seu respeito.

Ao longo dessa de análise do campo, incorpora-se o uso de trabalhos que tratam especificamente a questão em um âmbito local nacional e que tenham relação com o campo. Isso se dá por conta da retomada de observações já feitas ou que são recorrentes nesse meio.

O objetivo deste capítulo é tratar da aplicação das concepções críticas a respeito da economia institucional na análise da perspectiva de poder a respeito das organizações associativas na agricultura. Para compreender essa lógica associativa desde o princípio de sua formação, tomamos aqui o caso do Assentamento Pirituba no interior de São Paulo.

Este assentamento foi palco de diversas experiências associativas de produção e comercialização agrícola, dirigidas ou promovidas por agentes externos à comunidade, seja o MST, seja por intermediação de órgãos públicos. A partir da concepção de poder em economia institucional, demonstra-se aqui, a partir desta pesquisa empírica, que intervenções agrárias de apoio ao associativismo ou ao cooperativismo, quando empreendidas sem organizações de intermediação que equilibrem o ambiente institucional, levam a distorções das estruturas de governança de forma a comprometer tais experiências. 


\subsection{UMA BREVE CONTEXTUALIZAÇÃO DA REFORMA AGRÁRIA NO BRASIL}

O programa de reforma agrária em curso no Brasil tem suas origens no Estatuto da Terra, de 1964 (Lei $\mathrm{n}^{\circ}$ 4.504, de 1964), durante o início do regime militar, sob a aprovação do congresso (Brasil, 1964) e no Plano Nacional de Reforma Agrária (PNRA) via decreto $n^{\circ} 59.456$, de 4 de novembro de 1966. Ao mesmo tempo da edição do Estatuto da Terra, o governo militar criou dois órgãos responsáveis por sua execução, o Instituto Brasileiro de Reforma Agrária (IBRA) e o Instituto Nacional de Desenvolvimento Agrário (INDA).

Porém, apesar da criação desses institutos responsáveis pela observação ao Estatuto e ao PNRA, não houve a sua execução. Com isso, é a partir da fusão desses dois institutos que se dá a criação do Instituto Nacional de Colonização e Reforma Agrária (INCRA) pelo Decreto nº 1.110 , de 9 de julho de 1970.

Entretanto, é somente com a abertura política na década de 1980 que o debate acerca da realização da reforma agrária no Brasil toma um novo ímpeto. Assim, abre-se o espaço para a instituição do Novo Plano Nacional de Reforma Agrária via Decreto ${ }^{\circ}$ 97.766 de 10 de outubro de 1985, seguido da criação do Ministério Extraordinário para o Desenvolvimento e a Reforma Agrária (Mirad).

Contudo, durante os debates na Assembleia Constituinte entre 1987 e 1989, decidiu-se pelo fechamento do INCRA e do MIRAD, colocando a questão sob a responsabilidade do Ministério da Agricultura. A decisão foi rejeitada já em março de 1989 pelo próprio Congresso Nacional, restabelecendo o INCRA e seu papel.

É do acirramento das tensões no campo na década de 1990 que o tema passa a ser ligado diretamente à Presidência da República. Isso se dá pela criação do Ministério Extraordinário de Política Fundiária, posteriormente substituído pelo Ministério do Desenvolvimento Agrário, instituído pelo Decreto n 3.338, de 14 de janeiro de 2000.

Seguindo essa evolução, durante o primeiro mandato da administração Lula que se apresentou o II Plano Nacional de Reforma Agrária, em meio aos debates da Conferência da Terra ocorrida em Brasília no ano de 2003. Nele, alteraram-se as concepções dadas ao PNRA até então. O plano concebe a Reforma Agrária em termos 
de uma política fundiária, mas $\operatorname{sim}$ em termos de "desenvolvimento territorial sustentável", compreendendo por este a viabilidade econômica do empreendimento agrícola, a promoção da segurança alimentar e nutricional, a sustentabilidade ambiental para a garantia ao acesso a direitos civis e à promoção da igualdade, adequando-se a cada bioma local e não mais tomando para si um modelo único aplicável a todo território nacional. Nesse sentido se previa a montagem de um sistema de extensão rural, assistência técnica e pesquisa, crédito, comercialização e agroindustrialização, combinando atividades agrícolas e não agrícolas pelas vias do associativismo e do cooperativismo visando a agregação de valor e a geração de emprego.

\subsubsection{Antecedentes Do Assentamento}

O Assentamento Pirituba II é uma de área 17420 hectares da antiga Fazenda Pirituba localizado às margens do rio Pirituba, entre os municípios de Itapeva e Itaberá no sudoeste paulista, na região entre Itapetininga e divisa com o Estado do Paraná. Os meios de transporte e de comunicação da região com a capital surgiram historicamente por meio da linha ferroviária Sorocabana, a partir do que ficou conhecido como o "Ramal da Fome"10.

Entretanto, em vez da retomada do desenvolvimento econômico, ocorrida em outras partes do estado, a região acabou não se engajando em outras atividades econômicas, mesmo com a industrialização retomada naquele período. Uma das características marcantes da colonização e da exploração econômica da área é que a distância entre os sítios urbanos dos municípios é correspondente ao que seria uma jornada de transporte dos tropeiros pecuários. Nesse ponto, a própria localização do assentamento, em relação à cidade historicamente mais relevante para a sua formação, se aproxima disso, sendo uma distância de 40 quilômetros.

10 A referência ao "ramal da fome" se dava pelo fato de que a partir daquele ramal, o vagãorestaurante disponível era retirado do trem que partia, já que os passageiros com destino àquela área, de maneira geral, não tinham recursos financeiros para consumir as refeições tais quais as oferecidas nesse vagão. 
Figura 11 - Estado de São Paulo com a localização dos municípios

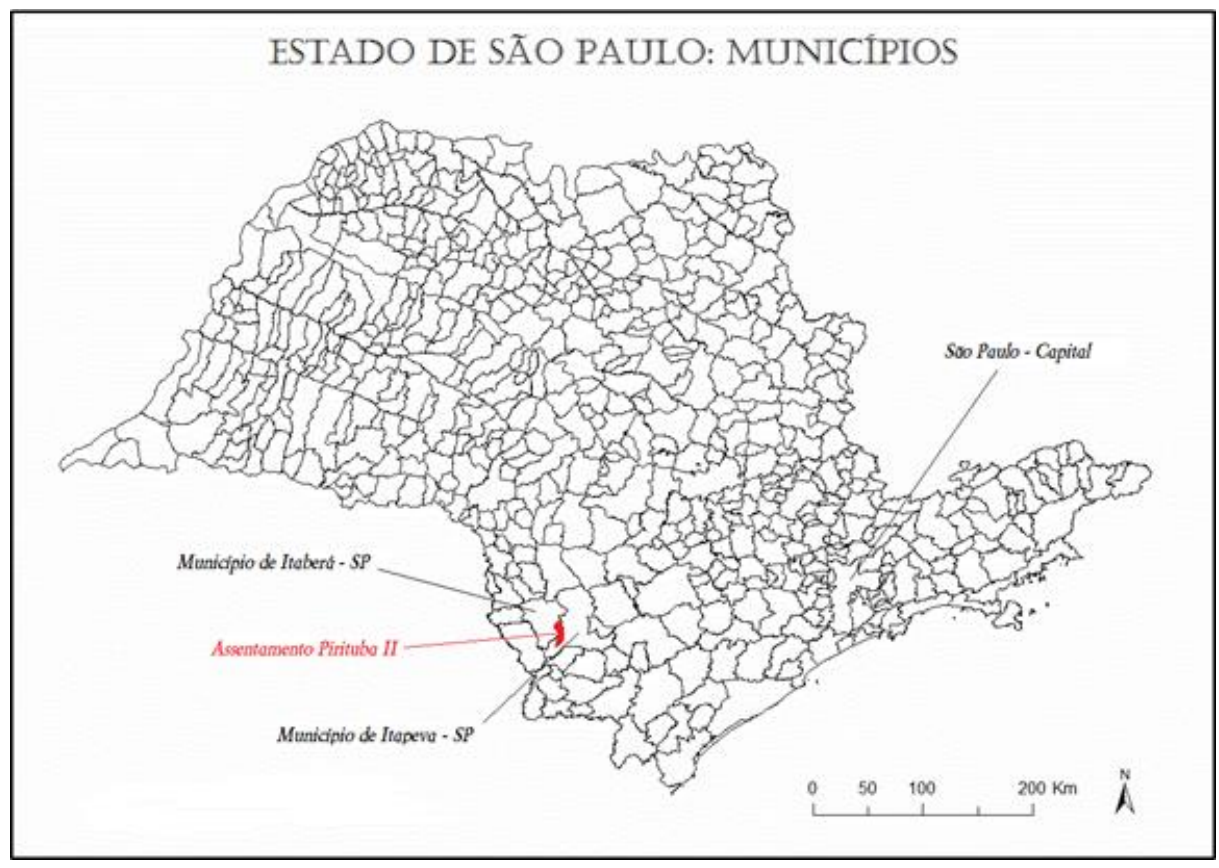

Fonte: Elaborado pelo autor com base em:

http://www.mapasparacolorir.com.br/mapa/estado/sp/estado-sao-paulo-municipios.png

Assim, diante de um período de dificuldades das atividades agrícolas como um todo, no ano de 1949 a Fazenda Pirituba II foi tomada como patrimônio do governo estadual por conta de uma dívida da Companhia Agropecuária Angatuba. Em consequência disso, acabou sendo adquirida pelo governo de Adhemar de Barros em 25 de março de 1950, com a finalidade da implantação de um projeto de produção de alimentos diante do crescimento de um mercado urbano, tendo em vista o aumento da população metropolitana em São Paulo (Andrade \& Pereira, 2000) $\square$.

De uma forma breve, pode-se dividir esses antecedentes em três fases: a da colonização malograda, a da revisão incompleta, e, por fim, a do conflito definitivo.

A primeira foi a do projeto do plantio do trigo, com a colonização italiana, ainda no governo de Adhemar de Barros. A segunda foi a do projeto da Lei de Revisão Agrária por Carvalho Pinto, e a terceira é a do conflito. A implementação do assentamento se deu no governo de André Franco Montoro.

Da mesma maneira, a própria configuração atual do assentamento teve um momento de desenvolvimento posterior ligado à sua expansão. Assim, os diferentes 
momentos da incorporação de novos espaços rurais adjacentes à conquista da primeira atuação se dão também por uma variável temporal que acompanha uma transformação demográfica da composição populacional ali presente (Iokoi, Andrade, Rezende, \& Ribeiro, 2005).

Contudo, deve-se observar que a região do sudoeste paulista acabou por ser, já nesse momento, conhecida como a linha da fome. Esse nome se dá por conta da linha ferroviária que saía de Sorocaba e ligava a região à área metropolitana cruzando, a partir da cidade de Itapetininga, uma área empobrecida à época, em direção à cidade de Itararé.

Uma hipótese levantada nesta pesquisa que pode explicar a causa desse relativo empobrecimento diante de outras regiões do estado, de sua estagnação econômica ou de seu desenvolvimento social, é a da questão da indisposição do governo varguista em relação aos projetos para a região. Isso se daria pelo fato de que Júlio Prestes era baseado em Itapetininga, e esse político paulista era seu imediato rival à presidência 1930. Assim, políticas de melhorias, a partir do governo nacional, de estrutura, como logística e comunicação, poderiam fortalecer Prestes. No entanto, ainda que essa questão em especial mereça atenção por parte dos estudiosos do tema, não há estudos a respeito da relação institucional entre os poderes, união e estados, nesse período que permitam fazer tal inferência ${ }^{11 .}$

Pode-se afirmar que, em termos de apoio ou presença institucional, é possível compreender que há um esvaziamento —ou mesmo um abandono- por parte das autoridades no nível nacional em relação ao desenvolvimento da região. Isso reforçaria a ideia de que é no nível provincial ou estadual que a autoridade pública se faz presente, o que explica as especificidades desse caso, diante de outros sobre a reforma agrária.

Dada essa ausência, somada ao agravamento da situação social no campo, coube ao Governo do Estado de São Paulo a iniciativa para a resolução da questão. Assim,

\footnotetext{
${ }^{11}$ Essa hipótese também se deu diante da apropriação da narrativa de um dos entrevistados que, ao relatar sua interpretação histórica sobre a região, relata a importância da área nesse momento político. Porém, cabe registrar que existem interpretações sobre o fenômeno que tratam de uma pobreza relativa da região de Itaberá, Itapeva e Itararé por sua importância marginal quanto à produção do café no Estado. Contudo, ela se baseia em parte na verificação de relatórios da administração ferroviária sobre o fluxo de outras mercadorias que deveriam ser transportadas pela linha férrea da Estação Engenheiro Maia. A própria Companhia Angatuba tinha um ramal próprio, mas que acabou desativado na década de 1970.
} 
naquela região, as iniciativas de intervenção agrária passam pelo governo estadual, que impõe diferenças de disposição com o plano de reforma agrária a nível nacional.

Durante o primeiro governo de Adhemar de Barros (1947-1951) fez-se um projeto de intervenção agrária reformista incorporando a área da fazenda. Para isso, o governador tinha a ideia de fazer uma colonização italiana para a produção de trigo na região e assim abastecer a Grande São Paulo.

Nesse momento há a chegada do agrônomo italiano Lino Vicenzi* que, em vez de implementar esse plano, acaba por tratar a terra como sua propriedade, desvirtuandose totalmente do propósito social inicial. Não havendo nem colonização, nem produção de trigo, Vicenzi passa a arrendar a terra aos boiadeiros que se apropriam da área a fim de explorá-la economicamente com a bovinocultura extensiva de corte.

Aproveitando-se da quase absoluta ausência de autoridades públicas para a governança dos espaços rurais, os grilos se apropriam da área e se aproveitam da formação de um mercado de terras que se dá durante esse período. Esse seria o primeiro movimento de grilagem que se soma outros desenvolvimentos que restam presentes até o momento do embate final que define a formação do assentamento na sua configuração atual.

Grosso modo, pode-se observar que o processo de grilagem se intensifica nos momentos em que não há uma perspectiva clara de intervenção agrária por parte dos governos. Essa ausência, ou mesmo omissão, das autoridades pode ser considerada um fator para os problemas de governança das terras na região.

Seguiu-se a questão da revolta dos posseiros de 1957 no Oeste do Paraná, que achavam que o projeto de reforma agrária era para eles. Assim, se criou um movimento de reivindicação dos posseiros da área, que precedeu o próprio processo formativo do MST.

\subsubsection{O Governo Carvalho Pinto (1959-Fev/1963)}

Com a chegada ao governo do estado de São Paulo de Carlos Alberto Alves de Carvalho Pinto assistiu-se a uma retomada da iniciativa da proposta de reforma agrária. A composição da equipe desse governo incluía jovens que seriam consagrados 
posteriormente pela sua contribuição ao debate agrário e à política agrária no Brasil, como José Gomes da Silva e Plínio de Arruda Sampaio, este à época ainda de inspiração católica.

Em 1962 o governo tenta retomar o controle da área através de um projeto de colonização. Essa tentativa de intervenção se inspirou na Lei Estadual no 5.994, de 30 de dezembro de 1960, conhecida como "Lei de Revisão Agrária" ou Lei Carvalho Pinto, que previa "promover, mediante loteamento o aproveitamento de terras do Estado que se prestem à exploração agrícola e pecuária" (Brasil, 1960).

Já no ano de 1963 o governo de Carvalho Pinto afasta o agrônomo italiano de sua função revogação a validade dos contratos de parceria e arrendamentos da área mediante o pagamento de indenização. Abre-se então o caminho para que área possa ser objeto da intervenção agrária reformadora.

Porém, diante dos acontecimentos políticos a partir de 1964, houve uma reorientação política por parte do governo que acabou por priorizando outros projetos. Também por conta do fechamento político vivido no período, as próprias mobilizações sociais e seus conflitos viveram um impasse diante da formulação de uma nova política.

\subsubsection{A Década de 1970 e os Governos Militares}

Diante da interrupção do processo de colonização e intervenção na área, o que se nota é que durante os governos militares houve um novo momento de esvaziamento da proposta da ocupação da área, que acabou acompanhada por uma fragilização da política de governança de terras na região. Assim, o espaço que era da antiga fazenda Pirituba foi apropriado por diferentes atores sociais nas suas diferentes áreas.

Diferentemente do que ocorreu durante a década de 1950, quando houve um projeto malfadado de colonização, a década de 1970 já assistia a um processo distinto. Nela havia um fechamento do regime político e se passava por um processo de rearranjo dos órgãos governamentais.

Em 1971 a administração estadual da área passa da Coordenadoria de Assistência Técnica Integral (CATI) para a Assessoria de Revisão Agrária (ARA), agências ligadas à Secretaria de Agricultura. Porém, o objetivo não era a intervenção 
por meio da reforma agrária, mas sim a implementação de um projeto de colonização (Iokoi et al., 2005).

Logo em 1973 é lançado o Programa de colonização Pirituba I. Contudo, também esse plano fracassa, abrindo caminho a um período em que houve um impasse, já que, devido a esses sucessivos fracassos, aprofundou-se o litígio judicial com os boiadeiros que ocupavam área (Costa \& Bergamasco, 2003).

Durante o período de uma longa batalha judicial tentando reaver a área dos boiadeiros, assistiu-se a um processo de grilagem acentuado que envolveu famílias de agricultores da região, além dos próprios boiadeiros e da família Vicenzi, do agrônomo responsável pelo projeto. Num levantamento sobre a atual condição observa-se nesse período:

Em 1975, dos 142 contratos fumados com o Estado, apenas 27 foram regularizados, permaneceram na fazenda os grupos conhecidos como os holandeses, os batagins, os lotistas furlans e alguns remanescentes da família Vincenzi. Esses grupos não atendiam às exigências previstas na lei e o Estado opta pela exclusão dos mesmos através de processos administrativos. Ao mesmo tempo, CPI (Comissão Parlamentar de Inquérito) da Assembleia Legislativa. (Andrade \& Pereira, 2000, p. 84).

É em meio a esse impasse em que as autoridades perdem a iniciativa de intervenção - por conta de diversas dificuldades enfrentadas- que o processo de grilagem se aprofunda. Os casos mais relevantes dos envolvidos em apropriações originadas desse processo nesse período são o da família Batagim -importante na região, descendente de italianos - e os chamados "holandeses" — famílias da colônia holandesa na região fronteiriça entre São Paulo e Paraná, baseados em Itararé, que ocuparam grandes áreas do assentamento e que acabaram envolvidos no conflito já com a segunda geração de assentados, que passaram a reivindicar aquelas áreas tendo em vista a condição ilegal da propriedade daquelas terras (Bombardi, 2005).

\subsubsection{A Abertura Política e o Governo Montoro (1983-1987)}

Durante a abertura política do final do governo militar houve uma turbulência em relação à direção clara das transformações a respeito da representação social e 
política. Isso se expressou já nas eleições diretas para os governadores dos estados da federação.

A campanha de Franco Montoro em São Paulo, à época pelo MDB, foi crucial na conformação de um plano de criação de assentamentos. Porém, nesse sentido, há um plano de Reforma Agrária que vinha em curso a nível nacional, mas que enfrentava resistências e obstáculos por conta da própria indefinição política da transição do governo de transição civil-militar que levaria à conclusão da abertura política.

Em 1983 criou-se uma comissão intermunicipal com representantes da sociedade civil das cidades de Itapeva, Itaberá e Itararé, já na Administração de Franco Montoro (Iokoi et al., 2005). Essa comissão foi criada a partir do agravamento da situação fundiária da região, porém já expressando a necessidade de uma articulação institucional a um nível superior ao municipal, mas que ao mesmo tempo não fosse encarado pelos órgãos com âmbito nacional de responsabilidade agrária. Concomitantemente a essa evolução, em nível estadual, há a criação do Instituto de Assuntos Fundiários (IAF), órgão precursor da fundação do Instituto de Terras do Estado de São Paulo - ITESP (Alves Sobrinho, 2008) $\square$.

Porém, mesmo o logro em eleger um governador estadual ainda não poderia realizar esse projeto, pois, institucionalmente, a responsabilidade pela criação de assentamentos de reforma agrária era federal e não estadual. Assim, para realizar os objetivos de campanha, Montoro decide atuar no sentido de manter o seu projeto, mas a fim de evitar uma já crescente campanha contra si próprio, não encampando a "reforma agrária", mas sim a retomada da precedente Lei de Revisão Agrária.

A princípio, Montoro não tinha um plano claro de como executar a instalação dos assentamentos. As diretrizes da sua intervenção agrária seriam aperfeiçoadas na medida em que a experiência vivida pelos assentados deflagrasse resultados e consequências.

Nesse sentido, em vez de se determinar diretrizes e metas a princípio, as quais os assentados deveriam perseguir a fim de que se mantivesse a política e seu propósito, o que se procurou empreender foi uma atuação capaz de ter uma abertura a demandas e situações das quais não havia previsão. A ideia de que ali se tratava também de uma 
experiência a ser apreciada era importante para se notar que a própria atuação governamental não se expressasse em uma atuação hierárquica diante dos assentados.

Os assentados que permaneceram no assentamento e que vivenciaram todo o processo de instalação, desde as ocupações até a regularização do seu estabelecimento na terra, rememoram a personalidade de Montoro com expressões de gratidão. Atribuise a Montoro, a vontade política de defender a causa dessa população, e com seu nome é batizada a escola estadual localizada na Agrovila 1.

Diante do cenário político da época, a polêmica por conta desse plano de intervenção agrária levada a cabo por Montoro levava a buscas por evidências de sua viabilidade. A esse exemplo:

\footnotetext{
Entrevistada 1: Da terra que ele [Montoro] deu pra nós. Foi ele que deu. Foi ele que assentou a [as áreas] 1 e a 2 . Ele falava que a área 2 era a menina dos olhos dele!

Entrevistada 2: O Mário Covas... o Mário Covas também sempre vinha, né? Entrevistada 1: Vinha. É que a [as áreas] 1 e 2 é o modelo da reforma agrária e ela já tá sendo modelo mesmo.
}

Nesse ponto, pode-se atribuir uma boa relação, ou mesmo a abertura de instituições públicas na cidade, aos assentados das áreas 1 e 2, graças à relação que construíram com Montoro. É importante notar que a relação estabelecida com a área 2 acabou aproximando, e mantendo, os assentados a um determinado setor político do governo.

Assim descreve um dos assentados essa relação com os órgãos públicos desde essa relação:

Entrevistada 1: Eu sou de dentro da prefeitura. A gurizada lá tudo conhece eu e o prefeito, e eu brinco com ele. [inaudível] E eu peço exijo e faço assinar ainda o papel! [risos] Verdade, verdade! E por causa disso que eles [outros assentados] falavam assim: "Ah, você vai entregar a cooperativa pra prefeitura de Itaberá'!", "Ah, você tá indo entregar a cooperativa pro Movimento dos Sem-Terra [MST]!". Meu Deus! Só porque vinham ali conversar com a gente! É... nós sofremos bastante... De cooperativa nós não queremos nem mais saber a gente! 


\subsection{EVOLUÇÃO DO ASSENTAMENTO - DAS ÁREAS 1 E 2 À ÁREA 6}

A princípio, no primeiro espaço concedido, formou-se uma associação para todos os que participaram da ocupação e do acampamento. Contudo, diante das primeiras diferenças, já percebidas entre os assentados, houve a primeira cisão, entre os que defendiam a concentração de casas e os que defendiam casas separadamente em cada lote, o que correspondia a defender entre a organização da produção enquanto coletiva ou individual.

Por conta da própria disposição do governo Montoro em construir o assentamento e demonstrar uma intervenção agrária exemplar, o processo para a formação dessas áreas foi, em comparação com os processos das demais áreas, muito pacífico.

No momento em que se montou o assentamento, o governo estadual proveu os assentados de uma série de recursos que os proporcionasse produzir.

Entretanto, relata-se que em todo esse processo houve uma pressão tanto externa quanto imposta aos assentados, para que fossem tão ou mais produtivos que os grandes produtores. Um registro que expressa o ambiente desse tipo de pressão diante da comparação da produtividade dos assentados com os estabelecimentos agrícolas precedentes à instalação do assentamento pode ser visto em Barretto (2004):

Talvez, o assentamento mais antigo de São Paulo, pois data de 1984. Criado pelo então governador Franco Montoro para fazer - segundo expressão dele "chover dinheiro na região". Mais tarde, Orestes Quércia, em época de eleições, colocou feijão à venda junto às estações de metrô de São Paulo, como sendo o "feijão da Reforma Agrária". A Rede Globo filmou as plantações de feijão dos holandeses que confinavam com o assentamento e colocou no ar como sendo 'plantação de feijão da Reforma Agrária'. Apesar de os produtores terem reclamado do 'lapso' por escrito, ficaram sem resposta, pois o mito da Reforma Agrária não podia ser quebrado. A primeira visita que fizemos à região foi em 1989. Era impressionante o contraste entre a plantação dos holandeses e a dos seus vizinhos assentados. Enquanto a plantação dos holandeses assemelhava-se a um tapete verde, a área contígua parecia terra de ninguém. Hoje, infelizmente, tal contraste não existe mais. Tendo sido invadidas as terras dos holandeses, foi implantado ali um assentamento, que dilacerou o tapete verde e tudo se tornou terra devastada (Barretto, 2004, p. 108). 
Além disso, houve a recusa, por parte dos assentados mais engajados com o MST, em aproveitar a estrutura deixada pelos anteriores ocupantes. Nesse ponto, além da superioridade absoluta em relação à sua produtividade diante dos ocupantes, exigiase, também, que concretizassem um método de produção contraposto ao capitalista dominante e que o superasse enquanto organizador da sociedade.

Em consequência, o que se deu de fato foi o abandono de grande parte do capital imobilizado presente no espaço do assentamento, em forma de estruturas de produção e de seu armazenamento. Além disso, os assentados passaram à produção de alimentos para o consumo do mercado interno.

Deve-se atentar ao fato de que, nos diferentes momentos da formação das áreas, a concessão do tamanho dos lotes é baseada no módulo rural de acordo com cada município, no caso os de Itaberá e Itapeva, que foi diminuindo ao longo do tempo. Assim, aqui se suporia uma diminuição da dotação de terras, o que poderia afetar a configuração de barganha em interações entre os diferentes assentados, pois dependendo da relação de representação destes na organização, pode haver uma distorção que implica na dominância de um ou outro tipo de assentado integrante da cooperação. 
Figura 12 - Mapa do assentamento Pirituba

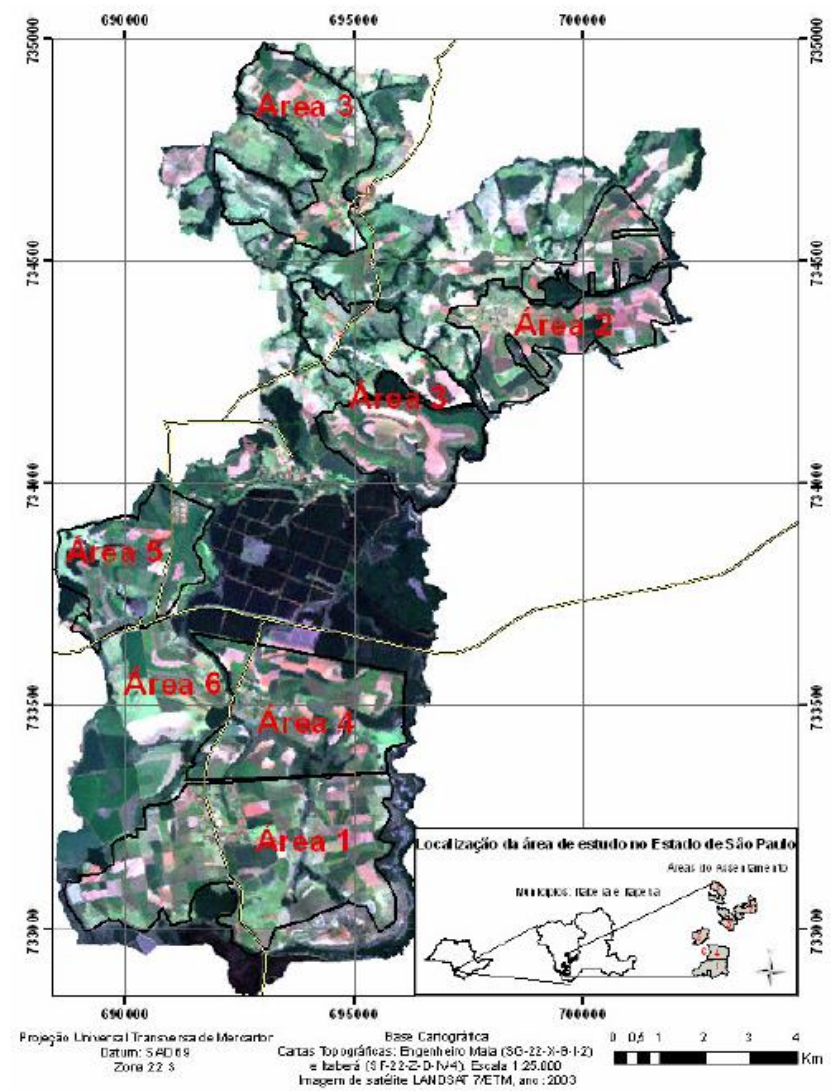

Fonte: Extraído de Shimbo e Jiménez-Rueda (2007).

\subsubsection{As áreas 1 e 2}

Um dos pontos levantados no campo é a ideia de um acampamento comum entre os assentados que posteriormente ocupariam as agrovilas 1 e 2 . Isso é algo que leva a entender que a experiência do acampamento é fundamental para a formação de uma coesão, ou mesmo para a construção de uma interpretação comum da realidade, auxiliando a sua articulação. Como relatado a seguir:

Entrevistador: Pelo que eu entendi as áreas 1 e 2, a agrovila 1 e 2, elas tiveram o acampamento juntos.

Entrevistada

1:

Sim.

Entrevistada 2: Foi diferença de uns dias, né? Lá foi dia 13 de maio. Dia 13 de maio eles assentaram lá. 
Entrevistada 1: E nós dia 22.

Entrevistador: Mas vocês acham que o acampamento foi um... ajudou para ter essa amizade?

Entrevistada 1: Claro, porque nós não conhecia ninguém!

Entrevistada 2: Porque daí só quando saia reunião, ficava todo mundo junto, né? A reunião era... ficava todo mundo junto pra decidir né, a entrada na terra.

As áreas 1 e 2 apresentaram mais coerção para a formação das organizações associativas, devido a uma incompreensão da concepção da intervenção agrária por parte dos agentes governamentais. Assim formou-se a primeira experiência associativa do assentamento, através da organização intitulada Associação dos Pequenos Produtores Rurais da Fazenda Pirituba, em 1985. De acordo com Costa e Bergamasco, em referência ao artigo da ABRA de 1985, Pirituba, Exemplo Vitorioso e Sem Mistérios, o processo de convencimento dos assentados para sua formação se deu por meio de uma longa reunião durante um período de 15 dias, dado o receio da parte dos assentados em integrar uma associação dessa natureza (Costa \& Bergamasco, 2003) $\square$.

Nesse ponto, observam-se no discurso dos assentados, em sua referência aos envolvidos nesse debate, as atribuições dadas para a designação das diferenças percebidas por eles em relação à formação dos grupos, dada a composição da ação coletiva. Com isso, as categorias sob as quais se podem afirmar as clivagens de diferenciação e assimilação no assentamento podem ser infinitas. Entre as observadas, as mais relevantes estão:

- Categorias baseadas em fatores geográficos como: distanciamento entre as agrovilas ou de suas aglomerações habitacionais, e os lados da estrada (1 e 4 são áreas vizinhas entre si de um lado enquanto as áreas 2, 3 e 5 ficam de outro).

- Categorias baseadas em fatores culturais: do estado de origem, e em relação ao nível de urbanização e industrialização da origem dos assentados. 
As ocupações no município de Itapeva ocorreram de 1984 a 1992, e sua regularização variou de 1984 a 1996. Um total de 357 ocupações foram estabelecidas no período, numa área total de 8007,64 hectares, como se vê no Quadro 1.

Quadro 1 - Características dos assentamentos no município de Itapeva

\begin{tabular}{rccccc}
\hline Área & Município & $\begin{array}{c}\mathbf{N}^{\mathbf{0}} \mathbf{d e} \\
\text { Família } \\
\text { s }\end{array}$ & $\begin{array}{c}\text { Início da } \\
\text { Ocupação }\end{array}$ & $\begin{array}{c}\text { Regularização } \\
\text { Estabelecimento }\end{array}$ & $\begin{array}{c}\text { Área Total } \\
\text { (ha) }\end{array}$ \\
\hline $\mathbf{1}$ & Itapeva & 89 & $02 / 1984$ & $13 / 05 / 1984$ & 2511,00 \\
$\mathbf{2}$ & Itaberá & 53 & $02 / 1984$ & $13 / 05 / 1984$ & 1341,20 \\
$\mathbf{3}$ & Itaberá & 73 & $02 / 1986$ & Emergencial até 1996 & 2142,33 \\
$\mathbf{4}$ & Itapeva & 51 & $1 \% 10 / 1989$ & $02 / 1991$ & 1096,83 \\
$\mathbf{5}$ & Itaberá & 39 & $28 / 04 / 1992$ & 1998 & 807,71 \\
$\mathbf{6}$ & Itapeva & 52 & $12 / 1994$ & 1996 & 108,57 \\
Total & & 357 & & & 8007,64 \\
\hline
\end{tabular}

Fonte: Adaptada de Costa \& Bergamasco, 2003; Iokoi et al., 2005; Pilla, Andrade, \& Marques, 2013

\subsubsection{As agrovilas 3, 4, 5, e 6}

A questão da ocupação e do acampamento, além de apresentar maior intensidade do conflito, assemelha-se ao que Hirschman chama em sua teoria de lealdade, tratando dela também enquanto um fenômeno em organizações de iniciação severa. Em outras palavras, a lealdade no seio de uma organização que se articula em torno a um cenário inicial de adversidades ou hostilidades, vividas em comum pelos integrantes desse grupo ou coletividade.

A percepção dessa experiência é tratada aqui. Novamente a questão das diferenças dos processos de ocupação e de recebimento da terra entre as áreas é relatada:

Entrevistada 2: A área mais pacífica e mais... que foi melhor pra você entrar foi aqui, foi a um e a dois. Que o fazendeiro não reivindicou ele não fez briga, ele não fez nada, ele só falou... como que era o nome dele?

Entrevistada 1: Aquele era o Omar Tupã. 
Entrevistada 2: Ele só falou assim 'gente', falou pros organizadores 'só quero que tire pra os palanque, os arame e deixe... a sede era na antiga casa ali, né? deixe lá que um dia eu mando buscar.' Ficou cinco anos ali e nunca ninguém buscou. Aí o pessoal dividiu. Ele nunca voltou. Ele nunca brigou. Ele nunca fez nada. Agora a área 3 foi terrível. A área 3 jogaram até merda de porco no povo com avião. Judiaram muito com o pessoal da área 3.

Entrevistada 1: A [área] 3 foi quase oito anos pra eles assentar

No caso, o que se observa é que as agrovilas 3, 4, 5 e 6 passaram uma experiência de formação através de um conflito mais radical que as primeiras. Isso tem como consequência uma diferença em relação ao que se observa enquanto fatores proporcionadores de uma articulação para a ação coletiva.

Nesse ponto, um maior tempo de experiência do acampamento na ocupação não apenas levou os grupos a apoiarem, ou tenderem a apoiar, as experiências coletivistas de produção, como também conforma grupos de interesse mais coesos na disputa com assentados de outras agrovilas que não passaram por igual experiência. Porém, além da ocupação, deve-se notar que essa experiência pode não se encerrar apenas com o fim do acampamento, podendo se prolongar enquanto houver insegurança dominial no seu processo de conquista da terra, até a resolução judicial de seu domínio da terra.

É em meio aos momentos das áreas 3 e 4 que há a entrada dos holandeses em Pirituba e que se inicia o conflito com os sem-terra, solidarizados pelos recémassentados de outras áreas. Esse conflito com os holandeses se estendeu também à área 5 , ainda que em menor grau do que o das duas anteriores, também porque o domínio desses últimos era menor em área relativa diante da 3 e da 4.

$\mathrm{Na}$ área 3, a formação do assentamento se dá a partir do acampamento Olívio Albani, nome de um trabalhador rural morto pela brigada militar em Palma Sola, no estado de Santa Catarina, e homenageado pelos sem-terra à época. Ali se deu o princípio de um longo enfrentamento com "os Batagins" que detinham a área. Tratou-se de um primeiro embate entre a necessidade de ação coletiva do movimento social, porém em um contexto distinto do passado com Montoro, pois a disposição do governo em atuar em favor dos movimentos pela terra havia diminuído.

Especificamente na área 3, a formação da agrovila configurou-se a partir da dinâmica que se relaciona com os conflitos sobre a ação coletiva. São três aglomerações habitacionais, em áreas distintas: a principal, onde fica a Cooperativa de Produção 
Agropecuária Vó Aparecida (Copava) de produção coletiva; a segunda maior, a "rua de baixo", onde houve uma dissidência inicial e, por fim, a área da Água Azul, mais afastada do núcleo formado pelas duas primeiras, formado a partir de um grupo de moradores que decidiu se separar dos demais.

Já a área 4 é onde se dá o conflito com os holandeses de forma aberta e direta. A contradição dos interesses entre os envolvidos e o desafio dominial dos movimentos pela terra aos ocupantes holandeses passou a compor um cenário cada vez mais violento.

Contudo, a área 5 era de patrimônio público quando do momento de sua ocupação, com apenas alguns lotes sob domínio dos holandeses. Então, apesar do conflito existente já entre os sem-terra e os holandeses, este acabou sendo bastante aliviado por conta de uma decisão judicial que acabou, por fim, definindo os direitos dominiais do espaço da agrovila.

Por fim, a área 6 foi durante o seu período inicial uma área emergencial, onde já se previa o seu assentamento. Assim, a incorporação das áreas para a sua implementação é em um momento em que os trâmites de sua regularização já não implicavam mais em tomadas de espaço ou áreas nas quais houvesse esse tipo de litígio, sendo um momento de relativo apaziguamento.

Cabe lembrar que a expansão do assentamento não finda na fundação da área 6 . O que se passou a partir de então, a exemplo do que aconteceu com a área 6 , é que os espaços de expansão do assentamento deixam de ter continuidade ou mesmo de constituir centro. Acabam dispersos e, por fim, encampam famílias que ocupam suas imediações, sendo referidos pelos próprios assentados como constituintes da área 6 .

\subsection{A TRAJETÓRIA DO MST}

As tentativas de interpretação da formação histórica do Movimento dos Trabalhadores Sem-Terra (MST) são de diferentes naturezas e pressupostos teóricos no exame dos fatos sociais contidos nessa formação. A relação desta com as interpretações vigentes conflagram diferenças cruciais a respeito do que se pode atribuir à formação do movimento. 
Sua relevância, além de atrair intérpretes de diferentes áreas do conhecimento, com seus diversos problemas, acaba por também incluir a questão da internacionalização dos estudos sobre o MST. Cabe aqui observar uma produção estrangeira sobre o movimento que o relaciona com diversos outros movimentos de natureza parecida, seja quanto à questão da terra, seja quanto às questões das inovações quanto à produção, como no caso em voga, a agroecologia.

Dezessete trabalhos considerados por esta pesquisa como os mais relevantes na abordagem da questão do MST são apresentados a seguir, de acordo com nome do autor, título da obra e seu objetivo.

1. Merve Çelikten (2014), em Land Struggle and Beyond: Landless Rural Workers' Movement of Brazil, apresenta uma aproximação teórica da perspectiva do domínio da terra e de sua condição anticolonialista de José Mariátegui e a interpretação da luta contra-hegemônica de Antônio Gramsci, compreendendo o movimento em um âmbito global, como um novo tipo de movimento social $\square$;

2. Anthony Pahnke, Rebecca Tarlau \& Wendy Wolford (2015), em Understanding Rural Resistance: Contemporary Mobilization in the Brazilian Countryside, reúnem trabalhos sobre as diversas experiências de mobilização e da luta social no campo, buscando compreender a mobilização da organização do MST com as proposições que desafiam o capitalismo no âmbito produtivo, através da agroecologia, das relações com movimentos indígenas e quilombolas, das interações com os agentes públicos e com a Confederação Nacional dos Trabalhadores Rurais e Agricultores Familiares (Contag), além de sua relação com o movimento contra o projeto de Belo Monte;

3. Sarah Anton (2011), em From Food Security to Food Sovereignty: The Fome Zero Food Acquisition Program in the Pontal do Paranapanema, Brazil, trata do lançamento do Programa de Aquisição de Alimentos (PAA) e da concepção de luta social em torno ao conceito de "soberania alimentar" defendido pelo movimento $\square$; 
4. Carlos Pestana Barros, Ari Francisco de Araújo Júnior e João Ricardo Faria, (2013), em Brazilian Land Tenure and Conflicts: the Landless Peasants' Movement, examinam, a partir de um estudo quantitativo, as variáveis da relação entre a ocupação de terra por meios violentos e sua relação com meios institucionais, cobertura da mídia, valor de mercado da terra e do preço de sua expropriação, assim eles propõe um modelo teórico composto por nove fatores que determinam a ocupação de terras: o Partido dos Trabalhadores (PT), o Instituto Nacional de Colonização e Reforma Agrária (Incra), o Programa Nacional de Fortalecimento da Agricultura Familiar (Pronaf) a pobreza, a produtividade agrícola, a densidade populacional, os conflitos sobre a água, as manifestações e ações de resistência e, por fim, as tentativas de assassinato e as ameaças de morte $\square$;

5. David Meek (2011), em Propaganda, Collective Participation and the 'War of Position' in the Brazilian Landless Workers' Movement, faz um estudo sobre os textos dos jornais publicados pelo movimento ao longo de 25 anos, nos quais analisa o papel da formação política e da propaganda em seu sentido pedagógico, no esforço empreendido pelo movimento a fim de promover a participação cooperativa no movimento e o seu sentido de luta contrahegemônica. A partir da teoria de Gramsci, usando o conceito de organização da cultura e das instituições públicas, defende que a cooperação e o cooperativismo no MST são compreendidos como instrumentos de luta pela elevação da consciência revolucionária dos mesmos através da implantação das cooperativas $\square$;

6. David Meek (2014), novamente, em Movements in Education: The Political Ecology of Education in the Brazilian Landless Workers' Movement, tese de doutorado em que aprofunda a discussão ao tratar dos movimentos de educação, não apenas a partir do material de propaganda, na disputa empreendida pelo movimento, em uma análise de economia moral e da formação da territorialidade a partir da defesa da agroecologia pelo movimento em sua atuação no Sul do Pará $\square$; 
7. Monique McKenna (2004), em The MST and the Myth of the Brazilian Land Reform, onde aborda reforma agrária como um mito que não se realizou e que dificilmente se realizaria, uma vez que o problema da terra no Brasil é parte de um problema maior, referente a um dilema fiscal, pois a própria intervenção agrária alteraria o mercado de terras e sua governança;

8. Wilder Robles (2001), em The Landless Rural Workers' Movement in Brazil, trata da gestação de uma nova concepção de cooperativas baseadas na integração de uma nova forma de produzir, a partir da formação de escolas que gerassem conhecimento e tecnologia apropriada à escala dos produtores assentados, ainda sob a perspectiva de uma integração vertical e da relação do mercado doméstico com o conceito de "segurança alimentar" à época $\square$;

9. Dawn M. Plummer (2008), em Leadership Development and Formação in Brazil's Landless Workers Movement (MST), expõe a concepção da formação de lideranças por parte do MST, seu desenvolvimento e sua institucionalização, apresentando uma periodização a respeito de suas diferenças em três períodos, de 1986 a 1990, de 1990 a 2000 e de 200 até o presente $\square$;

10. Laura Landertinger (2009), em Brazil's Landless Workers' Movement (MST), argumenta que o sucesso do movimento se deve à sua capacidade de não se ordenar ou regrar, criando então espaço para a captura de oportunidades políticas abertas pelas diferentes situações, o que leva ao um sucesso tático, como no caso da iniciativa autônoma e local em suas decisões a respeito de fazer ocupações de terras $\square$;

11. Markus Kröger (2010), em The Politics of Pulp Investment and the Brazilian Landless Movement (MST), discute a relação conflituosa entre os investimentos em celulose e o MST no âmbito da sua contradição institucional, no qual se configuraria uma aliança entre o governo e a indústria $\square$;

12. Genny Petschulat (2010), em Grass-Roots Struggle in the Culture of Silence: Collective Dialogue and the Brazilian Landless Movement, apresenta, a partir 
das concepções de Paulo Freire, a concepção do emudecer e do silêncio da população rural e a ideia da construção do diálogo coletivo por parte do movimento como forma de superação dessa condição;

13. Gabriel Ondetti (2008), em Land, Protest, and Politics: The Landless Movement and the Struggle for Agrarian Reform in Brazil, que, de fato, propõe uma periodização do movimento baseada numa teoria que envolve um diálogo crítico com a clássica teoria da ação coletiva de Olson, e de outros autores de teoria social, abordando o desenvolvimento dos fatos observados na evolução de sua narrativa;

14. Rebecca Tarlau (2015), em Not-So-Public Contention: Movement Strategies, Regimes, and the Transformation of Public Institutions in Brazil, utiliza o conceito de Charles Tilly de "espaço do regime" para examinar as estratégias utilizadas pelos ativistas do MST em sua guerra de posição. Em termos gramscianos, trata de um projeto educacional local e conclui que os avanços alcançados pelo movimento são contraditórios $\square$;

15. Bruce Gilbert (2006), em Workers' Power and Socialism: A Study of Brazil's Movement of Landless Workers, defende que o MST é um modelo por meio do qual se consegue, através da mobilização social, a vitória sobre o capital, desafiando as interpretações do pós-Guerra Fria de que o socialismo havia tomado uma derrota definitiva;

16. Angus Lindsay Wright \& Wendy Wolford (2003), em To Inherit the Earth: The Landless Movement and the Struggle for a New Brazil, reúnem histórias de diversos personagens e a relação destas com a trajetória e o projeto do MST;

17. Wendy Muse Sinek (2007), em Coalitional Choices and Strategic Challenges: The Landless Movement in Brazil, 1970-2005, trata do processo de formação do MST que passa por uma coalização com diversos setores da sociedade —como setores da Igreja como a Pastoral da Terra- em uma aliança que é 
progressivamente substituída na medida em que o movimento passa a se tornar autônomo e se articula em um nível internacional.

\subsubsection{Formação (1979-1984)}

Diante do agravamento da situação social no campo conflagrou-se um aumento da população desocupada nos campos sem possibilidades migrar para as cidades no final dos anos 1970 e princípios dos anos 1980. Muito disso se deu por conta de transformações observadas no campo brasileiro visando à promoção do uso de inovações.

Os quadros administrativos do setor passaram também a exigir menos mão-deobra, não apenas no seu aspecto produtivo. Isso acarretou um desequilíbrio social em que, em busca de oportunidades de se reinserir socioeconomicamente, amplos estratos sociais se depararam também com um problema de governança de terras, que poderia atenuar ou mesmo reequilibrar esse cenário social em vias de um novo arranjo social em decorrência dessa transformação do campo brasileiro (Navarro, 2015) $\square$.

Dada essa transformação, a mobilização dessa população passa a ser capitaneada por diversas lutas locais, por essa população que é marginalizada. Assim é que se dão as condições sociais necessárias para a formação do MST.

No caso do processo de formação do assentamento Pirituba II, deve-se citar aqui a existência de outras organizações. Relata-se também a existência da Frente Nacional do Trabalho, que já atuava antes do MST com a população da região que havia sido afastada da terra, contando com o apoio de setores da Igreja, como a Comissão Pastoral da Terra.

\subsubsection{Crescimento (1984-1992)}

Dada a crise econômica da década de 1980 —"a década perdida"—, o esvaziamento do campo e o agravamento das mobilizações sindicais, levando ao empobrecimento geral da população, as lutas no campo ganham repercussão. Apesar de os movimentos serem locais, o MST passou ganhar proeminência e a se articular como um movimento de direção sobre as mobilizações locais (Fernandes, 1999) $\square$. 
Aproveitando-se do momento da abertura política e da mobilização de outros setores sociais em torno à campanha das diretas, o MST passou também a ganhar seus primeiros arranjos organizativos com capacidade operacional, além de se afastar dos quadros da Igreja Católica. Nesse momento, o movimento passa a elaborar os primeiros modelos para as posteriores experiências de organização produtiva de assentados.

A primeira conquista da luta pela terra em nível nacional da qual o MST fez parte foi a da aprovação do primeiro Plano Nacional de Reforma Agrária (PNRA), em maio de 1985, no início do governo Sarney. Nesse momento, o MST fazia parte de uma frente única com diversos setores sociais, como os tradicionais setores sindicais representados pela CONTAG, ONGs de variados propósitos, assim como órgãos da Igreja Católica e de outros movimentos de luta social (Moraes \& Coletti, 2006) $\square$.

Em meio ao contexto de incerteza e abertura institucional do período da Constituinte, o exercício da mobilização social ganha notabilidade diante da conformação da legislação fundiária, configurando o arcabouço institucional de amparo legal à reforma agrária. Outro acontecimento importante desse período foi a mobilização da campanha pelo impeachment de Fernando Collor, em que, novamente, houve a oportunidade de angariar apoio popular à agenda social.

\subsubsection{Auge (1992-2003)}

A década de 1990 foi a que assistiu, até então, o auge do movimento. As reformas liberais, ou neoliberais ${ }^{12}$, promovidas inicialmente pelo governo Collor (19901992) e aprofundadas durante o governo de Fernando Henrique Cardoso (1995-2002), foram o momento-chave para a afirmação do movimento em todo o território nacional.

No entanto, os acontecimentos que influenciaram diretamente a atuação do movimento e de sua figura como defensor de uma causa agrária foram especificamente dois: os massacres de Corumbiara no Maranhão, em 1995, e do Eldorado dos Carajás no Pará, em 1996, que deflagraram grande comoção, sendo o momento em que o alcance

\footnotetext{
${ }^{12}$ Há um extenso debate sobre o uso devido de um ou de outro termo. Prefere-se aqui evitar esse debate terminológico por ser infrutífero. De qualquer maneira, compreende-se aqui que se tratou de uma renúncia da iniciativa governamental, na sua representação do Estado, nas atividades econômicas e na provisão de serviços básicos e diversos.
} 
das mobilizações pelo movimento se expandiram, conformando-se numa ação política

direta e de massas. Bernardo Mançano Fernandes (1999) expõe esses acontecimentos:

Durante cinco meses, de 5 de novembro de 1995 até 8 de março de 1996, em torno de mil e quatrocentas famílias montaram acampamento no Centro de Orientação e Formação Agropastoril de Curionópolis, aguardando o resultado da vistoria da Macaxeira. No laudo de avaliação "técnica”, o latifúndio foi classificado como produtivo. Os sem-terra ocuparam a Macaxeira e organizaram a resistência contra os jagunços e a Polícia. Iniciaram o processo de negociação com o Incra que propôs assentá-los em um projeto de assentamento de cento e cinqüenta mil hectares, na região de Tucuruí. Os sem-terra não concordaram. Muitas famílias haviam enfrentado problemas com malária naquela região. Não aceitaram o desterro, o objetivo das famílias era o latifúndio Macaxeira. Há tempos, a Macaxeira havia sido dividida em treze fazendas (Essa é uma estratégia muito utilizada pelos latifundiários para evitarem a desapropriação), de modo que os sem-terra iniciaram as pressões para tentarem mudar a conjuntura. No dia 10 de abril de 1996, em torno de duas mil pessoas iniciaram nova marcha para Belém. No dia 16 de abril de 1996, quando chegaram na "curva do S", em Eldorado dos Carajás, os sem-terra decidiram bloquear a rodovia PA 150, como forma de pressionar o governo para a negociação e exigir comida. Com o bloqueio, o governador enviou um comandante da Polícia Militar de Parauapebas para negociar. Ficou acordado que se a rodovia fosse liberada, o governo enviaria alimentos e 50 ônibus para que os sem-terra fossem até Marabá, onde haveria negociações com o superintendente do Incra. Às onze horas do dia 17 de abril, foram informados pelo comandante que o acordo não seria cumprido. Os sem-terra decidem bloquear a rodovia novamente. Às 16 horas chegaram dois batalhões da Polícia Militar: um vindo de Marabá e o outro de Parauapebas. E não vieram para negociar. Chegaram atirando e jogando bombas de gás lacrimogêneo. Os sem-terra tentaram reagir com pedras e paus e com as poucas armas que tinham. Aconteceu o massacre. Segundo os dados oficiais: foram dezenove sem-terra mortos. A repercussão desse fato foi internacional. Era o segundo massacre no governo Fernando Henrique Cardoso. O primeiro foi em Corumbiara, Rondônia, em 9 de agosto de 1995, quando quinhentas e quatorze famílias, organizadas pelo Sindicato dos Trabalhadores Rurais de Corumbiara, ocuparam a fazenda Santa Elina. Durante o despejo violento, dez sem-terra e dois policiais foram mortos.

No dia 2 de maio de 1996, doze membros da Coordenação Nacional do MST reuniram-se com o presidente Fernando Henrique Cardoso e com o ministro da reforma Agrária, Raul Jungmann. Por causa do massacre, o presidente havia criado o Ministério Extraordinário de Política Fundiária, em 30 de abril de 1996, e demitido o ministro da Agricultura José Eduardo Andrade Vieira, sob cujo comando estava o Instituto Nacional de Colonização e Reforma Agrária. O MST apresentou ao presidente alguns pontos fundamentais para a realização da reforma agrária, responsabilizou o governador Almir Gabriel e o ministro da Justiça pelo Massacre de Eldorado dos Carajás, exigiu a prisão preventiva dos policiais que participaram do episódio e reivindicou a desapropriação imediata do latifúndio Macaxeiras. (Fernandes, 1999, p. 197198).

Ocorre, então, a chamada "Marcha para Brasília", em abril de 1997, considerada o acontecimento político mais importante da história do movimento, 
em que integrantes do movimento de todo o país foram à capital federal propor suas reivindicações. Diante da força demonstrada pelo movimento, as lideranças do MST acabam recebidas no gabinete da Presidência da República. Esse foi o ponto máximo da atuação do movimento e, a partir desse momento, este passou a ter de enfrentar o dilema entre capitular da inspiração contestatória e de uma agenda anticapitalista, aceitando a proposição de reforma agrária de então, ou manter as aspirações de combate contrassistêmico, porém sem ter esse acesso ao poder. Optou-se pela segunda opção (Moraes \& Coletti, 2006) $\square$.

\subsubsection{Reestruturação (2003- Hoje)}

Em meio a um ambiente de aprofundamento da situação social e de sucessivas crises econômicas que atingiram também a economia brasileira, a campanha presidencial de 2001 se tornou um fato político brasileiro de importância histórica. A eleição de Luís Inácio Lula da Silva à presidência foi encampada pelo movimento como uma esperança de superar o impasse de seu destino político gerado após as negociações desde a Marcha para Brasília (Moraes \& Coletti, 2006).

Porém, ao contrário do que se poderia supor, a reforma agrária não teve uma larga expansão durante o governo Lula (2003-2010). Na verdade, o que aconteceu foi uma série de mudanças na perspectiva institucional no sentido de auxiliar o pequeno produtor com acesso a crédito e formação de mercados institucionais e de integração comercial que, não necessariamente, corresponderiam à agenda inicial do próprio movimento. O número de ocupações promovidas também diminuiu nesse período.

Em relação ao governo Dilma (2011-2016), quando se deu o início dos desenvolvimentos da crise econômica atual, pode-se considerar que as manifestações do movimento passam a ganhar radicalização, por conta do próprio ambiente político.

Porém, ao longo de todo o período do governo do PT, apesar de tanto o número de assentamentos como o de ocupações haver diminuído, o acompanhamento dos documentos, diários, informativos e notas emitidas pelo movimento, assim como os resultados de seus congressos mais recentes, indica essa radicalização propositiva. 


\title{
5.4 A HISTÓRIA DO ITESP
}

O Instituto de Terras do Estado de São Paulo, o ITESP, é o atual responsável pela manutenção de diversos assentamentos desse estado, incluindo o assentamento Pirituba, em Itapeva e Itaberá. Porém, enquanto órgão do governo, em sua configuração atual, é posterior à fundação do próprio assentamento.

A origem do ITESP está ligada à Lei de Revisão Agrária, ou Lei Carvalho Pinto, a partir da iniciativa do governo estadual. Um dos órgãos de sua origem é Assessoria de Revisão Agrária (ARA) que previa a execução dessa revisão baseada em suas prerrogativas estabelecidas em 1962. Alves Sobrinho (2008) explica:

\begin{abstract}
A demanda pela Reforma Agrária, grande motivadora da luta dos trabalhadores rurais, foi levada para o "grupo de agricultura Madre Teodora", responsável pela formulação nessa área da proposta do Governo Montoro. A articulação e motivação de atuação dessa demanda (reforma agrária) foi levada para dentro do governo pela Comissão Agrária do PMDB-SP com a participação ativa de trabalhadores rurais e técnicos comprometidos com a questão agrária. Entre esses técnicos destaca-se José Gomes da Silva, membro-fundador da ABRA- Associação Brasileira de Reforma Agrária, o qual assume a pasta da Secretaria da Agricultura do governo Montoro, tendo convidado outro técnico, Jose Eli da Veiga, a integrar sua equipe na Secretaria (p. 7) $\square$.
\end{abstract}

A ARA passa a ser denominada Assessoria Técnica de Revisão Agrária (ATRA) a partir de 1978, e o uso do termo "técnico" parece expor uma tentativa de mitigação da contradição política prevista sobre o tema. Chamado para atuar no governo de Montoro, José Eli da Veiga organiza o Instituto de Assuntos Fundiários (IAF), à época da formação do assentamento, proveniente do corpo burocrático da própria ATRA. Alves Sobrinho (2008) comenta:

Começamos, portanto a nossa história com a formação do IAF- Instituto de Assuntos Fundiários em maio de 1983, vinculado à Coordenadoria Socioeconômica da Secretaria de Agricultura e Abastecimento. A sua estrutura era precária, o corpo técnico era contratado por diversos órgãos da Administração do Estado (CEAGESP, CEPAM, Etc.), em sua maioria jovens recém-formados com uma grande disposição pessoal de levar adiante, sob todas as dificuldades, essa nova empreitada na área da reforma agrária. $\mathrm{Na}$ sua concepção e formação trazia a experiência acumulada e uma avaliação crítica dos projetos de colonização realizados pela lei de Revisão Agrária, promovidos pela ARA- Assessoria de Revisão Agrária e posteriormente pela 
ATRA- Assessoria Técnica de Revisão Agrária todas pertencentes à Secretaria da Agricultura. Herdou, inclusive, vários processos administrativos que ainda se encontravam sem solução para estes projetos de colonização a exemplo: da Fazenda Pirituba e Jacilândia, necessitando de providências e conclusão. (Alves Sobrinho, 2008, p. 24).

Durante o processo do assentamento foi feito o Plano de Aproveitamento da Fazenda Pirituba, que previa uma forma de melhorar o nível de renda dos assentados tendo em vista sua capacidade produtiva, que se via subaproveitada para esse fim. A ideia de "aproveitamento" se deu a partir da concepção de que a ali se tratava de fato de uma "revisão agrária", ou seja, de uma reorganização dos ativos disponíveis para aumentar a produtividade das unidades produtivas e, consequentemente, elevar o nível de vida dos assentados.

Por pressão política, a organização representante dos interesses locais dos assentados, por pressão política passa a ser incorporada pela burocracia do governo estadual, (Alves Sobrinho, 2008), e a participação do MST nesse processo é reconhecida pelo próprio órgão em uma publicação recente sobre a sua formação:

Durante a campanha, líderes do MST reivindicaram do candidato Fleury compromissos com a questão agrária, especialmente quanto à criação de um órgão de terras estadual que aglutinasse o Departamento de Assentamento Fundiário (DAF) e o Departamento de Regularização Fundiária (DRF). Fleury prometeu criar o órgão, em troca de apoio eleitoral, e cumpriu a palavra. Com a sua vitória, houve articulações políticas em torno de cargos e composição de equipes. No caso do DAF e do DRF, as discussões se deram no âmbito da Coordenadoria do Programa de Regularização Fundiária da Procuradoria Geral do Estado (PGE), para definição das políticas e da estrutura administrativa do novo órgão, cuja criação se tinha como certa . (Pilla et al., 2013, p. 64).

A importância atribuída à questão agrária, de regularização e promoção social da população do campo, ganhava peso. A versão sobre a motivação naquele momento, expressada por um dos militantes do movimento à época que participou desse processo, é descrita a seguir:

Entrevistado 1: Você sabe que o ITESP só existe hoje, porque nós peitamos [o governo] pro ITESP existir. Quando nós ocupamos o DAF [Departamento de Assuntos Fundiários], hoje o prédio do ITESP lá da Brigadeiro Luís Antônio, né? E isso, o Mauro, nem o Celso e nenhum deles fala, né? Porque eles estavam tudo desempregado e nós falamos "não, nós vamos, nós queremos que os caras são da assistência técnica nossa e ... Bom, tem uns que a gente se arrepende até o último fio de cabelo né? Que nós defendemos aí. 
Mas foi pra garantir que o Instituto de Terra, né? Para que o Departamento de Assuntos Fundiários, na época, continuasse existindo. Porque era a garantia que teria novos assentamentos. Porque se não existisse, não saía assentamento novo. Então, uma das coisas que garantiu aí... um pouco essa parceria nossa, com todos os problemas que a gente tem e briga de vez em quando com os caras, mas fala mal mesmo. Mas é que se não existisse o MST e não existisse assentamentos do estado [do Governo do Estado de São Paulo] hoje o ITESP não existiria. Tanto que agora, nessa [reunião, a primeira coisa que foi falado pro governo é que a gente não quer que feche o Instituto de Terras, já que eles tão tentando fechar tudo que é instituto aí. Essa é que é a questão da garantia de que o assentamento tenha um... ande. Então hoje aqui nós tamo junto né? ${ }^{13}$

A percepção de que os técnicos que formariam o ITESP eram parte do movimento, implica compreender que, com a sua incorporação no governo, eles teriam, ou esperariam ter ali seus representantes. Porém, como se pode observar, a articulação do Instituto acaba também ampliando outras demandas que já existiam como órgãos de atuação do governo do Estado e que acabam por também influenciar a representação que essas organizações em conjunto teriam por meio do exercício institucional do órgão:

\begin{abstract}
Assim em março de 1991 no governo Fleury, é criado o ITESP - Instituto de Terras do Estado de São Paulo com a incorporação e unificação do DAF Departamento de Assentamento Fundiário, que sai da Secretaria da Agricultura e Abastecimento, levando pessoal e experiência acumulada em relação às atividades de assentamentos, e do DRF-Departamento de Regularização Fundiária, sob a forma de Coordenadoria, passando a ser vinculado à Secretaria de Justiça e Defesa da Cidadania, também recémcriada sob a égide da cidadania, com a atribuição de executar a política agrária e fundiária no Estado. Das experiências anteriores decorrentes do artigo 13 da Lei 4957/85 (assentamentos provisórios) se inova e se materializa o CSCF- Centro de Soluções de Conflitos Fundiários para as atividades de mediação entre os trabalhadores e Estado e o CCTA - Centro de Capacitação Técnica Agrária para capacitação dos trabalhadores assentados e do corpo técnico decorrente das experiências educativas do IAF. Amplia-se, ainda, a atuação para o atendimento dos quilombolas criando-se, no âmbito do ITESP, a Assessoria Especial de Quilombos (Alves Sobrinho, 2008, p. 26).
\end{abstract}

A participação de movimentos sociais nesse processo foi fundamental para que isso pudesse acontecer, na medida em que se constituíam como a fonte de poder na barganha entre o executivo do poder público diante de interesses de outra natureza.

\footnotetext{
${ }^{13}$ Mauro e Celso são nomes fictícios referindo-se aos envolvidos na questão da relação entre o assentamento e a formação do ITESP.
} 
Porém, apesar dessa relação, nota-se pelo discurso acima, que ela não era clara, ou assim posta. O objetivo da expansão das áreas por reforma agrária, por parte do movimento - e não necessariamente a atividade processual de fortalecimento do ITESP enquanto uma entidade representativa da coletividade dos assentados - se soma à ideia de que, pelo discurso, o militante do movimento não tem clara condição.

A aceitação do ITESP por parte dos assentados se dá por diferentes razões: desde a cumplicidade criada pelas relações interpessoais dos próprios funcionários diante das dificuldades do processo de ocupação da área e da sobrevivência em um ambiente hostil que cria os laços de confiança, até porque, ao representá-los, ou agir em função da resolução das necessidades dos assentados, os agentes públicos não se diferenciavam deles enquanto alvos das pressões e hostilidades por eles sofridas.

Um relato expõe a mesma experiência em um acampamento de ocupação em que um funcionário do estado, por conta da própria precariedade da condição de trabalho à qual estava sujeito fez com que ele compartilhasse essa situação, superando uma condição de alteridade entre ele e os assentados. Há a gênese dessa comunidade que inclui esse agente como um dos assentados. Ele relata:

Entrevistado: Quando eu vim para o assentamento, eu era solteiro e o estágio no inicial que eu fui fazer não tinha remuneração e não tinha alimentação. Onde que eu comia? Eu comia a mesma alimentação que o pessoal tinha no acampamento! E não era por opção. Era porque não tinha outro jeito mesmo. Então, o que é que a gente comia? Arroz, feijão, ovo quando tinha, e serralha, que é uma planta que dá no campo aí. Então, eu convivi dentro das casas deles. Inclusive eu tenho um monte de pessoas lá que eu chamo de mãe. Eu tenho o monte de mãe e pai lá porque eu era... eu tinha 20 anos e era a mesma idade de alguns dos filhos deles lá, logo virou amigo... técnico e amigo, e a mesma luta e passou o tempo. Então, eu me considero um deles. Então, eu sei como eles pensam. Eu sei como eles agem. Eu sei tudo. Entendeu? Eu aprendi. E eu não sou muito diferente, porque eu aprendi isso, né? Então, quando você vai nessas coisas aí, muito filosófica assim, e aliás eu acho que eu sou um filósofo, porque tem hora que eu solto cada coisa que eu... pelo amor de Deus, nem eu acredito... Mas quando você convive com as pessoas, mas convive na intimidade da família mesmo, entendeu? Dos problemas que eles têm, eles contam tudo. A gente vira uma família mesmo. E imagina a quantidade de famílias que eram inicial, eram mais de 150 famílias. E todos me recebiam é... final de semana quando eu perdi meus amigos, por causa do trabalho, eu não ia mais pra cidade no final de semana. Eu ia no jogo de futebol junto com eles [os acampados] que jogavam nas comunidades vizinhas e dormia na casa deles. Nas festas iam juntos, né? Trabalho é trabalho, festa é festa, jogo é jogo e se passou aí trinta anos! 
Outro ponto importante da aceitação da formação da ação coletiva por parte dos assentados em seu conjunto é a atribuição aos agentes do ITESP de uma autoridade técnico-científica da gestão das experiências de produção e de comércio vividas no assentamento. Isso pode ser demonstrado pelo apelo dos assentados ao seu auxílio, não apenas quanto aos temas dessa atuação, como também aos de conhecimento processual burocrático de regularização e acesso a recursos.

\subsubsection{Das concepções de cooperação nos movimentos populares}

Um dos trabalhos mais relevante sobre o estudo do desempenho da proposta de cooperação do MST é o de Pedro Ivan Christoffoli. Trata dos temas da relação de associação, de cooperação, dotação de recursos, hierarquia, organização, militância, a questão da democracia na cooperativa e os seus problemas de gestão (Christoffoli, 2000) $\square$.

Basicamente, os estudos de teorias das organizações concebem que a própria ideia de gestão imprime em si que os espaços sociais em que se dão a esfera da decisão e a da execução não podem ser dissociados. Nesse sentido, o que se pode entender é que há arranjos entre as agrupações e seus indivíduos que podem estar em ambas as esferas, em uma, ou em outra.

É dessa forma que se entende a ideia de que a concepção da gestão e da formação da hierarquia entre um e outro é gerada. Para o autor, a intervenção da gestão na produção é dada pelas formas de: autogestão, heterogestão, cogestão e gestão participativa.

Entende-se aqui o poder explicativo de tais categorias por Christoffoli. Porém, ao se tomar as concepções tomadas por ele, opta-se aqui por apresentá-las não em relação às suas formalidades legais, o que não permitiria sua generalização, mas sim as consequências dessas concepções nos níveis da interação social e da decisão social em gestão.

A autogestão é a forma de gerenciamento na qual as decisões são tomadas pelo grupo que as executa. Nesse ponto, o que se pode considerar é que não há uma 
estratificação social entre os agentes dada por critérios técnicos, tendo em vista que se supõe uma gestão não dissociada da atividade laboral ou produtiva.

Já a heterogestão é a forma clássica da gestão numa sociedade de classes, assim como numa sociedade capitalista. Parte da concepção de que os espaços sociais da tomada de decisões e da execução dos comandos da atividade do trabalho são distintos. A heterogestão é, sobretudo, a expressão clara da divisão social do trabalho entre trabalhadores e gestores, supondo a tendência de uma especialização das funções dos agentes envolvidos, além de ser acompanhada de uma tendência correlata de estratificação social.

O pensamento clássico da Escola Científica de Administração se baseia nessa concepção de gestão. Com isso, há a justificativa da posição hierárquica de um gestor, ou administrador numa determinada organização.

Assim, a ideia da formação do comando que pode se dar entre uma esfera e outra, ou uma em relação à outra, leva à acentuação das contradições de objetivos. Dada a lógica da especialização, decisão e execução passam a ter respectivamente grupos especializados, diferentes e cada vez menos congruentes. Leva-se então à ideia da formação da posição hierárquica a partir da dominação da esfera da decisão.

É a partir de uma reflexão crítica dessa perspectiva da organização do trabalho que surge a ideia da cogestão, seguindo o raciocínio da apresentação de Christoffoli. Nesse ponto, cabe aqui uma referência a dois teóricos das organizações abordam o tema da gestão e de sua representação diante de seus membros. Isso se dá pela importância que tiveram no debate e sua repercussão nos próprios ambientes sindicais e da esquerda. Um é Fernando Costa Prestes Motta, em seu livro Participação e Cogestão (Motta, 1982) $\square$.

Prestes Motta coloca que a cogestão é uma forma de codecisão. Em outras palavras, a cogestão seria, na teoria da economia das organizações, o equivalente aos direitos de decisão. Para o autor, ela implicaria na noção de democracia na organização, o que possibilitaria inferência de grupos externos ao quadro dirigente. Surge daí a necessidade de criação de espaços sociais na organização que propiciem esse tipo de gestão conjunta. 
É a partir dessa noção que se abre a concepção da participação em uma forma de gestão que concilie os interesses de gestores e trabalhadores, que em concepções marxistas implicaria uma oposição entre eles. Dessa forma, a ideia de uma participação da representação dos trabalhadores deve compreender a formação de um interesse comum a partir da estabilidade das suas próprias relações.

O segundo teórico é Maurício Tragtenberg, que trata das origens da formação da concepção a respeito da cogestão. Nesse sentido, cita-se o caso alemão de cogestão em que há uma relação entre a participação dos trabalhadores (executores) na esfera da decisão e um comprometimento por parte da representação dos trabalhadores em manter a discrição sobre os fatos conhecidos a partir do acesso à gestão. Essa forma de conceber a relação laboral transforma a questão da transparência ou da accountability dessas relações (Tragtenberg, 1980) $\square$.

Assim, Tragtenberg expõe um ponto fundamental da experiência alemã que é a concepção correlata entre a codecisão e cooperação em os diversos âmbitos da atividade organizacional. São, por sua vez, elementos indissociáveis que mitigam essa contradição.

Por um lado, concebe-se claramente que há necessidade de acesso e comunicação entre uma esfera e outra. Por outro, entende-se que é necessária uma política de gestão das informações a fim de guardar ou defender a posição da firma em uma situação concorrencial de um ambiente competitivo.

Já em outro texto, sobre as coletivizações que ocorreram na Espanha entre 1936 e 1939, Tragtenberg, ao explicar os desenvolvimentos da experiência espanhola, pontua diversos problemas de representação que as organizações sindicais e os partidos têm ao empreender sua luta pela transformação social reivindicando a representação popular. Assim, ele apresenta o seu caráter crítico à burocracia enquanto estratégia das organizações (Tragtenberg, 1987) $\square$.

Por fim, Christoffoli trata da gestão participativa em que a noção de democracia, assim como apresentada por Prestes Motta, acaba incorporada na organização. Ela trata não da questão de uma incorporação de partes integrantes a um novo tipo de tomada de decisão de uma organização que conforma a firma em seu conjunto, mas sim a ideia de 
que a gestão como executora das decisões tomadas acaba por manter canais de participação de todos os envolvidos e, por suas ações, influenciados.

Nesse trabalho, especificamente, ele aponta para algumas considerações às quais se deve retornar. Uma delas é a de que já em 2000 apontava a insustentabilidade dos negócios das cooperativas de produção coletiva (Christoffoli, 2000) $\square$.

A partir da concepção participação e da ideia de gestão elaborada em teoria das organizações, pode se considerar que o campo de estudos a partir do conceito de agribusiness em Harvard restringe-se à dimensão da heterogestão (Silva, 1996) $\square$. Isso se dá por encampar-se em uma perspectiva externa da organização das transações em um meio agrícola.

Christoffoli tratou posteriormente do conceito de cooperação em Marx, como sendo basilar para que se empreendessem estudos históricos sobre o associativismo e o cooperativismo no Brasil (Christoffoli, 2015) $\square$. O autor entra em acordo com a interpretação marxista da cooperação, mas, além disso, constata-se que, tanto a concepção, como a realidade que Marx descreve nessa passagem tem que ver com um mundo de uma realidade que ganha, cada vez mais, contornos industriais e que, nesse sentido, a integração do "agente que coopera" na organização se dá em torno ao problema de sua coordenação baseada numa alienação que o individualiza.

É na atividade produtiva que cada vez mais se especializa que se observa a ideia de que, ao alienar-se do processo produtivo geral, o indivíduo perde a capacidade de emancipar-se ou, em termos hirschamnianos, sair da organização. Assim, a própria ideia de cooperação como pensada, pode, por essa razão, não ser fidedigna ao fenômeno o qual ela expõe.

No entanto, o desafio da forma de organização frente à ideia da cooperação enquanto trabalho coletivo e a sua relação com o MST e seus valores são apreciados por Aldiva Sales Diniz e Bruce Gilbert (2013). Os autores recuperam a formação da ideia da cooperação e de sua relação com a coletivização como concepções correlatas:

A long consultation process followed Morais's workshop (see Ribeiro 27), resulting, in June 1990, in the announcement that the MST would attempt to collectivize all its settlements (Branford and Rocha, 2002: 92). Production cooperatives were set up and then linked to state-level coordinating bodies the goal of which was to \$timulate and define the different possibilities for the development of the principles of cooperativism and to organize settlers to 
produce with access to credit, technological innovations, and the popular $m$ (Scopinho and Martins, 2003: 126). The cooperatives and coordinating bodies were given much-needed intellectual, technical, and organizational support at the national level, beginning in 1992, by the Confederação das Cooperativas da Reforma Agrária do Brasil (Confederation of Agrarian Reform Coopera Brazil-CONCRAB). In 1993 the MST set up its first cooperative training course in Braga, Rio Grande do Sul, and it became part of the Instituto Técnico de Capacitação e Pesquisa da Reforma Agrária (Technical Institute of Training and Research on Agrarian ReformITERRA). Together these bodies constituted the MST's Sistema Cooperativista dos Assentados (Cooperativist System of Settlements) (Cardoso, 1994:140). According to the Jornal Sem Terra (April/May1990, cited in Wolford, 2010: 236), settlers were encouraged to identify their membership and interests, to valorize the work of everyone, to create a division of labor that would maximize production, to live close together, to maintain individual plots of land but work them only for a predetermined limited amount of time per week, to establish administrative organization including time sheets, to divide income by work time, to create production plans, to establish links with other cooperatives and CONCRAB, and to create and enforce the internal rules that would govern their cooperatives. (Diniz \& Gilbert, 2013, p. 22-23).

Um esforço para alicerçar estudos posteriores sobre a natureza do associativismo e do cooperativismo no Brasil é o de Pedro Ivan Christoffoli (2015), citado acima. Nele o autor propõe uma interpretação com base no pensamento de Marx sobre a organização do trabalho e sobre a cooperação (Christoffoli, 2015).

O mais recente trabalho que trata o problema da gestão das cooperativas ligadas ao MST é Dualidades de Práticas Gerenciais e Político-Sociais em Cooperativas de Reforma Agrária Ligadas ao Movimento dos Trabalhadores Rurais Sem-Terra (MST), de Câmara, Mota, Marques, \& Spinosa (2016). Através de uma pesquisa orientada pela ideia de que há uma diferença entre a atuação de movimentos sociais no trato das atividades enquanto empresa, entende-se aí a existência de uma dualidade gerencial.

Segundo os autores, tal dualidade se dá pelo fato de que as cooperativas em movimentos sociais são tomadas como "empresas sociais". Nesse sentido, o que cabe ser observado é que, novamente, toma-se a sua agenda enquanto movimento político às questões da formação e da organização das cooperativas:

Esses objetivos estão divididos em três tipos: orgânicos, sociopolíticos e econômicos. Os objetivos orgânicos estão relacionados à organização dos assentados, à massificação das organizações e à politização das ações. São alguns dos objetivos: a) consolidar a organização de base do MST; b) desenvolver a consciência política e social da base do movimento; e c) 
transformar a ideologia do camponês: substituir o "meu" pelo "nosso" e mudar o aspecto artesanal de trabalhar e enxergar o mundo. Os objetivos sociopolíticos dizem respeito ao caráter transformador que o movimento pretende dar ao modelo cooperativista, por exemplo: a) vincular-se a um projeto estratégico de mudança da sociedade, e, portanto, de luta; b) ser uma forma de resistência ao capitalismo; e c) contribuir para a construção do "Homem Novo" e da "Mulher Nova", ou seja, pessoas responsáveis, politizadas, culturalmente desenvolvidas, solidárias e fraternas umas com as outras. (Câmara et al., 2016, p. 427).

Dessa maneira, o sentido político que o MST imprime em suas ações acaba levando, em sua disputa contra o sistema capitalista de produção, à conformação da organização, de seu caráter político, enquanto elemento de poder, sendo ela, na forma "complexa" de cooperativa, a alternativa que se encontra para tal empreitada.

No entanto, como se pôde observar até então, os problemas para o sucesso de projeto que se pretendam como alternativa não se limitam somente a problemas de sua posição na cadeia produtiva ou de mercado. Cabe aqui um retorno ao pensamento sobre a cooperação enquanto tal alternativa, mas que tenha relação com os estudos de campo precedentes.

\subsection{BREVE RETORNO AOS ESTUDOS DA COOPERAÇÃO E DO COOPERATIVISMO NO BRASIL}

Em seu livro Cooperativismo e Comunitarismo, Vamireh Chacon (1959) trata da relação entre a questão da formação da mobilização da coletividade em torno ao problema de sua ação. Assim, Chacon expõe as ideias de cooperação e das relações de sua condição diante da formação social de uma coletividade, nas quais propõe que o comunitarismo seria como uma proposta de transformação institucional que, através da superação do cooperativismo enquanto doutrina, conseguiria suplantar os problemas do estatismo, de inspiração marxista, e do corporativismo $\square$.

Dessa maneira, Chacon expõe as ideias do prenúncio do comunitarismo e de sua relação com o cooperativismo ${ }^{14}$. Apresenta o comunitarismo como sendo, à época, a

${ }^{14} \mathrm{O}$ uso do termo comunitarismo também existe atualmente, mas com uma conotação distinta da do problema tratado por Vamireh Chacon. Esse termo é usado por autores como Amitai Etzioni, autor 
elaboração de uma alternativa que, ao se opor ao desenvolvimento do domínio do capital, também preveniria incorrer nos erros do desenvolvimento do socialismo à sua época. O autor explica:

Por conseguinte a propriedade privada está em crise, reconhecem quase todos, e adotamos este princípio como nosso inicial 'motto' ou 'working idea'. O principal, porém, é saber como sair do dilema. Apontamos as vantagens do comunitarismo, porém pode-se indagar onde ele tem tido êxitos em grandes proporções. Insistimos que essas vastas proporções de êxito não. (Chacon, 1959, p. 29).

No entanto, cabe observar que os movimentos aos quais Chacon faz referências são de cunho social, sobre o qual a concepção da comunidade se faz através de uma compreensão metafísica, que ele compreende como sendo religiosa, mas não confessional, com inspiração cristã, mais precisamente da doutrina social da Igreja. É a partir das estruturas comunitárias fundantes, nas quais se organiza a sociedade em seu conjunto, que Chacon localiza a condição desse movimento:

O estatismo redunda, em última instância, no capitalismo de Estado, isto é, no predomínio do Estado enquanto detentor do capital, apoiado na sua burocracia e meios de coação. O comunitarismo, pelo menos no momento, apresenta-se como o caminho para superá-lo, desde que aquele se encontra em via de ascensão, embora ainda em luta contra o capitalismo liberal e neoliberal. (Chacon, 1959, p. 31).

Chacon constata a existência de estruturas comunitaristas no Brasil, como no caso do mutirão, visto como um trabalho coletivo e solidário da tradição rural. Porém, o autor aponta para o enfraquecimento dessas estruturas por conta do avanço de um sistema individualista impresso pelo desenvolvimento do capitalismo no campo brasileiro.

clássico da teoria das organizações para os estudantes de administração no Brasil. Nesse sentido, não se deve confundir a preocupação entre os objetivos dos usos por cada um. Chacon trata do comunitarismo enquanto um movimento cujo elemento condicionante se dá por meio do fundamento moral e da relação das alternativas à concepções de cooperativismo desprovidas deste fundamento. Já Etzioni propõe o uso do comunitarismo como uma proposição de transformação social e política, com implicações na política internacional ao conceber a partir de uma noção da superação das contradições sociais por meio de uma política de elevação moral do indivíduo diante das transformações capitalista que acabam por enfraquecer os laços comunitários, mas não dentro de parâmetros dos estados nacionais. Assim, o significado da concepção moral para a constituição da proposta comunitária entre um e outro é distinto, sendo indevida a aproximação de ambos. 
É dentro da condição de cativo do desenvolvimento capitalista que ele se apresenta como uma alternativa ao seu espelho oposto, o estatismo socialista. Chacon avalia à época essa condição do cooperativismo como meio de transformação dessa maneira:

\begin{abstract}
Para o cooperativismo brasileiro cumprir sua responsabilidade num gradualismo comunitário, teria de sofrer modificações profundas, talvez impossíveis num regime democrático. Daí a repetição do dilema de fazeremse, pacificamente, reformas de estrutura nos países subdesenvolvidos. O problema não consistiria, então, num mero 'golpe', ao modo dos 'pronunciamentos' e ditaduras latino-americanos, e sim numa nova orientação, capaz de transmitir a ideologia de uma 'elite' comunitarista até o povo, educando-o. O problema desdobra-se a ponto de transformar-se, em nossos dias, numa remota possibilidade, digna apenas de estudo e não de realização em futuro previsível (Chacon, 1959, p. 94).
\end{abstract}

Nota-se aqui que a relação entre comunitarismo e cooperativismo estabelecida por Chacon implica uma transformação gradual e, pode-se dizer, institucional, das interações entre os agentes sociais, que só poderia se dar a partir da atuação da vontade de uma determinada autoridade. O sentido de correção do cooperativismo que a proposta comunitarista aponta à época acaba por, na verdade, ao incompreender as suposições econômicas da cooperação, ser igualmente uma doutrina alternativa, limitada ao âmbito da proposição da organização cooperativista, mas com uma inspiração de diferente natureza.

Diferentemente da maior parte dos estudiosos de até então, que acabavam por não analisar as condições econômicas desse tipo de interação, Lenita Correa Camargo foi uma das discípulas diretas da missão francesa de formação de professores na USP, incorporando-se ao corpo docente no cargo de professora assistente do professor Dorival Teixeira em 1946, no momento da fundação da Faculdade de Economia e Administração da Universidade de São Paulo (FEA-USP). Era oriunda das ciências sociais e foi uma das primeiras professoras a se tornar catedrática durante a reforma universitária em 1970.

Ainda que seja pouco lembrada nos dias atuais, inclusive em relação aos estudos sobre o cooperativismo, Lenita pode ter sido a primeira autora a tratar sistematicamente do problema da cooperação e do fenômeno do cooperativismo no Estado de São Paulo, integrando à sua pesquisa em campo dados quantitativos e uma perspectiva analítica microeconômica sob uma clara influência dos estudos da Escola de Negócios de 
Harvard. Nesse sentido, diferentemente do trabalho científico de outros autores que se atentam à apreciação doutrinária do cooperativismo enquanto proposta dada à ação coletiva dos determinados proponentes, referidos como teóricos, ou defensores do que se configura enquanto um verdadeiro movimento, Lenita observa a unidade econômica e seu tomador de decisão enquanto um agente relevante para o efeito de uma conflagração do fenômeno, ou não, do cooperativismo.

A princípio, Lenita considera a cooperação não enquanto um conceito claro, ou um fenômeno do qual se possa trazer uma definição a priori que possa ser corrigida ou aperfeiçoada posteriormente, em termos evolucionistas, de forma a revisar a compreensão de Darwin e Spencer em seus sentidos sociológicos. Trata, antes de qualquer outra pretensão da construção do conhecimento humano, da cooperação enquanto uma noção.

Lenita compreende a relação entre concorrência e solidarismo, e entre competição e solidariedade, como elementos constituintes de uma solidariedade social a qual contém em si a divisão do trabalho e o fenômeno da cooperação. É a partir da relação de um contraditório reconhecido de interesses que a autora concebe a ideia de cooperação, dada a relação constituída pelas partes a partir da formação de uma consciência coletiva, dentro de uma concepção durkheimiana.

Para Lenita, à mesma maneira de Ostrom, a reciprocidade tem um papel, fundamental na cooperação e nos mecanismos de ajuda mútua no campo paulista. Ela compreende que essas são formas de cooperação espontâneas, que acabam sendo marginalizadas ou esgotadas diante das transformações sociais vividas pela comunidade estabelecida.

Entende ainda que a cooperação é um fenômeno que emerge da ação conjugada, ou seja, da ideia de que, é por funções específicas — dada a condição de um trabalho social dividido- que se mantém a cooperação. Nesse sentido, ela passa a ter um elemento evolucionário no sentido de que essas relações estão permeadas por fatores afetivos, identitários, vicinais e mesmo os de ordem processual, como hábitos e rotinas.

Porém, diante desse elemento de mudança, Lenita concebe também a estabilização das relações sociais, o que seria, no caso, a ação padrão. Essa estabilidade se dá por uma superação das subjetividades dos agentes da interação, no sentido de criar 
uma base objetiva comum que conforme a ação política, que em seus termos se trata, de fato, da questão primeira a respeito da ação coletiva.

Com isso, é a partir de um elemento de mudança, de diferenciação entre os agentes sociais, somado a um elemento de equalização das ações desses agentes, que Lenita passa então a formar suas concepções de cooperação e cooperativismo. Para ela, o fenômeno observado e a atribuição feita a ele em sua denominação enquanto cooperação e cooperativismo, não tem uma relação que ajude sua compreensão.

Assim, ela compreende que a cooperação é um fenômeno sobretudo espontâneo, dadas as condições sociais da ação dos seus agentes, enquanto o cooperativismo se trata de um fenômeno artificial, implicando um sentido de transformação social:

\begin{abstract}
1- Quanto à cooperação: a) é sinônimo de ação conjugada e se define como a disposição dos indivíduos dentro de um grupo ou de vários grupos sociais para, sob certas condições, agirem como uma unidade; b) resulta da divisão do trabalho e especialização das funções as quais permites estabelecer uma distinção entre as ações individuais, as ações-padrão de grupos e a açãopadrão total. Estas causas determinam, ao mesmo tempo, a solidariedade social, a competição, o conflito e a acomodação; c) os elementos integrantes da cooperação são: a morfologia, a integração e o controle sociais; d) é um fenômeno social espontâneo apresentando, portanto aspectos que refletem as maneiras de pensar, sentir e agir dos grupos em que se verifica. 2- Quanto ao cooperativismo: a) no sentido restrito significa o conjunto de grupos de atividade resultante da união voluntária de pessoas, em bases democráticas, para suprir seus membros de bens ou serviços, seja para empregá-lo na produção para venda ou para vender seus produtos, seja para financiá-los ou ainda para combinar todos esses três objetivos em um só e, ao mesmo tempo, distribuir, de maneira previamente discutida e aceita como equitativa, os proventos dessas operações; b) no sentido amplo se definiria como a corrente de pensamento doutrinário visando a reorganização social, graças ao econômico, pelo associacionismo resultante da conscientização da solidariedade social, tendo por substrato uma filosofia de vida, o solidarismo, e uma finalidade, a reforma social, pela mudança gradativa do sistema econômico capitalista; c) o tipo de associação e solidariedade apregoado pela doutrina cooperativista é finalista, consciente e previamente organizado dentro de um conteúdo normativo e lógico, ou seja, uma tentativa de construir racionalmente novas ações-padrão que se sobreporiam àquelas espontaneamente nascidas. (Camargo, 1960, p. 133-134).
\end{abstract}

Podemos então compreender que é essa transformação social, da artificialidade do cooperativismo, que está em disputa em seu aspecto doutrinário, sendo sobre ele que se dará a determinação da mudança a partir da consecução de um objetivo político. Nesse sentido, por se configurar como um elemento artificial, o que se observa é que a conformação da intervenção que será feita em seu propósito passa a sofrer ainda mais 
das contingências dos seus contextos históricos, ambientes políticos e de suas condições sociais (Camargo, 1960).

Na esteira do que é demonstrado por Lenita, Diva Benevides Pinho apresenta uma vasta obra a respeito da evolução doutrinária do cooperativismo, de suas inspirações e suas experiências. Pinho, ao reunir os acontecimentos em conjunto, propõe uma tipologia extensa a respeito da caracterização das organizações cooperativas.

Contudo, aqui cabe apreciar uma obra em especial de Diva, $O$ Cooperativismo nos Meios Capitalista e Socialista, de 1961. Ao focalizar nos aspectos doutrinários, Diva faz um esforço compreensivo acerca da relação entre a formação de uma doutrina econômica e sua condição, dadas as imposições materiais da realidade sobre as ideias.

Sob esse ângulo, Diva Benevides Pinho aborda questão do cooperativismo enquanto uma proposição autônoma, que pode existir ora no sistema capitalista, ora no socialista. Dessa maneira, o que se pode compreender é que a concepção da proposição da cooperação e de seu desafio não diz respeito necessariamente a uma mudança de regime político.

Entretanto, há condições mínimas para a viabilização da cooperação. Entre elas estão a capacidade de livre associação e a relação da formação ou não de uma organização capaz de atuar ou não em uma relação de mercado não controlado ou fechado (Pinho, 1961).

Ao comparar essas condições, Diva demonstra as contradições da formulação da doutrina diante da condição social na qual se procura manter uma proposta cooperativista. Com isso, atribui um papel à doutrina cooperativista que está em desacordo com a concepção dos fundamentos econômicos da teoria de Emelianoff.

Ainda afirma que a inserção de cooperativas em diferentes regimes políticos, como no caso da clivagem entre capitalismo e socialismo, pode gerar diferenças tanto quanto a sua adequação, como a sua proposta. Portanto, nesse trabalho específico propõe um conjunto de tipologias distintas para cada tipo de inserção social, categoria e atribuição, de acordo com os objetivos traçados pela proposição da cooperação e de seus agentes componentes. 
A autora acaba, por fim, por fazer uma análise sobre o cooperativismo, tratandoo como um fenômeno autônomo aos dois regimes vigentes, no caso o capitalista e o comunista. Dessa forma, tece considerações sobre os condicionantes em cada regime para a proposição do cooperativismo como uma terceira proposição:

\footnotetext{
De fato, no meio capitalista, não tendo a doutrina encontrado condições para a cooperatização integral, surgem as semicooperativas, cuja atividade se circunscreve, geralmente, a certos setores tais como os de economia doméstica, artesanal e campesina.

Nesses setores, como mostramos, seus resultados são limitados, não conseguindo o cooperativismo eliminar completamente nem o lucro, nem o salariado. Mas, é nesse meio que a parte normativa da doutrina, principalmente no que se refere à livre adesão e ao controle democrático, encontra ambiente mais propício à sua efetivação; no meio socialista, embora as condições sejam mais favoráveis à cooperatização total, por não haver aí os obstáculos característicos do capitalismo, a política estatal freia a atividade cooperativa limitando-a apenas aos setores em que as tentativas de coletivização, em moldes puramente socialistas, têm sido inoperantes. Representa, pois, aí um modelo organizatório que facilita a expansão do socialismo. Portanto, apesar das modificações impostas pela necessidade de adaptação aos meios capitalista e socialista, não se pode negar a importância e a utilidade do cooperativismo. (Pinho, 1961, p. 120-122).
}

Aqui se constata um erro na análise de Pinho à época, por conta da compreensão do papel doutrinário, e de sua relação com um determinado meio, como fundamental ao cooperativismo, diferentemente do que propõe a teoria de Emelianoff e as próprias observações de Lenita Correa Camargo. De fato, a compreensão do cooperativismo extrapola a elaboração doutrinária e remete a considerações de outra ordem, não aparentemente dadas e nem tão influenciadas pelas condições do regime político existente.

O que demonstra a limitação dessa compreensão doutrinária do cooperativismo enquanto objeto de análise, que foi amplamente difundida entre os proponentes desse sistema, é que, segundo as categorias de Pinho, não se consegue prever a existência de uma experiência cooperativista levada a cabo no meio capitalista que tenha como objetivo a transformação social no sentido da construção do socialismo, a exemplo da experiência soviética. $O$ ponto fundamental é que não fica claro em que medida o cooperativismo seria autônomo, se ele pode ser instrumentalizado.

É em meio ao debate doutrinário e à ideia de uma superação de paradigmas que já se pensou a própria alteração do sistema de representação do cooperativismo no 
Brasil. Paradoxalmente, a defesa dos mesmos princípios rochdaleanos, ou da parte da inspiração de outros doutrinadores, por vezes, tampouco marxistas, eram observado por trabalhos mais antigos.

Assim vem a obra de Maria Rita Loureiro (1981), Cooperativismo e Reprodução Camponesa, onde ela concebe a ideia de que a cooperativa é mais um mecanismo de subordinação do que foi concebido no debate à época como campesinato. Porém, essa concepção, ainda que expresse sensibilidade, dado o tema diante de uma população que poderia ser expropria, tem a sua argumentação levada à manutenção doutrinária da organização:

\begin{abstract}
Rompimento com os chamados princípios doutrinários do cooperativismo (tais como igualdade de sócios, sistemas democráticos de participação e gestão, etc.), colocando o controle das cooperativas em mãos de uma minoria que se autoperpetua nas diretorias executivas e conselhos de administração. Assim, seu Artigo 47 regulamenta que o Conselho de Administração - órgão fundamental na estrutura das cooperativas, de onde saem os diretores executivos - seja renovado de três em três anos em apenas um terço de seus membros. Os outros dois terços constituem, portanto um grupo de dirigentes com tendência a perpetuar-se, posto que as renovações, além de parciais, não estão reguladas pela cláusula de do rodízio. É por isso que deparamos com cooperativas cujos diretos se mantêm em seus caragos há mais de vinte anos, dando azo aos chamados 'donos das cooperativas', como indicou Rios (1974) para o Nordeste (Loureiro, 1981, p. 137).
\end{abstract}

\title{
5.7 A ESPECIFICIDADE DO MOVIMENTO SOCIOTERRITORIAL
}

Por fim, tomamos a questão do sistema de incentivos do quadro dirigente do movimento social que, diante das unidades familiares, acaba por ter uma interação distinta. Nota-se aqui a ideia de que haja uma especificidade desse fenômeno quanto à formação de um movimento socioterritorial. O debate em geografia a respeito dos concebidos como "movimentos socioterritoriais" é sintetizado em Nelson Pedon (2013):

No que se refere à natureza territorial e territorializante dos movimentos sociais, que podem ser considerados socioterritoriais, deve-se, num primeiro momento, considerar a lógica de expropriação que faz que esses movimentos tenham a ocupação como estratégia de resistência. Esse fato decorre do questionamento que a ocupação impõe, no nível local, a uma ordem estabelecida por processos que estão organicamente vinculados ao desenvolvimento mais amplo do território do capital. A ocupação corresponde a um conjunto de práticas sociais que constroem e estruturam o 
movimento socioterritorial. A ocupação é, portanto, uma prática definidora do movimento socioterritorial. (Pedon, 2013, p. 149).

De fato, esse tipo de fenômeno de movimento socioterritorial acaba por conformar uma relação de sistema de incentivos entre a direção do movimento diante dos demais integrantes que parta do princípio de que, ao engajar-se na luta social pela conquista da terra, há a concepção de uma consequente concessão dela ao integrante. Por isso, ao se organizar pela luta quanto à apropriação, ou expropriação, de ativos disponíveis esse tipo de movimento, consegue manter um mecanismo de hierarquia sustentável também do ponto de vista de ganhar funcionalidades e capacidades no nível da atividade da organização.

Porém, a evolução desse tipo de movimento não prescinde necessariamente dos instrumentos de ocupação e acampamento. Uma vez que o grupo alcança um determinado tipo de estabelecimento, como no caso de movimentos socioterritoriais de reivindicação do acesso à moradia em zonas urbanas, a lógica da ação coletiva, assim como o propósito de sua mobilização pode mudar, segundo a dotação de recursos presentes dos membros que a iniciaram e que em alguma medida seguem na organização.

Em um estudo mais específico sobre os movimentos socioterritoriais no campo, José Sobreiro Filho (2013) trata do fenômeno das lutas pela terra a partir dos estudos destes, por meio das ocupações no Pontal do Paranapanema no Estado de São Paulo. Observa a relação da formação desse tipo de movimento, a partir do exercício da ocupação e de sua interação com empresas, partidos, ONGs e com a Igreja, esta neste caso à época, dado o caso por ele estudado (Sobreiro Filho, 2013) $\square$.

É nessa interação que, assim como existiam movimentos precedentes ao próprio MST no caso da disputa pela terra no campo no caso do Pontal do Paranapanema, as propostas dessas organizações levam a disputas entre projetos e objetivos a serem buscados pelos grupos de mobilizados em seu nível local. No caso, não apenas as diferenças internas do MST acabaram levando à formação de outros grupos, como também o contato com agrupamentos afetados pela sua atividade, levou à formação de outros movimentos lá: 
As primeiras ações realizadas por um movimento que não fosse o MST ocorreram em 1996, com o surgimento do Movimento Brasileiros Unidos Querendo Terra (MBUQT), também denominado Associação Brasileiros Unidos Querendo Terra (ABUQT). De acordo com Maciel (2009, p. 2) o MBUQT/ABUQT foi criado por um grupo de arrendatários do município de Presidente Venceslau que trabalhavam e tinham sua fonte de renda nas grandes fazendas da região. $O$ autor também aponta que o movimento foi constituído por um grupo de arrendatários com a finalidade de se opor às ações do MST visto que, com as consequentes desapropriações ocasionadas pela luta do MST na região, as relações de arrendamento foram prejudicadas e, portanto, o grupo se sentiu atingido. Assim, o grupo se organizou a passou a também lutar pela terra, ou seja, pelo seu lote. Sobre a organização dos trabalhadores, Maciel (2009) apresenta um trecho de entrevista de fevereiro de 2007 com o Geraldo Lopes, presidente da associação/movimento sobre o MBUQT/ABUQT:

\begin{abstract}
O Movimento surgiu porque nós éramos... Eu principalmente, eu fazia parte da... eu era arrendatário e quando o movimento dos Sem-Terra vinha para cá, foi muito difícil as pessoas adquirirem terra para o fazendeiro arrendar para a gente, arrendar a fazenda do fazendeiro. O que acontece é que, já que o Movimento ia pegar terra de graça e atrapalhando os arrendatários, o que acontece: nos reunimos primeiramente com uns 7 (sete) arrendatários para nos ocuparmos a fazenda Primavera. No dia em que eu fui para ela, tinha mais de 500 pessoas, foi aí que surgiu o movimento Brasileiros Unidos. (Maciel, 2009, p.2, citado por Sobreiro Filho, 2013, p. 250).
\end{abstract}

Assim, pode-se afirmar que os mecanismos de operação das funções em uma organização, tem relação com a alteração dos elementos de barganha entre as partes, ainda que nesse estudo não se possa determinar as variáveis e a formação da sua relação. O próprio Nelson Pedon (2013) verifica essa alteração da atividade do grupo diante de uma transformação:

Não obstante a heterogeneidade presente no conjunto dos movimentos socioterritoriais que atuam nas cidades, os problemas decorrentes da aguda exclusão social unificam suas demandas. Dentre esses movimentos, a luta pela moradia tem centralidade nas suas agendas. Na década de 1980, a Associação dos Trabalhadores Sem-Terra (AMST) de São Paulo já realizava ocupações antes mesmo da visibilidade conquistada pelo MST. Atualmente, as ocupações não fazem mais parte da agenda desse movimento, suas práticas se voltaram para a organização dos moradores de áreas pobres, para que esses possam adquirir um lote e construir sua moradia. Contando, para isso, com o 
auxílio da Companhia de desenvolvimento Habitacional e Urbano (CDHU). Outros movimentos possuem agendas parecidas, como a Unificadora de Loteamentos, na Zona Leste e o Movimento de Regularização na Zona Norte. (Gohn, 2007, citado por Pedon, 2013, p. 214).

É sob essa perspectiva que se consegue tomar ou dirigir a ação coletiva diante da construção dessa reciprocidade. Porém, a questão é que o mesmo quadro dirigente não consegue manter um sistema de trocas sociais no qual, uma vez delegada a terra, se mantenha essa reciprocidade.

Dessa forma, é a transformação dessa lógica a partir da compreensão dos elementos da agricultura familiar que se compreende se a mobilização socioterritorial é capaz de se manter ligada à atividade produtiva do momento posterior à formação de assentamento. Assim, se não há uma justificativa técnica de sua posição diante do conjunto dos assentados a partir de uma determinada função, essa dinâmica de mobilização e incentivos se esvai.

O que demonstra isso no assentamento é a relação que existe entre as ações do movimento e assentados que já foram estabelecidos pela própria ação do ITESP. Estes tomam a sua relação com os movimentos de uma maneira mais distante.

\subsubsection{Observações Preliminares sobre a Configuração das Interações no Espaço do}

\section{Assentamento}

Um dos problemas da análise diz respeito à delimitação das unidades apreciadas em campo, sendo a primeira delas a própria compreensão do "assentamento".

O trabalho de Caume (2002) sobre a tessitura das relações dentro de um assentamento e de sua formação coloca uma série de problematizações e contradições existentes na vida social da população assentada que é negligenciada por estudos militantes ou comprometidos com objetivos de antemão. Ao contrário de ser um espaço de pacificação de um conflito precedente, o autor defende que o assentamento é, na verdade, um espaço de conflito (Caume, 2002).

O autor expõe diversos problemas das análises que constatam essas contradições como oposições simplistas, que tomam qualquer diferença de função, posição ou dotação como um fator de contradição no arranjo associativo. Como aqui neste caso se 
pode observar, Caume afirma que, por conta do ambiente conflitivo vivido no processo de formação do arranjo, estabelecer uma autoridade externa que consiga intervir sob a forma da heterogestão é dificultado, já que a capacidade do grupo ao disputar o espaço tem o potencial de ser utilizada no sentido de resistir a essas propostas. Quanto a esse tipo de relação Caume afirma que é:

\footnotetext{
Em outra dimensão, observei nesses trabalhos um entrelaçamento entre o discurso científico e a enunciação política, particularmente aquela professada pelo MST. Nas análises, em consequência, se verifica, repetidas vezes, que a não adesão às propostas e lutas do Movimento são (des)qualificadas como sendo decorrência da 'falta de consciência' ou 'falta de clareza'. (Caume, 2002, p. 3).
}

Ressalta-se aqui a observância em relação a esse ponto de sua análise, no sentido de extrair elementos dessas diferenças a partir dos discursos e da percepção dos agentes dessas contradições. A atribuição de contradições que estejam fora do horizonte de consciência dos agentes envolvidos só pode ser ocorrer por meio da tomada de dados de que sejam correspondentes diretos das categorias de análise que, naturalmente, reduzem a realidade, justificando-se por um fim explicativo específico.

Ao se tratar do assentamento enquanto uma unidade deve haver as ressalvas dos elementos que o compõem, como elementos de natureza física e geográfica, isto é, o diferente relevo, a disposição de vias e estradas, as próprias agrovilas, não excluindo elementos de natureza institucional, como a jurisdição municipal à qual cada agrovila pertença, como no caso, dividindo-se entre dois municípios, Itapeva e Itaberá.

Do ponto de vista institucional local, só se pode tratar de uma unidade no nível estadual e que se faça representar pela organização do ITESP como autoridade que confere essa unidade. Assim, ao contrário do que se pode supor, o assentamento já tem diferentes dotações institucionais para acesso a políticas públicas por parte dessa própria diferença. 


\subsubsection{Propostas Econômicas quanto à mudança na relação de produção}

A natureza contestatória da ordem social por parte da própria formação do assentamento se dá em meio a uma busca por afirmação social desses assentados. Nesse sentido, o que se pode compreender é que, ao procurarem se reinserir socialmente, estes acabaram sofrendo pela expectativa de um desempenho igual ou superior ao da produção empresarial de grande escala.

Vias alternativas de produção acabam sendo uma forma de proposição de sua reinserção social e econômica, decorrendo disso a busca pela legitimação de sua condição através de inovações e diferenciação em sua produção. O exemplo mais recente disso é a proposição da transição agroecológica.

Diante do domínio das grandes corporações da agricultura no mundo, formas de combate à sua supremacia emergiram por meio da busca ou da construção da autonomia dos produtores. Assim, ao compreender que o poder dessas corporações se origina do domínio dos meios técnicos e materiais de produção, a busca por autonomia passa pela substituição desse método.

A agroecologia é um simultaneamente um tipo de conhecimento humano, uma técnica de produzir e também, especialmente, um movimento social. Sob a perspectiva de seus proponentes, a agroecologia é também um fenômeno ligado ao tipo de conhecimento gerado, a partir da territorialização dos espaços pelo ser humano e da transmissão de saberes alcançados pelas gerações precedentes. Assim, ao contrário das artificialidades da forma de produção industrial, que não se relaciona ou observa os fenômenos naturais, a agroecologia acaba assumindo um caráter em favor da preservação do equilíbrio da natureza.

Porém, compreende-se que, enquanto uma reconsideração científica moderna, dada a sua apropriação pelos agentes agronômicos, a agroecologia, enquanto proposta, é a tentativa de superação da contradição constatada na antropologia clássica entre a natureza e a cultura, na atividade humana de reprodução social no âmbito da produção agrícola. Assim vem a ideia de que se se deve por um elemento cultural material, agredir a natureza, para a exploração econômica dos espaços. 
Do ponto de vista da estratégia política de sua proposição, ela corresponde a vários pontos dessa contradição. A defesa de uma alimentação saudável por meio de uma produção ambientalmente sustentável se faz pela rejeição de ingressos de insumos provenientes das grandes corporações, em favor de uma produção orgânica somada a técnicas advindas de conhecimentos ignorados pela agronomia moderna.

A defesa da agroecologia passa por aliar a isso uma intuição de mercado fundamental: a de que se consegue diferenciar a produção através do uso intensivo do fator de produção trabalho e que através disso se compensaria o produtor com um preço mais alto em mercado, além de eliminar a captura de sua renda por parte do seu fornecedor de insumos e sua assistência técnica.

A viabilidade técnica da produção agroecológica é demonstrável, inclusive com resultados superiores aos da produção convencional. Porém, do ponto de vista das necessidades sociais dos produtores e de sua sobrevivência material, a proposição da transição acaba por incorrer em várias debilidades, como por exemplo, a necessidade de inserção de sua produção no mercado, bem como a suposição da maior precificação e aceitação pelo consumidor a pretexto da sua contraparte saudável que são, se não irreais, no mínimo questionáveis.

Além disso, não se compreende por parte de seus propositores a dinâmica de apropriação de mercados e de inovações das empresas enquanto organizações com fins lucrativos. Ao contrário de resguardar ou defender um mercado, o que se faz é a criação de um novo nicho em que, à parte de seus objetivos políticos, ela reunirá os meios para a promoção da sua interação.

Com isso, a intuição acaba por não compreender a proposição da transição agroecológica com a própria existência do mercado de produtos orgânicos. Em outras palavras, o que se observa é que a resistência ou a própria recusa dos assentados em acatar essas propostas vem nesse sentido. 


\subsection{ARRANJOS PRODUTIVOS COMERCIAIS ATUAIS}

Esta parte discorre sobre parcerias, mercados institucionais, o papel da Conab e atrasos que ocorrem em relação ao pagamento às famílias. O objetivo aqui é determinar quais opções de mercado conhecidas existem para os assentados.

\subsubsection{Parcerias (Reais Ou Arrendamentos Disfarçados)}

As parcerias são a forma de associação comercial mais comum entre os assentados. Consistem numa negociação em que uma das partes cede o seu espaço de produção agrícola à outra, associando-se nos resultados da comercialização.

Mais comumente envolvem duas partes, mas nada impede que sejam mais de duas, na divisão de responsabilidades para a produção e do trabalho. Nesse ponto, a divisão do resultante é acordada entre as partes no momento do seu acordo.

Embora sendo um arranjo comercial conhecido desde o tempo dos arrendatários boiadeiros, atualmente as parcerias apresentam algumas diferenças. A princípio, há uma mudança dominial, a respeito de quem seria o detentor de direitos de propriedade sobre elas, como no caso à época das famílias que detinham essas posses, os Vicenzi, os Furlans, dentre outras. Porém, além dessa mudança, há outra, na estrutura do mercado de terras que se forma na jurisdição do assentamento. Ou seja, a terra, e o direito de sua exploração tomado como um ativo aufere a possibilidade, à parte dos agentes econômicos ali presentes, da conformação de arranjos produtivos e associativos descentralizados por conta da diferente disposição das estruturas de reciprocidade presentes no espaço do assentamento.

Ao contrário do que acontecia, com o monopólio do direito de exploração nas mãos de apenas um agente, o arrendamento que envolvia aquela relação era que a troca que envolvia a exploração do espaço, pelo respectivo pagamento, não constituía tal relação, pois havia uma assimetria expressa pela posição de dominância do mercado de terras, por parte dessas famílias. 
O pagamento pelo arrendamento diante de uma troca caracterizada por tal assimetria de poder de mercado, como no caso das terras da área do assentamento, não continha em si reversibilidade. Sendo assim, trata-se de uma troca, operada enquanto uma tributação, com característica de uma dádiva ao detentor do domínio, já que este não teria participação na atividade, mas a capacidade de substituição da exploração daquela área por outras áreas, que também era dificultada por não haver terras disponíveis.

Existem vários motivos que fazem com que a parceira seja a forma mais comum de associação agrícola. A princípio, seria por conta de uma necessidade de competitividade no mercado, ou por ganhos de escalas de produção, pela complementariedade de dotação por parte dos envolvidos.

Dentre a população de assentados entrevistados pelo questionário, as parcerias que envolvem algum mecanismo de renda chegam, entre concessores e tomadores de área, a 16\% do total. Esse número inclui assentados que tomam ou concedem áreas de produção também a agentes externos ao assentamento.

Porém, a motivação fundamental é a de que esta é a forma que facilita a legalização de uma relação de arrendamento de fato da terra, em que, na verdade, o lote é um instrumento de captura de renda por parte de seus detentores. Nesse sentido, ele, enquanto um arranjo baseado em uma forma de propriedade da terra, é um meio de auferir renda.

Por outro lado, não apenas isso. Há diversas contingências que levam uma das partes a ceder o seu lote à outra. Dentre essas estão desde a recuperação por uma invalidez ou doença que impeça uma das partes de tomar parte do empreendimento agrícola, até mesmo uma melhor forma de controle tendo vista que, dada a remuneração em dinheiro estabelecida, diminui-se os custos de coordenação na medida em que apenas uma das partes fica responsável pela produção no lote.

Dessa maneira, do ponto de vista da formação do arranjo de negociação, dada a disposição e a distribuição dos ativos pelas partes, o que se vê é a parceria nos moldes de um arrendamento, em que uma das partes cede a outra a gestão, tem a ver com a forma familiar da gestão da produção. Isso dificulta a coordenação das decisões e do trabalho agrícola, pois essa gestão se dá no modo de produção doméstico, 
principalmente quando não há organizações hierarquicamente superiores quanto à produção, ou instituições precedentes que coordenem o trabalho agrícola.

Aqui, observa-se uma contradição vista na própria política pública. Por um lado, incentivam-se programas de instrução dos assentados, para que possam desempenhar melhor a gestão de suas próprias áreas de atribuição da produção. Por outro, ao se qualificarem, acabam expandindo suas possibilidades de colocação profissional dedicando-se a outras atividades. Porém, estando na condição de assentados, eles não podem manter uma carteira assinada, o que os leva a um impasse. Como estão ligados à concessão da terra do seu lote - concessão esta vista como um privilégio pela legislação-, são impedidos de tomar um emprego não agrícola disponível na região, a fim de se manter aquela população na agricultura.

A ideologia do trabalho e a não aceitação do ócio do assentado levam a um problema insolúvel da intervenção agrária. Há um problema de agência entre o próprio governo e o assentado. Não há forma de se forçar o assentado a executar trabalhos braçais, pois a possibilidade do uso de maquinário e componentes dotados de incorporação tecnológica faz com que ele não o faça, já que passa a controlar, como apresentado por Chayanov, a autoexploração do trabalho.

Aqui se toma um relato de um agente social no assentamento, que relata o processo da atividade agrícola produtiva anual por safra. Assim ele descreve:

Entrevistado: A discussão que veio à tona era o pacotão das empresas. Foi discutido junto com a Assembleia Geral, junto com a comunidade. Pros diretores é [indicando ser uma situação suspeita de irregularidades]... porque é bastante pacotão. A maioria é pacotão. Nem assim de [em proporção ao volume de negócios feitos entre pacotão e parceria].... De parceria [em ambos sentidos, tanto a prevista em lei, como a que se regulariza em função dela] é muito pouco, não é muito. A maioria é pacotão. O que que é esse pacotão? Os diretores [da fiscalização] queriam saber se a pessoa trabalhava e é esse [ponto] que pega, mesmo na parceria e mesmo na coisa [no pacotão]. Primeiro: quem que planta? É ele [o assentado] que planta. E é mesmo! Ele contrata máquina pra fazer o plantio dele. E a semente? A semente eu assinei uma CPR [cédula de produto rural15] que eles chamam lá que [falaria o assentado] eu peguei a semente, o adubo e os defensivos agrícolas. E nesses alqueires que eu plantei eu vou pagar mil sacos de soja. Nem falando em valor, é produção. Mil sacos de soja. De 5 alqueires, mil sacos de soja.

${ }^{15}$ A Cédula de Produto Rural (CPR) foi instituída pela Lei $\mathrm{n}^{\circ}$ 8.929, de 22 de agosto de 1994, pelo então presidente Itamar Franco. Tratava-se de colocar sob o amparo legal uma concessão de crédito feita por agentes econômicos, incluindo associações e cooperativas, para a manutenção de sua atividade produtiva. 
[interpretando o fiscalizador] 'Mas quem planta é você?' [respondendo como o assentado] 'Eu mesmo não, porque eu não sou tratorista, mas eu pago o cara pra fazer o plantio, pra fazer bem feito, né?' [novamente interpretando o fiscalizador] 'A pulverização é você que pulveriza?' [respondendo novamente como o assentado] 'Não. Eu também pulverizar, não pulverizo.' [fiscalizador] 'Por que?' [assentado] 'Porque tem uns caras aí que faz serviço, prestação de serviços, eles faz o serviço e eu pago pra eles, pra eles pulverizar. Eles cobram tanto o alqueire.' Se o Estado falar assim, que quer que o cara trabalhe, ele não consegue porque é tudo maquinário! Na nossa região aqui é grãos. É tudo maquinário. O único [serviço] que tinha na mão que era de arranque de feijão tal, hoje tem a máquina que colhe o feijão. Então nem esse serviço não tem mais. E o que que você quer que ele faça? [interpretando o discurso do Estado] 'Quero que o assentado trabalhe ainda!'. Aqueles que querem ficar um pouco melhor [se referindo à renda]. Porque, imagine, você planta 5... 6 alqueires de soja, que é a área total deles [do lote]. Ele vai lá ver se tem bichinho, né? $\mathrm{Na}$ hora do plantio, ele vai lá acompanhar. A pulverização, aí tem que ficar meio longe porque fica cheio de veneno, né? [1 ou 2 dias] Aí ele vai lá vê se tem bichinho, pulveriza e volta quinze dias depois pra ver se não voltou as pragas. Aí ele vai lá pra colher. Pra acompanhar a colheita. As pessoas que falam assim 'não [se referindo ao trabalho]' folga 5 meses no ano. As pessoas que querem tirar um dinheiro extra, ele planta meio alqueire de quiabo que dá uns seis meses de serviço lascado.

Entrevistador: Você nota pelas mãos.

Entrevistado: Exatamente. Você entendeu? Aí essa pessoa, logicamente, ele tem um carro melhor. Por quê? Não dos sacos de soja que deu pouco dinheiro. Dá 10, 15 mil [reais] aí os 5 alqueires, mas ele tirou 25 mil [reais] no quiabo que ele plantou.

Há uma associação entre a ideia de trabalho e a de sofrimento. Há uma incriminação dos assentados como consequência dessa ideia da relação entre a "concessão" como um dote, dádiva e a visão sobre o desempenho dos assentados.

No caso da constituição de uma falsa parceira, o assentado é acusado de absenteísmo pelos críticos a essa determinada política de assentamentos. Porém, o assentado, em alguma medida, é ligado à terra pela via institucional, já que possui o ativo da concessão, com a qual ele mantém esse direito de apropriação de renda, desde que se verifique que ele lá habite.

O próprio ITESP encampa-se em uma campanha para o combate às falsas parceiras. Apesar de haver um histórico de punição e mesmo de perda da concessão ao lote, a atuação do ITESP, ao ignorar determinadas condições no assentamento, acaba desgastando-se no seu papel de intermediador das relações no assentamento, e sendo também uma ameaça aos assentados. 
Figura 13 - Cartaz da campanha no ITESP contra os arrendamentos

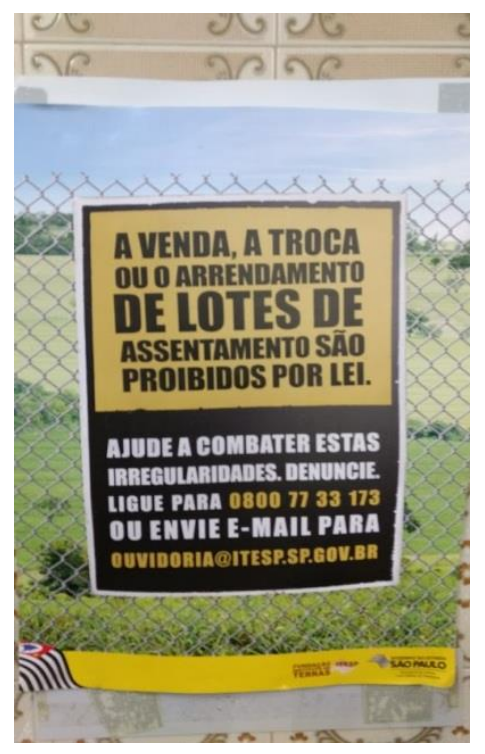

Constata-se, a partir de relatos e da observação em campo, que também existem casos de assentados que chegam a arrendar terras fora do assentamento. Nada impede essa relação. Diferentemente do que se se vê entre os próprios assentados, que acabam procurando subterfúgios para legalizar a mesma relação, não se teve contato com nenhum estudo que se depare com o fenômeno e a sua relação na estrutura de mercado de terras quanto a esse tipo de negociação e suas consequências sociais e econômicas.

\subsubsection{Mercados institucionais}

Em meio ao conjunto de políticas de apoio à agricultura familiar concebeu-se um conjunto de programas de aquisição da produção com a finalidade de viabilizar sua atuação no mercado, um deles sendo o de financiamentos através do Programa Nacional de Fortalecimento da Agricultura Familiar (PRONAF).

A relação do PRONAF com os empreendimentos no assentamento é tratada por um relatório do IPEA de 2013. Nele se expõe a situação dos assentados diante desses programas de incentivos e, a partir de uma avaliação em dois momentos, nos anos de 2006 e 2010, pode-se observar sua evolução, inicialmente na pesquisa de 2006, a seguir:

$\mathrm{Na}$ época, a pesquisa assim definiu a situação encontrada: "O endividamento foi constatado em, praticamente, todas as áreas visitadas. Nas diversas entrevistas, prevaleceu a informação de que predomina a inadimplência, a 
impossibilidade de acesso a crédito oficial e dependência do crédito informal sob diversas formas - fornecedores de insumos, vendedores de gado, acertos com as agroindústrias etc. Em algumas entrevistas, foi reconhecida a ação do Incra no encaminhamento de negociações. No caso do Banco Nossa Caixa, as dificuldades foram consideradas mais graves (maiores). O PA Pirituba II em Itapeva é exemplo claro dos impasses causados pela situação de inadimplência. As demais ações lá levadas e efetivadas pelo Incra perderam em eficácia e, em decorrência, frustraram expectativas. (Disoc/Ipea), 2013, p. 81).

Já em sua reavaliação na pesquisa de 2010, o relatório acaba por confirmar sua condição. Assim, se expõe esse resultado:

\begin{abstract}
A situação encontrada em 2010 não invalida as conclusões da pesquisa de 2006. Pelo contrário, as reafirma. Existe inadimplência em vários PAs de reforma agrária. Não obstante, cabe uma importante ressalva: a pesquisa verificou que houve grande empenho do Incra no encaminhamento de negociações para resolver difíceis situações de casos de inadimplência coletiva, e que em várias ocasiões esta atuação resultou exitosa: Promissão (PAs Fazendas Reunidas e Dandara) e Itapeva (PAs Pirituba) foram citados. Outra ressalva importante refere-se à maior celeridade da política para os assentamentos novos. Uma das consequências positivas deste fato é evitar o crédito informal, que comprometeria o PRONAF A e a viabilidade econômica do lote. (Disoc/Ipea), 2013, p. 82).
\end{abstract}

Porém, além da viabilização dessa produção por métodos de custeio e financiamento, há também a preocupação com a inserção desses produtores no mercado. Aqui cabem referências a dois programas: o Programa de Aquisição de Alimentos (PAA); e o Programa Nacional de Alimentação Escolar (PNAE).

Tanto o PAA, quanto o PNAE são frequentemente acionados pelos produtores como forma de escoar a sua produção. Entretanto, é a partir das obrigações legais previstas na própria legislação que se consegue observar a formação de um tipo de arranjo específico dessa produção.

Criado em 2003, o PAA foi projetado como um dos componentes do plano do Fome Zero a fim de ser um meio de distribuição de renda a partir da dinamização da produção da agricultura familiar. Isso é feito a partir de um mecanismo de aquisição pública, na qual cada produtor tem um documento em que se registra sua condição de participar do programa.

Já o PNAE é um programa existente desde 1955. Porém, é somente a partir da Lei $n^{\circ} 11.947$, de 16 de junho de 2009, que visa melhorar a qualidade da alimentação 
escolar, com produtos produzidos, preferivelmente, o mais próximo possível de onde serão consumidos. Essa legislação prevê que os municípios comprem pelo menos $30 \%$ dos alimentos de produtores da agricultura familiar, a partir de um sistema de preferências aos produtores do próprio município a ser distribuída essa alimentação.

Um ponto em comum entre os programas é que ambos exigem que a participação do produtor neles se realize por meio de uma cooperativa. Assim, tendo um mercado com o qual operar, a organização dos agricultores passaria a experimentar um sentido de ação coletiva na qual eles pudessem, por fim, ganhar recursos de poder por meio desta a fim de conseguir de alguma maneira sobreviver à competição no mercado.

\subsubsection{O Papel da CONAB}

A Companhia Nacional de Abastecimento (CONAB) é o órgão governamental que opera os programas. Porém, haveria um gargalo operacional do programa caso fosse feito diretamente com os produtores, não havendo, portanto, a possibilidade de gerir milhões de contratos de fornecedores da Agricultura Familiar a nível nacional.

É exatamente nesse ponto que a organização dos próprios produtores tem importância. Não havendo a atuação direta do programa a cada produtor individualmente, exige-se uma estância mediadora do ato da comercialização, que é representada pela associação de produtores, seja por meio de uma cooperativa, seja por meio de uma associação propriamente dita.

Entrevistado: O que são esses [problemas] do processo operacional. O que são as falhas pra gente chegar aí no ponto de vista da cooperativa que é a pergunta [a respeito de se haveriam falhas no processo operacional de aquisição de alimentos via $\mathrm{CONAB]}$ e aí as distorções que vão acontecendo do ponto de vista da própria ação, do controle social e do entendimento das duas partes... é... Aí assim, o impacto que esse programa trouxe do ponto de vista da segurança alimentar, de melhorar e de realmente acabar com a fome. Aí só um parêntese, mas complementando a conversa que a gente tinha feito antes da gravação. Antes de instalar o campus aqui, a gente fez a pesquisa justamente com vários segmentos dos beneficiários do Bolsa Família e pessoas que recebiam seus alimentos. A gente conversava com pessoas.... Eu tive a oportunidade de conversar de acompanhar os alunos que vieram fazer entrevista. Porque a gente foi levar num... Como a gente conhecia os locais, tudo né? Os beneficiários são pessoas, tem no depoimento, assim [relataram] o que isso significava para elas realmente. De pessoas que estavam desempregadas, que realmente precisavam daquela comida e [dizem esses 
beneficiários] 'ó, isso me faz a diferença se eu não tivesse isso eu tava passando fome realmente'... Quando o processo é bem feito. A assistência social organiza e chama não só pra entidades, mas pra quem vai entregar, então realmente o impacto é muito positivo e é muito importante. Mas aí tem a questão da operacionalização, porque aí justamente precisava ter uma entidade que ... e aí vem a questão institucional né? dos dois lados. Uma entidade recebedora que organiza e faça a seleção e entregue os produtos pra quem realmente precisa dessa comida, dessa alimentação, onde que as entidades assistenciais, normalmente, às vezes era um Centro Espírita, ou associações evangélicas que realmente trabalham com esse lado público. Mas também tem a manipulação política da mercadoria da fome, que eu percebi isso também. Que muita gente se aproveita da fragilidade da pessoa que 'ah, vou pegar' e ele [esse agente aproveitador] passa a ser aquele mediador que quer começar a manipular essa dependência pra manipular isso a seu favor politicamente. Do lado do consumidor, uma das coisas que a gente percebeu é que o que acaba acontecendo é que a política nunca sempre é perfeita [ou sempre é imperfeita] e que precisaria de ir se aperfeiçoando, com o controle social sobre todo esse processo. Do outro lado, na ponta da cooperativa que é o que organiza os habitantes agricultores que é pra poder ter onde pegar os produtos e entregar. Daí vem essa questão que você tá colocando [do problema processual] que é um ponto importante. Porque isso ajudou, de certa forma, como é um recurso garantido, orçamentário, você faz um projeto e ele fica creditado na conta [da CONAB] ser indo liberado conforme da entrega, e atestado da entrega e recebimento do produto, isso deu uma segurança pro agricultor de que realmente ele vai vender um produto, e vai receber por aquele produto e por um preço razoável até, a questão de depreciação do mercado. Quer dizer, realmente é uma segurança. [interpretando o agricultor] 'Porque eu tô cansado de vender produto e às vezes, levo um monte de calote, ninguém.. e quando... e quando eu produzo e não tem ninguém pra comprar'. Então nesse sentido leva um lado positivo porque isso forçou, de certa forma, que se realmente tivesse uma garantia. E isso permitiu também que a organização da cooperativa, que não tinha uma motivação [para existir] que ela achasse um caminho de mediação. E aí, num caminho também que é uma distorção que é o caminho da dependência. Porque se o agricultor que está entregando, ele não... não foi feito essa discussão, essa formação porque que a política [da compra pública] foi feita. Como é que foi feita, como é que entra nisso.... Então ele entra simplesmente pelo lado econômico. Eu acho que esse é um papel da cooperativa ter esclarecido isso. Nem todo lugar isso foi feito. De dizer 'ó, a política é assim'. Foi formulada por isso, essa situação e foi colocada lá, tal. E ela acabou sendo uma oportunidade para a cooperativa, também da cooperativa sobreviver economicamente e aí vem o dilema e aí a questão que gera conflito nessa relação. Uma que não gera questionamento porque não tem como questionar, se não tem a cooperativa pra intermediar, o projeto e a contratação junto com a CONAB, quem que vai fazer? Não tem pra onde ir. Apesar de querer participar [do programa de aquisição de alimentos]. Não tem opção, então a cooperativa acaba sendo esse elo mediador aí, mas cria esse caminho da dependência. E aí acaba que essa tabela estabelecida aí que 'não, a cooperativa pra prestar esse serviço vai cobrar 20\%'. E esses $20 \%$ não dá margem pra quem participa dizer 'ó, realmente, $20 \%$ de 10 reais é uma coisa, 20\% de 10000 [reais] é outra coisa'. Então qual é o justo? Esse debate ele ficou mascarado, porque claro que a cooperativa pra operacionalizar isso tem custos. Tem contador, quem que vai controlar, tem a despesa do transporte, de pegar o produto na sede do produtor e levar pra lá [para a entrega] Então, é isso que deveria ser mais transparente.... Virou regra geral o $20 \% \%$. 
A cooperativa acaba sendo esse elo mediador com a CONAB, mas acaba criando esse caminho da dependência. A taxa dos $20 \%$, por ser coberta pela decisão em assembleia, acaba restringindo o debate a respeito das manobras possíveis, para a cooperativa diferenciar seus serviços. Diversos relatos das críticas, de assentados assim como de outros agricultores na região, vêm nesse sentido. Ao se taxar os $20 \%$ pela organização da cooperativa, exerce-se a sua instituição. Interpelado sobre sua experiência a respeito desse tema, um dos agentes no assentamento responde:

\footnotetext{
Entrevistado: A gente não tem influência. Quer dizer, as pessoas foram traumatizadas, né? E o Estado, na época ele dava um incentivo grande pra quem tivesse em associação, pra quem tivesse em coisa que fosse sair pra essas famílias teria que ser... Entendeu? Se não tivesse a cooperativa que alguma associação, não tivesse na cooperativa, o próprio Estado forçava a barra. Tem coisa que é da natureza da pessoa... é... livre vontade... se tá bom pra mim eu vou se não tá eu saio. Quer dizer... e daí... Hoje você vai na área 2 , ainda tem um pouquinho de rixa entre a associação e a cooperativa. Porque o cara fala "não, mas eu entrego lá [na associação] e eu pago 50 centavos por caixa. Na cooperativa queriam cobrar 10\%". Então, quer dizer, já parecia um dízimo, sabe? Parecia aquela coisa... o CNPJ parece que cresceu, né? E... Só que daí esse pessoal [fala] 'não, mas eu queria daquele esqueminha lá que eu, se eu produzo e eu levo 10 caixas, 50 centavos cada caixa. Dá 5 reais, né?' Então, a associação, não me faz falta e eu ajudo a associação, pra viagem pra associação, pra telefone, pra qualquer coisa. Então, tá bom pra mim.
}

O sentido do reconhecimento das associações e cooperativas por parte da CONAB para a operação do programa tem uma racionalidade dada. O objetivo é conseguir gerir uma ampla gama de contratos, mas reduzir os custos de transação da manutenção do programa, a partir da delegação de seu controle e atividade gerencial às cooperativas, reconhecidas a partir da assunção de que estas são organizações autogeridas representantes das comunidades locais.

Relata-se por diversas pessoas no assentamento problemas da operação com do programa. Na avaliação de um dos atores no espaço do assentamento, a exigência e o rigor da prestação de contas se trata de um obstáculo para ambas partes, famílias e gestores das cooperativas. Segundo ele, os assentados em geral não têm formação, no sentido de sua instrução formal, para manter a gestão dessas operações burocráticas da atividade da cooperativa. 


\title{
5.8.2.2 Atrasos nos pagamentos às famílias
}

Não se pode deixar de mencionar a intervenção em nível nacional a partir do Plano de Recuperação de Assentamentos (PRA). Este consiste em desenvolver e recuperar as atividades produtivas existentes em assentamentos. Uma das suas consequências foi a aproximação do INCRA do Estado de São Paulo ao MST do assentamento. Assim, se expressa no relatório:

\begin{abstract}
A atuação do Incra ocorre em parceria decisiva com a organização social dos assentados - no PA Pirituba II, o MST é o parceiro fundamental. Esta atuação conjunta possibilita ao Estado exercer função catalisadora que, como consequência, leva ao envolvimento de outros atores sociais, como é o caso das prefeituras locais, universidades e organizações da sociedade civil. Contudo, é importante afirmar que a ação catalisadora, por si só, é insuficiente. A própria experiência no Pirituba II assim o demonstra. (Disoc/Ipea, 2013, p. 86).
\end{abstract}

\subsection{INTERMEDIÁRIOS}

O sujeito social intermediário é, em termos comerciais agrícolas, o mais conhecido e comum a todos os assentados. A princípio, teoricamente, apenas em locais muito remotos ou onde não haja produção relevante esse agente social não estaria presente.

O que caracteriza a sua atuação é a sua impessoalidade, a dinâmica de sua atuação, a efemeridade da sua relação com os produtores, além da percepção por parte dos assentados de seu papel enquanto agente comercial. Além da questão da casualidade de sua atuação, ele também representa uma sinalização prévia da demanda da produção dos assentados.

Assim, o intermediário passa a oferecer uma oportunidade dupla aos assentados, tanto de negociação, na medida em que estes avaliem que suas condições são vantajosas, como de coleta de informações de mercado por parte dos assentados.

Entrevistado: A ideia nossa, até de incentivo, era escapar do intermediário. Sempre foi nosso sonho. Hoje, a gente já tem uma visão diferente. É... Vamos comparar assim, a agricultura orgânica... vamos comparar aí, cerveja semálcool.... Quer dizer, como é que você sai do domínio [das empresas do setor, 
intermediários e do agronegócio]... Se você não toma mais cerveja com álcool, as empresas foram lá e fizeram uma sem álcool! E continuam vendendo, né? Quer dizer, tão vendendo a cerveja? Tão e mais caro que a outra! Então você tá pagando por você ser diferente, né? É... o orgânico, não o orgânico tem lá, se você tá certificado, se tá lá tem um empresa lá, um Pãode-açúcar [rede de supermercados] que compra o seu produto. Quer dizer, é... mas que produto que eles compram? Mas vamos comprar de um grupo organizado. É de pequeno agricultor? Ah... é muito difícil... Aí já dá trabalho, envolve muita gente... Vamos comprar de uma empresa que produza orgânicos, né? Essa empresa... [é de] grande capital, consegue estrutura de irrigação, ambiente protegido, pra não usar veneno, pros insetos nem entrar dentro e consegue sobreviver. Então, quer dizer: aonde que você vai conseguir como agricultor, do jeito que tá a situação do pessoal aí, sobreviver num mercado desses? Como é que você vai conseguir pegar seu produto... a gente tinha aqui um assentado que ele tinha 5 alqueires de banana orgânica certificada. Quando eles tavam discutindo a comercialização, os caras não conseguiam nem desenvolver um método pra diferenciar a banana dele. E daí ele tava vendo que a banana dele era inferior, porque, lógico, ela não fica [bonita]... não tem adubo, não tem nada... Fica uma banana mais feinha, assim na aparência e a maioria de que consome, ele não que saber disso aí, ele quer saber de preço! Ele quer aqueles tomates desse tamanho [indicando serem grandes] que podem tar cheio de veneno e adubo, mas se ele tem dinheiro pra comprar um quilo de tomate, ele quer o tomate bonito. Ele não tá preocupado com veneno, adubo...

De qualquer maneira, a visão negativa da dependência ao intermediário persiste, já que obviamente ele é - e é percebido como—o agente que imediatamente captura a renda do produtor. Porém, isso é relativizado pela questão de que é por meio da iniciativa desse agente que se consegue acessar compradores de maior escala. Nesse ponto, o papel desse intermediário é o de propiciar uma oportunidade de mercado, que sem ele com sua iniciativa, os assentados acabam —além de não escoar seus produtos, mesmo se diferenciados- perdendo esses mercados para os grandes produtores empresariais, que negociam diretamente, e sem intermediários, com esses grandes compradores.

\subsection{PACOTES DAS LOJAS}

Por conta da natureza mais e mais individualizada do trabalho agrícola, os assentados passam a procurar alternativas individuais de inserção de sua produção na lógica do mercado, a fim de atender às demandas deste. Contudo, devido à mecanização, a introdução de insumos químicos, além da própria introdução de novas 
tecnologias para a produção, o produtor, como dito anteriormente, tende a essa individualização.

Nesse sentido, procura estabelecer relações de comercialização com os agentes próximos com os quais tenha uma relação de confiança. Assim, o que se vê nessa busca é o fenômeno do atendimento por pacotes de lojistas da região.

Por causa da dificuldade de acesso a crédito para a produção, assim como períodos de descapitalização dos produtores no período de entressafras posteriores às baixas da produção, há assentados que veem a aceitação desses pacotes como uma alternativa. Atualmente, é o meio mais difundido entre eles para o custeio de sua produção, ainda que não se possa dimensionar isso, pois não foi possível gerar dados a esse respeito. Um dos agentes no assentamento relata o início da formação desse arranjo comercial:

\begin{abstract}
Entrevistado: O pessoal, a maioria, por causa desses endividamentos das associações antigas tal, ficaram com o nome que foi lá pro tal do CADIN [Cadastro Informativo dos Créditos não Quitados de Órgãos e Entidades Estaduais]. Então, o cara ficou sem crédito. O que que as empresas fizeram? "Bom, a gente precisa vender, mas como é que a gente vai vender se o cara tá com o nome sujo?" O quê que as empresas montaram? Um tal de pacotão. $\mathrm{O}$ quê que é esse pacotão? Logicamente, não é aberto pra todo mundo assim, mas o pessoal conhece os produtores tal, e falam "olha, te cedo a semente, te cedo o adubo, te cedo os defensivos e, no final, você vai assinar uma CPR [Cédula de Produto Rural] pra mim que você tá devendo tantos sacos de produção". Não envolve dinheiro de entrada e não envolve dinheiro do retorno, envolve produção. Então, você me deve 1000 sacos de soja. Eu vou te financiar, dar todos os produtos pra você. Inclusive, vendo muita coisa aí que o pessoal do Estado vem "mas não pode arrendar". Mas ele não tá arrendando! Né? O quê que é arrendamento? Arrendamento é eu chegar pra você pegar o dinheiro e você plantar minha área, né? Mas eu tô plantando na área, só que o meu jeito de financiar foi esse. Foi pegar esse pacotão aí e te devolver em produção, pra empresa. A empresa tá vendendo a mesma coisa. Ela, com certeza, ela tem uma estrutura de secar esses grãos e vender por um preço melhor. Quer dizer: ele tá ganhando duas vezes. Ganha na produção que ele vai vender, e mais o trabalho que eles vão ter secar lá. E como é empresa grande, eles têm mais... eles podem pegar por um preço melhor. Podem armazenar pra segurar preço. Pra eles tudo bem. Não é o cara tá com nome sujo que vai segurar ele de produzir. E não vai ser também que vai tirar da empresa de vender.
\end{abstract}

Lojas de veneno, implementos e outros insumos agrícolas, em geral, oferecem pacotes que consistem em prover os assentados de sementes, adubo, venenos, implementos e, não raro, assistência técnica e serviços de extensão rural. Em troca, 
pedem um volume ou uma parte da produção em espécie, descontando o valor do custeio da produção na safra.

Não se relatou outra produção que não a de commodities. Alguns pacotes incluem o próprio oferecimento do seguro ao produtor, algo que o incentiva ainda mais a tomar o risco de tal negociação.

Ainda que na cadeia de comercialização agrícola, se possa dizer que o provedor do pacote esteja numa posição de dominância na negociação, há a percepção de sua participação como auxiliadora, ou facilitadora da produção dos próprios assentados.

Figura 14 - Estruturas de reciprocidade pela interação bilateral. Assentado-lojista, reciprocidade centralizada, lojistas no centro e assentados ao seu redor
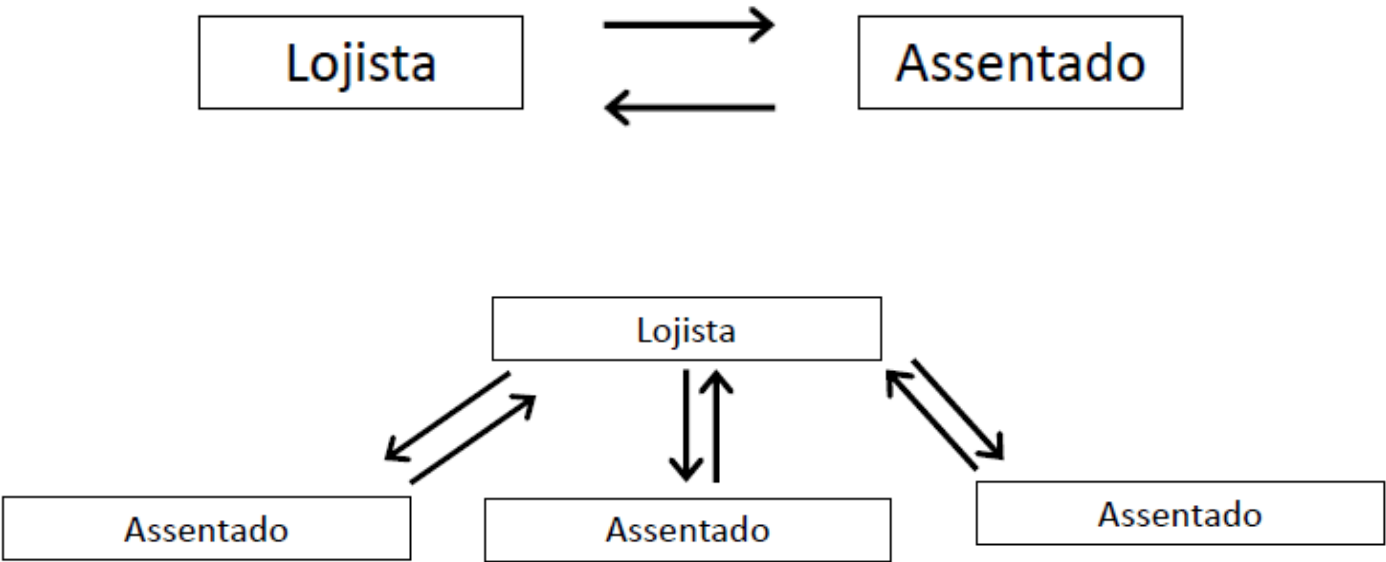

De acordo com os elementos da teoria de Ostrom, assim como para Sabourin, o que se estabelece aqui entre os assentados e os produtores, além da relação de confiança é uma relação de reciprocidade que se dá pela compreensão de que há o elemento reverso da dotação de um a outro. Em outras palavras, a percepção dos assentados individuais quanto ao papel do lojista provedor é de um comprometimento recíproco.

Essa compreensão não é contemplada pelos membros de cooperativas que, ao buscar defender a posição de barganha dos produtores diante da negociação da 
transação fundamental, no caso a da produção por moeda, acabam por refutar o ingresso de recursos externos, assim como de bens de capital. Complementa-se, assim, a proposição da agroecologia como forma alternativa a esse vínculo comercial estabelecido com o lojista.

Diante de cenário e da relação de trocas que se coloca a esses agentes, a própria limitação de recursos disponíveis em posse do lojista pode levá-lo a uma posição geradora de competição entre os assentados, no sentido de preterir um em relação aos demais. Com isso, a relação entre o lojista e seus clientes passa por uma concepção clara de reciprocidade que ultrapassa a uma relação econômica impessoal.

Essa relação comercial se estende a consumos de outra natureza, não apenas ao fornecimento de insumos. O que se passa é que os fornecedores de insumos agrícolas também se beneficiam pelo estabelecimento desses vínculos de confiança e da percepção da reversibilidade da relação. Um relato desse tipo de ação que abarcavam uma ação coletiva é descrito aqui nesse relato:

\begin{abstract}
Entrevistada 1: Nós foi assim. Que nem eu falei pra você. A associação foi montada, aí um fiado foi a do Zé Carlos. Até hoje. Até hoje, faz trinta e ... quatro... três... faz trinta e três anos que a gente compra do Zé Carlos, com dinheiro, com fiado, com dinheiro e fiado entendeu? [...]

Entrevistada 2: Meu sobrinho estava muito doente..... Então o povo tem muita confiança, inclusive porque ele é espírita...engenheiro saiu nos... nos bancos pra fazer financiamento da turma e nos mercados pra ver quem que vendia fiado pra nós porque ninguém tinha crédito, porque tava novo e nas farmácias. Daí o mercado que abriu a porta pra nós foi o do Luisinho Durotide 16 ... e a farmácia que vendeu para nós lá ...
\end{abstract}

Essa relação do lojista com seu estabelecimento fixo na comunidade tem outras consequências dessa mesma natureza de confiança, pois, por vezes, é tratado como um membro da própria comunidade. A princípio, ao propor uma forma de negociação na qual o lojista se apropria de parte do resíduo da produção dos assentados, ele teria a mesma posição na cadeia comercial da relação entre produção e consumo.

Contudo, o que o difere de fato, e não somente através da percepção dos assentados, é que ele auxilia o produtor tanto antes da realização da produção, ao conceder, crédito, insumos e assistência, como depois dessa realização, com a

${ }^{16}$ Esse sobrenome pode não ter sido identificado ou escrito corretamente, pois não houve possibilidade de averiguação de sua grafia correta na entrevista. 
armazenagem ou transporte, a depender do lojista. A relação do lojista acaba extrapolando novamente essa condição de um comerciante, mas em associado dada a relação de confiança que aí se estabelece.

Essa receptividade diante do lojista fornecedor, ou provedor, ao ser tratado de maneira a ser um interno à comunidade, contrasta com o tratamento dado aos representantes da própria cooperativa, que são tratados como "eles, lá da cooperativa", sublinhando a ideia de alteridade presente nessa relação social.

Esse fenômeno antropológico de alteridade entre o associado da cooperativa e a direção da cooperativa pode ser mais bem examinado no estudo de Silvia Maria Pereira de Araújo (1982), sobre a ideologia da participação em organizações cooperativas nas quais fatores de outra natureza acabam conformando a autoridade e o comando técnicocientífico da administração sobre os agricultores. Araújo considera que a cooperativa, enquanto uma proposição de organização no campo, é uma possibilidade de integração de diversas classes sociais no campo, a fim de uma conformação de interesses ao nível da análise da empresa.

Araújo concentra-se na ideia de que há uma apresentação de uma ideologia democrática de autogestão que implica um acobertamento de contradições de classe que se expressam nessa disputa. Assim, para ela, o jogo político que se dá entre os associados pode ser assim descrito:

\footnotetext{
Em qualquer agrupamento social, o fenômeno participativo está muito em função da maneira como se articulam os grupos dentro da associação e, mais além, como os diferentes grupos e/ou categorias sociais se combinam e são vistos no sistema global. Daí a necessidade de se fazer menção à participação social. Assim como o conceito de cooperação, o de participação é um conceito de referência, constantemente encontrado na literatura sobre cooperativismo, o que não o faz mais preciso, nem chega a explicar os fenômenos de agregação de caráter econômico, principalmente. A ambiguidade existente no plano conceitual encobre problemas teóricos e práticos, diante da solicitação que continuamente vem sendo feita à participação social (Araújo, 1982, p. 130-131).
}

Por vezes, são os complexos processos das instâncias de decisão da própria organização cooperativa, com suas normas e regras internas, que acabam por gerar essa alteridade, independentemente da relação que se estabeleça com uma organização rival que venha a prover os cooperados dos mesmos serviços. Por isso, o arranjo do pacote da 
lojista acaba sendo tão disseminado e popular, em contraposição às próprias cooperativas e, em alguma medida, também acaba provendo-as ocasionalmente.

\subsection{DOS PROCESSOS DE REMUNERAÇÃO, OU DE DISTRIBUIÇÃO DOS RESULTADOS, DOS ASSENTADOS A PARTIR DE SUAS RESPECTIVAS COOPERATIVAS}

Após a realização da produção, sua coleta e sua posterior comercialização e entrega, retoma-se à operação de pagamento ou remuneração dos membros da cooperativa de acordo com a alocação de seus determinados direitos. Assim, na observação sobre como se dava a operação de remuneração dos seus membros, encontrou-se um padrão que tem pequenas alterações de acordo com a característica da atividade da cooperativa.

Tal padrão consiste em um pagamento ou remuneração posterior feito pela cooperativa após ela cumprir a operação da transação em que ocorre a troca da produção por moeda. Nesse caso observa-se que a forma como essa transação ocorre é um elemento que determina os arranjos possíveis para esse tipo de pagamento.

Esse é mais um momento em que não há uma possibilidade única ou clara para que haja uma participação, ou voz, dos membros das cooperativas nessa decisão. O ingresso da moeda da transação é uma contingência de mercado, não sendo possível escolher exatamente quem será seu interlocutor comercial.

Dessa maneira, sendo a administração da cooperativa que toma a sua representação na negociação, o que acaba havendo, portanto, é um fenômeno de heterogestão. Sendo assim, o ônus da negociação sobre a operação em que haverá essa remuneração recai sobre os representantes da cooperativa.

Nesse sentido, o que se consegue observar é que a relação de confiança da cooperativa que realiza a reversibilidade da troca, enquanto uma ação que propicie a reciprocidade, tem na operação da distribuição dos resultados um ponto sensível. Isso fica claro pelo fato de os assentados exporem elementos desses problemas operacionais quando em conversas informais a esse respeito, como coletado neste trabalho. 


\subsection{A EXPERIÊNCIA E A VIDA DOS ASSENTADOS}

Analisa-se os impactos da política pública da reforma agrária no assentamento Pirituba II com base nas características discursivas dos assentados, sua instrução e formação política, influência do termo camponês e, finalmente, as experiências associativas.

\subsubsection{Características Discursivas}

$\mathrm{Na}$ análise dos discursos das narrativas dos assentados a respeito de sua própria trajetória e de regularização no assentamento, pode-se observar que, ao interpretar esse processo, os assentados não têm a clara compreensão do papel do mediador dos órgãos

públicos nessa relação. Assim, muitas vezes os assentados acabam sendo manipulados por eventuais ações de representantes do poder público, que nada tem a ver com uma política projetada a partir das esferas superiores da administração pública, como gabinetes formados por lideranças políticas eleitas, ou direções de corpos burocráticos responsáveis por ações governamentais.

\subsubsection{Da Instrução e da Formação Política}

De acordo com os dados levantados pelos questionários com os responsáveis pela gestão dos lotes, cerca de metade da população dos assentados, 49\%, tem ou apenas o Ensino Fundamental completo, ou o Ensino Médio incompleto. Pode-se afirmar que o gargalo ao ingresso em uma universidade, observado para a qualificação em um ensino superior que dê mobilidade profissional, e social, aos assentados está nesta interrupção ou limite de sua formação (Figura 15). 
Figura 15 - Instrução dos assentados

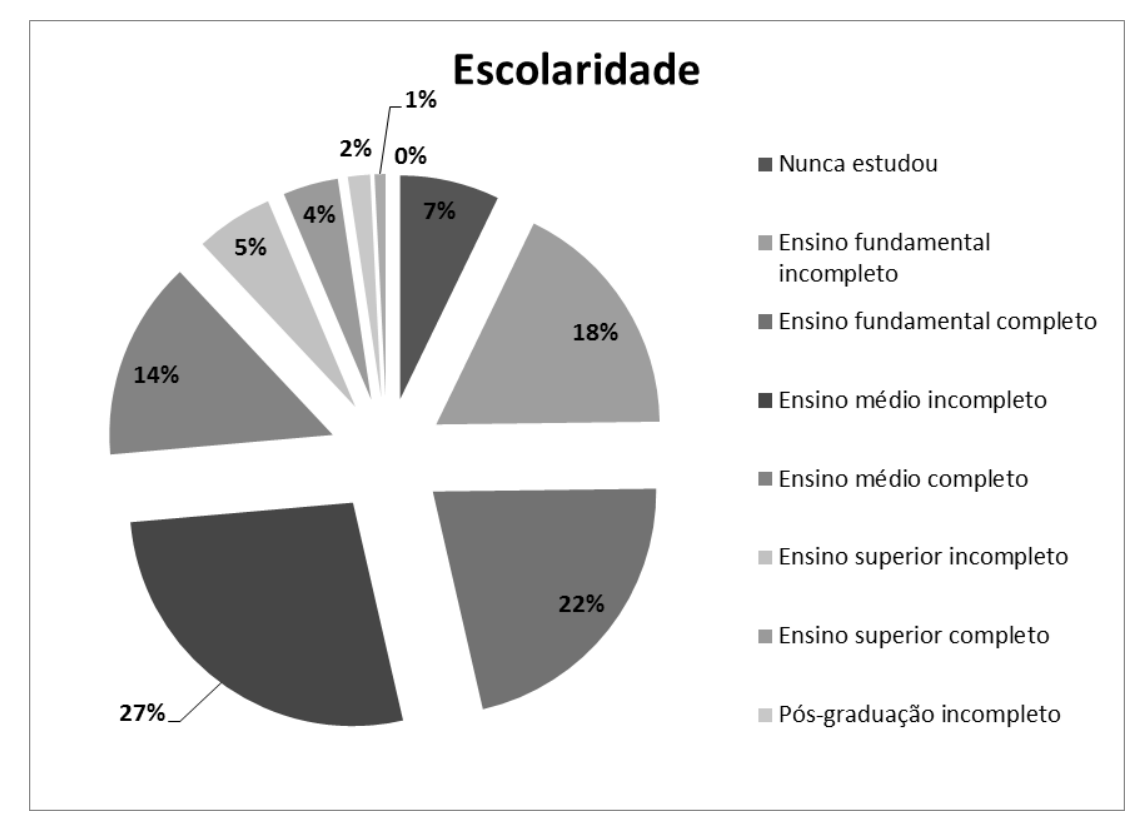

Nota-se que o nível de instrução formal dos assentados é, assim como o da maioria da população, baixo. Entretanto, observa-se uma intensa atividade de formação política nas suas dependências, com a instalação de uma biblioteca e reuniões periódicas.

Pode-se constatar que as lideranças que viveram a experiência coletiva de produção acabaram passando por um processo de formação política. Isso pode ser verificado pelo uso de termos e categorias econômicas do marxismo, expressas em seus discursos, com os quais eles não poderiam se familiarizar sem um processo didático com elementos agentes políticos responsáveis por essa difusão política.

Entrevistado: A cooperativa, ela definiu-se que ia trabalhar de forma coletiva e as ferramentas do trabalho, pra que de fato acontecesse essa cooperação. Foi definido entre o grupo, que a terra, o capital e o trabalho, seriam do coletivo e de forma coletiva. Então, a terra, o capital e o trabalho, juntamos esses três itens fundamental pra acontecer no campo e a partir daí. Então a terra, é de todos, todos os integrantes. 


\subsubsection{O Termo Camponês}

Assim, como o uso dos termos a partir das categorias dos fatores de produção da teoria marxista, pode-se observar o uso do termo camponês. Em alguma medida, podese constatar que há uma relação entre a familiaridade do seu uso e a relação dos que usam o termo a partir da sua relação com o MST e seus movimentos adjacentes.

A produção de um universo simbólico que mantenha a coesão do grupo não se dá dentro dos valores diretamente do movimento. Em alguma medida, o símbolo comum é, por vezes, associado a valores que não estão ligados, ou submetidos ao próprio movimento. Nesse sentido, observa-se um desses usos no relato a seguir:

\footnotetext{
Entrevistado: Sabe quem foi o primeiro camponês? Foi Deus. Ele que plantou um jardim, né? Deus foi o primeiro camponês, que plantou um jardim e depois colocou um homem no meio do jardim e arrumou uma mulher pro homem do jardim. E deu problema, né? [...] Nós nunca vamos deixar de ser camponeses.
}

Quanto mais se é ligado ao movimento, mais se procura retomar o termo que, anteriormente, havia sido suprimido do debate entre os teóricos no Brasil. O que viabiliza a hipótese que confirma essa relação diz respeito ao mesmo papel que se tem com a formação política dos assentados a partir da intervenção do movimento.

Há um esforço em esclarecer uma afirmação social contestatória advinda da concepção de camponês. Já para assentados que são relativamente mais distantes do movimento, ou mesmo fora dele, o que se pode observar é que há uma noção com uma subjetividade expressada na espontaneidade de suas considerações, o que revela o ineditismo do tema.

Dessa maneira, pode-se observar é que a relação entre o uso do termo "camponês" e a condição real dos assentados relativa à dotação de terras e suas habilidades quanto às atividades do trabalho agrícola passa a ser superada. Não há um impedimento técnico em relação à incorporação de elementos de origem urbana no assentamento. Nas palavras de uma entrevistada: "Eu sou urbana, a minha mãe é nordestina e veio da zona rural". 
Nota-se nesse discurso que a condição familiar da geração anterior, ligada ao campo, com a geração nascida e criada na cidade torna possível essa ressocialização em um ambiente doméstico. A partir disso, passa-se então a uma recuperação do modo de vida doméstico.

Porém, considera-se aqui infrutífero, para fins de análise, a discussão em torno da atribuição por parte dos cientistas sociais de que aquela população seja ou não camponesa. Isso se dá pelo fato de que enquanto teoria, a atribuição de que seja um campesinato correspondente ao teórico, como no caso da tradição chayanoviana, ou que esteja de fato correspondendo ao objeto da realidade.

De fato, um debate quanto à essência do sujeito social, no caso como camponês ou citadino - ou operário como em outros estudos-, é despropositado a fins analíticos. Porém, o que se pode observar é que, de acordo com a teoria da economia camponesa de Chayanov, vários princípios, leis e dinâmicas de seu trabalho podem ser verificados em campo e que, à luz dos conhecimentos científicos apresentados por ele e pelos estudiosos da tradição inaugurada por sua obra, podemos empreender um esforço compreensivo dessa realidade. Entretanto, renuncia-se aqui a um aprofundamento sobre serem apropriadas essas atribuições quanto à sua reprodução social e cultural. Um dos relatos aponta para tais características, que podem ser abordadas por estudos focalizados em disciplinas adjacentes a esse estudo em teoria social.

Por fim, retomando a análise de Araújo (1982), toma-se aqui o frequente uso da linguagem reveladora em relação à cooperativa. Araújo expõe que, uma vez criada a consciência da cooperativa como um elemento alheio, resulta-se, então, a alteridade que cinde o sentimento de pertencimento dos seus associados, e explica:

\footnotetext{
A acusação se reveste de roupagem global - 'A cooperativa não funciona'. Concebem-na como uma máquina à parte, alheada para em seguida a imagem ganhar contorno de uma direção responsabilizada pelos acertos e desacertos cometidos. Há um deslocamento e uma identificação, a cooperativa são eles os diretores. É comum no discurso do cooperado a imputação: 'eles: a cooperativa'. (Araújo, 1982, p. 162).
}

O mesmo fenômeno cabe, no nosso caso, além desse, nas imputações tanto a outros órgãos como o ITESP, o INCRA ou a CONAB, como em relação aos movimentos, como no caso do MST. Nesse sentido, essa operação discursiva revela a 
conformação imagética que se faz da relação de sua posição quanto ao usufruto e o acesso às funcionalidades das organizações representadas por essas instituições ${ }^{17}$.

Porém, ao explicar essa relação, Araújo compreende que a relação que se dá entre o produtor e a cooperativa, em termos simbólicos, diz respeito a uma absoluta figura da percepção do próprio associado. Assim a autora exprime essa relação:

\begin{abstract}
O mundo que se manifesta ao produtor-cooperado nesta prática fetichizada não é exatamente o mundo real, mas aquele da aparência das coisas. $\mathrm{O}$ seu conhecimento a nível de senso comum, como forma ideológica do agir cotidiano, projetando-se através das representações na familiaridade das categorias intelectuais que ele manipula, petrifica condições históricas determinadas.

Fato é que a instituição cooperativa reproduz com igual intensidade a estrutura de classes da sociedade onde se insere. Ao mesmo tempo, o seu crescimento, inevitavelmente, transmuda-a em empresa, face às pressões da concorrência. Assim, num segundo momento da história que se acompanhou neste estudo, presencia-se uma cooperativa que se sobrepõe ao associado e, a par disso, assiste-se a várias ocasiões a um discurso justificador dos novos encargos, na tentativa de transferir o mérito para o corpo de associados. A preocupação inicial, ainda romântica com a situação do lavrador, substituiuse pela preocupação com a imagem da instituição. E esta, cada vez mais identificada com ELES: A COOPERATIVA. (Araújo, 1982, p. 169).
\end{abstract}

Com isso, podemos afirmar aqui que é a percepção do associado sobre uma realidade aparente, e não necessariamente um claro conhecimento das informações a partir de um exercício intelectual e racional simplesmente, que condiciona a sua relação com a cooperativa. Nesse ponto, a reputação acerca da organização acaba sendo um elemento fundamental da adesão do associado às atividades da cooperativa.

\title{
5.12.4 Das Experiências Associativistas (Associações e Cooperativas)
}

Um dos pontos fundamentais é que os relatos sobre a relação das experiências feitas com outras que a precederam em outros lugares varia muito de acordo com o relato de cada assentado, não sendo possível, a partir do seu conjunto, determinar quais

\footnotetext{
${ }^{17}$ Não é o objetivo desse trabalho, ainda que se o considere de suma importância, a relação da conformação das mentalidades e da formação das elites. No caso de uma população assentada, como a estudada neste trabalho, o que se pode considerar é que, enquanto um sujeito social que procura afirmação, ele se coloca diante dessas representações como um subalterno. Vale aqui apontar os estudos sobre tal condição de subalternidade feitos a partir do pensamento e das especulações filosóficas de Antônio Gramsci na configuração das mentalidades dos "subalternos" e dos "populares".
} 
seriam verificadas e quais não. Verifica-se aqui que um limite da memória pessoal enquanto uma informação.

Porém, o que é possível aqui é não observar a veracidade factual histórica dos acontecimentos e das suas relações com as experiências precedentes às quais se atribuem tais fatos, mas sim como são reconstituídos pela memória alguns momentos determinantes para a associação.

É a partir da seguinte fala que um dos assentados descreve o momento da inspiração para que se desse a ideia da associação: “O Zezé ${ }^{18}$ falou: já sei! Olha as formigas" - apontando para a estrada como exemplo de forma de associação.

Nessa apresentação do cenário da estrada e as dificuldades daquele momento, nota-se que a ocupação e o acampamento são de fato um elemento simbólico potencial da ação coletiva, a partir da memória construída, e não pela sua factibilidade histórica, por meio dessa experiência. A ideia é de uma personalidade, em que se cruzam vários relatos, de pessoas e agrovilas distintas, atribuindo a esta mesma pessoa tal papel catalizador.

Ao observarmos as experiências associativas em Pirituba, pode se traçar um padrão comum a todas as agrovilas e suas respectivas trajetórias, condicionado por quatro fatores que aproximam a diferenciação por conta da evolução do seu desenvolvimento, sendo estes os seguintes:

1. Todas as áreas do assentamento Pirituba foram obtidas por meio da ocupação da área, tendo assim passado por uma experiência de resistência social e de perseguição por parte dos interessados opositores. As concessões de lotes por via institucional só se deram depois de garantido o domínio da área para fins de reforma agrária.

2. Não havia um plano claro de como seriam os resultados da implementação do assentamento, assim como não havia instrumentos de controle relativo ao seu desempenho. No caso, o próprio aparato institucional vem posteriormente aos temas já enfrentados.

3. Todas as áreas tiveram algum tipo de mobilização precedente à sua própria formação. Porém, progressivamente, a mobilização tomou traços cada vez mais claros de elementos de uma organização política centralizada, com algum nível de atividade

\footnotetext{
${ }^{18}$ Zezé é um nome fictício.
} 
burocrática.

4. A dotação dos recursos variou de acordo com o momento da concepção do seu módulo rural, que determinou o tamanho dos seus respectivos estabelecimentos, assim como no assentamento de outros assentados.

\subsection{O PADRÃO DAS EXPERIÊNCIAS ASSOCIATIVAS E SEUS MOMENTOS}

A análise das experiências examinadas no assentamento permitiu estabelecer que há um padrão que contém, em cinco diferentes momentos, uma relação entre dinâmicas e resultados. Assim, seguem os momentos:

$1^{\circ}$. Logo após a ação coletiva dos assentados, logo após o seu estabelecimento no lote, deu-se a formação de uma organização de representação econômica dos assentados de cada área. A decisão passava pela caracterização dessa associação, como sendo coletiva, assim como a forma da territorialização para a organização do uso dos espaços conquistados, como a formação das agrovilas, com casas próximas ou separadas, ou com a compreensão dos lotes.

$2^{\circ}$. A partir dos primeiros resultados, houve o problema da apresentação destes aos assentados e de sua ação. Isso se deu em grande medida pelo despreparo dos assentados para as atividades burocráticas, o que tornou inviável a manutenção da adesão dos seus membros à organização.

$3^{\circ}$. Ao conformar diferentes proposições sobre o rumo das atividades, assim

como de sua representação, nota-se que há uma demanda de cada família individualmente. Nesse sentido, não havendo espaço para a conformação das diferenças, dada a concepção coletiva da organização, expõe-se o conflito de interesses e o litígio entre as partes.

$4^{\text {o. }}$ Uma vez declaradas as hostilidades, os demandantes acabam por dissidiar e procurar meios de saída da organização. A questão passa a ser a barganha em torno ao patrimônio que o corresponde nesse momento, impondo-se apenas pela política real, dada uma correlação de forças entre os envolvidos no litígio.

$5^{\circ}$. Logo após a saída desses membros há um rearranjo entre os membros presentes nessa organização. Assim, o que se observa é que há um período de 
verificação tomando em controle a situação dentro da organização e o resultado dos que saíram. Se houve melhora dos que saíram, pode haver um novo conflito e a individualização por completo de todos os membros da organização, ou se não há o conflito direto, entra-se em um momento de apatia até que a organização finda, sem necessariamente ter um episódio que sacramente esse fim.

O que se pode compreender dos relatos dessas experiências é que há questões comuns sobre as quais houve o problema da decisão sobre a ação coletiva. Nesse sentido, observa-se aqui que os problemas vividos envolviam basicamente questões das seguintes naturezas:

- divisão e regime de trabalho (permissão ou requerimento de outros familiares para somar ou entrando como sócio) - a questão era de que o modelo de representação favorecia que famílias maiores concentrassem os recursos, ainda discutindo remuneração por diária, por resultado ou por pessoa

- inscrição dos membros e de seus respectivos direitos de decisão e de apropriação dos rendimentos

- repartição dos resíduos (resultados ou dividendos)

- regime do uso de bens comuns

- os projetos e a participação dos membros neles.

Sobre as experiências associativas, o que se nota pelos assentados é a de que há a preocupação com o acesso a bens públicos, à concessão ou à atribuição recursos, como incentivos que os induzem à transformação de suas respectivas organizações associativas. Cabe aqui o exemplo relatado a seguir, sobre a diferença entre a condição de um entreposto e a de uma associação, em que há a percepção de que a segunda tem apoio de concessão de bens de produção, auxílio crediário e entre outros benefícios de diferentes naturezas. Como explica uma a Entrevistada 2: “Só que se fosse um entreposto, se fosse pegar um trator da prefeitura não saía. Como [associação] é mais fácil dela [prefeitura] fornecer pra você. Tem a diferença, é nisso". 
No caso da transformação da associação em cooperativa, além de se tornar uma organização com fins lucrativos, ela passa a ter acesso a financiamentos. O Quadro 2, a seguir, mostra características dos arranjos produtivos do Assentamento Pirituba, entre os quais se encontra a Copava.

Na Agrovila 2, a primeira experiência de associação foi entre 1985 e 1987. Ela conseguiu um volume de recursos ainda não vistos pelos assentados, como um barracão, que hoje é do ITESP, e diversos tratores foram em algum momento dessa associação. Porém, ela acabou não conseguindo se sustentar. Corroborando as observações já vistas por Emelianoff a respeito da dificuldade de associações do tipo subsistirem sem a presença do governo em seus espaços:

\begin{abstract}
Chegou a ser tratado como um "assentamento modelo", não só pela rentabilidade alcançada, mas também pela sua forma de organização baseada na associação de produtores, organizados em grupos de produção. Dificuldades com o pagamento das dívidas bancárias contraídas levaram à inadimplência da associação. A perda do maquinário agravou a situação dos produtores, uma vez que mais da metade destes chegou a ficar impossibilitado de obter crédito de custeio. A crise econômica veio acompanhada da implosão da associação. A possibilidade de recuperar três tratores, por desinteresse do credor, permitiu o ressurgimento e a viabilização de grupos de produção. (Carvalho \& Dulley, 1994, p. 22-23).
\end{abstract}

Quanto a isso cabe a orientação de um dos agentes externos no assentamento que relata sua experiência assim: "Nós nos perguntávamos se era isso mesmo. Se era a coletivização ou se era a cooperação". A confusão conceitual relatada está expressa na seguinte fala de um próprio assentado da Copava a respeito da produção coletiva: "O governo sempre criou a individualidade. O próprio Estado, por exemplo, ele não tentou fortalecer essa ideia da cooperação. O Estado sempre individualizou".

Segundo as informações coletadas na estadia em campo, no período entre os anos de 1987 e 2003 não houve experiências associativas agrícolas relevantes na Agrovila 2. A retomada das experiências associativas lá se deu com o lançamento de programas específicos a partir de 2002. Uma das razões para a retomada de experiências dessa natureza na área 2, onde menos se aceitou a coletivização, se dá pelo acesso a programas de incentivo à agricultura familiar que previam a intermediação de uma organização cooperativa para o seu acesso. 
Houve manobras por parte dos integrantes dos movimentos sociais que acabaram por transformar as propostas, no sentido de manipular as proposições, como a referida ao problema da quebra da expectativa entre a convocação e o assunto objeto das reuniões. Fazia-se uma convocação para a discussão de um determinado assunto e, quando os participantes chegavam no local, tratava-se de outro tema, como se observa a seguir:

\begin{abstract}
Entrevistado: As regras da cooperativa eram todas iguais, mas o trabalho que era diferente.... Por exemplo, hoje, nós se reunia no escritório à tarde e falava 'olha, amanhã nós vamos convocar o povo e nós vamos conversar sobre este assunto, né?' Aí tava marcado pra conversar sobre aquele assunto. Só que quando chegava na hora da reunião eles mudavam o assunto. Cansaram de mudar. E eu acho que não podia. Se tava decidido entre a diretoria que ia conversar sobre determinado assunto, tinha que ser aquele assunto, né? Não poderia mudar. Só que quando eles chegavam nos escritório pra fazer a... aí já pulava o tema e ia pra outras conversas que não tinha nada a ver.
\end{abstract}

Pode-se depreender desse relato que as reuniões pareciam ser de pouca utilidade, já que demandavam tempo e que nelas não havia uma evolução. Nesse ponto, o que se pode conceber também é a não compreensão da instância de foro da ação coletiva.

A ideia de que o jogo político se impõe na decisão coletiva, ou seja, de que a reunião teria um determinado assunto e que este acaba sendo extraviado. Ainda que não se possa depreender se o relator tenha compreendido, ou suposto, uma articulação por parte dos assentados participantes de outros movimentos ou organizações 
Quardo 2 - Associações, cooperativas e grupos informais por área no assentamento Pirituba e respectiva forma de organização da produção

\begin{tabular}{|c|c|c|c|}
\hline Nome & $\begin{array}{c}\text { Tipo de Organização } \\
\text { da Produção }\end{array}$ & Área & Período \\
\hline Coprocol & $\begin{array}{c}\text { parcialmente } \\
\text { coletiva e individual }\end{array}$ & 1 & \\
\hline 13 de Maio & $\begin{array}{l}\text { parcialmente } \\
\text { coletiva }\end{array}$ & 1 & \\
\hline Grupo Informal (ex-área) & coletiva & 1 & \\
\hline Copadec & coletiva & 4 & Fim se deu em 2000 \\
\hline Grupo do Alemão & coletiva & 4 & \\
\hline Associação $1^{\circ}$ de Outubro & individual & 4 & \\
\hline Copanossa & coletiva & 5 & $\begin{array}{l}1994 \quad \text { sem fim } \\
\text { definido }\end{array}$ \\
\hline Copava & coletiva & 3 & \\
\hline Copaese & coletiva & 3 & \\
\hline Grupo dos 8 & coletiva & 3 & \\
\hline Cooperativa "Chico Mendes" & coletiva & 6 & \\
\hline Cooplanta & ---- & $\begin{array}{l}5 \text { e depois } \\
\text { todas }\end{array}$ & $\begin{array}{l}\text { Formalizada como tal } \\
\text { em } 2005 \text { - até hoje }\end{array}$ \\
\hline Copafasp & individual & 2 & 2004 - até hoje \\
\hline Apalufer & individual & 2 & 2006 - até hoje \\
\hline Cooperafai & individual & 3 & ?- funciona até hoje \\
\hline
\end{tabular}

Fonte: Elaborado a partir de Dados de Pesquisa e Costa \& Bergamasco, 2003, p. $128^{19}$

O primeiro estudo focalizado no problema da gestão no Assentamento Pirituba II foi o de Yara Carvalho e Ricardo Dulley, que aborda a questão do sentido da reforma agrária e das condições da formação da gestão dos empreendimentos agrícolas no campo.

Carvalho e Dulley fazem, assim, um esforço de compreensão dos efeitos da reforma agrária e aproximam a experiência vivida em Pirituba II, com a da reforma agrária chilena. Os elementos que evidenciam uma possível aproximação são: a questão do projeto de reforma, a dotação de recursos aos assentados e a composição da gestão

${ }^{19}$ A formulação desse quadro geral se deu a partir de dados elaborados em trabalhos precedentes de outros autores citados aqui, cruzando-se informações de diversas naturezas, como relatos, publicações institucionais ou registros das suas atividades. Procurou-se, dentro do possível nesse trabalho, reunir o maior número de informações para a geração de dados confiáveis. A maioria das experiências associativas tem pouca documentação ou registros burocráticos escritos. Algumas das cooperativas entram num estado de apatia geral, sem o fim determinado por uma data. Sobre outras, não se conseguiu precisar a data de seu princípio ou formalização por, infelizmente, não termos contato com os responsáveis diretos por esses trâmites. 
das unidades produtivas, a partir de agregação se derivam as unidades associativas, associações ou cooperativas (Y. M. C. de Carvalho \& Dulley, 1994).

Já naquele momento, esses autores apontaram para uma crescente individualização por parte dos produtores diante do processo de trabalho agrícola, assim como da sua comercialização. Nesse ponto, o que se observa é que essa tendência observada pelos autores à época se ampliou.

Os elementos dessa transformação adquiriram um nível qualitativo, no sentido da incorporação de elementos monetários no processo produtivo e comercial do seu trabalho, da indução transformadora por maneira de produzir entendida dentro do âmbito da ciência agronômica moderna, e, por fim, das inovações da forma de organização social em torno da produção.

É a troca social que se faz visando a obtenção de moeda, com a instituição do dinheiro, que faz com que a necessidade da organização de trabalho conjunto, ou comunitário, como no caso do mutirão (ou puxirão), passe a ser feito por meio de um mercado de aquisição de bens e serviços.

Em outras palavras, por conta da incorporação de meios de produção que se realizam mediante a troca fundamental de moeda por produção, a transação da unidade de análise em economia das organizações constitui a transformação qualitativa da lógica da ação coletiva por parte dos próprios assentados.

Há um ponto importante na configuração dessas agrovilas: a ideia de que não havia uma instituição de cooperação que pudesse sustentar formas precedentes de ajuda mútua ou de trabalho coletivo. Estudos anteriores sobre o caso de Pirituba apontam para a influência positiva do acampamento na capacidade associativa dos assentados.

Dessa maneira, o que se consegue observar é que a proposição inicial geral foi de produção coletiva, ao contrário da Agrovila 2, em que a produção foi individual.

\subsection{A PROPOSTA DE COOPERAÇÃO COLETIVA: DISSIDÊNCIA DA ÁREA 2}

A forma de produção e de moradia foram elementos da "briga dos individuais" no assentamento, tendo sido as questões que enfrentaram grande estranhamento por parte dos recém-estabelecidos. Com a ideia de moradia — apesar da retórica de que seria 
facilitada a provisão de infraestrutura, como luz, água, saneamento e acesso- se procurava, por uma parte de seus propositores, a manutenção de um sistema de controle social dos assentados, tendo em vista que qualquer tentativa de mobilização por parte de dissidentes poderia ser identificada ${ }^{20}$.

É a partir da construção de mecanismos de controle que se acaba conseguindo pressionar os assentados a aderir a uma determinada agenda à época. Os relatos tratam da coerção feita sobre os assentados para que correspondessem à proposta de cooperação dos movimentos, além do que, mesmo depois de sua anuência, havia pressões feitas para retirá-los do lote.

\subsubsection{Primeiras experiências de associativismo: coerção (pressão dos movimentos)}

De um modo geral, os relatos sobre as experiências precedentes expõem que, nas cooperativas de produção coletiva, observou-se o problema da agência na relação entre o quadro administrativo, como gestor, e a coletividade dos membros, como trabalhadores. Isso se dá pela questão do problema da distribuição dos resíduos, ou resultantes, e dos respectivos responsáveis pela atribuição de valor em meio a toda a operação da atividade da cooperativa.

É claro aqui outro elemento geral das experiências associativas que complica o papel da gestão diante da questão de o camponês, enquanto sujeito social, ter uma forma de ação econômica caracteriza pela autoexploração do trabalho, como afirmado pela teoria chayanoviana. Trata-se de um fator complicador ao limitar as formas de intervenção por parte dos gestores na acomodação da atividade desses agentes aos objetivos da organização, já que há uma procura de autonomia na reprodução da economia camponesa.

Dessa maneira, somado o problema da agência à atribuição de autonomia do trabalhador agrícola diante do desafio da cooperação, também podemos identificá-la como o slack na teoria de Hirschman, fenômeno que se dá, seja por vícios processuais, seja por um laxismo dos membros da organização produtora. Ao não poder ser identificado ou atribuído, a teoria hirschmaniana coloca o problema da associação

\footnotetext{
${ }^{20}$ Essa informação foi coletada no assentamento, numa conversa casual no convívio com um dos envolvidos nas decisões desse âmbito; mantém-se o anonimato a fim de preservar o informante de qualquer tipo de constrangimento posterior.
} 
justamente diante da questão da lealdade ou não da manutenção da permanência dos membros (trabalhadores agrícolas) diante da criação ou não de mecanismos para tal.

\subsubsection{A produção do feijão e a venda em São Paulo: a desilusão da associação}

No ano de $1987^{21}$ relatou-se um grande esforço comum para a produção de feijão. Com os primeiros resultados da produção, que superava as experiências prévias dos próprios assentados quanto à cultura do feijão, criou-se um grande clima de otimismo e expectativas, como relata a Entrevistada 1: "Eu fiquei lá 15 dias. Só eu de mulher. Fiquemos 15 dias lá vendendo feijão. Chegava à noite, despejava no apartamento do INCRA. Foi o Zezé que arrumou esse negócio do feijão pra nós. Não tinha pagado conta do mercado, gasolina...".

Outro assentado oferece o seguinte relato sobre o mesmo fato:

Entrevistado 2: Foi a primeira safra que a gente colheu 22000 sacos de feijão aqui. Que foi uma venda histórica, aqui, a primeira. E a segunda safra, também foi uma safra também, histórica. Essa foi vendida em São Paulo.

Entrevistador: O senhor se lembra quantos sacos eram nessa segunda safra?

Entrevistado: A segunda foi 18000 sacos. Isso da área 1 e da área 2. Foi vendido em São Paulo. Foi no tempo do governo Quércia. Foi feito uma negociação aí fi [vocativo: filho] feito os pacotes, o feijão da reforma agrária. Era um pacote de feijão, 2 quilos. E a gente foi vender em São Paulo. A gente vendia em São Paulo ... nas estações de trem [metrô] ..., Mas era muito feijão mesmo. Por sinal, o último dia nosso mesmo. Tinha dois mil sacos de feijão pra vender e anunciou que ia... Quase que a gente foi ralado [linchado, espancado] porque o feijão não era, bom... pro que é São Paulo, dois mil sacos de feijão era pouco.

21 A data atribuída a esse fato aqui não pôde ser precisada por falta de registros e por contrariedade dos relatos. Sabe-se que ocorreu durante o momento do governo da presidência de Sarney e que ainda se vivia a experiência da primeira associação. De acordo com a percepção de um assentado, o volume de dinheiro em espécie era muito maior do que o esperado dado o volume da produção. Abre-se aqui o espaço para a formulação da hipótese de que esse volume pode ter tido o seu valor desconstituído em meio ao típico cenário de hiperinflação à época — sendo que a incompreensão dos mecanismos de reserva de valor em moeda fiduciária nesse contexto posse ter fracassado a empresa dos assentados. Dentre os relatos, considerou-se o mais provável essa data. A esse exemplo, tomo o relato a respeito de um suposto roubo de parte do dinheiro obtido nessa comercialização do feijão. Segundo o relato, parte desse dinheiro foi encontrada há pouco tempo, no forro da casa de um dos responsáveis à época, durante uma obra na moradia feita pelos próprios assentados. Alegou-se que o dinheiro acabara perdido porque "ele não pôs na caixa e não fez nada com o dinheiro" e por isso seu valor acabou perdido. Há a possibilidade de que ele não tenha feito nenhum uso do dinheiro por medo da descoberta de seu roubo, mas que, ao entesourá-lo, acabou perdendo a oportunidade de investir o valor desse montante. Para uma mais rigorosa pesquisa histórica caberia localizar o dinheiro em espécie, o que acabou não sendo possível neste trabalho. 
Entretanto, o volume da produção não correspondia à sua rentabilidade. A partir do que se pôde registrar dessa experiência, não havia um planejamento ou uma proposição de gestão clara. Não se tratou sobre os custos da produção durante o processo produtivo e, com isso, a expectativa se transformou em frustração, decorrendose a partir daí uma apatia.

Há uma indisposição entre os assentados da Agrovila 2 e os demais por conta da sua característica. Na verdade, vê-se que a diferença no desempenho no trabalho de cada um gera animosidade nos demais. Em alguma medida, os assentados que se mantêm num trabalho individual sentem por parte de outros uma não reciprocidade, sendo uma questão relativa à forma do trabalho agrícola pelas diferentes culturas de origem de cada assentado.

A Coprocol foi a primeira experiência de coletivização que teve que vender os maquinários e ativos da cooperativa para pagar as dívidas. Isso se deu porque os assentados tinham acesso a um crédito a juros de mercado, sem a especificidade de um tipo de crédito agrícola.

\subsubsection{A questão da unidade familiar como lógica de ação coletiva}

A ampliação do uso tecnológico na esfera da produção agrícola reduziu a necessidade de mão-de-obra, sobretudo nos estabelecimentos de maior área plantada, o que acarreta uma diminuição também no papel de outros membros da unidade familiar, além do seu chefe.

O ingresso de tecnologia pode ser o elemento causador da transformação da economia camponesa, em sua visão chayanoviana, mas não no sentido imediato de alterar os métodos da produção agrícola. O seu efeito é na relação existente entre a demografia e a demanda e o uso de mão-de-obra na medida em que se forma um mercado para tal no domínio do espaço rural.

A questão dos agregados de unidades, porque essas unidades são organizações sociais familiares, que têm na cooperativa sua representação, demonstra uma lógica que pode se sobressair às disputas por diferenças de compreensão técnica dos problemas, ou por diferenças ideológicas na cooperativa. O que se entende pela observação da 
composição das lideranças e com base nos próprios relatos é a ideia de que a família enquanto organização fonte do poder exerce uma função das chapas.

À medida que se torna evidente a oposição entre uma família e outra na disputa pela gestão das associações, quaisquer que sejam, observa-se um acirramento entre elas. Sendo assim, o que se dá é que a composição da associação e da correspondência das famílias na sua representação.

Esse conflito entre as famílias pode tomar forma a partir de uma decisão sobre a remuneração dos membros da organização, uso dos bens comuns, ou pela disputa por um determinado cargo - ou pode expressar-se de outras maneiras, como no caso da representação das famílias, na composição de uma gestão que coloque os membros de determinadas famílias em posição de uso ou usufruto de recursos de outras unidades de forma exclusiva.

A questão da projeção das formas de apropriação dos bens pela unidade familiar é um elemento fundamental na dinâmica social e política da ação coletiva.

Uma explicação possível para esse processo é que a organização da cooperativa, nesse caso, tornou-se uma só família, seja por ter assistido à saída das demais, ou por ter havido uma incorporação entre os núcleos familiares. Trata-se, de qualquer maneira, de uma forma de apropriação dos espaços pela unidade familiar.

Nesse ponto, a concepção familiar do assentado, ao tomar para si o empreendimento agrícola, também transforma os elementos condicionantes de suas decisões. No caso, observa-se que a alteração da sua condição de mercado, como no caso de ser dotado de terra para o seu próprio empreendimento, acaba transformando a sua condição de classe.

A influência da família na conformação da ação coletiva não é restrita apenas ao processo do trabalho agrícola; estende-se a outras esferas do trabalho, como no caso do engajamento nos movimentos sociais.

Isso se dá como um espaço de sociabilização, tanto para a formação do movimento social, que se dá a partir da transmissão da formação política entre as sucessivas gerações, quanto para a contração de matrimônios, que se dão a partir da especificidade do modo de vida militante, que acaba por condicionar a manutenção dessas relações. 


\subsubsection{Das coalizões nas associações}

A articulação das coalizões dentro das associações se dá nos termos das coalizões camponesas como descrito por Eric Wolf (1976), em Sociedades Camponesas. Trata-se de uma maneira de articulação correspondente à unidade familiar, quando inserida em um contexto de uma unidade social que a contém em um âmbito que extrapola a sua própria condição.

Assim, diante da relação de apropriação dos recursos disponíveis no seu espaço de ocupação, a formação de coalizações camponesas se configura como um elemento comum a uma sociedade ligada à produção agrícola e aos problemas dela oriundos.

O que se pode entender dessa relação é que, havendo ou não uma questão da gestão profissional, dada uma prerrogativa da administração técnico-científica, ou uma questão ideológica pela qual a organização age em favor, a lógica familiar se impõe. A forma como se dá essa imposição é pela articulação dos membros da família para a configuração de um arranjo ou de outro que lhe permita formas de apropriação dos bens de uso comum.

Outro aspecto importante é a representação da cooperativa enquanto "propriedade" da própria família. Nesse sentido, há a ideia de que uma família possa se articular para corresponder a uma organização associativa, a fim de conseguir acesso, por exemplo, a mercados institucionais, linhas de crédito especiais, fomento e custeio à produção.

Do ponto de vista das contradições entre os assentados quanto às decisões nas instâncias da ação coletiva observou-se que há uma articulação feita a partir de uma unidade familiar que se estende por meio dos laços de parentesco. Logo, a formação da organização, pela agregação dessas unidades, se dá em meio a um ambiente cooperativo dentro do domínio doméstico e familiar. 


\section{$5.15 \mathrm{O}$ LABORATÓRIO EXPERIMENTAL E AS PROPOSTAS DO MST (CLODOMIR DOS SANTOS MORAIS)}

O MST é uma das organizações com maior expressão propositiva em relação à indução à cooperação. Isso se dá, não por ser o movimento que funda o assentamento, mas por ser o movimento que melhor captava recursos e detinha maior representatividade social como protagonista na defesa da agenda da reforma agrária. Uma expressão dessas propostas foi a dos Laboratórios Organizacionais de Campo (LOC), idealizados por Clodomir dos Santos de Morais.

Desta forma, o que se pode observar é que inicialmente, o MST protagoniza o projeto dos laboratórios enquanto formulador e propositor de agendas para os assentados. Isso se dá porque era não o movimento formador do assentamento, mas o movimento que angariava maior representatividade e recursos enquanto defensor de uma reforma agrária que originou esses assentamentos. A expressão máxima desse fenômeno se dá com os laboratórios experimentais de Clodomir dos Santos de Moraes, como aprofundaremos mais adiante.

Assim, a formação do assentamento se dá em 1984 durante o governo Montoro, que era anterior à fundação do MST, por meio de um movimento de posseiros dessa região. Este é caso da formação da Agrovila I em que se inaugura o assentamento.

Porém, é a partir de 1996 que se inicia outra onda de expansão por parte dos assentados e dos sem-terra na própria fazenda, aumentando o espaço do assentamento, ocupando toda a área correspondente (Fernandes, 1999). Nesse sentido, pode-se considerar que há momentos distintos no interior do próprio assentamento, um da mobilização anterior à fundação do MST, outro que se dá com a incorporação de áreas da antiga propriedade e que é feita com a capitania do movimento como ente organizador das ações coletivas. Assim, o que se pode compreender é que o movimento passa a se constituir como a organização com primazia e maior capacidade de promoção de interesses e ações nos fóruns de decisão da cooperativa, ou de associações civis. Porém, mudanças podem ocorrer por conta da influência por parte de organizações civis de outras naturezas. 
Contudo, o desafio comum da busca por sobrevivência e da continuidade da ocupação da terra acaba por ser encarado pelos produtores menos dotados de recursos, que são coincidentes os camponeses com pouca terra e assentados, além de sitiantes e produtores que acabam por ter acesso à terra por outros meios. Esse desafio não é recente, e já foi observado por movimentos precedentes ao próprio MST, como no caso das Ligas Camponesas em que Francisco Julião projetava na formação de organizações cooperativas agrícolas como um caminho de emancipação. No extrato a seguir, Julião expõe o espírito dado à cooperativa como uma organização de salvação dos pobres do campo, como se pode perceber na seção intitulada $O$ Caminho é a Cooperativa:

\footnotetext{
$\mathrm{V}$ - A cooperativa

Mostrarei, agora, o terceiro caminho. É a cooperativa. Que é isso? Eu te explico.

Cooperativa quer dizer: um por todos e todos por um. Para que serve? Serve para o

foreiro. Para o posseiro. Para o pequeno proprietário. E para o médio também. Na luta contra o latifúndio. Contra o atravessador. Contra o isolamento. Vou te dar um

exemplo. Em um município há 500 proprietários de 100 quadras de terras para baixo. São os médios proprietários. Há mil proprietários de 20 quadras para baixo. São os pequenos proprietários. Há cinco mil foreiros ou rendeiros. Todos se juntam, os médios e os pequenos proprietários com os foreiros. E fundam uma cooperativa. Há uma lei mostrando como se faz. Com a cooperativa tu te defendes do latifúndio, que vive com o olho no teu pedaço de terra, na tua bola de algodão, de arroz, de banana ou de café.

Como sócio da cooperativa, tu pagas uma mensalidade que a tua bolsa não sente. E

isso serve para muita coisa. Para te libertares das garras do agiota, que te empresta

100 por 200. Do atravessador, que compra o teu produto pelo preço que bem quer e finda enriquecendo com o teu suor. A cooperativa pode comprar o caminhão para levar o teu produto à cidade, cobrando frete barato. E te fornecer os instrumentos agrários, o adubo, a semente, o inseticida, por um preço que tu nunca encontrarás no mercado. A cooperativa terá o agrônomo para te ensinar como a terra produz mais. E o médico para te curar. E o advogado para te defender. E o professor para educar os teus filhos. A cooperativa acaba com o teu isolamento e te oferece uma vida nova. A cooperativa é a união. Todos por um e um por todos. E a união, digo e repito, é a mão da liberdade. A cooperativa é, portanto, um bom caminho. (Stedile, 2011, p. 202).
}

É neste sentido, portanto, que se observa que os cadernos de formação política do MST (especificamente, os cadernos V e XI) são fundamentais para a compreensão do papel da cooperativa nos projetos de reforma agrária do MST e dos movimentos decorrentes. Nesse caso, a visão de cooperação que persiste é daquela dada por uma 
valoração socialista, em que se procura eliminar o caráter exploratório da interação econômica, seja pela instituição da propriedade, seja pela intermediação comercial dada por uma estrutura de mercado oligopsonista no nível local. Essa perspectiva da cooperação acaba por se diferenciar das concepções associativistas em que, de alguma maneira, há uma tentativa de fortalecimento dos próprios agentes na atuação do mercado, tendo um caráter bidimensional, proprietários e trabalhadores. Com isso, o papel da cooperativa parece ser aquele no qual se a observa como sendo uma organização de classes, sem uma perspectiva estratégica a partir de recursos de mercado, mas sim como a conflagração política como anteriores às diferenciações de mercado.

A experiência dos Laboratórios Organizacionais de Campo, idealizados por Clodomir dos Santos de Morais, em Pirituba, é exemplar quanto ao caráter da intervenção agrária nesse sentido. Consistia basicamente em formar grupos de produtores, estabelecendo para tais um determinado prazo em que ao seu final, deveria se constituir uma organização cooperativa de produção, coletiva e centralizada, dada uma hierarquização da organização semelhante às concepções marxista-leninistas de organização do partido.

Nesse sentido, violavam-se os princípios de autonomia da organização do trabalho no campo por conta da necessidade da mudança revolucionária em um determinado foco espacial de luta. Além de se considerar a necessidade de autonomia como um desvio, de inspiração burguesa, como no caso das proposições anarquistas, também se criticava o próprio marxismo dadas as concepções do espontaneismo como tendências contrarrevolucionarias, ou vícios. A esse respeito Clodomir expressa no Caderno de Formação 11, Elementos sobre a Teoria da Organização no Campo:

O espontaneista é resistente ao planejamento dos trabalhos ou de ações e muito menos age conforme um plano de trabalho. [...]. Sabendo que os trabalhos planejados não lhe deixa espaço para dedicar-se a seus assuntos ou ao que mais lhe agrada em detrimento dos interesses da empresa, o espontaneista começa logo a tachar de burocratismo à ação planejada. Quase sempre vomita frases como estas: "necessitamos de mais ações e de menos planos de organização; aquele que muito planeja e muito organiza, nada realiza".

E segue: 


\begin{abstract}
$\mathrm{O}$ anarquista reage à organização das coisas ou das ações. Não controla nem contabiliza os recursos. Dirige uma empresa como se dirigisse uma bodega: dinheiro entra, dinheiro sai e ele não anota nada. $O$ anarquista se irrita quando vê as coisas muito organizadas. [...]. Desorganizar para reinar, enquanto reina, o anarquista salva seus interesses pessoais, deixando para trás os interesses da empresa. Por isso ele nunca reclama quando vê as coisas desorganizadas pois é da desorganização, da confusão, que o indivíduo anarquista consegue satisfazer seus interesses pessoais (Morais, 1986, p. 3031).
\end{abstract}

Com isso, a finalidade da cooperativa como organização de classe e, não com a perspectiva estratégica para inserção no mercado, tinha como objetivo a formulação de um programa, e sua implementação por meio dessa organização, uma evolução da consciência e da formação política dos seus membros. Com isso, do ponto de vista da estrutura da organização da cooperativa há uma caracterização na qual o quadro dirigente político, é simultaneamente capaz de impor uma determinada decisão aos agentes econômicos.

Apesar da primazia política da sua formulação da cooperação agrícola, Clodomir não ignorava a inserção econômica desses camponeses no mercado. Na verdade, essa era a orientação que se dava, pois para ele os pequenos produtores camponeses, ao se voltarem para uma produção de mercado, acabavam por se tornar vulneráveis nas suas relações com ele e, assim, entrariam em um caminho de endividamento sem volta na dependência de créditos e insumos do mercado e que ao final, perderiam suas terras por conta da sua incapacidade de honrar esses compromissos financeiros.

O Laboratório Experimental se tratou, então, de uma estratégia de capacitação massiva de pessoas habilitando-as à administração da cooperativa, mas que previa um efeito multiplicador na replicação desse experimento pelo qual passara que, assim, simultaneamente, elevasse seu nível de consciência. Essa mudança de consciência, do sujeito que a vive e da função da organização é que, ao final, você teria uma cooperativa. Assim, a compreensão da cooperação como expressão da vontade fica mais uma vez clara aqui.

Nesse sentido, novamente se observa uma concepção equivocada do que seria uma organização cooperativa. A suposição de que a cooperativa seria um tipo de organização mais complexa não corresponde ao que também se supõe como sendo uma organização superior. 
Ele formou vários agentes multiplicadores dessa metodologia que a aplicaram nas agrovilas 3, 4 e 5. O modelo era o mesmo, porém com pequenas diferenças quanto ao regime de trabalho, critérios de remuneração e outras operações da gestão, que acabaram levando a desentendimentos entre os próprios assentados.

Já na área 6, após os problemas observados nas outras agrovilas, e também por conta de ser uma área emergencial, esse laboratório não foi implantado. Outro fator que possa inviabilizar, ou ao menos dificultar, de antemão a proposição do método do trabalho laboratorial é a dispersão espacial dos assentados nessa área, não possuindo uma expressiva continuidade espacial.

Uma das cooperativas onde foi realizado o Laboratório Organizacional de Campo (LOC) foi a Coprocol. Nela havia o grupo do baiano e o grupo do Paraná, tendo havido um conflito de ideias propositivas acerca de como seriam organizados os trabalhos e as funções. Segundo relatos, essas diferenças teriam elementos culturais em sua dinâmica quanto à produção, dada a experiência prévia do trabalho agrícola pelos assentados.

De aí a ideia de que sanções aos comportamentos indevidos acabavam não correspondendo ao que seria possível pelas famílias de assentados. Ao final, a falta de dimensão dos custos da aplicação da sanção, além do não reconhecimento de outros meios de promoção e manutenção da interação, também foi determinante para o seu fim.

\subsection{AS CPAS E O SCA}

Ainda durante sua formação, o projeto de reforma agrária do MST se deparou com o problema da gestão dos primeiros assentamentos. Nesse ponto, o que fica claro é a relação de estratificação das funções das organizações ligadas ao movimento. Dessa forma, o que parece estar também evidente foi a necessidade de oferecer um projeto que se contraponha àquele gestado durante os governos militares e que deu o surgimento da Organização das Cooperativas do Brasil (OCB).

Assim, o movimento gestou a criação das Cooperativas de Produção Agropecuária, as CPAs, que em seu conjunto, assim como as organizações locais 
contidas aí, constituem o Sistema de Cooperativas de Assentados, o SCA. A princípio, a organização que representaria esse novo arranjo de contraposição à OCB em seu projeto seria a Confederação de Cooperativas de Reforma Agrária do Brasil, a Concrab.

A concepção existente nesse projeto implica uma consideração na qual há uma superposição entre as duas estruturas, de acordo com seu papel, abrangência e complexidade. Isso de alguma maneira acarreta a ideia de que haja um primeiro grau que seria o mais produtivo com abrangência local; já a segunda implica uma amplificação da sua abrangência, correspondendo a uma atuação regional, ou mesmo nacional, fora do âmbito da esfera da produção, participando somente da comercialização.

Houve também uma tipologia apresentada por Bernardo Mançano Fernandes (1999) que apresentava tais tipos: Cooperativa de Prestação de Serviços (CPS), Cooperativa de Produção e Prestação de Serviços (CPPS), e as Cooperativas de Prestação de Serviços Regionais (CPSR) (Fernandes, 1999) $\square$. Em nossa observação em campo, não se constatou todas essas, apenas duas, a CPA da Copava e a CPS Coapri, que se prestariam a serviços regionais.

\subsection{O CASO DA COPAVA}

A Cooperativa de Produção Agropecuária Vó Aparecida (Copava) é uma das CPAs do SCA dos projetos do assentamento. Ela é sediada na Agrovila 3 do assentamento, pertencente ao município de Itaberá.

De acordo como se deu a proposta do movimento, é uma cooperativa concebida como de "produção coletiva", tendo sido a única desse tipo que se manteve operando desde esse período até hoje em todo o estado de São Paulo.

Para um entendimento mais claro sobre sua evolução considera-se aqui que os trabalhos de Larissa Mies Bombardi e Fernanda Thomaz são basilares para qualquer estudo posterior sobre a Copava. Neles está disposta a documentação de muitas das proposições do movimento sobre a coletivização e as contradições, encontradas ou já previstas de antemão por seus proponentes. 
O trabalho de Bombardi (2005) tem como o objetivo compreender os movimentos sociais de luta pela terra, com suas diferentes formas de luta, assim como a variedade de resultados nesse caminho. Bombardi documenta os mais diferentes cenários expondo uma primeira narrativa histórica tendo como o objeto o espaço do assentamento estudado.

Seu estudo expõe as delimitações das diferentes áreas para as agrovilas e o processo da sua formação, destacando em cada uma dessas diferentes experiências suas especificidades marcantes ou mais relevantes, para que se possa compreender diferentes fenômenos possíveis nas mais variadas gradações de intensidade nesses movimentos.

Já o de Thomaz (2010) pretende compreender as dinâmicas das experiências cooperativas de produção coletiva com o intuito de identificar limites, contradições e desafios, a fim de superá-los com propostas posteriores. Com isso, Thomaz enfoca sua observação na experiência da Copava e dos modelos das experiências socialistas precedentes, no sentido de conseguir vislumbrar avanços possíveis no sentido da construção do socialismo.

Ao contrário das demais cooperativas do assentamento, que produziam alimentos para o mercado interno, a Copava optou por produzir commodities, como no caso, a opção pela produção de soja. Dentre a produção de outros produtos considerados commodities há também a da cana-de-açúcar, porém em uma proporção muito menor, destinada apenas à produção de cachaça, com o nome de $A$ Socialista. Thomaz comenta sobre esse empreendimento:

No ano 2000, a divergência com o MST ocorreu quando a Copava optou por plantar soja, pelos motivos já citados. Em relação à soja também ocorreram problemas com os assentamentos vizinhos, no final de 2008 , devido ao fato da Copava ter conseguido plantar soja em um contexto onde nenhuma outra cooperativa, grupo de famílias ou camponeses conseguiram. Isso se deveu ao contrato com a Bioverde: a empresa forneceria semente, adubo e agrotóxicos, em troca de ficar com uma parte expressiva da produção. A Bioverde fechou contrato com os agricultores, mas posteriormente alegou não possuir recursos para o investimento com a produção. Como a Copava possuía crédito com a Agropen, empresa que produz sementes e agrotóxicos, conseguiu viabilizar a sua produção. (Thomaz, 2010, p. 155).

O presente trabalho encontrou diversos pontos convergentes aos levantados por essas pesquisas no sentido da identificação dos problemas e desafios da cooperação 
coletiva. Um deles é a identificação do problema da agência no trabalho coletivo, devido ao qual não se identifica exatamente o valor do trabalho incorporado por cada um em sua atividade, assim como não se consegue remunerar de forma precisa ou correspondente a cada um.

Figura 16 - Agente (tratorista) Principal (gestor da cooperativa)

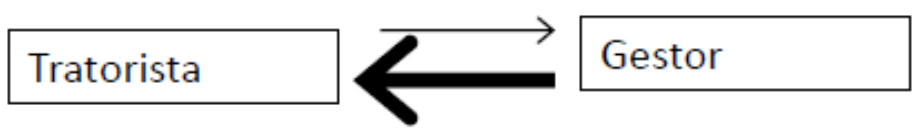

\section{Relação entre Agente e Principal}

Havendo esse problema de agência, retoma-se a questão do poder político referente à mudança institucional dentro das organizações. O caso da Cooperativa Produção Agropecuária Vó Aparecida (Copava) exemplifica isso. A Copava é uma CPA que se tornou representante do modelo de reforma agrária preconizado pelo MST. O organograma da Copava como CPA é apresentado na Figura 17, a seguir.

Figura 17 - Organograma da Copava como CPA

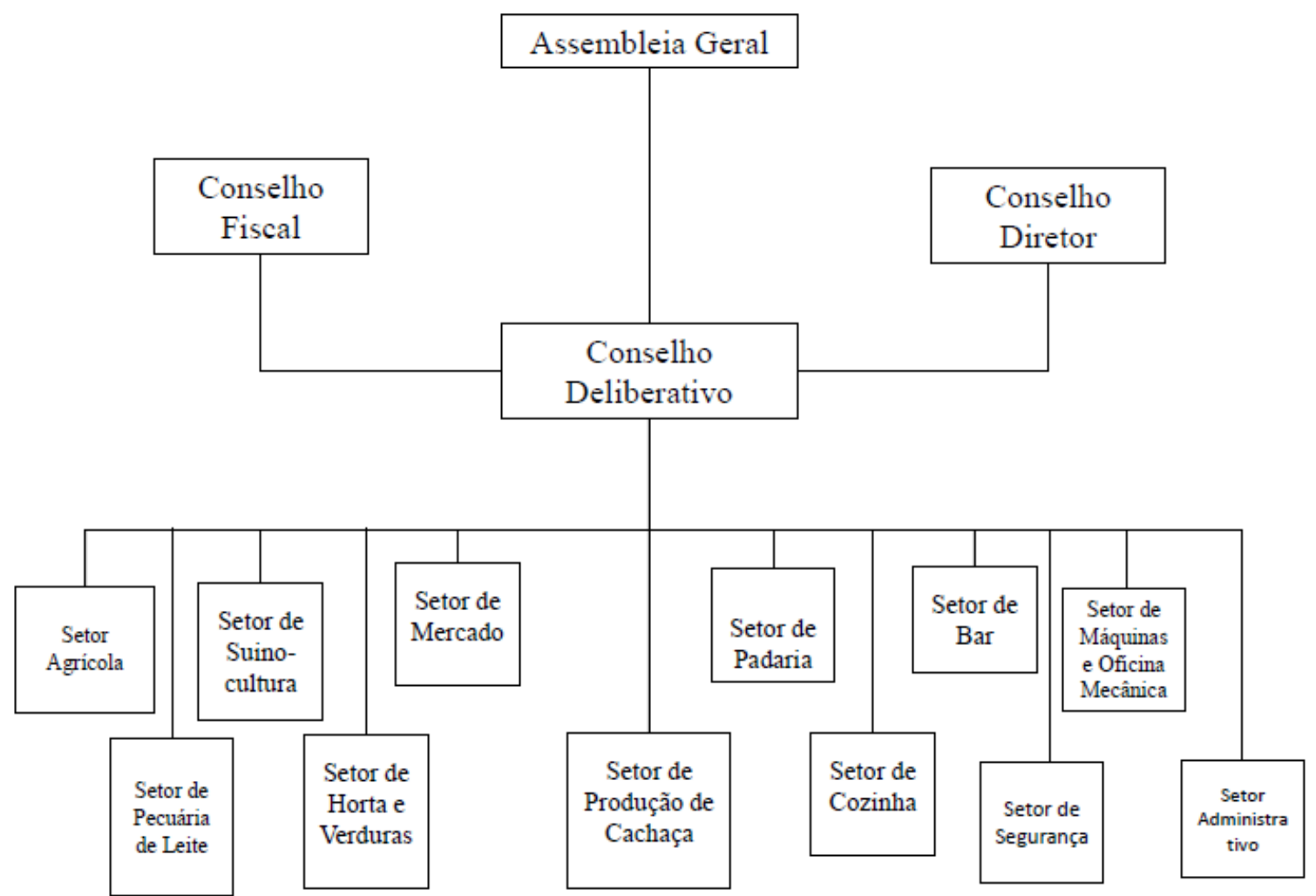

Fonte: Elaborado a partir do trabalho de Thomaz, 2010, p. 136 
Contudo, o que se observa é que, enquanto estratégia das organizações, a Copava, da mesma maneira que outras cooperativas de inspiração semelhante, tem a lógica da organização industrial de Porter na internalização das atividades adquiridas a partir das demandas dos seus membros que, por sua vez, se organizam em uma comunidade. Nesse sentido, não há um critério claro que separe a firma enquanto um nexo contratual da associação civil de seus membros, o que leva à incorporação por parte da cooperativa de serviços e atividades que extrapolam a sua finalidade produtiva comercial, constituindo uma cooperativa de tipo integral ${ }^{22}$.

Entretanto, a estratégia de coletivização observada na Copava leva à formação não apenas de uma burocracia estabelecida, mas também de um truste, onde há uma progressiva incorporação de serviços, e suas respectivas firmas, a fim de se reter a renda cedida aos provedores destes. Neste ponto particular, a recusa pode ser atribuída à percepção de que o agente com o qual se estabelece essa relação comercial realiza a exploração do produtor por parte do comerciante.

Com isso, o que se consegue observar é que há uma percepção difundida no campo não somente entre os assentados mais simpáticos ao MST, mas também entre os que até foram seus opositores, de que o intermediário é o agente que mais lhes impõe perdas na captura de renda dentro da sua posição na cadeia comercial. Essa percepção é exprimida por um dos interventores no assentamento ao refletir sobre a sua experiência de procurar alternativas de mercado aos assentados a fim de contornar essa relação.

Ao prover seus membros de crédito no mercado de itens de consumo cotidiano, a cooperativa elimina a intermediação da relação comercial de seus membros por meio de transações, o que implica a dotação monetária de seus membros para a aquisição desses itens através do mercado pagando-os em dinheiro. Nesse sentido, ao retirá-los do mercado, a direção que controla a cooperativa acaba estabelecendo e reforçando a relação da hierarquia e de sua posição de autoridade enquanto quadro gestor diante dos demais membros.

\footnotetext{
${ }^{22}$ Faço referência aqui a uma discussão da tipologia das doutrinas cooperativistas vista em Diva Benevides Pinho e Waldírio Bulgarelli. Cooperativas Integrais são, na tipologia desses autores, cooperativas que transcendem o papel de associações com a finalidade econômica por prover serviços de outras naturezas desde saúde à própria segurança e integridade dos membros da comunidade em torno à cooperativa.
} 
A Copava, por se localizar na agrovila 3, em área de jurisdição do município de Itaberá, sofre problemas referentes ao uso de bens e serviços públicos e comuns. Há uma oposição entre os assentados da 3 e da 2, até por conta da diferença radical de disposição da ocupação das agrovilas: uma individual, com casas por lotes individuais espaçadas, e a outra, como a da área 3, com a formação de agrovila central concentrada e por produção coletiva.

Entretanto, se tomadas as concepções a respeito das características da Copava enquanto uma cooperativa, vê-se que ela não corresponde à concepção de uma cooperativa camponesa da teoria chayanoviana. Se tomada a concepção de cooperativa de Emelianoff, tampouco seria a ideia de um agregado de unidades sendo, então, uma empresa de capital conjunto.

A questão da especialização do trabalho acaba por dificultar a saída da cooperativa pelos assentados. Thomaz expõe essa questão ao explicar o caso da Copava:, ao tratar do caso da Copava:

\footnotetext{
Além da polêmica sobre a localização dos lotes, ao sair da Copava o ex-sócio deve pagar as dívidas que foram feitas também em seu nome, no período em que esteve cooperado.

A responsabilidade do sócio como tal, pelos compromissos da Copava em face a terceiros, perdura para os demitidos, eliminados ou excluídos, até que sejam aprovadas as contas em exercício em que se deu o desligamento... (Estatuto Social da Copava, parágrafo único, p.4 do anexo).

Com isso o ex-cooperado que desejar trabalhar seu lote com a sua família, deverá ter uma reserva de dinheiro que lhe permita pagar as dívidas com a Copava e ainda conseguir tocar a sua própria lavoura. (Thomaz, 2010, p. 93).
}

Dessa forma, o custo da saída para um membro da Copava acaba sendo dificultado por conta desse acerto de contas. Assim, os que saíram, mas se mantiveram na agrovila, foram às suas margens, como no caso da Água Azul.

Quando a família é dominante numa organização, ela tem a percepção de que há espaço para a participação, como uma materialização da noção de democracia. Contudo, o que se pode notar é que, na verdade, a dominância de uma determinada família no âmbito da representação do agregado o que se faz é que a discussão, e sua decisão correspondente, acabam mantendo-se em uma esfera doméstica de formação. Isso pode ser verificado na fala de um dos assentados: 
Entrevistador: Quando tem uma votação por algo você se lembra da organização de uma chapa que foi vencida?

Entrevistado: Você sabe que nós, no sistema nosso aqui, só tem chapa única e dá trabalho pra montar. Viu? Não dá chapa 2. Nunca se conseguimos criar uma chapa 2 da cooperativa da Copava. Dá trabalho pra montar uma. Porque ser presidente de uma organização desse nível, exige bastante responsabilidade e nós estamos perdendo muitos responsáveis porque não é fácil. Porque não tem privilégio aqui! É como eu falei pra você aqui, não tem privilégio. Agora, eu ser vereador no município é bom. Tem privilégio. Eu ganho um bom salário. Se eu for um bom político eu posso virar um prefeito. Se eu for um bom prefeito aqui, eu posso virar um deputado. Se eu for um bom deputado eu posso ser um governador do estado. Posso até virar um presidente. Então não tem privilégio, nessa estrutura nossa. Que o sistema quer dizer 'vocês estão no lugar errado, vem com nós porque amanhã aqui você é ... hoje você é empregado, amanhã você é patrão!' Não, nós não trabalhamos essa mentalidade. Nós trabalhamos desse jeito, não tem privilégio. Então não tem chapa 2. O sindicato já tem, né? O sindicalismo já tem, chapa 2, chapa 3 , ás vezes até 4 , porque todo mundo quer ser presidente, porque lá tem um salário, é dentro do sistema [se referindo ao capitalismo] e nós somos diferentes. Nós somos diferentes. Na verdade nós somos aquilo que o sistema não gosta. [Interpretando o que diria o sistema capitalista] 'Vocês são socialistas, caminhando pro comunismo, tudo em comum' Né? O sistema é centralizar, é acumular, é ganhar mais, é propaganda, né? Pra vender mais, mas nós não tem isso. Então é por isso que eu tô te falando que nós não tem chapa 2. A chapa nossa, dá trabalho pra gente montar uma chapa única! Às vezes não dá nem eleição! Ah não, é essa chapa, vamos legalizar, a assembleia vai lá e aprova é essa, ou tem alguém [que queira ser outra chapa]? Não tem, às vezes você tem que ficar agradando o indivíduo pra ser um Conselho Fiscal. Agradando a pessoa pra ser um Vice-Presidente, um Vice-Tesoureiro. Porque as pessoas sabem que não dá mais. Não ganha mais. Tanto faz o presidente, como o associado, na atividade.

Aqui o ponto não é expresso apenas pelo discurso. As dificuldades relatadas de que exista uma chapa concorrente se deram pela falta de privilégios aos seus eleitos na cooperativa. Por exemplo, no caso do cargo máximo da cooperativa, este não tem remuneração além daquela da de qualquer outro morador.

A atribuição de que o debate é feito democraticamente ocorre porque ele é feito em uma transposição do ambiente doméstico. Porém, pode-se dizer que, além da falta de incentivos monetários, acaba-se tendo uma apatia, não, entretanto, eliminando a possibilidade de que a representação da cooperativa seja feita em torno à unidade familiar.

Segundo a avaliação de um dos responsáveis desse sindicato que atua no assentamento, apesar dos problemas existentes, e não incomuns à produção agrícola, a organização da gestão da Copava ganhou capacidades funcionais para a incorporação de inovações na produção. A esse exemplo, toma-se a organização da produção de 
horticultura orgânica feita de forma coletiva, mas com um ganho de escala sem precedentes das experiências vistas até então.

A forma da organização coletiva na Copava, como nas CPAs em geral, é a da decomposição dos momentos da produção, conformando para a sua consecução, atividades especializadas. Nesse ponto, trata-se, novamente, de uma estratégia de organização industrial.

Porém, ele tece uma observação sobre o afastamento, ou a distância, de uma parte de assentados -ou pelo menos das lideranças representantes de suas organizações-, das atividades do sindicato, por exemplo, quando este propõe a formação e a introdução de técnicas através de cursos, como olericultura e outros. Essa questão é relatada por um representante do sindicato da categoria (patronal) sediado no município de Itapeva da seguinte forma: "Há uma resistência por parte deles em se aproximar do sindicato. Nós intervimos lá”.

Diversas pessoas relataram durante o estágio de vivência que na Copava se implementa atualmente um plantio de 17 hectares de hortaliças orgânicas, uma produção excepcional para o momento e para as experiências da região nesse tipo de cultura. Como se pôde observar, a configuração desse tipo de produção na Copava se dá através da estratégia clássica da integração vertical conformando um estabelecimento único.

\subsection{COPAESE}

A Cooperativa de Produção Agropecuária Sete de Setembro (Copaese) se formou com o fim da experiência da associação na Agrovila 3. O ponto de dissidência é semelhante ao acontecido na questão sobre a Agrovila 2, a questão da 'produção individual'.

Entretanto, nesse momento o MST já dispunha de influência na região e conseguiu influenciar muitas das propostas. No caso, ao contrário do que se passou na Agrovila 2, em que a ideia de cooperação lhes era estranha, a ideia da formação de uma cooperativa logo foi tomada. Contrapunha-se, em alguma medida, à Copava, por estarem na mesma agrovila e por serem um agrupamento menor frente a ela. Assim, ela 
se forma e mantém o padrão já observado de diferenças diante de problemas sobre o uso comum de bens, da decisão dirigente e da distribuição dos ganhos da cooperativa.

\begin{abstract}
A primeira discordância entre os grupos ocorreu quando receberam uma doação de arroz arrecadada pela igreja católica. A doação veio por família e foi discutido no interior dos grupos se deveriam separar ou não uma parte do arroz para ser plantado. Como havia autonomia de decisão entre os dez grupos sobre essa questão, um grupo decidiu não plantar, alegando que na área em que o arroz seria plantado, plantar-se-ia feijão, e com o dinheiro da venda do feijão, comprar-se-ia arroz. Os outros grupos plantaram, tirando de 20 a 30 quilos de arroz por família. Diz-se que a colheita foi tão boa, que foi possível deixar semente para plantar em uma área maior. Na colheita seguinte o grupo que não havia plantado plantou com sementes emprestadas pelos outros grupos. Essa discordância já começou a demonstrar modos diferentes de compreender a atividade agrícola. Mas a discussão que culminou com o racha em dois grupos da associação, em 1993, foi a discussão sobre a sua transformação em cooperativa. As lideranças do grupo pró-cooperativa alegavam que nela o trabalho do jovem e da mulher eram passíveis de remuneração, diferentemente da associação onde a remuneração era feita por família. A intenção desse grupo era implantar a diversificação agrícola, com o cultivo de diversos gêneros, pois se perdessem uma lavoura, a outra cobriria o gasto. Além disso, o projeto desse grupo visava o crescimento das atividades agrícolas até a industrialização da matéria-prima na cooperativa. Para isso era necessário o incremento da mão-de-obra que estava trabalhando fora da associação, as mulheres e os jovens. $\mathrm{O}$ grupo que não concordou alegava que o trabalho de boia-fria dos filhos e da esposa complementava a renda da família. (Thomaz, [s.d.], p. 7).
\end{abstract}

Porém, ela acabou sendo proposta com uma diferença clara em relação às demais que era a de ser um 'grupo coletivo' e não uma cooperativa, mantendo uma relação dúbia com o SCA, pois não chega a ser uma cooperativa formalmente (Thomaz, 2010).

O regime laboral da Copaese era também feito por horas para dar base à remuneração. Porém, aqui a contradição entre os indivíduos e a família apareceu de forma a levar o trabalho ao âmbito da unidade familiar.

Porém, assim como se seguiu o padrão do problema da formação da cooperativa a partir da associação, houve também divisões no interior da Copaese. Assim derivaram a Copaese A e a Copaese B, mas que não seguiram. Segundo os relatos sobre os desenvolvimentos desses conflitos, estava, pelo menos na percepção dos relatores, a questão das disputas pessoais e familiares. 
Figura 18 - Copaese

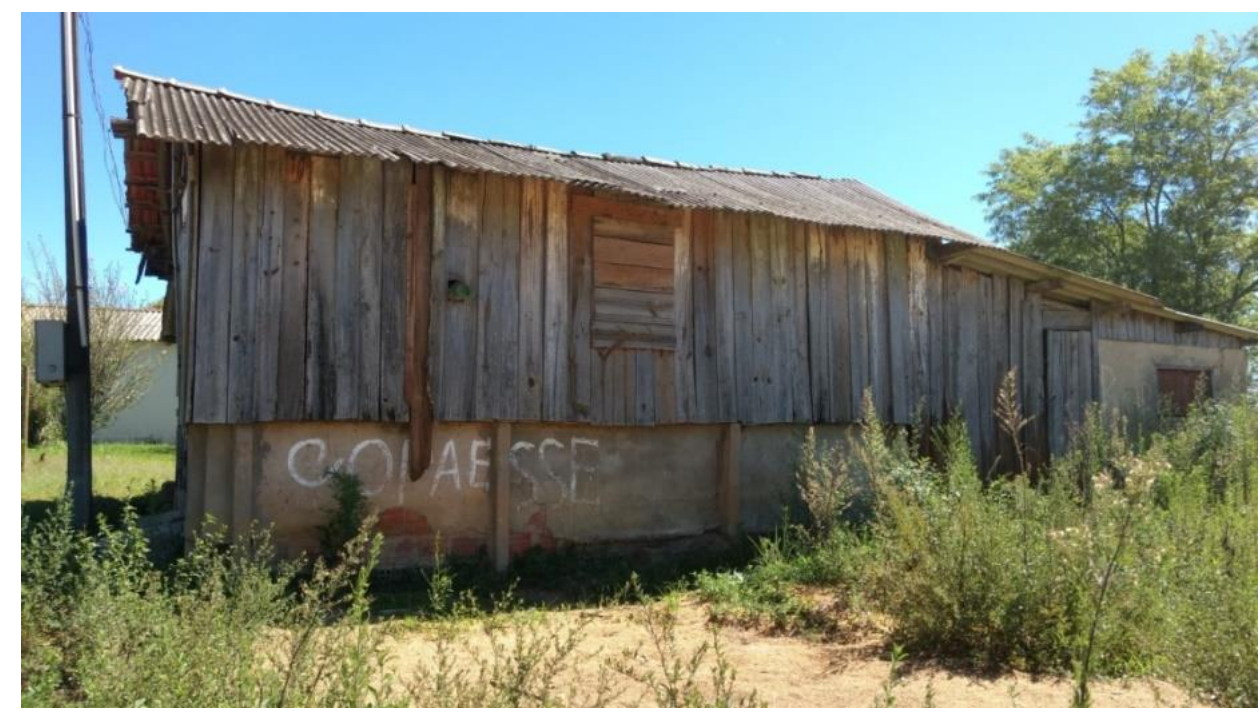

\subsection{COPANOSSA}

Sediada na Agrovila 5, a Cooperativa de Produção Agropecuária Nossa Senhora Aparecida (Copanossa) foi fundada em 1994. Resultou de um período de cerca de dois anos da formação de um grupo de trabalho coletivo, ou seja, de uma relação construída desde 1992, data da ocupação.

Assim como preconizado pelo movimento, a Copanossa correspondia a uma CPA, à mesma maneira da Copava. A remuneração dos seus membros era baseada em horas de trabalho. Porém, com o desequilíbrio entre o tamanho das famílias, outros membros da família foram impedidos de trabalhar na cooperativa, como sócios. Em outras palavras, o sócio recebia por hora e em relação à parte correspondente à sua produção, mas outros membros da família poderiam receber uma diária de trabalho.

Dessa forma, o voto e o trabalhador representavam apenas um e só poderiam representar a sua unidade familiar - uma família, um voto, uma hora trabalhada. Havia uma punição prevista de três dias sem receber para cada dia de falta e, em um determinado momento da experiência dessa cooperativa, foi vetada a participação de mulheres no trabalho da cooperativa. 
Logo, as famílias com mais filhos, ao contrário de se beneficiarem, por terem mais mão-de-obra para trabalhar, acabavam vendo-se também em precariedade, pois não conseguiriam renda para sustentá-los, além de em algumas ocasiões não terem com quem deixar os filhos, o que os impedia de ir ao campo para o trabalho. O extrato do relato explica como se dava essa relação:

Entrevistada: Tinha uma dificuldade, porque nessa época, porque nós [assentados], muitas famílias que tem bastante filhos, então às vezes eu tinha que ir pra cidade e aí ele não podia trabalhar, ele tinha que ficar com as crianças, né? Aí ele tinha que pagar três dias [três diárias sem ser remunerado]. Era um dia, perdia um dia tinha que pagar três! Aí não tinha condições.

Entrevistador: Ah, tinha uma punição?

Entrevistado: Tinha, tinha.

Entrevistada: Aí era... ficava difícil pra nós, porque...

Entrevistador: Isso é interessante saber que tinha essa... na falta de um dia...

Entrevistada: Pagava três. E era.. Isso era um dos motivos que a gente saiu da cooperativa foi isso também. Porque a gente tinha... nessa época, as crianças eram pequenas, né? Nós tivemos seis filhos. Então, né? Um perto do outro [o nascimento de cada era próximo em tempo] e daí, não tinha como deixar eles sozinhos. Aí a gente até levou um pra tomar vacina, lá no médico. Daí ele [marido] ficava com as crianças. Aí foi indo e o negócio não deu certo, né? Entrevistado: Mas a punição em si, não foi o que nos tirou da cooperativa, né?

Entrevistador: Foi o quê?

Entrevistado: Foi a ...

Entrevistada: Ajudou, né? Não foi só.

Entrevistado: Foi.... É, também foi, mas era... porque a família achava que trabalhava demais e aí não tinha tempo pra sair, pra passear, não tinha umas férias assim né? Sair a hora que quisesse. Então, o trabalho sempre vem em primeiro lugar, né? Depois os [outras coisas]...

Entrevistada: Sem contar que a diferença da Copava é que pode ter os filhos trabalhando. Se fosse nessa época, pra nós e fosse assim, dava certo. Porque lá pode entrar o filho [como sócio com direito a receber pelo trabalho], pode entrar na cooperativa. Então, mesmo que saia, saia um, mas entra dois. Então ela tem pessoas pra trabalhar e no nosso caso não. Ía saindo e não entrava outro. E aonde foi diminuindo as pessoas e daí o serviço aumentou, né? Porque continuou o serviço. Tinha que ir de madrugada tirar o leite. Pessoal aí, da.. da... tinha que madrugar lá. Foi indo e outros setores também, né? E daí as pessoas foi diminuindo e não entrava outros.

Outro ponto importante dessa experiência é que o veto à participação era seguido por um veto de representação. Com o veto à participação de qualquer outra pessoa ao trabalho na organização cooperativa, a adesão passava a ser baixa e a pressão dos membros de cada família tornava a situação do chefe que se mantinha na cooperativa insustentável, até que decidisse, por fim, sair da organização. 
Cabe aqui observar uma contradição inicial clara entre os dois entrevistados a respeito da dinâmica social e dos problemas mais relevantes na decisão pela saída da cooperativa. De fato, o recuo da posição inicial do marido, aponta para o fato de que a unidade familiar, no caso a esposa, de fato teve um papel importante nesta decisão, o que corrobora a versão apresentada por eles na entrevista.

\subsection{COAPRI}

A Coapri é uma cooperativa regional pensada como correspondente ao papel da comercialização da produção dentro do Sistema de Cooperativas de Assentados. Sediase na Agrovila 1, no município de Itapeva.

É uma Cooperativa de Prestação de Serviços, mas que também coordena atividades produtivas. Ao contrário das CPAs essa cooperativa delega aos produtores as decisões a respeito da produção no lote, assim como o método de trabalho, dado em um nível doméstico. Além disso, a Coapri se incumbe de outros dois papéis em suas atividades. A ela corresponde a gestão de projetos por meio da captação de recursos para sua execução, assim como a gestão política.

Nesse ponto, ela tem a responsabilidade de gestão da cooperativa e da gestão política da articulação do movimento no espaço do assentamento. O que atesta a sua relação com o movimento é que as portas dos escritórios da Coapri e da representação do MST na região estão uma ao lado da outra, sendo que nos fundos do aposento onde funcionam ambas as organizações, há um espaço que pode ser compartilhado.

A questão da composição dos votantes mantém a composição política com membros do MST para a atuação política. Nesse ponto, aqui eles conseguem a formação da maioria relativa facilidade. 
Figura 19 - Composição do Grupo Gestor da Coapri
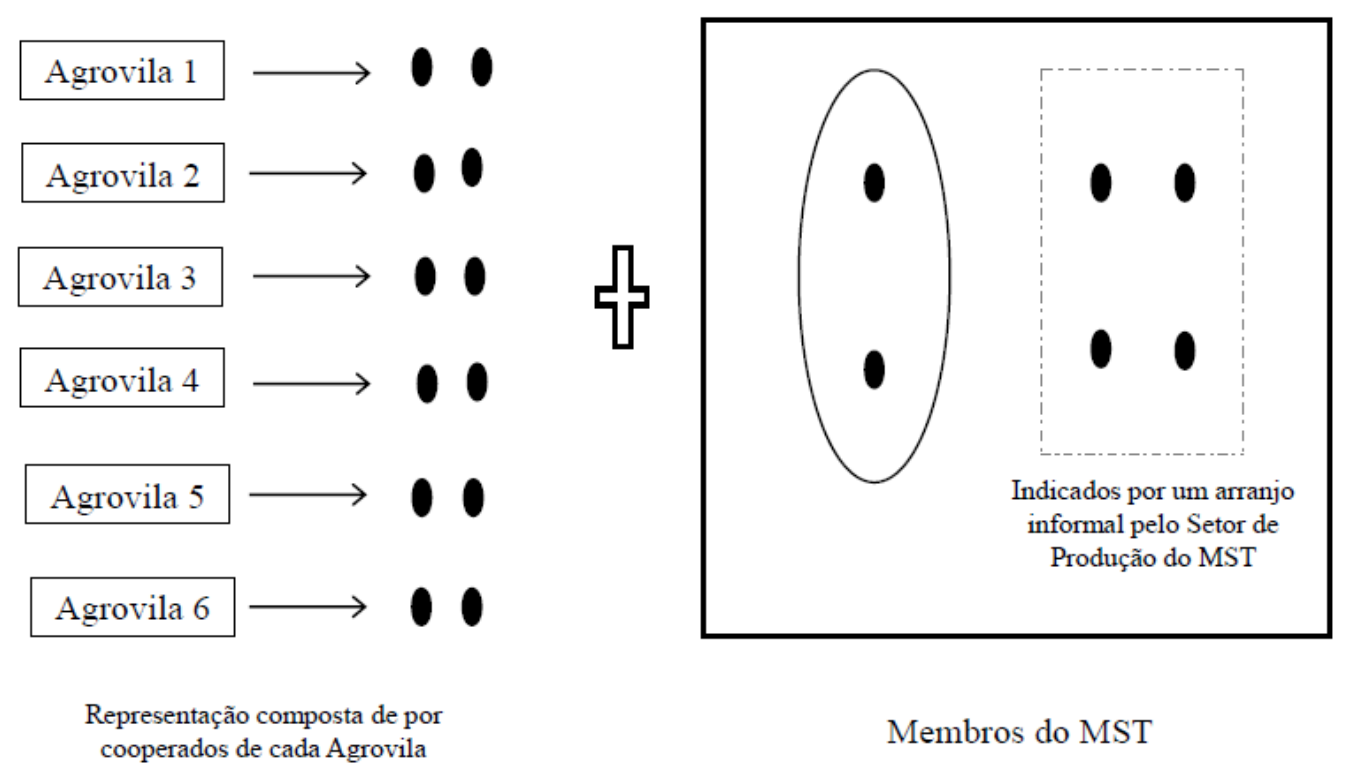

Sua diretoria é composta por 12 membros, três dos quais denominados "liberados", como se tratará adiante. Cada agrovila tem dois representantes colegiados na direção a partir de assembleias em seu respectivo âmbito, sendo para sua contagem reconhecidas seis agrovilas em toda a jurisdição do espaço do assentamento. As reuniões da direção da cooperativa são semanais.

Correspondendo à necessidade protocolar da sua regularização frente ao poder público, ela dispõe de um Conselho Fiscal e de um Conselho Deliberativo, nos quais cada um detém três titulares à função e três suplentes em caso de vacância dos primeiros.

Há a conformação do Grupo Gestor com o Setor de Produção do MST, sendo, portanto, 12 representantes do conjunto das agrovilas, somados a seis escolhidos pelo movimento, sendo que, desses seis últimos, quatro são indicados (como um arranjo informal).

O controle social das ações da diretoria pelos assentados nas atividades processuais ou cotidianas operacionais da cooperativa é previsto pelo mecanismo das assembleias. Anualmente há uma Assembleia Ordinária, mas Assembleias Extraordinárias podem ser conclamadas a partir de acontecimentos eventuais que a 
requisitem. Reuniões de avaliação de desempenho são feitas trimestralmente para conseguir manter as decisões da cooperativa.

Procura-se manter a representação feminina a partir de um sistema de incentivos à sua participação. Nesse sentido, há rearranjos de acordo com a configuração por vezes feita pela própria direção no sentido de equilibrar essa representação, já que nesse momento as lideranças da cooperativa e do movimento reconhecem a necessidade da participação feminina como forma de reforçar a representatividade do corpo gestor e decorrentes ações na cooperativa.

É através da manutenção de representantes como um conselho cativo na cooperativa e na sua representação que se tem a configuração de algum controle por parte do movimento e de sua participação dentro da organização. Nesse ponto, fica claro uma preocupação do movimento com o controle da cooperativa em suas esferas de decisão a partir da representação.

A proporção dessa representação acaba quase inviabilizando qualquer possibilidade de que uma coalizão possa manter a administração com decisão e execução de projetos que não estejam alinhados a uma linha geral do movimento representado, ou que possa mesmo angariando um apoio majoritário dos assentados enfrentar a articulação de uma decisão externa proveniente de outras instâncias do movimento. É evidente que nas votações esses representantes podem votar de forma oposta nesses foros de decisão, o que pode ser um fator de desencorajamento na participação nessa cooperativa em específico por parte do conjunto dos assentados.

Porém, ainda que possa haver uma diferença entre os próprios representantes do movimento internos à cooperativa, a própria condição de representantes os diferencia diante dos demais. Sendo assim, estando estes diante de outro espaço de sociabilização externo à cooperativa, como no caso o MST, há a percepção pelos assentados que participam da cooperativa de que esses representantes tem um comportamento comum, provavelmente por nesse outro espaço coordenarem uma ação coletiva dentro da cooperativa.

Há que se notar que, quando o impasse que gera o conflito entre os cooperados não é configurado por contornos de um conflito familiar, os relatos revelam outras características. Quando o conflito é entre famílias, os interesses são concretizados em 
objetivos claros, quanto à divisão de trabalhos, ativos, remunerações, representações e qualquer outro objeto. A lógica das coalizões se dá e a disposição das famílias imprime o seu desenvolvimento.

Porém, nem todos os conflitos necessariamente são familiares ou tornam contornos familiares. Nesse caso o conflito toma formas distintas quanto à sua dinâmica, como no exemplo do agente que não tem uma representação familiar que corresponda à sua atividade no assentamento, sendo assentado ou externo. No caso de conflitos com agentes externos, relatou-se a realização da criação de polêmicas ${ }^{23}$, no sentido de rotular essas pessoas, atingindo justamente a capacidade de articulação organizacional desses agentes.

Nesse ponto, cabe o exemplo do que foi relatado sobre um agente do ITESP a esse respeito:

\begin{abstract}
Entrevistado: E isso também é uma coisa terrível que acontece e as pessoas que fazem isso, no meu ver são muito maldoso demais, é... tudo bem, que a maioria das pessoas não consegue definir o que simplesmente significa a palavra política. Poli... várias, mais na questão de ética e tão discutido isso se é isso mesmo, entendeu? Mas eu acho que partido político é parte da sociedade que acha que tá correto aquele lugar ali, né? Agora, o que eu mais fico achando aquilo muita maldade, que não tem igual, é a campanha do ódio, entendeu? É botar a mídia pra fazer as pessoas menos esclarecidas pegar ódio, né? Eu sei que fizeram uma campanha contra o Sigismundo, de campanha de ódio ao Sigismundo... O Sigismundo é um cara que não tem um cara pra ser mais pronto do que ele, não existe. Eu não conheço. E eles [os movimentos organizados de assentados ligados aos grupos de esquerda] fizeram uma campanha de ódio contra o Sigismundo, que a pessoa falava que não gostava do Sigismundo. Aí, eu como tinha intimidade falava "Viu, mas por que você não gosta do Sigismundo?" [ao entrevistador respondiam] "Ah, eu não sei, mas eu não gosto. Entendeu? E essa campanha aí, não é só do pessoal do lado da direita que fala, mas também dentro da esquerda ${ }^{24}$.
\end{abstract}

Esse tipo de campanha, que em alguma medida inviabiliza a mobilização do capital pessoal desse sujeito, passa por compreender a relação possível entre essa personalidade conformar ao seu redor um arranjo rival ao já estabelecido. Em geral, essa campanha não é empreendida por indivíduos ou pessoas específicas, mas por movimentos organizados independente de sua natureza.

\footnotetext{
${ }^{23}$ A criação de polêmicas refere-se aqui não apenas a diferenças casuais emergentes nas controvérsias relativas ao problema de um debate, mas também como uma tática de debate empregada por correntes políticas leninistas no sentido de prevenir dissidências ou oposições à linha política dominante. Ver: (Lenine, 1902). $\square$

${ }^{24}$ Sigismundo é um nome fictício.
} 


\subsubsection{As Pessoas como ativos da organização:- o papel dos colaboradores}

Popularmente, o discurso gerencial faz uso do termo "colaborador" para os seus funcionários a fim de diminuir a sua percepção enquanto um funcionário subordinado a uma ordem de comando estabelecida pelo gestor. Aqui, o papel de colaborador é distinto.

$\mathrm{Na}$ experiência da Coapri, o colaborador se trata de um indivíduo que voluntariamente participa das atividades e cumpre papéis na cooperativa. A contraparte pela prestação desses serviços não é obrigatória, ainda que exista.

Comenta um dos assentados sobre sua experiência como colaborador e como se deu a limitação dessa forma de participação na organização: "Eu fui colaborador por três anos, mas estava deixando as coisas da minha família de lado e acabei precisando deixar de lado pra cuidar das minhas coisas".

\subsubsection{A Emancipação Feminina}

As relações de gênero demonstram ser fundamentais para a articulação da ação coletiva. Há uma tendência à articulação ser promovida por meio dessa clivagem. Isso se dá pela existência da compreensão de espaços masculinos e femininos. Tanto no convívio social, como na divisão das tarefas.

\subsection{COOPLANTA}

Entre os problemas relatados nas experiências cooperativas precedentes está o do desafio da chefia familiar masculina, por conta da articulação de coletivos de mulheres. Nesse ponto, é a partir da organização e de um espaço social de articulação e ajuda mútua de mulheres em seu universo que se consegue meios de configuração de sua autonomia.

Um caso particular desse tipo de fenômeno é o da Cooplanta em que, como relatado em nossas entrevistas, assim como levantado por Fernanda Thomaz (2010), 
houve a articulação através de uma suíça conhecida como Isabele que morou durante o período de dois anos no assentamento $\square$.

Nesse período ela teria dado um curso incompleto sobre como empreender e manter essa cultura; deixou seus materiais antes de voltar e, mesmo sozinhas, as outras mulheres conseguiram manter as suas atividades. O grupo de mulheres continua atuando na produção de plantas medicinais.

\subsubsection{Da Copafasp À Apalufer}

Outro caso mais recente se dá na Agrovila 2, na qual se criou a princípio um entreposto de comercialização da produção de hortaliças, que passou a conformar uma associação de produtores da própria agrovila, num processo que se deu entre os anos de 2004 e 2006. Dado o inicial sucesso das atividades empreendidas, houve uma ampliação das atividades exercidas na associação com a incorporação de um tanque refrigerador de leite.

O trabalho tinha uma clivagem de gêneros quanto ao labor físico, o transporte e carregamento de caixas mais pesadas, pois era em geral feito por homens. Já trabalhos ligados ao empacotamento, limpeza e outras questões eram realizados pelas mulheres.

Quanto ao trabalho burocrático, os atributos físicos, naturalmente, perdem importância. A princípio, relata-se que as atividades da gestão eram em sua maior parte exercidas pelas mulheres.

À medida que a associação ampliou sua clientela e ganhou relevância aos trabalhadores transeuntes, as mulheres se organizaram em um coletivo que passou a prover alimentação, com refeições em diferentes períodos a esses trabalhadores.

Com a predominância feminina nas atividades mais importantes da associação, passa a haver resistência dos homens. Esta se materializa em uma ação, quando se discute a transformação da associação em uma cooperativa em 2004, diante de uma parte dos membros, na maioria homens, para que as atividades na cooperativa fossem exclusivas para as hortaliças e que se interrompessem aquelas exercidas exclusivamente pelas mulheres nas dependências da recém-criada cooperativa. A partir da tomada de 
poder e da intransigência dos homens em transformar a associação em uma cooperativa, criou-se a Cofasp.

Esse movimento tinha por trás uma articulação dada por um membro do Itesp que incentivou esse grupo a transformar a associação em uma cooperativa. A diferença era relevante por conta da natureza jurídica entre as organizações, pois a cooperativa poderia ser uma organização com fins lucrativos.

Porém, a intervenção externa, nesse caso, demonstra que a perspectiva de maximização de lucros pode, ao contrário do que se suporia, desagregar a articulação social em torno da organização. Isso se dá por conta do acirramento das disputas dos recursos da cooperativa como um todo.

Essa desagregação levou ao declínio das atividades da cooperativa, mesmo esta tendo estrutura disponível para o aumento delas. Na Figura 20, a seguir, nota-se a disposição de um refrigerador de leite num galpão, o que propiciaria a atividade de um laticínio - este operou até a crise entre os membros da cooperativa.

Figura 20 - Galpão vazio com refrigerador de leite da Cofasp

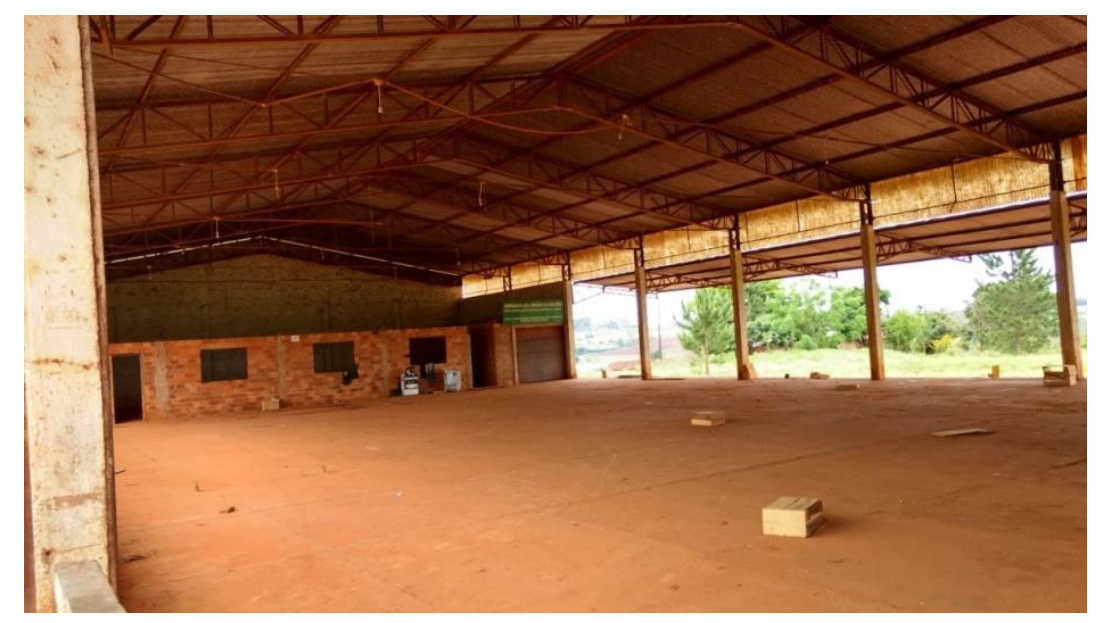

Assim, mesmo diante dessa oposição, as mulheres que trabalhavam nesse grupo se mantiveram na cooperativa. Segundo o relato, chegaram a trocar a fechadura do escritório, até que um dia viram seus pertences deixados à frente da entrada das dependências da cooperativa, além de ter havido uma intervenção policial no sentido de expulsá-las da cooperativa. 
Nesse caso específico, a saída das mulheres levou consigo os seus respectivos maridos, como atestado no relato a seguir:

Entrevistada 1: Se eu soubesse que ia ser daquele jeito eu não tinha aceitado. Porque primeiramente foi fundado um entreposto. Entendeu? Um entreposto. E depois né? Que fomos vendo o pessoal chegando e o engenheiro na cabeça nossa sabe? Pra fazer cooperativa que ia abranger ao redor inteiro, ia ser bom pra todo mundo. Aí vai que veio um lá de São Paulo ele que fez os papel pra nós da cooperativa. Aí rapaz do céu, virou um brigão! Tinha que ser um 'X,' [quota] um cooperado ' $X$ '. E aí não dava certo porque os outros queriam entregar coisas pra gente e essa turma não deixava pegar!

Entrevistada 2: A diretoria não deixou.

Entrevistada 1: Não deixava pegar a mercadoria sua se você não fosse sócio. Por exemplo, eu era sócia e você não é sócio. E você chegava lá com o seu produto, a diretoria não deixava pegar o produto seu. Você não era sócio e eles não deixavam... Cansou de ficar produto fora...

Entrevistada 1: É, do barracão.

Entrevistada 2: Por causa dessa... dessa briga e que a gente achava sempre muito ruim.

Entrevistada 1: Eu achava, não sei... Na minha cabeça era assim: o sócio era sócio. o outro não era, mas não tinha problema!

Entrevistada 1: Aqui era um entreposto.

Entrevistada 2: A mercadoria era igual! E ia pra firma que a cooperativa mandava. Mas foi uma luta.... Foi uma luta grande.

Revoltadas, algumas dessas mulheres resolveram criar outra associação, a Associação de Produtores Agropecuários Luís Fernando (Apalufer), também conhecida como Associação de Pequenos Produtores Rurais da Agrovila 2.

Ainda que tenham conseguido muitos avanços no sentido de manter, cabe lembrar que durante a entrevista notou-se que várias mulheres vinham ao encontro da entrevistada pedindo auxílio e providências de diferentes naturezas -inclusive tendo emergido um relato de violência doméstica ocorrido no período do estágio em campo.

O apoio de mútuo das mulheres nesse tipo de questão parece ser um objeto de atenção que propicia a formação de estruturas de reciprocidade que são aproveitadas no sentido de ser uma ação coletiva, a princípio para a defesa mútua, mas que através da 
experiência da conquista da terra essas mulheres passaram a manter essa relação com a coordenação de suas atividades tendo em vista outras finalidades, como no caso do objeto da emancipação, a autonomia financeira.

Porém, é com o auxílio do Itesp que conseguiram acessar os recursos públicos para a promoção do desenvolvimento social. A esse exemplo, aguarda-se a conclusão de trâmites burocráticos para a execução de alguns já previstos, como a construção de uma cozinha adequada à fabricação comercial de alimentos.

\subsection{UM ASPECTO PSICOLÓGICO}

Ao tratar de uma entre as várias requisições feitas a órgãos públicos e seus acessos institucionais, uma assentada relata um litígio de natureza trivial, mas que a obrigou a ir diversas vezes à representação do governo estadual na cidade próxima. Entretanto, após o litígio e da tentativa, através de outros órgãos do governo, de alcançar a resolução de tal problema, a entrevistada relata um aspecto interessante da questão na primeira pergunta feita pelo agente público a ela: "O homem [do governo] me perguntou: 'a senhora sabe escrever?'. Eu disse sei!".

Do ponto de vista racional legal-burocrático, a própria consideração de uma pergunta tal expressa a percepção que os próprios assentados tinham dos agentes com os quais interagiam. De fato, não é incomum esse tipo de consideração. Nesse ponto, o que se constatou pelo dito por ela é que, caso a resposta fosse negativa, provavelmente haveria mais um pretexto para a postergação do devido encaminhamento da questão.

Essa condição psicológica também foi observada por outros pesquisadores no assentamento, incluindo dentro do ambiente da cooperativa, como expõe Fernanda Thomaz ao analisar o discurso de um dos cooperados da Copava:

Pela fala do cooperado vê-se que ele se sente inferiorizado e até humilhado por suas opiniões serem totalmente desconsideradas em qualquer tipo de reunião (núcleo de família, assembléia, conselho, reuniões semanais). Na sua compreensão isso ocorre por ele ser "bobo, nível lá de baixo" e os que decidem serem "nível lá de cima”, ou seja, escolarizados, letrados. O cooperado se ressente afirmando que não possui, mas possui experiência, conhece o trabalho agrícola (lavoura, gado, porco), pois a sua origem camponesa foi determinante para que aprendesse o trabalho na prática, provavelmente com a sua família. A CPA, por sua vez, desconsidera esse 
aprendizado, porque seu modelo é baseado na especialização, em novas técnicas que possam aumentar a produção, e a maneira "artesanal" de trabalhar do camponês é vista como irracional e pouco produtiva. Todos esses aspectos relacionados ao trabalho na CPA podem distanciar os trabalhadores, porque diferentemente do camponês autônomo em relação à sua produção, na CPA as decisões sobre a produção, se não houver realização de reuniões e assembléias, acabam sendo tomadas em esferas que não contemplam as opiniões dos cooperados. (Thomaz, 2010, p. 153).

\subsection{OS LIBERADOS}

Na divisão do trabalho da cooperativa há uma progressiva necessidade técnica de que alguns dos membros da gestão da cooperativa passem a se afastar da esfera da produção. Assim, acaba se formando uma burocracia dentro do próprio agregado de unidades produtivas. Entretanto, há uma especificidade na formação das cooperativas do movimento social no sentido da estratificação social entre os responsáveis pelo labor da produção, a partir do seu afastamento também das atividades processuais e burocráticas da cooperativa.

É através da especialização das funções da organização que há a formação dos chamados liberados, os membros da cooperativa que passam a exercer atividades políticas, tanto da formação, quanto da militância, sendo justificada pela ideia de ação para a promoção da "intercooperação" através da atividade dos liberados.

Isso se dá pela percepção da permanente necessidade de articulação política especificamente do MST, de manter suas conexões com agentes públicos e privados, assim como com outros movimentos e organizações. Essa coordenação existente teria como finalidade coordenar campanhas com a finalidade de que se pudesse avançar na perseguição dos objetivos da agenda do movimento.

Há, portanto, uma derivação da organização por parte dos membros da cooperativa não apenas na configuração de uma burocracia com finalidade funcional ou técnica diante da realização da produção, mas sim na constituição de uma organização derivada que, além de um quadro administrativo de gestão, atua potencialmente como um partido. Em alguma medida pode-se considerar que, enquanto tal, essa organização derivada pode se aproximar daquela formada por políticos profissionais conforme 
preconizada na doutrina leninista, a depender do nível dessa profissionalização dessa atividade política.

Aqui cabe a apreciação da dissertação de mestrado de Cleci Behling da Silveira (2003) sobre a Lei de Ferro da Oligarquia, de Robert Michels. Ele teorizou a respeito das organizações sindicais e de partidos e acabou desenvolvendo a concepção das oligarquias formadas a partir da ideia da substituição das elites pela mudança social. Ainda que Michels considerasse a concepção do materialismo histórico, comum a Marx, para a análise do desenvolvimento da sociedade humana ele não se alinhava à ideia da formulação de uma organização como a saída para a superação da condição precária dos trabalhadores por elas representadas.

Segundo Silveira (2003), Michels travaria uma diferença com as interpretações das concepções de Michels em relação ao uso dos termos: democracia e oligarquia.

A democracia, em seus termos, seria o autogoverno da massa, ou do povo em uma concepção geral. Dessa forma, o que se pode entender é que a concepção de Michels se dá a partir da ideia de uma relação da representação dessa comunidade a partir de uma relação direta.

Já a concepção de oligarquia concerne um governo de poucos, ou de uma minoria. Nesse sentido, mesmo com a pretensão da formação de uma associação representativa de uma classe ou de uma categoria laboral, ao haver essa representação o que se observa é que há um destacamento que governa para si baseado em poder nos demais da mesma categoria.

\subsection{ELEMENTOS DA GESTÃO POLÍTICA}

Ao observamos a relação que se dá entorno aos administradores das organizações associativas pode-se constatar que há uma preocupação latente com a coesão dos seus associados. Nesse ponto específico, a ideia da burocracia como responsável pela administração política é mais evidente.

A operação da gestão política tem como categorias de sua análise a percepção dos indivíduos enquanto ativos da organização. Em outros termos, uma das funções da organização é a mobilização de seus membros, sendo nesse ponto eficaz. 
Contudo, ao observarmos do ponto de vista do processo administrativo que se faz nas organizações, a ideia de que os seus membros sejam ativos é suplantada pela concepção de que os membros são rivais. Sendo assim, pode se dizer que a gestão pensada a partir da concentração e da alocação dos recursos a partir de uma perspectiva econômica faz com que os gestores pensem os associados como clientes, com os quais se mantém uma indução de interações transacionais, ou seja, há uma ideia de uma manutenção dos associados como membros que executem uma ação coletiva com fins sociais.

\subsubsection{A formação política}

A atividade de movimentos sociais e ONGs é um importante meio de instrução dos assentados. No caso do MST, a formação política é uma das atividades com maior alcance entre os assentados.

Tanto em relação à formação das mentalidades, como diante dos problemas da sua mobilização frente a desafios já enfrentados no passado. Porém, o que se pode observar é que essa relação de instrução política e formação de pessoas, também para a ocupação de seus quadros, inclui um intercâmbio com mobilizações externas ao escopo da questão da terra e extrapola o nível nacional.

O intercâmbio de experiências não se trata apenas de uma forma de instrução, mas compreende uma oportunidade de articulação distinta, além de conseguir atrair recursos disponíveis por membros dessas outras organizações.

A imagem que se expressa no quadro da Figura 21, a seguir, contém indicadores do alcance dessa articulação. Nota-se que há mensagens deixadas em espanhol por pessoas que passaram pela região naquele momento, provavelmente no mínimo de países latino-americanos, da própria Espanha metropolitana, ou em sua amplitude máxima hispanófonos de colônias espanholas de outras regiões do mundo fora da América Latina, como as Filipinas, ou de hispanófilos, isto é, descendentes de comunidades de hispanófonos vivendo em outras áreas. 
Figura 21 - Foto do quadro do Cristo Redentor com as mensagens

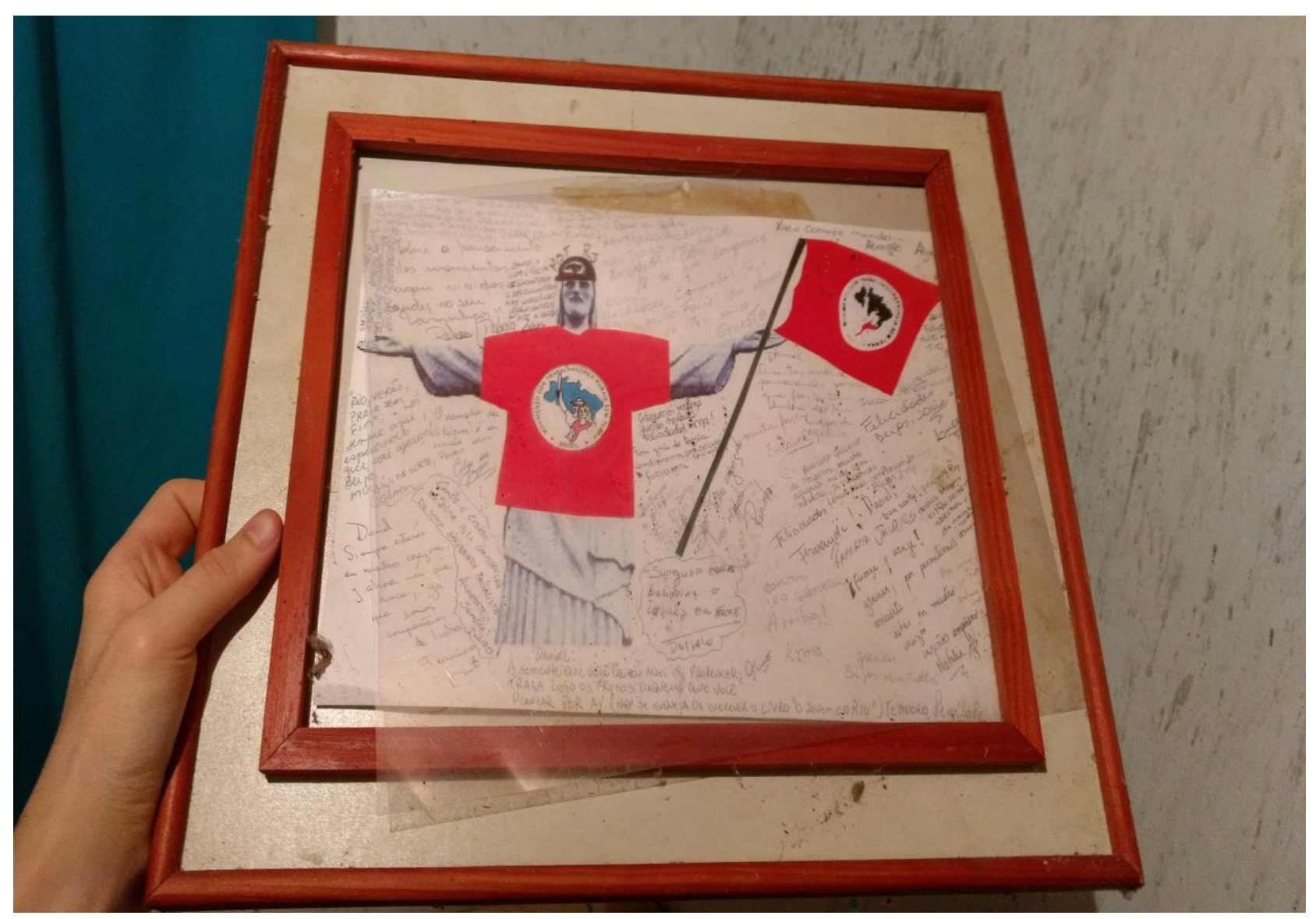

Qualquer que seja a proveniência dos autores das anotações, contata-se que houve a promoção uma articulação internacional presente no assentamento. No relato que segue, de um assentado testemunha-se a relação que havia entre os agentes sociais, das mais diversas origens e organizações, articulados ao MST em sua presença na cooperativa: "Lá eles tinha conseguido várias coisas [...] apesar que aquele alojamento lá era casa dos holandês [...] [veio gente de vários países]veio da Venezuela, da África, Angola... [...] conseguiram fazer banheiro seco [...] placa solar...”.

Essas informações dadas nesse fragmento do relato são confirmadas no relatório da Secretaria de Desenvolvimento Territorial do Ministério do Desenvolvimento Social e Agrário (SDT/MDSA), que trata das dependências existentes na região e destaca esses elementos excepcionais. Contudo, aborda esses elementos como um dos exemplos da 
impossibilidade de aporte de capitais sem antes uma preparação organizacional dos próprios potenciais beneficiários dessa política:

\begin{abstract}
No que tange às organizações dos trabalhadores do campo, estão presentes na região o Movimento dos Trabalhadores Sem Terra - MST, os sindicatos de trabalhadores rurais ligados à Federação dos Trabalhadores na Agricultura do Estado de São Paulo (Fetaesp), e os sindicatos da agricultura familiar ligados à Federação da Agricultura Familiar de São Paulo (FAF-SP). O Movimento dos Trabalhadores Rurais Sem Terra (MST) está presente especialmente nos assentamentos da fazenda Pirituba em Itapeva e Itaberá, assentamentos antigos que pelo que foi observado têm sérios problemas no aspecto da organização da produção e da organização social, mesmo tendo uma das principais lideranças estaduais do movimento assentada em uma das áreas. $\mathrm{O}$ assentamento possui uma cooperativa com uma boa estrutura, galpões e casa de beneficiamento de mel, mas com frágil organização. (Favareto, 2007, p. 21).
\end{abstract}

A ideia da baixa visibilidade de algumas áreas do assentamento, por conta da atração dos externos pelos locais onde os movimentos sociais estão mais fortes, também é presente. Como consequência, a própria atração de capitais, investimentos e promoção de projetos acaba concentrada pelos próprios movimentos, mesmo que a iniciativa parta de agentes externos e não necessariamente de uma atuação deles. Essa ideia pode ser corroborada pelo relato de viagem de um dos pesquisadores do Ipea com técnicos do Incra de São Paulo:

\footnotetext{
Entre os dias 18 e 27 de fevereiro, o pesquisador visitou, em companhia dos técnicos de campo do Instituto Nacional de Colonização e Reforma Agrária (Incra), os seguintes assentamentos: Projeto de Desenvolvimento Sustentável (PDS) Professor Luís de David Macedo, em Apiaí; 23 de Maio e Carlos Lamarca, em Itapetininga; Ipanema, em Iperó; PDS Comuna da Terra Milton Santos, em Americana; Elizabeth Teixeira, em Limeira; e PDS São Luís, em Cajamar. Fez ainda duas breves incursões a Pirituba, especificamente à sede da Copava (Agrovila III), e ao assentamento Sumaré, em Sumaré. (Disoc/Ipea), 2013, p. 108).
}

Se, por um lado, há a promoção do assentamento e da atração de projetos para o assentamento, por outro, o que ocorre é a concentração da implementação dos projetos, assim como da atração de recursos internacionais em algumas áreas, não havendo disposição de articulação com as demais. Entretanto, observa-se a necessidade de buscar áreas marginalizadas do assentamento para a implementação desses projetos, já 
que estas acabam negligenciadas de atenção por parte dos próprios agentes públicos, como demonstrado pelo relato do técnico.

A centralidade do MST enquanto interlocutor e articulador desse tipo de arranjo é reafirmada no referido relatório do Ipea de 2013. A relação entre o movimento e a provisão de recursos para a sua realização é dada por meio de uma articulação que extrapola uma atividade determinada prevista por organizações cooperativas desprovidas da condição de ser simultaneamente um movimento social:

\begin{abstract}
Para resumir o ocorrido, utiliza-se aqui a conclusão de artigo que descreve o referido processo. $\mathrm{O}$ artigo registra uma ação de política pública que está apresentando resultados promissores. A atuação do Incra ocorre em parceria decisiva com a organização social dos assentados - no PA Pirituba II, o MST é o parceiro fundamental. Esta atuação conjunta possibilita ao Estado exercer função catalisadora que, como consequência, leva ao envolvimento de outros atores sociais, como é o caso das prefeituras locais, universidades e organizações da sociedade civil. Contudo, é importante afirmar que a ação catalisadora, por si só, é insuficiente. A própria experiência no Pirituba II assim o demonstra. É preciso que o Estado disponha de instrumentos de atuação, ou seja, atue por meio de políticas públicas efetivas e consistentes. A "história recente da política agrária no Brasil continua a mostrar fraco desempenho e inconsistências. (Disoc/Ipea), 2013, p. 86).
\end{abstract}

\title{
5.24.2 A gênese da burocracia das associações
}

Um dos temas das contradições existentes nas unidades associativistas do assentamento diz respeito ao domínio das funções burocráticas que acabam por influenciar os temas de interesse nas assembleias e nos foros de decisão das unidades associativas, associações ou cooperativas. No início da história do assentamento, grande parte dos assentados era analfabeta e não conseguiria acessar os cargos das funções burocráticas do assentamento.

Dessa forma, programas de alfabetização foram fundamentais para a capacitação de potenciais gestores e para a inclusão dessa parcela da população na participação da gestão dos problemas da ação coletiva. É esse recurso de capital humano que faz com que haja um potencial maior por parte dos assentados em participar e assim influenciar a atividade do trabalho da cooperativa. 
tem com o trabalhador ligado à produção uma relação equivalente à da burguesia. E, tomada dessa forma, a análise de Michel Crozier sobre a sociedade francesa e o seu fenômeno burocrático chega a uma conclusão que se pode de forma indutiva tomar aqui que é a da centralidade da família, e de seu chefe (seja qual for o gênero) é a unidade fundamental para a análise de uma estratégia social. Isso se revela também nas relações entre as famílias no domínio das funções da cooperativa. (Crozier, 1981, p. 388-389).

Segundo o relato de um dos assentados, houve uma manobra para afastar a oposição proveniente da área 2 ao se alegar a dificuldade, por conta da distância, dessa com as demais agrovilas. Isso pode ter se dado por conta da diferença em relação ao controle social que é exercido através da aproximação das casas em agrovilas. No caso da agrovila 2, a dificuldade desse exercício por meio da organização do movimento, acabou, por um lado, enfraquecendo o controle da direção do movimento sobre os assentados da área, e, por outro, desagregando a mobilização ao longo do tempo.

\subsubsection{Mecanismos de prevenção da instauração da oligarquia}

A princípio se relata o conhecimento de instituições, por parte dos assentados, no sentido de prevenir a instauração de um grupo oligárquico na cooperativa, como já dito a respeito do rito da votação das assembleias com votação por maioria simples.

Outro instrumento para a prevenção dessa instauração é a proibição da reeleição por parte da presidência a partir de um número determinado de mandatos. A esse respeito Araújo trata da função operacional das assembleias da seguinte forma:

A presença às assembleias e a entrega da produção são duas formas do exercício de participação e cooperação. [...]. As instituições favorecem a que as classes sociais possam revelar em seu interior relações determinadas, através de recursos de poder. Mesmo porque só existe posição de dominação sobre a condição de existência de setores a ela subordinados. No entanto, a ideia de participação não se limite a uma vaga afirmação valorativa, deve indicar que grupos, setores ou classes são capazes, num momento dado, de mobilizar e organizar setores socialmente dominados para que estes tratem de obter seus objetivos sociais. (Araújo, 1982, p. 134).

\subsubsection{O fenômeno do contrapeso do poder}


Diante da crescente organização de alguns movimentos, dentro do assentamento há o acirramento das contradições entre os próprios assentados. Porque há uma articulação entre os membros das cooperativas e organizações externas ao assentamento, como no caso do MST como organização fonte do poder, por parte de representantes das cooperativas há a tentativa da operação por parte dos assentados da sua voz dentro da cooperativa.

Contudo, com o fechamento dessa perspectiva, ou com a diminuição do custo de saída por conta de a associação com agentes externos ter fins econômicos, com elementos da propriedade enquanto fonte de poder, as diferenças internas se tornam cismas que podem dar origem a organizações rivais.

O fenômeno mais relevante a respeito desse tipo de movimentação foi a da criação do Movimento dos Assentados Independentes (MAI), a respeito do qual o entrevistado observa que: “A 1 e a 2 não tem movimento. Já eles [assentados das demais áreas] foram criados por movimentos. E eles querem que a gente vai pro movimento, só que a gente vai assim (indicando uma resistência em aceitar a liderança do movimento) [...]."

Figura 22 - Movimentos dos Assentados Independentes

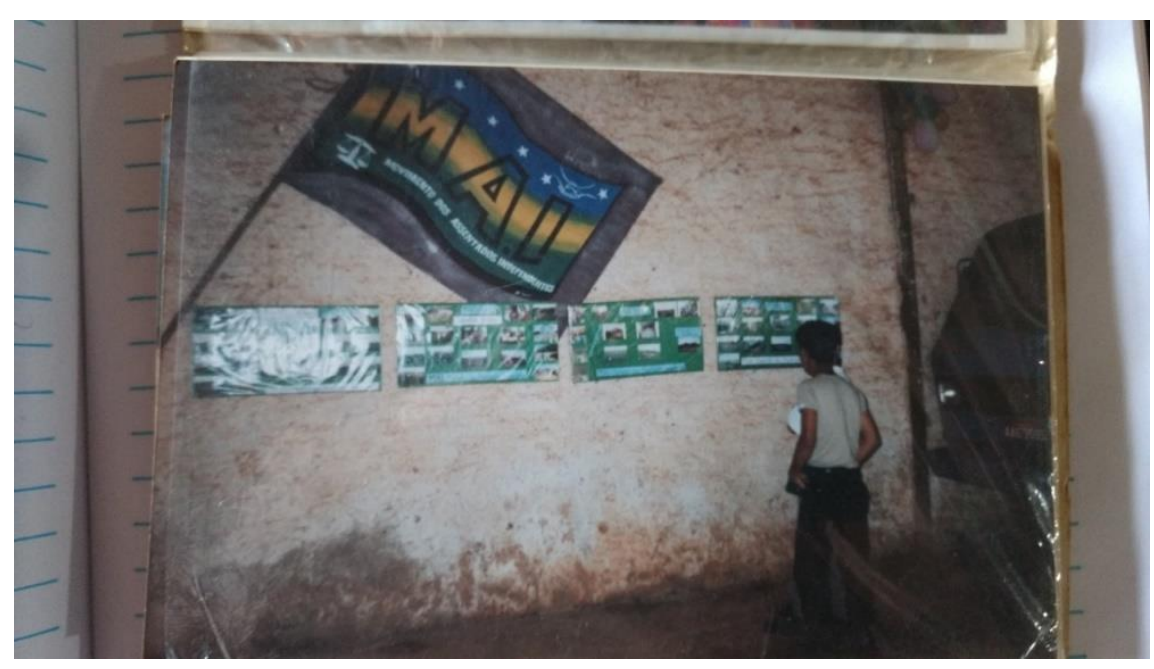

Como se pode observar, as referências simbólicas desse movimento fazem ponto a ponto uma oposição ao MST que era o movimento proeminente à época. Há referências às cores nacionais, à exclusão do uso do vermelho e ao termo 
"independentes" —que aludia à contraproposta de centralização, provavelmente observada à época.

Esse movimento foi criado em resposta à crescente centralização das decisões vistas nas organizações, em que a direção política tinha ganhado robustez a ponto de funcionar enquanto uma burocracia, ou ação política profissionalizada.

Entretanto, deve ser lembrado que a criação desse movimento se deu por uma distorção do papel da atuação de agentes públicos, que acabam por observar uma necessidade da fonte do poder da organização, mesmo enquanto elementos do poder público. No caso específico do MAI, relatou-se a indução à organização por parte do agente como forma de angariar recursos para fazer frente a outros movimentos, mais especificamente ao MST, no campo político.

Ao contar a relação que tinham com o agente do ITESP que empreendia essa ação no assentamento, um assentado conta:

\footnotetext{
Entrevistado: Ele comprava briga!" A palavra dele era lei! [...]. Em 2005 - fez uma instrução na lousa - fez cálculos - uma dívida de 700mil reais à época[...] Entrevistado: Ele chegou a prejudicar eu na cooperativa!" Duas carretas de tratores cheios de quiabo ele não queria receber elas!
}

Nota-se que a restrição, ou fechamento das vias comerciais, tinha como finalidade reservar um determinado dispositivo institucional que viesse em suporte exclusivo aos cooperados a fim de fidelizá-los. Entretanto, a interrupção da interação materializada por esse embargo (como interrupção de fornecimento), ou boicote (como interrupção da aquisição), inibia o engajamento dos assentados no arranjo comercial.

Tratava-se da instauração de uma instituição alheia aos assentados, de forma absolutamente artificial a sua atividade. Nesse sentido, a provisão de um bem coletivo, como no caso dos membros da cooperativa, não poderia restringir o seu uso pelos que não seriam membros apenas para o cumprimento de um objetivo do quadro gestor.

Isso não quer dizer que os assentados não tenham já a compreensão do que é a propriedade. Ao contrário, concebem a propriedade de um determinado bem, instalação, instrumento ou meio; o que não concebem é o seu não uso sem contraparte possível. Em outras palavras, se aceita que se exija uma compensação pelo uso desse recurso alheio, mas não a manutenção da sua ociosidade tendo como objetivo a eficácia do embargo 
comercial que, como se interpreta aqui, tinha a finalidade de forçá-los à entrada na cooperativa - que inclusive propôs bloqueio da passagem de caminhões que fariam o carregamento das mercadorias dos demais.

Nesse ponto, pode se observar que, se houve alguma concepção de intervenção agrária, a ação dos agentes públicos, quando projetada a partir de aspectos da heterogestão, acaba não tendo eficácia para promover arranjos e propor soluções baseadas na forma da organização social. A resistência dos assentados a esse tipo inadequado de intervenção é exposta no seguinte relato de um assentado: "Ele escrevia na lousa um plano e você tinha que executar o que ele falou! ”.

Dessa forma, o relato expõe um problema de intervenção agrária que se observa na percepção da atuação individual do agente do ITESP. Sem nenhum amparo legal para atuar em nome da instituição, o agente acabava contrariando os próprios assentados:

Entrevistado: se não tivesse muito a influência dele brecar.. de querer brecar a prefeitura, o movimento dos sem-terra a entrar e ajudar, porque dai ajudava né? e aí crescia.. Fico parado... Ele queria só ele e nós.

A preocupação do objetivo do gestor em alcançar seus objetivos restringia as alternativas e o volume de interações possíveis para os assentados e para o quadro gestor, tendo em vista sua busca pela aplicação de uma sanção ineficaz contra os rivais. Nesse ponto, o objetivo era apenas do gestor, que impunha o custo da decisão para o alcance de seus objetivos ao produtor da cooperativa.

O discurso no caso é revelador também enquanto uma percepção da contradição desse fato. A expressão "entrar e ajudar" significa, na verdade, que se espera que o sujeito com o qual se trata saia da sua condição de gestor e entre no espaço social contribuindo em suas atividades, estando então, desprovido da veste hierárquica do comando.

Outra experiência desse fenômeno do contrapoder relatada no assentamento foi relativa à formação de outro movimento, o Movimento Sindical da Agricultura Familiar, ligado à Contag. Seu objetivo era a aproximação dos agricultores da sua esfera de atuação direta e passa por uma concepção da agricultura familiar, enquanto uma categoria representada pela organização. 


\subsection{A PACIFICAÇÃO DO ENTORNO DO ASSENTAMENTO}

Após a instalação do assentamento entre saídas ou expulsões de assentados e ingresso de novos, os remanescentes da oposição do processo de instalação acabam, por sua vez, mantendo-se apartados. Não havendo essa pacificação, decorre um distanciamento da associação econômica dos agentes produtivos, que acabam por perder oportunidades de atuação e ganhos em diversos mercados, assim como acesso a recursos para a sua inserção e incorporação no mercado.

A esse exemplo, toma-se a atuação de uma cooperativa de laticínios que tem origem na colonização holandesa na região. Mantém-se um distanciamento entre assentados e produtores de leite da região devido à oposição da parte dos holandeses envolvidos no litígio do processo de assentamento da Fazenda Pirituba II.

Nesse sentido, mesmo que não sejam necessariamente os mesmos colonos holandeses, ou mesmo que nem tenham relações entre si, há uma representação persistente do seu sujeito social e da repulsa à associação com eles por conta do conflito durante a disputa pelo domínio das terras.

\subsubsection{A crise do ITESP diante dos movimentos sociais}

Inicialmente, a atuação dos membros do ITESP era vista como tendo sua autoridade emanada por um critério técnico-científico. Entretanto, é no desenvolvimento das questões políticas enfrentadas pelos movimentos que se observa uma fonte de contestação dessa autoridade.

Atualmente, os próprios funcionários do ITESP se mobilizam em torno de uma campanha salarial, e parece haver pouca conscientização de sua condição por parte dos membros de gestão das organizações presentes no assentamento, assim como por parte dos assentados em geral.

A relação dos assentados com o órgão varia, pelo que se pode constatar, de acordo com a agrovila. Ainda outro ponto fundamental é que tanto os assentados que conseguem uma melhor inserção no mercado e necessitam de ingressos de capitais para qualificar sua produção, quanto os que se estabeleceram quando o órgão já existia em 
sua atual configuração percebem o ITESP como um opositor de seu sucesso e do desenvolvimento do seu negócio.

A não possibilidade de dotação de títulos de propriedade acaba sendo percebida por esse tipo de assentado como uma vontade, ou um objetivo do ITESP. A ideia é que essa dotação poderia aumentar a capacidade dos assentados de conseguir crédito à parte dos já concedidos pelos programas de apoio aos assentados.

Nesse sentido, há uma incompreensão em relação ao papel do órgão e de suas habilitações, já que é uma prerrogativa federal. Assim, pode-se dizer que o ITESP acaba envolvido em uma situação de desgaste em que, por um lado, é o responsável pela promoção do nível de vida dos assentados, e, por outro, é o obstáculo deste próprio.

\subsubsection{A Questão das Propostas Queimadas}

Um dos agentes externos que atua no assentamento relata a delicada situação da proposição de uma determinada intervenção. Propostas inovadoras, com projetos das mais diferentes naturezas foram apresentadas e continuam a ser. Porém, o dano ao potencial de articulação da comunidade é posterior ao próprio fim do empreendimento, conforme se expressa o assentado entrevistado: "Você queima essa proposta. Se você começar com essa proposta, você vai queimar e pro pessoal voltar de novo... O pessoal quer saber [falando] 'Viu? Eu quero sobreviver! Né? Eu quero vender meu produto, quero que o meu produto seja bonito!'”.

Um dos problemas apontados nos relatos coletados não é diretamente o do insucesso direto de uma determinada proposta, mas sim as consequências para qualquer alternativa, por meio do associativismo. Em outras palavras, a partir do que foi relatado e do que se consegue apreender pelo discurso dos assentados, é a ideia de que o insucesso de uma empresa cooperativa, ao contrário de um empreendimento individual ou sem sócios, tem seu desencorajamento amplificado, conforme se depreende da seguinte fala de um assentado: "Na verdade o povo 'eles' tinha medo, né? Por causa da associação não ter dado certo, então o povo tinha medo de se juntar de novo... em cooperativa, por causa daquela associação".

Aqui o termo "eles" se refere ao conjunto dos associados aos quais para o emissor da frase, se extrapola o seu espaço doméstico. Assim, o que se pode dizer que é 
que o reconhecimento deste seria equivalente ao feito com a alteridade da cooperativa, mas com a diferença de que a organização, o "eles", é representado por uma instituição como um ente superior, no caso a cooperativa, como no trabalho de Silvia Maria Pereira de Araújo (1982).

Um ponto relevante constatado na análise é: há uma solidariedade quase generalizada pelos assentados aos que participam ou estão em processo de acampamento. Isso, em alguma medida, ultrapassa diferenças cotidianas entre os assentados.

Porém, registra-se que muitas vezes a ajuda, por não ser percebida como equivalente ou mútua, não confere a essa interação social uma estrutura de reciprocidade que possa desenvolver a coordenação de outras ações coletivas no sentido de auferir à articulação entre os assentados, habilidades organizacionais mais complexas. Exemplo de percepção de não reciprocidade que se dá pela falta de apoio dos assentados da área 3 a eles, na narração do caso da doação de trabalho da parte deles para ajudar a área 3 quando esta precisava:

Entrevistada 2: Quando eles precisavam nós ajudemos com os trator nosso foi lá né? Trabalhar pra eles. [...]. Eles ficaram oito anos na beira da estrada. Então eles ficaram à beira da estrada com criança sabe? Aí os trator nosso foi trabalhar lá muitas vezes. Produtor nosso trabalhou lá pra eles fazendo terra. Inclusive quase que um vizinho nosso perdeu a vida lá. Que abriu lá o... a tampa lá do tanque do trator né? Quente, fogo com o óleo veio tudo quente nele. Quase que morreu, ficou entre a vida e a morte, né? Nós nunca negou auxílio e ajuda.

A gestão das informações por parte dos movimentos de ocupação em suas atividades políticas é percebida pelos assentados. Um dos relatos dos assentados quanto a essa assimetria de informação é descrito aqui: "Segredo. Eles tinham segredo com a gente sabe? A gente tinha medo de acontecer qualquer coisa. E eles falavam pra nós. Olha, se vocês vão sair por aí, saiam de bandinho. Não saiam sozinhos. Tinha jagunço aqui!"”.

Porém, uma vez mantida essa assimetria na relação dos assentados com o movimento, mesmo posteriormente à conquista, há uma indisposição. Nesse ponto, a ideia de accountability acaba não sendo correspondida. Gera-se uma opacidade 
institucional, dado que a finalidade política de uma determinada postura dos gestores quebra a concepção de uma interação recíproca.

\subsubsection{O simbolismo dos elementos de cultura material}

O uso do trator é de referência ao fato de que há a percepção pelos assentados de que este tenha o valor símbolo, ou seja, em si, a representação do sucesso enquanto agricultores. A ideia da aquisição de um trator individual estabelece a questão da superação da visão do agricultor rústico, como no caso da imagem proposta por Kalervo Oberg (1965), como a do camponês marginal produtor de alimentos numa economia de subsistência (Oberg, 1965) $\square$.

Figura 23 - Tratores da primeira Associação do movimento

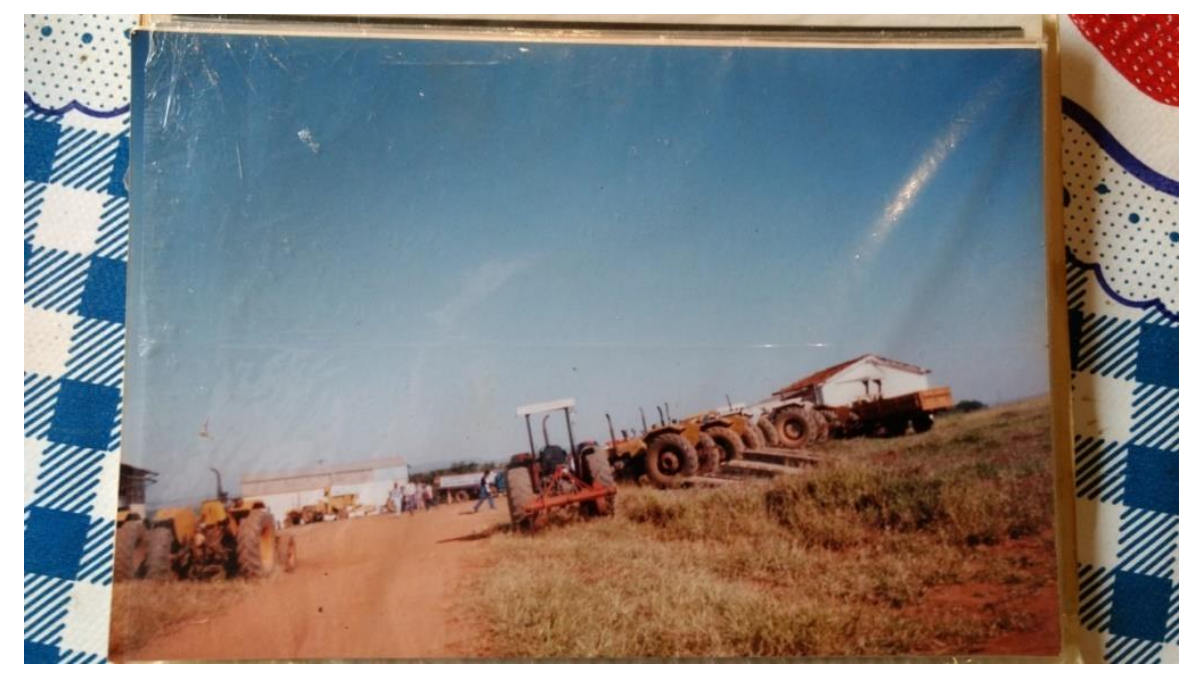

O trator, assim, além um bem de produção, é aquele negócio de patrimônio. Essa relação é expressa pelo assentado no controle do seu uso pelo patrão ao manter o controle sobre o seu uso: "Trabalhei com trator muito pouco [tempo]. Fui tratorista muito pouco [tempo]. Porque o patrão não liberava muito o trator. Era só pra fazer um serviço de colheita de feijão. Leva um produto e trazer e eu aprendi tudo.”.

Porém, há a questão do paradoxo da modernização quanto a sua introdução. À medida que há a introdução recursos tecnológicos, há uma transformação da própria condição dos arranjos. Um exemplo da imposição da condição tecnológica da produção 
é a do próprio maquinário. A aquisição de maquinário de proporções adequadas ao tamanho dos estabelecimentos no assentamento é um limitador.

Isso se dá pela condição de que as máquinas existentes, e mesmo seus implementos, assim como o volume de insumos utilizados, foram projetados para estabelecimentos de maior área. Isso fazia com que o aproveitamento do ingresso de capital fosse também limitado, já que a máquina poderia ficar muitas vezes ociosa, ou se ela tivesse um alto custo de manutenção para uma atividade.

Outro ponto em relação ao trator é a concepção clara existente diante da divisão do trabalho a partir do gênero. O papel de tratorista, ao passar a existir nos estabelecimentos, é, de acordo com a observação feita aqui, um trabalho reservado aos homens. A condução da máquina é um papel masculino, assim como a aplicação de venenos.

Há a possibilidade de que essa condição da divisão do trabalho mude, pois tecnicamente é possível que as mulheres possam tomar essa função. É frequente observar mulheres conduzindo outros veículos como motos, carros, camionetes e mesmo caminhões-baú. Contudo, por nós, não foi observada nenhuma tratorista mulher durante as estadias em campo.

\subsection{DOS DOCUMENTOS DE REGULARIZAÇÃO}

A polêmica sobre a persistência ou não de uma sociedade camponesa no campo brasileiro rendeu diversos debates. A observação aqui não se refere necessariamente ao debate, mas sim a um aspecto importante para a questão da inserção social do assentado.

Ao serem perguntados sobre o que se imagina a respeito do seu próprio imaginário sobre o campesinato, em suas reações, os assentados demonstram os sentidos mais comuns às referências de sua caracterização. Dentre essas ideias ligadas ao campesinato estão: a do a social, a do atraso, do passado, ainda que se possa dizer

que culturalmente se recorra a essa referência como sendo o elemento de autorreconhecimento diante de outros que estariam fora dessa comunidade imaginada ou projetada. 
Porém, há uma evidência comum entre diversos assentados que é a percepção de prestígio social, ou de ascensão social a partir da posse do "talão rural" ou da DAP. A concessão de um determinado direito que autoriza o assentado a fazer algo que outros não teriam a permissão, autoridade ou perícia para a sua execução, como no caso da comercialização da produção sob sua responsabilidade, ou até mesmo o direito como a aposentadoria, eleva a posse desse documento não tomado apenas como uma documentação. Isso nos leva a compreender que essa instituição é encarada como um ativo, ou mesmo um privilégio.

Assim, a autonomia para a comercialização da produção, materializada pela posse dessa autoridade, implica superar uma necessidade de articulação com outros produtores para a sua inserção comercial, ao passo que também confere um direito de propriedade do qual se pode extrair renda ou benefícios ao prover o serviço de "venda" a outro produtor sem a regulamentação, ou com pendências de uso. Com isso, essa posse extrapola a subjetividade suposta de que ela seria apenas uma representação idealizada, tendo, sim, consequências reais e objetivas na ampliação das oportunidades de negócios desses assentados, assim como de sua ascensão social.

\footnotetext{
Entrevistado: Eu tive tanta dificuldade na Copava. Os primeiros [assentados do assentamento] o pessoal mais antigo que vieram. Não tinha.... Não tinha documento, era analfabeto, não tinha às vezes nem RG. E eu brigando com eles falando 'gente' vocês precisam tirar documento, porque amanhã você vai completar 60 anos você vai ter que aposentar. E a pessoa [interpretando a sua resposta] 'Não, não precisa nada'.
}

Essa espécie de "ativo institucional" compreende também uma preocupação comum com a regularização desse mercado institucional. Nesse sentido, há oportunidade de concepção da atividade institucional da organização derivada do agregado das unidades que vá além da facilitação, assistência ou serviços prestados ao domínio da produção.

Outro exemplo disso é a Declaração de aptidão do PRONAF (DAP), que certifica o agricultor para que ele possa participar das políticas públicas. A própria ideia de que o produtor tem a partir disso uma permissão que outros não teriam, como um mecanismo de privilégio, acaba também reforçando a sua condição. 
Há um elemento que não pode ser verificado a partir das observações, da imersão e das entrevistas, que diz respeito ao caráter previdenciário. A documentação que atesta o seu papel produtivo é a que atribui ao assentado o acesso à previdência.

Porém, a capacidade de articulação de ação coletiva em torno à manutenção, ou não, desse direito não pode ser verificada. Não é possível aqui prever que tipo de organização resultaria desse tipo de ação. Limita-se aqui a constatar que o regime previdenciário pode ser um fator político futuramente no assentamento.

\subsection{A QUESTÃO DAS COMUNIDADES MORAIS}

Um dos fatores importantes de articulação dos assentados e de sua compreensão da realidade social passa por sua confessionalidade. Nesse ponto, cabe observar a relação entre os católicos e protestantes e os adeptos de outras religiões no espaço do assentamento.

Há uma relação observável entre a capacidade de articulação dessas comunidades diante dos movimentos presentes no assentamento. Os espaços religiosos são potenciais dinamizadores de articulações para ações coletivas como se revela aqui:

\footnotetext{
Entrevistado: No horário do aviso. Que é o horário do aviso. 'Quem tem algum aviso?' O padre falava, sei lá ou o dirigente da comunidade. Eu erguia a mão. 'Eu tenho um aviso! Depois da celebração, todos os sem-terra [é pra] reunir aqui na Igreja pra nós conversar'. Porque eu ajudei a construir a Igreja, então eu tinha meus direitos né? Embora, perdi os direitos de dirigente, de coordenador, porque eu era meio louco, meio doido né? Mas eu fazia bem a reunião. Aí aqueles dirigentes [da campanha da fraternidade na Igreja católica] que eram meio contra a reforma agrária, mas eram proprietários de pequenas terra, tinha medo, do Cleber ${ }^{25}$ reunir grupo e punha na terrinha dele né? Então, eles ficavam assim, meio querendo ficar. Eu falei 'não, é só os sem-terra. A reunião é só de sem-terra. Homens e mulheres que queiram participar da luta pela terra'. Mas ficava quase que a metade da comunidade ali dentro. A maioria era sem-terra ali do bairro [rural de sua origem]. Aí, isso me, isso foi o início meu. Isso que me levou a essas.... a essa ideologia da luta pela terra e eu tô até hoje, né?".
}

${ }^{25}$ Cleber é um nome fictício. 
No momento da instalação do assentamento houve um apoio de amplos setores da Igreja católica, sobretudo dos membros ligados à Teologia da Libertação, o que proporcionou os meios da inserção dos membros atuantes de sua igreja, a princípio.

Contudo, esses setores eram externos à área dos assentamentos, referidos como sendo padres de São Paulo. Das autoridades locais da Igreja, relata-se a oposição ao representante da Igreja católica que leva a um afastamento desta dos espaços do assentamento.

Isso faz com que a representação do catolicismo rústico, observado no campesinato brasileiro, desenvolva especificidades, assim como a aceitação de outras organizações religiosas. Porém, não se puderam constatar características utilitárias da sua perspectiva religiosa, como observado por Wolf no seu estudo do campesinato. $\mathrm{O}$ papel da Igreja nesse momento de formação de mentalidades fica aqui demonstrado:

Entrevistado: Se for lá no início [da minha vida]. O que me levou eu a fazer tudo isso? O que me levou eu a ser esse tipo de pessoa foi a própria Igreja, em 1980. Fui coordenador de jovens, fiz parte da Pastoral da Juventude, coordenava um grupo de jovens lá num bairrinho rural onde eu morava, nos tempos das campanha de 'pão pra quem tem fome'. Terra de Deus, terra de irmão [Campanha da Fraternidade] aquelas coisas, foi aí que a Igreja me enfiou na minha cabeça e depois tentou tirar, mas daí não saiu mais, né? Me ensinaram isso e depois quiseram me desensinar, mas aí não deu. Não vocês falaram que era isso, então vamo tocar, né?

Entrevistador: Como que é? Me desculpe a pergunta. Me explique isso aí. Entrevistado: Não é que em 1980, 1981, 1982 e 1983. Eu fazia parte da Pastoral da Juventude. Eu era jovem ainda, fazia parte da Pastoral da Juventude. E nos temas de Terra de Deus, terra de irmão, pão pra quem tem fome, aquelas coisas da campanha da fraternidade, tem uns seminário e me levaram eu lá. Eu fui e a Igreja me colocou um monte de coisas no miolo. Sobre Reforma Agrária, sobre direito à terra, né? Que Moisés, não sei o quê... terra prometida, aquela coisarada toda e que hoje tá passando até nas novela aí e eu peguei aquela coisarada. Depois eu comecei a levar aquilo na prática. Porque era só teoria, né? A Igreja era muito teórica nessas coisas, aí eu botei isso na prática.... Nos anos, 1985 eu casei. Em 1986 eu tava reunindo um grupo... em 1985, em 1986 nós viemos pra cá. Com um grupo de pessoas, porque a ideia era colocar esse negócio aí. Depois ela [a Igreja] tentou através de padre, de bispo "ô, Cleber, pera lá!" Ué? Mas não era isso que me ensinaram? Eu vou continuar fazendo. Me expulsaram da Igreja. Fui expulso em 1985. Quando eu casei. Eu casei e ... não é que me expulsaram, me tiraram do cargo [de Coordenador de Jovens]. Porque eu falava da reforma agrária.

Entrevistador: Você não foi excomungado, não é?

Entrevistado: Não cheguei a ser excomungado, mas me tiraram do cargo, mas eu ... como me tiraram do cargo, mas me ensinaram a fazer isso [a luta] falei, então eu tinha um espaço pra ali na hora da celebração [ter a palavra]. 
À medida que mais especificamente o MST passa a concentrar o apoio e a coordenação das atividades dos assentados, observa-se que setores de inspiração marxista conseguem progressivamente impor seus quadros no movimento, afastando, ou neutralizando, o papel dos próprios setores da Igreja que apoiaram a formação do movimento e do assentamento. Assim, há um declínio relativo na proeminência da presença da Igreja Católica nos espaços onde o MST é mais presente, como no caso das agrovilas $1,3,4$ e 5 .

Porém, o enfraquecimento relativo da presença desses dois setores da Igreja católica não necessariamente fortaleceu a posição do MST no assentamento. Ele abriu espaço, no sentido da questão da economia das religiões ${ }^{26}$, para a entrada de grupos religiosos rivais aos católicos, mas tão ou mais opositores ao movimento, como no caso das igrejas neopentecostais.

Entrevistado: Hoje eu tô na Igreja evangélica de um louco que é a do Wardomiro do chapéu preto. [...]. Eu tô aprendendo muita coisa do evangelho naquele, daquele camponês. Naquele como diz, pegar a história dele 'disvalidade' [invalidez] de quando ele foi moleque ele foi excluído da família. Ele era o pior da família, hoje ele é o cara que a multidão anda atrás dele. $[\ldots]$

Entrevistador: Mas ele chega a ter representação aqui?

Entrevistado: Tem. Em Itaberá e aqui. Tem um grupinho aqui que eu faço parte $[\ldots]$

Entrevistador: Mas qual que seria a postura do pastor Waldomiro em relação à reforma agrária?

\subsection{A CONSTRUÇÃO DA IGREJA NA VIA PRINCIPAL DA AGROVILA 1}

Há uma disputa da ocupação dos espaços no próprio assentamento. Eles revelam a capacidade de outras organizações atuarem no assentamento com consentimento de parte dos próprios assentados, seus apoiadores, e revela uma oposição clara entre estas organizações e o MST.

\footnotetext{
${ }^{26}$ Aqui a referência é feita à disciplina de Economia na Ciência da Religião. Uma de suas referências é Rodney Stark e Laurence R. Iannaccone, que basicamente tratam do fenômeno do capital religioso e do crescimento ou da diminuição do tamanho dos grupos confessionais, suas transformações institucionais e suas adaptações diante de diferentes contextos.
} 
Segundo os assentados, havia um acordo para que a ocupação de espaço para fins confessionais fosse feita em uma rua específica da Agrovila 1, uma travessa da estrada principal que liga as agrovilas 1 e 4 . Porém, fez-se a construção dessa igreja na via principal da agrovila. A princípio, esse acontecimento seria provincial se não fosse revelador da própria condição dos meios condicionantes da ação coletiva.

Ao interpelarem os responsáveis e ao tentar acessar as instituições responsáveis pela legalização da tal construção, deram-se conta de que o trâmite burocrático para construí-la já havia sido efetuado. Diante da aprovação da construção pelas próprias autoridades responsáveis, os opositores à construção dessa igreja na via principal se resignaram.

Esse fato revela um elemento além da correlação de forças no assentamento. Mostra também o acesso aos espaços do poder público que proporcionam sua ocupação, quando antes pareciam ser exclusividade das organizações de pressão ligadas ao MST. Isso representa um caráter concorrencial da articulação do movimento e de seu reconhecimento diante dessas autoridades, além de um desafio ao nível organizacional da fonte de poder da organização, no caso da organização do movimento diante da organização dessas igrejas.

\subsection{A REJEIÇÃO DA COMERCIALIZAÇÃO VIA COOPERATIVAS}

Compreender a relação da disposição dos dotes na barganha entre os assentados e cooperativas implica observar uma rejeição por parte delas aos assentados. Esta se dá pela percepção por parte dos assentados de que, em vez de a cooperativa ganhar renda a partir da reunião de recursos numa competição no mercado e ampliar o seu poder de barganha em forma de maiores rendimentos, a cooperativa, por não ter poder de barganha numa competição externa transforma-se em um entrave custoso à relação de mercado. A Figura 24, a seguir, apresenta esse mecanismo.

Figura 24 - Mecanismo de barganha intermediando cooperados e mercado 


\section{Cooperado $\longleftrightarrow$ Cooperativa $\longleftrightarrow$ Mercado}

Assim, diante das dificuldades encontradas na competição de mercados, num momento de crise do setor, por exemplo, uma vez estabelecido um grupo burocrático que represente a unidade da cooperativa, é por meio dessa representação que o sentido da dinâmica da barganha da relação entre cooperados e a sua gestão se torna competitivo e não cooperativo. O quadro dirigente da cooperativa se volta a capturar renda em detrimento dos seus próprios cooperados.

No caso da associação, por não ter fins lucrativos, essa evolução é atenuada, já que seu quadro dirigente não tem, teoricamente, essa necessidade. Além disso, observase que a participação menos burocrática e processual facilita a participação dos assentados, pois estes se tornam capazes de operar a organização, mitigando o problema da assimetria de informações quando a associação passa por dificuldades, transparecendo o cumprimento de suas funções e expondo um problema que não lhe corresponde, como no caso, uma diminuição da atividade no setor, como citado anteriormente. 
Figura 25 - Ata das reuniões de mobilização do assentamento
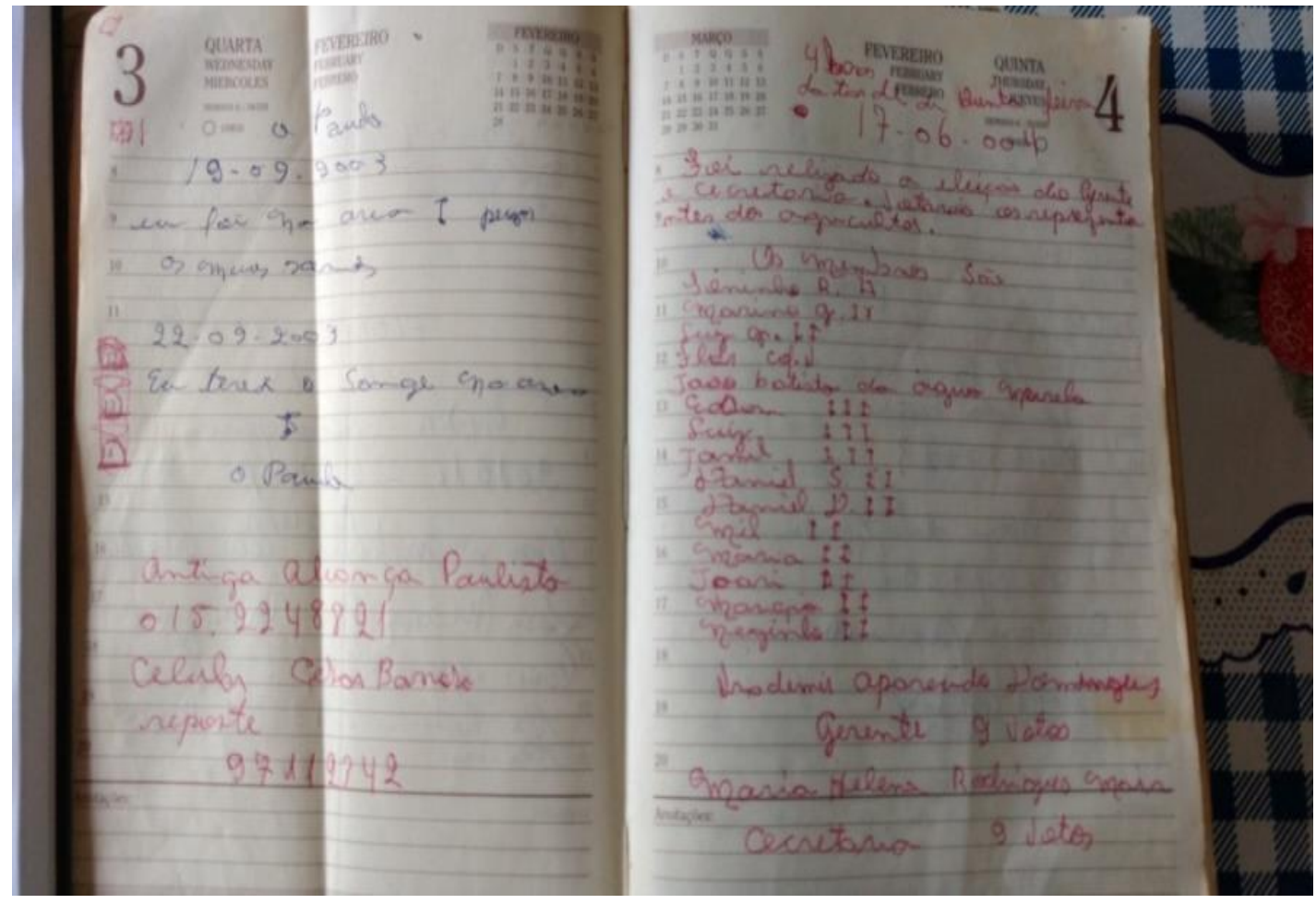

Há uma concorrência dada pela estrutura de mercado dos serviços a serem oferecidos pelos assentados nas próprias dependências do assentamento, relativos a refeitórios e marmitas, como na Copava e no projeto da Agrovila 2. Contudo, não se nota uma integração entre as atividades. Como as dotações parecem ser as mesmas, há um acirramento das condições de mercado dos próprios empreendimentos dos assentados das agrovilas dentro do assentamento.

\subsection{A CASTROLANDA}

A partir da cidade de Itararé, fronteiriça entre os estados de São Paulo e Paraná, houve a chegada de colonos holandeses na região. Esse movimento de colonização é contemporâneo ao de outras colônias entre o final do século XIX e o começo do século XX. 
Entretanto, a partir do assentamento das famílias holandesas forma-se ao entorno a sua própria comunidade étnica uma experiência associativa que se materializou na formação de uma cooperativa, a Copassul. Esta se baseava na comunidade holandesa e se dedicou a manter a produção de grãos, integrando-se no cenário tradicional das cooperativas brasileiras capitaneadas pela Organização das Cooperativas Brasileiras (OCB). Segundo um entrevistado: "A Castrolanda superou um problema que haveria com a Copassul, pois essa cooperativa estava diretamente ligada aos holandeses envolvidos no conflito com os assentados.".

Um aspecto fundamental é que os holandeses membros da Castrolanda são percebidos como grandes produtores pelos assentados. A percepção da sua dominação e de sua oposição é revelada em alguns relatos. Larissa Bombardi (2005) explica a questão do significado do uso desses termos:

\footnotetext{
O camponês, não fortuitamente, usa as palavras "pequenos" e "grandes" como sinônimos de "pobres" e "ricos". Mostra a oposição de tamanho revelando a oposição da condição social diferente; e, por meio desta, a condição política também diferente pois, no caso vivido por eles, a mediação política era sobretudo uma mediação econômica. Os "grandes" garantiam seu acesso à terra - que era político e subordinado à ação privada do agrônomo através de seu poder econômico (Bombardi, 2005, p. 590).
}

Como dito anteriormente, a relação de uma parcela dos assentados que viveu o momento do acampamento em que houve o conflito com os holandeses deixou máculas nas interações entre eles e os assentados. Porém, com outros elementos, observa-se uma diferença das experiências relatadas entre as cooperativas que propõem formas associativas alternativas, como de características sindicais ou de classe, ou a partir de modelos alternativos de produção.

Se no momento da instalação de áreas mais recentes, a partir da área 3, a relação conflituosa com holandeses rendeu uma cisão entre os assentados ligados ao próprio movimento que afasta as duas partes de manterem melhores relações, esse afastamento não é apenas pelo conflito. Persiste entre os assentados a ideia de que a Castrolanda seja apenas para grandes produtores e que as associações criadas para os pequenos produtores tinham esse papel de integração e comercialização da produção dos pequenos, como, no caso, eles mesmos. 
Contudo, há uma alteração vista nessa situação a partir da própria integração de produtores do próprio assentamento, sobretudo com a relação comercial que se tem pelas lojas ligadas à cooperativa que atendem sem restrições aos próprios assentados.

Um dos assentados explica em seu relato como houve um incentivo em voltar a sua produção às necessidades dessa cooperativa. Isso se deu a partir de uma experiência inicial em que ele deixava de ser estritamente um agricultor e passava a manter um gado de leite.

Assim, como observado por Araújo (1982) nota-se que esse assentado incorpora elementos ideológicos da cooperativa, no caso a Castrolanda e adota um discurso de coproprietário do patrimônio da cooperativa: "Eu sou empresário rural e o laticínio é nosso!"

Ao tratar da sua relação com a cooperativa e com os holandeses dela, fica claro que, para ele, que acessou o lote através da lista do cadastro do ITESP, essa questão não se põe. Questionado se da parte dos holandeses houve alguma indisposição ele relata que o disseram: "Essa é uma questão superada".

Quanto a isso, há uma fetichização clara da relação entre a cooperativa e a sua mercadoria, na qual o seu associado faz parte. Assim Araújo (1982) explica:

\footnotetext{
O fetiche não se dá apenas enquanto produto agrícola-mercadoria, que se transmuda aos olhos do agricultor cooperado. Como a "força fantasmagórica de uma relação entre as coisas, a própria entidade é para ele um fetiche, já que não consegue apreender as complexas relações que se dão em seu interior e mais aquelas que ela mantém com o exterior (Araújo, 1982, p. 168) $\square$.
}

Uma das diferenças relatadas pela forma de aceitação na Castrolanda é que há uma verificação de desempenho inicial para que, se o produtor provar que consegue corresponder a esse nível, poderá participar da cooperativa. É um nível mínimo que deve ser alcançado para o ingresso e monitorado para ser mantido.

Esse mecanismo de verificação de desempenho não está presente nas cooperativas coletivas ou individuais nas experiências dos produtores do assentamento. Nesse ponto, há o pré-requisito de um nível de produtividade mínimo que coloca a questão da busca por ingressos de capital na sua produção.

Alcançado esse nível de produtividade e de qualidade, passa-se ao rito de aceitação desses produtores na Castrolanda a partir da votação em assembleia. Os 
aceitos fazem um cursinho de aprendizagem e conhecimento organizacional para trabalhar com a cooperativa.

Essa verificação de competência e desempenho é uma instituição de admissão na cooperativa que acaba diminuindo a desconfiança em relação à ideia de que esteja se aproveitando dos bens comuns.

Outra consequência desse tipo de mecanismo de admissão é a ideia de que, para o produtor atingir o nível de produtividade mínimo, ele acaba tendo que assumir o risco de investimento nas atividades do setor. Com isso, ao atingir esse mínimo e poder se associar há uma relação de barganha, na qual se consegue formar um sentido da negociação em que há uma parceria enquanto o resultado do ganho de volume de produção para a comercialização. Em outros termos, há configuração da criação da consecução de um objetivo interdependente entre as partes da negociação.

\subsection{DA ESTRATÉGIA DAS ORGANIZAÇÕES}

Os estudos em estratégia em economia das organizações, ao conceber os custos de transação na análise, tendem a compreender a questão entre adquirir ou integrar processos a partir de uma visão heterogerencial. Consequentemente, imprimem um sentido de diminuição progressiva dos custos da transação, que se materializa na redução do aparato burocrático que se configura ao entorno da sua unidade de análise, no caso a transação.

Porém, no caso de organizações associativas, que buscam empreender transformações sociais ou políticas no âmbito institucional há a consequente necessidade da organização enquanto uma burocracia. Nesse ponto, a decisão do grupo da gestão passa por compreender o resultado da atuação política no nível da organização e em que esse resultado corresponde à necessidade da organização, dos seus membros representantes e daqueles que estes representam.

\subsection{A AGRICULTURA POLÍTICA}


Assim como a introdução de técnicas e de ingressos tecnológicos e científicos transformou a agricultura e as ciências agronômicas como um todo, no sentido da sua modernização, os métodos de gestão e comercialização, assim como as modalidades de custeio e financiamento, também se transformaram.

Contudo, há uma concepção errônea quanto ao aspecto institucional da agricultura moderna, como demonstrado pelo trabalho de Mauro de Rezende Lopes (1996). Lopes demonstra, a partir de diversas experiências de grupo de interesse, a viabilização produtiva e da prosperidade do setor $\square$.

O problema fundamental da atuação de um grupo de interesse específico para a coordenação entre a representação política e a atividade econômica agrícola. De fato, assim como a agricultura depende do ingresso de inovações no âmbito organizacional e produtivo, o aspecto político também deve ter transformações da ação política dos grupos da agricultura no sentido de conformá-la com as condicionantes impostas pela transformação dos meios produtivos.

A esse exemplo, a questão é a consideração é de que parte do sucesso desse tipo de empreendimento passa pela ação política e institucional no sentido da promoção de interesses específicos do setor. A proposição política de mudança institucional não passa por uma demanda emanada dos produtores em sua própria atividade, mas de uma proposição feita a partir da análise da direção do movimento, e que não necessariamente tem a ver com o cunho ideológico dos movimentos propositivos em questão.

Nesse ponto, o que se pode considerar é que o papel do MST, enquanto propositor de uma ação coletiva, passa pela questão de sua posição nessa estrutura de reciprocidade generalizada, tal qual formadora de um mercado de reciprocidade, a partir do fato pelo qual os elementos da estrutura do próprio movimento atuantes na área acabam tendo problemas sem não tem uma solução imediata, dada pelo ativista local, que conclua apenas ele a relação com o assentado em litígio.

Isso implica uma forma de negociação que consiga estabelecer trocas reversíveis que superem os objetivos políticos do movimento ao imprimi-los diante dessa interação, dados os condicionantes dessa estrutura. Não havendo uma representação externa à margem do contato por meio do representante local, sendo este integrante do próprio movimento, isso acaba por enfraquecer a sua representação tendo em vista a 
inexistência de mecanismos indutores de representação de demandas por parte de grupos.

Em outras palavras, a representação do movimento feita em nível local acaba por se configurar em um mercado no qual a atuação do seu agente toma para si um monopólio institucional. Com isso se dá a lógica de ação de grupos, como não há uma alternativa institucional interna ao próprio movimento que possa exercer o papel de controle por parte dos próprios assentados.

Nesse sentido, ao considerar a ação política como parte da ação empreendedora no sentido da defesa de uma categoria, deve-se compreender um ponto fundamental de sua formação. Por ser uma ação política originada na organização, ao coordenar as atividades produtivas, comerciais e financeiras ela se delimita ao escopo de ação institucional.

A consecução de uma ação política que tenha um sentido revolucionário passa a se tornar uma extravagância da gestão. A esse exemplo, trata-se aqui de tentativas de imprimir uma transformação em qualquer uma das atividades da organização associativa como uma diferente forma de produzir, de comercializar, de financiar ou de representar. Dessa maneira, conforma-se uma disposição das interações de forma a radicalizar as posições das diferenças entre seus membros, de forma a transpor uma relação de poder político sobre uma diferença de poder no mercado, sendo necessário, na atuação da agricultura política moderna, compreender as diferenças entre as categorias distintas da lógica da atuação entre essas duas expressões do poder.

\subsection{AS CONDIÇÕES DA ATUAÇÃO ENTRE COPAVA E A COAPRI}

Do ponto de vista legal a Copava e a Coapri são cooperativas equivalentes; a rigor, correspondem legalmente da mesma maneira. Assim, por terem a mesma posição de mercado, constituem entre si uma relação concorrencial.

Porém, tomado o Sistema de Cooperativas de Assentados (SCA), elas teriam uma diferença, dada a reserva de complementariedade: uma teria estritamente o papel da organização da produção e a outra estritamente o papel da comercialização e do oferecimento de serviços agrícolas. 
Contudo, ainda que do ponto de vista da idealização desse plano elas teriam funções distintas, na realidade não interagem dessa forma. Complementam-se em funções específicas, assim como poderia ocorrer entre qualquer outro tipo de ente ou organização política.

A ideia da relação complementar entre ambas só é possível por um imperativo político externo a elas, no sentido de que, na busca da correspondência de seus objetivos econômicos, não há uma necessidade especial da manutenção de suas relações.

A estratégia de distinção do papel da organização dessas cooperativas corresponde à formação de uma burocracia que detém um papel técnico-administrativo, que destacado do trabalho direto com a produção, é o mesmo. Isso é ainda mais claro quando se observa o acesso ao mercado institucional.

Como os programas preveem a comercialização de produtos por meio de associações ou cooperativas, dentro do mercado do assentamento não há diferença entre acessar uma ou outra. Da mesma maneira se observa uma autonomia por parte da Copava em realizar ela mesma ou substituir a atividade da Coapri quanto aos seus serviços.

\subsection{O PROBLEMA DA TRANSFERENNCIA DOS LOTES}

No âmbito produtivo e de titularidade do lote, há um problema da concepção da unidade familiar. Só se pode passar para um filho, não necessariamente o primogênito. Assim, além do primeiro, ou daquele que recebe a terra, os outros foram procurando novas terras para a sua exploração econômica, daí a expansão do assentamento.

Entretanto, nota-se que a mudança demográfica acabou por mitigar a disputa dentro da família pela hereditariedade, pois há menos filhos e há uma emigração do assentamento pela busca por outras carreiras no assentamento. A configuração institucional da transferência de titularidade não corresponde à dinâmica demográfica da unidade familiar ligada à terra.

Em todo o assentamento existem laços de parentesco, inclusive com os das áreas emergenciais. Assim, a ideia da incorporação de terras a partir da transferência de lotes entre familiares, dada a diferença do módulo rural —lotes de áreas mais recentes são 
menores que os mais antigos-, é um potencial elemento de associação familiar que pode induzir a novas organizações produtivas associativas.

Segundo um dos agentes que atua no assentamento, o meio de intervenção técnica para a inovação não pode ser feito com base em um plano idealizado pelo técnico, mas a partir da demonstração de uma experiência bem-sucedida. Nesse ponto, o que fica claro é a concepção por parte do técnico de que a intervenção é uma correção. Na explicação sobre a diferença da intervenção é isso que é suposto no discurso da falta de ajuda, mesmo com o projeto via heterogestão. 


\section{CONSIDERAÇÕES FINAIS}

A configuração das estruturas em organizações associativas, como as cooperativas, sofre influência tanto da maneira da ação coletiva que a funda, como de outras possíveis organizações ou movimentos que atuem diante de seu corpo de membros e, a partir de um ponto de vista econômico, clientes. Efeitos sobre as estruturas de governança são observados, sobretudo quando as organizações tomam contato com os membros dessa associação no sentido de instituir uma intervenção agrária, dado o caso estudado.

A estrutura de governança das associações cooperativas é de menor -ou nenhuma- relevância nas interações sociais presentes às quais se dá o papel econômico dos seus agentes. Porém, o reconhecimento de sua representação feito por uma terceira parte implica a colocação do primeiro problema comunitário de ação coletiva, no sentido de incentivar e organizar suas relações. Assim, como instituições intermediárias das interações, só pode se dar por meio e a partir da existência de uma organização que as realize.

A transação fundamental acarreta a troca da produção por meios monetários. Essa transação é a que representa a contradição de interesses entre os dois lados da sua realização. Nesse sentido, o que se pode compreender é que ela estabelece uma fronteira na qual há o elemento comunitário e o extracomunitário como detentores de interesses contraditórios e que é a partir desta que se observa a caracterização nas potenciais cadeias de comercialização o interesse contraditório.

Um ponto a ser observado em pesquisas posteriores é o da natureza da mobilização inicial, quanto às consecuções de seus objetivos por meio da violência, como no caso das ocupações de terra. Assim, como no caso dos movimentos cooperativistas do século XIX - precedidos por movimentos derrotados que apelaram ao uso da violência para defender interesses que não eram representados ou reconhecidos-, o estudo aponta para uma possibilidade desse tipo de desenvolvimento por esse tipo de movimento, atualmente.

A promoção do cooperativismo, focalizando a formação da organização em seu sentido de orientação política, acaba desprovendo-se de meios de rearranjo e concerto 
diante de diferenças e disputas quanto às atividades e aos objetivos da associação formada. Uma vez constituído um quadro de membros dirigentes da organização política, ele acaba incidindo na relação dos membros da cooperativa em suas instâncias de decisão. A observação desse fenômeno até o estabelecimento de um grupo que se mantém leal à organização diante de grupos que dissidiam dela e saem, ainda deve ser estudada, pois requer a análise do fator temporal com maior amplitude do que com o que foi feito neste estudo.

Uma das questões que pode apontar para o fato dessa impossibilidade é o fato de que, uma vez constituída uma organização, dentro da associação, com a função da mobilização para o uso da violência, como no caso da sua formação, ela acaba desconhecendo os interesses alheios a si. Dessa forma, o equilíbrio da balança de poder da relação entre os integrantes suspende a condição para a negociação de interesses.

A intervenção agrária é um problema que, ao contrário do que se suporia, não é estrito a organizações política, mas sim ao problema da heterogestão. De fato, órgãos públicos ou empresas privadas também se veem colocados sob o mesmo desafio, pois a concepção teórica de agribusiness é concebida a partir de uma orientação baseada na heterogestão.

A adaptação das atividades das associações cooperativas pode ter uma relação com a compreensão da sua estratégia enquanto organização. Burocracias são por excelência organizações responsáveis pelo planejamento das organizações, conforme a concepção de Galbraith, e nesse sentido acabam relegando um papel distinto na coordenação da produção dos diferentes agentes produtivos.

Outro aspecto dessa intervenção, no sentido de promover a formação de cooperativas, mas que são empreendidas pelo setor público ou por setor privado, como no caso das organizações não governamentais, é o fato de se conceber a formação dessa organização como uma forma de prevenção à pobreza. Nesse caso, observa-se que esse incentivo pode ter problemas de operação por conta do não entendimento da dinâmica familiar da agricultura.

As mobilizações de cunho social e político externos às cooperativas continuam tendo o papel de impulsionadoras de inovações. Nesse ponto, cabe observar que propostas de novas produções, comércio, marketing, assim como outras formas de 
organização, podem existir a partir de uma procura individual familiar por essas inovações. Porém, estas tendem a ser concebidas dentro de convenções estabelecidas, conhecidas ou transmitidas por outras experiências já estabelecidas, replicadas por eles. Inovações de maior amplitude são, em geral, levadas por organizações não familiares. Com isso, pode-se dizer que as famílias tendem a inovar por conta própria no âmbito da produção. Em relação a novos métodos gestão e comercialização, elas acabam por receber propostas de outras organizações.

No caso mesmo da intervenção pela promoção de organizações cooperativas, do ponto de vista estratégico a observação feita por Pedro Ivan Christoffoli aponta para essa direção - de que de fato, a tentativa de impor um determinado tipo de arranjo como um modelo é equivocada e não apresenta resultados que se sustentem ao longo do tempo. Suas afirmações sobre as cooperativas de inspiração do MST, as CPAs, quanto à insustentabilidade se confirmaram, como no caso das experiências em Pirituba II.

A família tende a ser a organização social de maior importância no constrangimento dos atores individuais na interação social feita com fins econômicos. Ainda que, por questões de implicação técnica, seu papel no campo produtivo tenha sido bastante reduzido, o que se pode observar é que há uma cumplicidade necessária capaz de manter o domínio fundiário enquanto agente da produção condicionante da atividade agrícola.

O tamanho das organizações é relevante quanto ao desempenho econômico, na medida em que há uma relativização da importância de cada família individualmente. Cabe observar que, ao tomarmos o tema do funcionamento das atividades da cooperativa, o que se pode notar é que, de fato, quanto maior o número de diferentes famílias membros da cooperativa, menor relevância terá a contradição de interesses representados pelos núcleos familiares. A contradição dos interesses negociados e representados tende a ser de outra ordem.

Estrategicamente, o que se pode considerar a partir dos resultados deste presente estudo, é que a adequação do arranjo cooperativo aos seus membros está relacionada com a sua situação de mercado e de classe. Assim, assentamentos que contenham organizações com diferentes formas de estruturação do seu capital têm a potencialidade 
de absorver ou dar autonomia às famílias em diferentes momentos do cenário econômico vivido.

De qualquer maneira, se a formação de cooperativas é incentivada a fim de diminuir os custos de transação com a formação de mercados institucionais para compras públicas, a legislação prevista ao amparo legal do funcionamento dessas associações e cooperativas acaba aumentando esses custos. Os arranjos possíveis dentre os grupos nessas organizações acabam sendo limitados quanto a sua configuração.

As relações de poder em organizações cooperativas extrapolam a visão de que essas relações funcionam sob a dinâmica do mercado. De fato, em relação a operações da produção e relações de troca, pode corresponder circunstancialmente a essa dinâmica, mas a associação, as alianças e coalizões tratam de conformar relações profundas de pertencimento e de participação, dadas as experiências dificultosas da trajetória dos seus membros.

A condição de mercado ou de classe dos sujeitos em um determinado momento pode facilitar ou propiciar a sua associação. Os recursos disponíveis e as fontes de seu poder podem apenas teoricamente conformar um equivalente à ideia de estrutura de mercado. Isso se dá pelo fato de que o ato político, no caso também de uma ação coletiva, pode ser concebido fora de qualquer ideia de mercado, já que a interpretação de seus ganhos e custos pode em nada corresponder a essa dinâmica concorrencial observada no comportamento no mercado, considerando que em última instância se trata de uma contradição entre organizações em sua capacidade de promover seus interesses e impor suas decisões.

As observações a respeito das experiências associativas observadas apontam para o fato da existência de uma relação com a natureza política da organização existente no momento da coordenação da ação coletiva para a sua formação. Mobilizações que têm por objetivos questões diretamente ligadas à sua vida cotidiana diferem em relação a grupos com a mobilização de orientação sindical ou partidária.

Essa relação também se observa quanto às estratégias concebidas para a manutenção da cooperativa. No caso de grupos com um maior peso na mobilização política, ou em que essa mobilização política se mantém, nota-se uma tendência a conceber e empreender estratégias de integração vertical. Isso se dá pelo fato de que a 
organização política se inclina a instituir uma relação econômica que reproduza a sua constituição hierárquica, como no caso de burocracias sindicais ou partidárias.

A questão da organização da cooperativa como uma derivação representante de um agregado de unidades permite-nos constatar que a cooperativa é uma organização derivada que supera o ambiente doméstico da relação social de produção. Nesse sentido, o que podemos compreender é que a concepção chayanoviana da agricultura familiar explica a dinâmica de como se dão as formas de reprodução social e de apropriação através da unidade familiar.

Entretanto, ao compreender a formação da teoria da cooperativa camponesa, observa-se que, dada a incorporação de categorias econômicas modernas, o que se pode notar é que, do ponto de vista da barganha entre as famílias, o que há é a expansão da apropriação doméstica dessa estrutura familiar. É a associação de unidades familiares, cada qual mantendo o seu espaço doméstico que é capaz de conformar a cooperativa.

Como outros estudos apontam, a proposta, ou transição agroecológica, é tecnicamente possível, porém, equivocada na sua concepção de relações entre os produtores e os externos. A apropriação da proposta agroecológica se dá com a finalidade de transformá-la em uma arma política pelo MST.

Superar o domínio de grandes corporações do agronegócio, com base em aportes tecnológicos e capital, através de uma produção que não dependa de ingressos que destes provenham ocorreria por meio da intensificação do trabalho como fator de produção, concebido como a vantagem dos pequenos produtores diante dessas corporações. Porém, como a teoria chayanoviana demonstra, essa concepção é inviabilizada pelo mecanismo de regulação da autoexploração do trabalho agrícola pelo camponês, ou no nosso caso o produtor, que impede tal esforço por parte deste tendo em vista que a troca mercantil de tal produção não é feita em volumes monetários correspondentes que sustentem tal intensificação, uma situação que pode se manter mesmo quando há demanda.

O reconhecimento da agroecologia enquanto meio alternativo de produção não tem opositores por princípios sanitários ou ecológicos. Contudo, apesar de uma eventual simpatia dos produtores pela proposta, ela é percebida como um meio de produção com 
riscos elevados, não por não ser tão produtiva quanto a convencional, mas por estar sujeita a perdas cujos instrumentos de intervenção para a sua diminuição são limitados.

A caracterização da barganha nas interações entre os agentes sociais é um elemento que indica a conformação do sentido destas que podem ser competitivas ou não competitivas. Assim, os elementos que configuram essa caracterização acabam sendo os de poder real, utilizados pelos agentes a fim de conseguir uma resolução favorável à busca por seus próprios interesses.

Assim, ao observarmos a questões de decisão e ação coletiva tomada a partir de questões referentes à mudança institucional, observamos que há questões de representação em relação aos membros familiares, de subordinação a regras específicas, além de como conformar as transações externas, que se põem como problemas centrais. O elemento de barganha entre as famílias dentro dessa representação passa a ser uma forma de apropriação de uma unidade familiar em relação aos recursos das outras unidades, não havendo nisso uma diferenciação técnica de funções, mas apenas uma disputa que se desenvolve em meio aos usos dos mecanismos de representação e da sua participação na estrutura de capital da organização representada pela cooperativa.

A gênese de uma firma cooperativa, em que os foros de decisão são, em alguma medida, coletivos, implica a formação de grupos de interesse que se opõem a essas decisões. Assim, pode haver a apropriação dos recursos e ativos disponíveis na organização ou pode haver uma consideração outra diante da intermediação de terceiros na relação entre as famílias. Nesse sentido, o que se pode compreender é que há a formação de uma oligarquia dentro dessas organizações cooperativistas.

A relativa facilidade com que se consegue abrir uma cooperativa, tendo em vista que a expansão do núcleo familiar por meio de relações de parentesco que se deu com a incorporação de novas áreas para o assentamento faz com que a cooperativa se torne, então, uma forma de empreendimento familiar com vias a tomar para si mercados institucionais que têm para a comercialização o requisito de que seja realizada através de cooperativas. Assim, as associações e cooperativas do assentamento em que a relação de parentesco seja mais frágil, ou inexistente, entre seus membros, se enfraquecer e percam capacidade de atrair novos membros ou manter os que já nela estão. 
Por isso, a concepção de Emelianoff de que basicamente a cooperativa se dá por uma derivação do agregado de unidades produtivas representadas por ela, acaba tendo uma conotação distinta, quando a família e seus diferentes membros, acabam de alguma maneira incorporando essa unidade de produção. É a transposição do nível doméstico familiar da produção ao nível coletivo que leva a esses conflitos.

Porém, o grupo que dirige a cooperativa passa por situações nas quais consegue elementos para barrar o poder de influência das famílias e manter um objetivo que implique a coordenação das ações e na promoção das interações. Assim, é diante da relação com os elementos constituintes da barganha que se segue à dinâmica das trocas, nas quais há o desenvolvimento da reciprocidade que transforma o sentido das interações entre os agentes representantes do agregado, em que não apenas a barganha não é cooperativa, mas a dinâmica da reciprocidade que se desenvolve de forma hostil.

Essa dinâmica de reciprocidade hostil pode se gravar, como observado no estudo, diante da fraqueza da posição de mercado da representação da cooperativa, mesmo quando ela ainda detém um acesso a um mercado exclusivo, como no caso dos mercados institucionais de compras públicas. Nesse ponto, ao contrário de procurar capturar renda nas transações operadas com externos, ela acaba capturando renda dos seus próprios membros, diante da sua própria necessidade de financiamento. Isso deteriora a relação de reciprocidade que acaba refletida na comercialização de outros produtos, como no caso commodities fora dos mercados institucionais.

Nesse caso, o grupo passa a depender de fontes de poder outras que não a de uma simples coalização familiar. O papel da personalidade de determinados líderes é importante, ainda que se possa considerar efêmero. No caso da fonte de poder da organização - e aqui o papel de organizações não governamentais e movimentos sociais surge-, ela, potencialmente, pode dotar esse grupo de tal elemento de poder por um período maior, ainda que as relações entre esse grupo. Porém, como observado, se este grupo for dotado de uma organização que desequilibre a relação de poder entre as famílias e ele, a possibilidade de não reconhecimento de interesses acaba retirando a relação de um espaço de negociação e levando ao conflito. 


\section{REFERÊNCIAS ${ }^{27}$}

Alves-Mazzotti, A. J. (2006). Usos e abusos dos estudos de caso. Cadernos de Pesquisa, 36(129), 637-651. http://doi.org/10.1590/S0100-15742006000300007

Alves Sobrinho, F. F. (2008). A Extensão Rural na Fundação ITESP: Caminhos e descaminhos do ensino aprendizagem. Unicamp.

Andrade, T., \& Pereira, C. A. C. (Orgs.). (2000). Mediação no Campo: Estratégias de ação em situações de conflito fundiário. São Paulo: Editora Gráfica.

Anton, S. (2011). From Food Security to Food Sovereignty: The Fome Zero Food Acquisition Program in the Pontal do Paranapanema, Brazil. Simon Fraser University.

Aoki, M. (2007). Endogenizing institutions and institutional change. Journal of Institutional Economics, (3), 1-31.

Araújo, S. M. P. (1982). Eles, a Cooperativa: Estudo sobre a ideologia da participação. Indústria Gráfica Projeto.

Barretto, N. R. (2004). Reforma Agrária: Mito ou Realidade? (4ºd). São Paulo: Artpress Indústria Gráfica e Editora Ltda.

Barros, C. P., Araujo Jr., A. F. de, \& Faria, J. R. (2013). Brazilian land tenure and conflicts: The landless peasants movement. CATO Journal, 33(1), 47-75. Recuperado de http://search.ebscohost.com/login.aspx?direct=true\&db=aph\&AN=85491855\&site $=$ ehost-live

Bialoskorski Neto, S. (1998). Ensaios em cooperativismo. Ribeirão Preto.

Bialoskorski Neto, S. (2000). Politica Institucional de Monitoramento de Autogestão das Cooperativas do Estado de São Paulo: uma proposta de metodologia, pesquisa e manual de implantação. FAPESP.

\footnotetext{
${ }^{27} 1$ De acordo com a Associação Brasileira de Normas Técnicas (ABNT NBR 6023).
} 
Bombardi, L. M. (2005). Campesinato, luta de classe e reforma agrária (A Lei de Revisão Agrária em São Paulo). São Paulo, 2005. Tese (Doutorado em Geografia Humana). Departamento de Geografia, Faculdade de Filosofia, Letras e Ciências, Universidade de São Paulo. Universidade de São Paulo.

Bourgholtzer, F. (1999). Aleksandr Chayanov and Russian Berlin. In T. J. Byres Aleksandr Chayanov and Russian Berlin. Midsomer Norton: Bookcraft Ltd. Recuperado

de https://books.google.com.br/books?id=auyG1 kjPwYC\&pg=PA16\&lpg=PA16\&dq $=$ linen + centre + russia\&source $=$ bl\&ots $=$ NxaLsMBEuj\&sig=4F0d6biTTWMaD2km 2Pqzyvuh2 M\&hl=pt-

Brasil. Lei No .5. 994

Câmara, S. F., Mota, M. de O., Marques, G. O., \& Spinosa, L. S. (2016). Dualidade de práticas gerenciais e político-sociais em cooperativas de reforma agrária ligadas ao Movimento dos Trabalhadores Rurais Sem Terra (MST). Estudos Sociedade e Agricultura, 2(24), 417-443.

Camargo, L. C. (1960). Cooperação e Cooperativismo. São Paulo.

Carvalho, P. A. F. de. (2014). Biografia sumária de Chayanov. In H. M. de Carvalho (Org.), Chayanov e o Campesinato ( $1^{\circ}$ ed, p. 33-38). São Paulo: Expressão Popular.

Carvalho, Y. M. C. de, \& Dulley, R. D. (1994). Modelo de gestão do assentamento Pirituba I Área II no Estado de São Paulo. Agricultura em São Paulo, 41(1), 2132.

Caume, D. J. (2002). A Tessitura do “Assentamento de Reforma Agrária”. Discursos e práticas instituintes de um espaço agenciado pelo poder. Tese de doutorado em ciências Sociais. Unicamp/IFCH.

Çelikten, M. (2014). Land Struggle and beyond: Landless Rural Workers' Movement of Brazil. Middle East Technical University. Recuperado de Master

Chacon, V. (1959). Cooperativismo e comunitarismo: Estudo de Organização sócioeconômica. Revista Brasileira de Estudos Políticos. Rio de Janeiro: Imprensa da 
Universidade de Minas Gerais.

Chayanov, A. V. (2014). A Teoria dos sistemas não-capitalistas. In H. M. de Carvalho (Org.), Chayanov e o Campesinato $\left(1^{\mathrm{a}}\right)$. São Paulo: Editora Expressão Popular.

Christoffoli, P. I. (2000). O Desenvolvimento de cooperativas de produção coletiva de trabalhadores rurais no capitalismo: Limites e possibilidades. Dissertação de Mestrado. Curitiba. Universidade Federal do Paraná.

Christoffoli, P. I. (2015). Elementos introdutórios para uma história do cooperativismo e associativismo rurais no Brasil. In: Novaes; Mazin; Santos. Questão agrária, cooperação e agroecologia. 1ed. São Paulo: Outras Expressões, 2015, v. 1, p. 169188.

Coase, R. H. (1960). O problema do custo social. Journal of Law and Economics, 1-37. Recuperado de http://services.bepress.com/lacjls/vol3/iss1/art9/

Costa, C. M. O. da, \& Bergamasco, S. M. P. P. (2003). Processo de organização da produção em assentamentos rurais no Brasil: A fazenda Pirituba/SP. In S. M. P. P. Bergamasco, M. Aubrée, \& V. L. S. B. Ferrante, Dinâmicas Familiar, Produtiva e Cultural nos Assentamentos Rurais de São Paulo (p. 125-155). Araraquara: INCRA.

Creswell, J. W. (2003). A Framework for design. In Research design qualitative quantitative and mixed methods approaches. Thousand Oaks, London, and New Delhi: SAGE Publications. http://doi.org/10.3109/08941939.2012.723954

Creswell, J. W. (2007). Projeto de pesquisa ( $2^{\circ}$ ed). Porto Alegre: Artmed.

Creswell, J. W., \& Plano Clark, V. I. (2013). Pesquisa de métodos mistos (2 ${ }^{\mathrm{o}}$ ed). Porto Alegre: Editora Penso.

Crozier, M. (1981). O Fenômeno burocrático ( $1^{\circ}$ ed). Brasília: Universidade de Brasília.

Crúzio, H. de O. (1999). Por que as cooperativas agropecuárias e agroindustriais brasileiras estão falindo? RAE - Revista de Administração de Empresas, 39(2), 1826. 
Decreto $N^{o}$ 59.456, de 4 de Novembro de 1966 (1966). Aprova os planos Nacional e Regionais de Reforma agrária e dá outras providências. Brasília, DF. Recuperado em 3 de agosto de 2017, de: http://www2.camara.leg.br/legin/fed/decret/1960-1969/decreto59456-4-novembro-1966-399970-publicacaooriginal-38471-pe.html

Decreto $N^{o}$ 91.766, de 10 de Outubro de 1985 (1985). Aprova o Plano Nacional de Reforma Agrária - PNRA, e dá outras providências. Brasília, DF. Recuperado em 3 de agosto de 2017, de: http://www2.camara.leg.br/legin/fed/decret/1980-1987/decreto91766-10-outubro-1985-441738-publicacaooriginal-1-pe.html

Decreto $N^{o} 3.338$, de Janeiro de 2000 (2000). Aprova a Estrutura Regimental e o Quadro Demonstrativo dos Cargos em Comissão e Funções Gratificadas do Ministério do Desenvolvimento Agrário, e dá outras providências. Brasília, DF. Recuperado em 3 de agosto de 2017, de: http://www.planalto.gov.br/ccivil_03/decreto/D3338.htm

Decreto-Lei $N^{o} 1.110$, de 9 de julho de 1970 (1970). Cria o Instituo Nacional de Colonização e Reforma Agrária, o Instituto Nacional de Desenvolvimento Agrário e o Grupo Executivo da Reforma Agrária e dá outras providências. Brasília, DF. Recuperado em 3 de agosto de 2017, de: http://www.planalto.gov.br/ccivil_03/decreto$\underline{\text { lei/1965-1988/Del1110.htm }}$

Dequech, D. (2007). Neoclassical, mainstream, orthodox, and heterodox economics. Journal of Post Keynesian Economics, 30(2), 279-302.

Diniz, A. S., \& Gilbert, B. (2013). Socialist values and cooperation in Brazil's Landless Rural Workers' Movement. Latin American Perspectives, 40(4), 19-34. http://doi.org/10.1177/0094582x13484290.

(Disoc/Ipea), C. de D. R. (2013). Avaliação da situação de assentamentos da reforma agrária no estado de São Paulo: Fatores de Sucesso ou Insucesso. Brasília

Emelianoff, I. V. (1995). Economic theory of cooperation: Economic structure of cooperative organizations. Recuperado de http://sfp.ucdavis.edu/files/143756.pdf

Favareto, A. (2007). Plano Territorial de Desenvolvimento Rural Sustentável Sudoeste $\begin{array}{lll}\text { Paulista } & (S P) \text { Recuperado de }\end{array}$ http://sit.mda.gov.br/download/ptdrs/ptdrs_qua_territorio012.pdf.

Fernandes, B. M. ([s.d.]). Land reform in the Brazilian governments of presidents 
cardoso and lula: challenges for agrarian geography. Recuperado de https://www.researchgate.net/publication/238680015_Land_Reform_in_the_Brazil ian_Governments_of_Presidents_Cardoso_and_Lula_Challenges_for_Agrarian_G eography

Fernandes, B. M. (1994). Especialização e Territorialização da Luta Pela Terra: A Formação do MST - Movimento dos Trabalhadores Rurais Sem Terra no Estado de São Paulo. Dissertação de Mestrado. Recuperado de http://www2.fct.unesp.br/nera/ltd/Dissertacao_BMF.pdf

Fernandes, B. M. (1999). Contribuição ao Estudo do Campesinato Brasileiro Formação e Territorialização do Movimento dos Trabalhadores Rurais Sem Terra - MST (1979-1999). Recuperado de http://www2.fct.unesp.br/docentes/geo/bernardo/BIBLIOGRAFIA\%20DISCIPLIN AS\%20POS-

GRADUACAO/BERNARDO\%20MANCANO\%20FERNANDES/tese_bmfernan des.pdf

Fernandes, B. M., Welch, C. A., \& Gonçalves, E. C. (2012). Land governance in Brazil. A geo-historical review of land governance in Brazil. Recuperado de

http://www.landcoalition.org/sites/default/files/documents/resources/FramingtheDebate Brazil.pdf

Flick, U. (2009). An Introduction to qualitative research. http://doi.org/978-1-84787$323-1$

Gala, P. S.O.S. (2001). Teoria e Retórica em Douglass North: Subsidios para uma análise de sua contribuição. Recuperado de

http://bibliotecadigital.fgv.br/dspace/bitstream/handle/10438/1819/1200102990.pdf?seq uence $=1$

Gala, P. (2003). A Teoria institucional de Douglas North. Revista de Economia Política, 23(2), 89-105.

Galbraith, J. K. (1986). Anatomia do poder ( $2^{\circ}$ ed). São Paulo: Editora Pioneira.

Gibson-Graham, J. K. (2003). Enabling Ethical Economies: Cooperativism and Class. 
Critical Sociology, 29(2), 123-161. https://doi.org/10.1163/156916303769155788

Gilbert, B. (2006). Workers' Power and Socialism: A Study of Brazil's Movement of Landless Workers. Situations: Project of Radical Imagination, 1(2), 73-86.

Hegenberg, L. (1985). Notas sobre questões de metodologia e a ciência econômica. Revista Brasileira de Economia, 39(2), 207-216.

Hirschman, A. O. (1973). Saída, voz e lealdade. Reações ao declínio de firmas, organizações e estados. São Paulo: Editora Perspectiva S.A.

Hodgson, G. M. (2013). From Pleasure Machines to Moral Communities - An Evolutionary Economics Without Homo economicus. Chicago and London: The University of Chicago Press. http://doi.org/10.1017/CBO9781107415324.004

Hodgson, G. M. (2015). Conceptualizing Capitalism. Institutions, Evolution, Future. Chicago and London: The University of Chicago Press.

Iokoi, Z. M. G., Andrade, M. R. de O., Rezende, S., \& Ribeiro, S. (Orgs.). (2005). Vozes da Terra: Histórias da vida dos assentamentos rurais de São Paulo. São Paulo: Fundação Instituto de Terras do Estado de São Paulo José Gomes da Silva.

Kagarlitskii, Y. I. (1990). Aleksandr Chaianov: Utopographer and romantic. Slavic Review, 49(4), 634-642.

Kojima, S. (2004). Comparing Chayanov and Kondratiev: Two Russian economists in the 1920's. Japanese Slavic and East European Studies, 25, 1-25.

Kröger, M. (2010). The politics of pulp investment and the Brazilian Landless Movement (MST). (Department of Political and Economic Studies, Org.), Acta Politica. Helsinki: University of Helsinki.

Landertinger, L. (2009). Brazil's Landless Workers Movement (MST), (July). Recuperado de http://www.yorku.ca/cerlac/documents/Landertinger.pdf

Lei Estadual $N^{o} 5.994$ de 30 de dezembro de 1960 (1960). Estabelece normas de estímulo à exploração racional e econômica da propriedade rural e dá outras providências. São Paulo, SP. Recuperado em 3 de agosto de 2017, de: http://www.al.sp.gov.br/repositorio/legislacao/lei/1960/lei-5994-30.12.1960.html 
Lei $N^{o} 4.504$, de 30 de novembro de 1964 (1964). Dispõe sobre o Estatuto da Terra e dá outras providências. Brasília, DF. Recuperado em 3 de agosto de 2017, de: http://www.planalto.gov.br/ccivil_03/leis/L4504.htm

Lopes, M. de R. (1996). Agricultura Política. Brasília: EMBRAPA.

Loureiro, M. R. G. (1981). Cooperativismo e reprodução camponesa. In M. R. G. Loureiro (Org.), Cooperativas agrícolas e capitalismo no Brasil. São Paulo: Cortez Editora.

Love, J. L. (1990). Theorizing Under development: Latin America and Romania, 18601950*.

Love, J. L. (1996). Crafting the Third World: Theorizing Underdevelopment in Rumania and Brazil. Stanford: Stanford University Press.

Love, J. L. (2009a). Late Agrarianism in Brazil : Kautsky and Chayanov in the 1970s, (1899), 1-26.

Martins, J. de S. (1999). Reforma agrária: O impossível diálogo sobre a História possível. Tempo Social: Revista de Sociologia. 11(2)97-128.

Mason, J. (2002). Qualitative Researching ( $2^{\circ}$ ed). London, Thousand Oaks, and New Delhi: SAGE Publications.

McKenna, L. M. (2004). The MST and the myth of Brazilian land reform. Anamesa: an interdiscplinary journa: The Myth Issue, 2(2), 19-37.

Meek, D. D. (2011). Propaganda, collective participation and the "war of position" in the Brazilian Landless Workers' Movement. Studies in the Education of Adults, 43(2), 164-181.

Meek, D. D. (2014). Movements in Education: The political ecology of education in the Brazilian Landless Workers' Movement. Recuperado de http://www.tandfonline.com/doi/full/10.1080/13504622.2014.933778

Moraes, R. C. C. de, \& Coletti, C. (2006). MST, o radicalismo agrário em busca de um mundo novo... possível? In R. C. C. de Moraes, Globalização e Radicalismo Agrário (p. 91-115). São Paulo: Editora UNESP. 
Morais, C. S. de. (1986). Caderno de Formação $n^{0} 11$ : Elementos sobre a teoria da organização no campo. Recuperado de http://docvirt.com/docreader.net/DocReader.aspx?bib=bibliotlt\&pagfis=3330

Motta, F. C. P. (1982). Participação e Co-Gestão. Novas formas de administração. São Paulo: Editora Brasiliense.

Navarro, Z. (2015). História concisa da agricultura brasileira: Do pós-guerra aos nossos dias. In X. Graziano \& Z. Navarro, Novo Mundo Rural. São Paulo: Editora UNESP.

North, D. C. (1993). The New Institutional Economics and Development. Recuperado de http://econwpa.repec.org/eps/eh/papers/9309/9309002.pdf

Oberg, K. (1965). The marginal peasant in rural Brazil. American Antropologist, 67(6, part 1), 1417-1427.

Oliveira, A. U. De. (2007). Modo de produção capitalista, agricultura e reforma agrária $\left(1^{\mathrm{o}}\right.$ ed). São Paulo: FFLCH/ Labur Edições.

Olson, M. (2002). The Logic of Collective Action: Public Goods and the Theory of Groups. Contemporary Sociological Theory, Blackwell, Oxford. https://doi.org/10.2307/2576430

Ondetti, G. (2008). Land, protest, and politics: The Landless Movement and the struggle for agrarian reform in Brazil. University Park: The Pennsylvania State University Press. http://doi.org/10.1111/j.1471-0366.2010.00292.x

Osborne, M. J., \& Rubinstein, A. (2005). Bargaining and markets. San Diego and London: Academic Press Inc.

Ostrom, E. C. (1998). A behavioral approach to the rational choice: Presidential address, American political science association, 1997. American Political Science Review, 92(1), 1-22.

Ostrom, E. C. (2007). Developing a method for analyzing institutional change. conflict. Recuperado de http://papers.ssrn.com/sol3/papers.cfm?abstract_id=997837

Pahnke, A. R., Tarlau, R., \& Wolford, W. (2015). Understanding rural resistance: 
contemporary mobilization in the Brazilian countryside. The Journal of Peasant Studies, 42(6), 1069-1085. http://doi.org/10.1080/03066150.2015.1046447

Pedon, N. R. (2013). Geografia e movimentos sociais: dos primeiros estudos à abordagem socioterritorial. São Paulo: Editora UNESP.

Petschulat, G. (2010). Grass-roots struggle in the "culture of silence ": Collective dialogue and the Brazilian Landless Movement. Recuperado de http://trace.tennessee.edu/cgi/viewcontent.cgi?article $=2384 \&$ context $=$ utk chanhon oproj

Pilla, M., Andrade, M. R. de O., \& Marques, L. A. de P. (Orgs.). (2013). Fundação ITESP: sua história e realizações. Evolução das políticas agrária, e fundiária no estado de São Paulo. São Paulo: ITESP.

Pinho, D. B. (1961). O Cooperativismo nos meios capitalista e socialista, suas modificações e sua utilidade. São Paulo: F.F.C.L.H.

Pinho, D. B. (2007). As Cooperativas no Desenvolvimento do Brasil: Passado, Presente e Futuro: tentativa de sintese. Santo André: ESETec.

Plummer, D. M. (2008). Leadership development and formação in Brazil's Landless Workers Movement (MST). The City University of New York. Recuperado de http://www.mstbrazil.org/files/Leadership Development and Formação in MST.pdf

Polanyi, K. (2000). A Grande transformação:- as origens de nossa época. Rio de Janeiro: Editora Campus.

Portela, F., \& Fernandes, B. M. (2008). Reforma Agrária (13º ed). São Paulo: Editora Ática.

Queiroz, M. I. P. de. (1991). Variações sobre a técnica de gravador no registro da informação viva. São Paulo: T. A. Queiroz Editor Ltda.

Ramos, A. G. (1989). A nova ciência das organizações: uma reconceituação da riqueza das nações ( $2^{\circ}$ ed). Rio de Janeiro: Fundação Getúlio Vargas.

Raskov, D. (2014). Socialist agrarian utopia in the 1920's: Chayanov. Oeconomia, 
4(2), 123-146. Recuperado de https://oeconomia.revues.org/836\#bodyftn3

Robles, W. (2001). The Landless Rural Workers Movement (MST) in Brazil. Journal of Peasant Studies, 28(2), 146-161. http://doi.org/10.1353/lar.2010.0032

Sabourin, E. P. (2009). Camponeses do Brasil: entre a troca mercantil e a reciprocidade. Rio de Janeiro: Garamond Universitária. Recuperado de http://books.google.com/books?id=-KEnAQAAIAAJ\&pgis=1

Sabourin, E. P. (2010). Manejo dos recursos comuns e reciprocidade: Os aportes de Elinor Ostrom ao Debate. Sustentabilidade em debate, (July), 143-158. Recuperado de http://periodicos.bce.unb.br/index.php/sust/article/view/1689

Sabourin, E. P. (2011). Teoria da reciprocidade e sócio-antropologia do desenvolvimento. Sociologias, 13(27), 24-51. http://doi.org/10.1590/S151745222011000200003

Sabourin, E. P. (2013). Comercialização dos produtos agrícolas e reciprocidade no Brasil. Estudos Sociedade e Agricultura, 21(1), 5-33.

Silva, J. G. da. (1996). A Nova Dinâmica da Agricultura Brasileira. Campinas: UNICAMP.

Shimbo, J. Z., \& Jiménez-Rueda, J. R. (2007). Zoneamento geoambiental como subsídio aos projetos de reforma agrária. Estudo de caso: assentamento rural Pirituba II (SP). NERA, (10), 115-133.

Simões, A. (2014). Instituições e desenvolvimento econômico: os contrastes entre as visões da Nova Economia Institucional e dos Neo-Institucionalistas. Ensaios FEE, 35(1), 33-54. Recuperado de http://revistas.fee.tche.br/index.php/ensaios/article/view/2900

Sinek, W. M. (2007). Coalitional choices and strategic challenges: The Landless Movement in Brazil, 1970-2005. Recuperado de http://escholarship.org/uc/item/7q5402w4\#page-3

Sobreiro Filho, J. (2013). O Movimento em pedaços e os pedaços em movimento: da ocupação do Pontal do Paranapanema à dissensão nos movimentos 
Socioterritoriais Camponeses. Recuperado de http://www.mstemdados.org/sites/default/files/2013\%20jose\%20sobreiro\%20filh o\%20T2.pdf

Stake, R. E. (2005). Case Studies. In N. K. Denzin \& Y. S. Lincoln, The SAGE Handbook of Qualitative Research ( $3^{\circ} \mathrm{ed}$, p. 443-466). Thousand Oaks, London, and New Delhi: SAGE Publications.

Stedile, J. P. (2011). A Questão agrária no Brasil I: O debate tradicional - 1500-1960. (2nd ed). São Paulo: Editora Expressão Popular.

Stedile, J. P., \& Fernandes, B. M. (1996). Brava gente: a trajetória do MST e a luta pela terra no Brasil. São Paulo: Editora Fundação Perseu Abramo.

Tarlau, R. (2015). Not-so-public contention: movement strategies, regimes, and the transformation of public institutions in Brazil. Mobilization, 20(1), 101-121. http://doi.org/10.17813/maiq.20.1.n75648274033x252

Thomaz, F. ([s.d.]). Reflexões acerca do trabalho coletivo camponês. Recuperado de http://www.gepec.ufscar.br/publicacoes/ruralidade/reflexoes-acerca-do-trabalhocoletivo-campones.pdf/view

Thomaz, F. (2010). O modelo socialista de cooperativa de produção Agropecuária (CPA-MST ): contradições e avanços. Estudo de caso da Copava. Recuperado de file://C:/Users/Lucy/Downloads/2010_FernandaThomaz.pdf.

Tragtenberg, M. (1980). Administração, poder e ideologia. São Paulo: Editora Moraes.

Tragtenberg, M. (1987). Uma Prática de Participação: as coletivizações na Espanha (1936/1939). In R. Venosa, Participação e participações: Ensaios sobre autogestão. São Paulo: Editora Babel Cultural.

Williamson, O. E. (1996). Efficiency, power and authority. In J. Groenewegen, Transaction costs economics and beyond (p. 11-42). Boston, Dordrecht \& London: Kluwer Academic Publishers.

Wright, A. L., \& Wolford, W. (2003). To Inherit the Earth: The Landless Movement and the Struggle for a New Brazil. Food First Publications. 
Yin, R. K. (2001). Estudo de caso:- planejamento e métodos $\left(2^{\circ}\right.$ ed). Porto Alegre: Editora Bookman.

Young, D. (2002). The Meaning and role of power in economic theories. In G. M. Hodgson, A modern reader in institutonal and evolutionary economics (p. 48-61). Cheltenham \& Northampton: Edward Elgar Publishing Limited.

Zappellini, M. B., \& Feuerschütte, S. G. (2015). O Uso Da Triangulação Na Pesquisa Científica Brasileira Em Administração. Administração: Ensino e Pesquisa, 16(2), 241. http://doi.org/10.13058/raep.2015.v16n2.238 


\section{APÊNDICE A - ROTEIRO DE ENTREVISTAS SEMIESTRUTURADAS}

1. Qual a sua relação com a cooperativa? Sua história pessoal e a história da cooperativa? Há algum caso ou acontecimento marcante nesta relação?

2. Como se organiza a estrutura do quadro administrativo da cooperativa? Quantos e quais são os níveis hierárquicos existentes na cooperativa? a) Que atividade desempenham? b) Há escolha dos coordenadores? Como ela se dá? É possível destituir alguém escolhido? Como se faz? Já houve alguma vez isso? c) Qual o tempo médio para a troca de coordenadores? E da direção? Há uma concepção de governança entre os produtores, a cooperativas e o ambiente institucional?

3. Há algum mecanismo que previna a perpetuação dos mesmos dirigentes, se isso for necessário? Há algum tipo de atividade de qualificação dos cooperados a fim de promover a sua capacitação, seja na produção, seja na gestão da cooperativa?

4. A terra utilizada no processo produtivo tem algum registro específico?

5. Como se tomam as decisões na cooperativa? Poderia descrever o processo de tomada de decisões. a) Quem participa? b) Como? c) Qual a frequência dessa participação? d) Quanto tempo dura cada tomada de decisão em média? Há algum planejamento do processo de trabalho? Como ele é feito?

6. Ao participar de uma transação com a cooperativa como se dá o pagamento por parte da cooperativa? a) Você identifica critérios para esse modelo de negócios? b) Se sim, a sua opinião esses critérios são válidos (legítimos, justos) ou não? Por que?; se não, você vê ou sugere alguma explicação para essa situação? c) Você acredita que esses critérios encorajem a negociação por meio da cooperação? Por que? d) Isso impõe obstáculos à relação com a cooperativa?

7. Você acredita que a cooperativa deve procurar aumentar o número de cooperados ou acredita que ela deve especializar em um tipo de segmento ou serviço específico?

8. Quando há a entrada de novos cooperados, funcionários ou associados há algum tipo de interação, contato, evento, socialização ou curso de formação, mesmo em um sentido ideológico?

9. A cooperativa contrata funcionários assalariados? Em que áreas (produção, 
administração, técnicos, etc.) e como? Houve participação dos cooperados nessas escolhas? Há algum controle de seu trabalho? Há formas de incentivo a eles? Se sim, de que natureza (monetária, hierárquica, etc.)?

10. Em relação à estratégia de contratação de assalariados, como você analisa esse funcionamento diante do quadro administrativo permanente da cooperativa?

11. Você se lembra de alguma ocasião em que a cooperativa teve seu funcionamento interferido por algum fator externo? Alguma outra organização ou demanda tenha sido feita? E em relação ao trabalho dos produtores especificamente? Houve algum tipo de padrão estabelecido em relação ao trabalho ou ao resultado (norma de higiene ou padrão de qualidade) dos produtos dos cooperados?

12. A cooperativa tem alguma referencia de outra organização ou experiência pela qual ela se orienta ou queira se aproximar? Houve algum contato com representantes dessas?

13. Em relação às condições de financiamento da cooperativa, ela depende de crédito externo para funcionar? a) De que fontes? b) Houve condição para concessão de crédito? Qual? c) Já houve litígio com o agente financeiro (banco, por exemplo)? Por que? Alguma vez a cooperativa mudou alguma decisão interna por conta de pressões externas ligadas ao financiamento? d) A cooperativa depende de algum programa para sobreviver? Se ele acabasse hoje, o que aconteceria com a cooperativa?

14. Qual é a atividade mais rentável da cooperativa em termos monetários? E a sua atividade mais rentável com ela? Existem atividades dedicadas exclusivamente para o autoconsumo? E sua enquanto produtor? Há alguma atividade que seja tanto para autoconsumo, quanto para atender ao mercado?

15. Você já procurou alternativas à cooperativa? Poderia explicar as causas e relatar essa experiência? Houve alguma tentativa de se associar com outros produtores para se prover das vantagens que a cooperativa oferece? Já tentou substituir a cooperativa por outros meios de organização da comercialização da produção?

16. Na sua opinião, quais os principais limites para a sobrevivência do pequeno produtor? E da cooperativa? Quais são as principais vantagens e desvantagens do trabalho coletivo?

17.É possível pensar a cooperativa sem o MST? E o MST sem a cooperativa? Qual seria a consequência que você disso para sua vida e futuro?

18. Como alternativa ao atual quadro você acha que a cooperativa deva se ater à produção? E aos serviços ligados à produção? Ela deve prover serviços de outra ordem, 
dada uma necessidade da sociedade e não mais tão diretamente ligada à produção? Como você sugere que seria a vida no assentamento sem cooperativas? E sem o MST?

\section{APÊNDICE B - QUESTIONÁRIO}

Nome do entrevistado:

Nome do entrevistador:

Nome do assentamento:

Agrovila $n^{\circ}$ : $\quad N^{0}$ do lote:

Município: $\quad$ Estado:

Data da entrevista:

O(a) senhor(a) trabalha diretamente com produção agrícola?

01 Sim 02 Não (encerrar)

Seção 1 - Dados sociodemográficos -

Caracterização do produtor e da unidade familiar

1 - Qual a sua idade: $\operatorname{anos}$

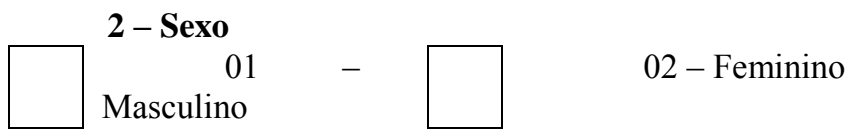

3 - Local de nascimento (cidade):

4 - É descendente de quilombola, imigrante ou indígena?

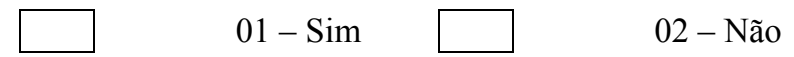

4.1. Se sim, de qual?

5 - Participa de alguma comunidade religiosa?

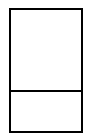

01 - Sim. Qual?

02 - Não (vá para a questão 06)

5.1 - Com que frequência você vai às reuniões de sua comunidade religiosa?
01 - Uma vez por semana
02 - Duas vezes por semana
03 - Mais de duas vezes por semana
04 - De vez em quando

5.2 - Os seus principais amigos são da mesma religião que o(a) sr.(a).?
$01-\mathrm{Sim}$
02 - Não

6 - Em que cidade morava antes de vir para o assentamento?

7 - Há quanto tempo está neste assentamento?

8 - Há quanto tempo trabalha com produção agrícola? 
9 - Participou do processo de ocupação do assentamento?

$1-\operatorname{Sim}$

02 - Não

10 - Qual a experiência anterior que o(a) senhor(a) teve no campo?

\begin{tabular}{|l|}
\hline \\
\hline \\
\hline \\
\hline \\
\hline \\
\hline \\
\hline
\end{tabular}

01 - Produtor por conta própria

02 - Trabalhador temporário

03 - Trabalhador permanente

04 - Meeiro

05 - Caseiro

$06 \quad-\quad$ Outra

qual?

anterior

07 - Não tive experiência

11 - O(a) senhor(a) usa os serviços de alguma Cooperativa (de produção, crédito, consumo, mista) ou de alguma Associação de Produtores?

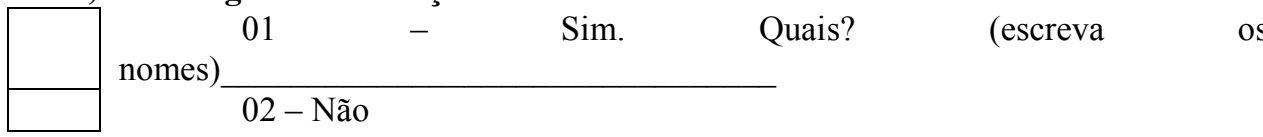

12 - O(a) senhor(a) faz parte de alguma Cooperativa (de produção, crédito, consumo, mista) ou de alguma Associação de Produtores?

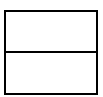

01 - Sim (vá para a questão 12.1).

02 - Não sou cooperado ou associado (vá para a questão 16)

\begin{tabular}{|c|c|r|r|r|}
\hline $\begin{array}{c}\text { 12.1. } \\
\text { Nome da } \\
\text { cooperativa }\end{array}$ & $\begin{array}{r}\text { Tipo } \\
\text { da cooperativa } \\
\text { (produção, } \\
\text { crédito etc.) }\end{array}$ & $\begin{array}{c}\text { A } \\
\text { produção é } \\
\text { realizada } \\
\text { coletivamente } \\
\text { (0) Não } \\
\text { (1) Sim }\end{array}$ & $\begin{array}{r}\text { Qua } \\
\text { la sua } \\
\text { função nessa } \\
\text { cooperativa? }\end{array}$ & $\begin{array}{r}\text { É a } \\
\text { principal da } \\
\text { qual faz parte } \\
\text { (0) Não } \\
\text { (1) Sim }\end{array}$ \\
\hline 1 & & & & \\
\hline 2 & & & & \\
\hline 4 & & & & \\
\hline
\end{tabular}

13 - Nessa Cooperativa/Associação principal, são realizadas coletivamente:
01 - gestão
02 - produção
03 - comercialização

14 - Considerando a Cooperativa/Associação principal, o(a) senhor(a) participa das reuniões da cooperativa/associação?

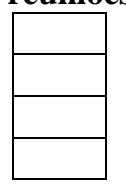

01 - Não frequenta

02 - Participa às vezes

03 - Participa de quase todas

04 - Participa de todas

15 - Vou fazer uma afirmação e gostaria que você me respondesse: "A participação nas reuniões contribui para as minhas decisões de produção e comercialização":

reuniões contribui para as minhas decisões de produção e comercialização":
$01-$ Nunca
contribui


Em que?

16 - Com relação ao(a) senhor(a) e às pessoas que moram com o(a) senhor(a):

\begin{tabular}{|c|c|c|c|c|c|c|c|}
\hline \multirow[t]{2}{*}{ Pessoa } & \multicolumn{2}{|c|}{$\begin{array}{l}\text { Qual o maior nível } \\
\text { de escolaridade } \\
\text { (siga a tabela } \\
\text { abaixo, para } \\
\text { numerar). Escreva } \\
\text { ao lado qual o } \\
\text { curso, no caso de } \\
\text { resposta no nível } \\
05 \text { arionalizante), } \\
\text { profission } \\
07 \text { ou } 09\end{array}$} & \multirow[t]{2}{*}{$\begin{array}{l}\text { Qual é a } \\
\text { ocupação } \\
\text { principal? } \\
\text { (siga a } \\
\text { tabela } \\
\text { abaixo } \\
\text { sobre } \\
\text { ocupação } \\
\text { principal) }\end{array}$} & \multirow[t]{2}{*}{$\begin{array}{l}\begin{array}{l}\text { Essa } \\
\text { ocupação } \\
\text { principal é: } \\
\qquad(1) \\
\text { Dentro da } \\
\text { propriedade } \\
\quad(2) \\
\text { Fora da } \\
\text { propriedade }\end{array}\end{array}$} & \multirow[t]{2}{*}{$\begin{array}{l}\text { A atividade } \\
\text { exercida é: } \\
\text { (1) } \\
\text { Remunerada } \\
\text { (2) Não } \\
\text { remunerada }\end{array}$} & \multirow[t]{2}{*}{$\begin{array}{l}\text { Tem } \\
\text { outra } \\
\text { renda } \\
\text { além da } \\
\text { atividade } \\
\text { agrícola? } \\
\text { (Siga a } \\
\text { tabela } \\
\text { abaixo } \\
\text { sobre } \\
\text { outras } \\
\text { rendas) }\end{array}$} & \multirow[t]{2}{*}{$\begin{array}{l}\text { Da renda da } \\
\text { família, qual } \\
\text { a } \\
\text { contribuição } \\
\text { da atividade } \\
\text { agrícola (por } \\
\text { exemplo: } \\
\text { contribui } \\
\text { com metade, } \\
\text { com } 1 / 4 \text { etc.). }\end{array}$} \\
\hline & Nível & Curso & & & & & \\
\hline \multicolumn{8}{|l|}{$\begin{array}{c}1 . \\
\text { Entrevistado }\end{array}$} \\
\hline 2 & & & & & & & \\
\hline 3. & & & & & & & \\
\hline 4. & & & & & & & \\
\hline 5. & & & & & & & \\
\hline 6. & & & & & & & \\
\hline 7. & & & & & & & \\
\hline 8. & & & & & & & \\
\hline 9. & & & & & & & \\
\hline 10. & & & & & & & \\
\hline
\end{tabular}

Tabela sobre ocupação principal

\begin{tabular}{|c|c|}
\hline 1 & Agropecuária (produtor) \\
\hline 2 & $\begin{array}{c}\text { Ocupações especializadas agropecuária } \\
\text { (tratorista, motorista etc.) }\end{array}$ \\
\hline 3 & Indústria, construção civil \\
\hline 4 & Diarista \\
\hline 5 & Comércio e serviços em geral \\
\hline 6 & Outra, qual? \\
\hline
\end{tabular}

Tabela sobre outras rendas 


\begin{tabular}{|l|l|}
\hline 02 & Aposentadoria \\
\hline 03 & Bolsa Família \\
\hline 04 & Outra, qual? \\
\hline
\end{tabular}

Tabela de nível de escolaridade

\begin{tabular}{|c|c|}
\hline 1 & Nunca estudou \\
\hline 2 & Ensino Fundamental incompleto \\
\hline 3 & Ensino Fundamental completo \\
\hline 4 & Ensino Médio incompleto \\
\hline 5 & $\begin{array}{l}\text { Ensino Médio completo. } \\
\text { Se profissionalizante, qual curso? }\end{array}$ \\
\hline & Ensino Superior incompleto \\
\hline 7 & Ensino Superior completo. Qual curso? \\
\hline 8 & Pós-graduação incompleto \\
\hline 9 & Pós-graduação completo. Qual curso? \\
\hline 0 & Outro: ex curso de curta duração \\
\hline
\end{tabular}

Tabela sobre o curso

\begin{tabular}{|l|l|}
\hline 1 & Direito \\
\hline 2 & Agronomia \\
\hline 3 & Pedagogia \\
\hline 4 & Administração \\
\hline 5 & Letras \\
\hline 6 & qual? \\
\hline
\end{tabular}

17 - Vou citar algumas frases sobre Educação e gostaria que o(a) senhor(a) me dissesse qual o grau de concordância que tem com cada uma delas. Essas afirmações foram elaboradas para que possa saber o que o(a) sr(a) pensa sobre o assunto.

\begin{tabular}{|c|c|c|c|c|c|}
\hline & $\begin{array}{l}\text { Discordo } \\
\text { totalmente }\end{array}$ & Discordo & \begin{tabular}{|l|} 
Não \\
concordo/nem \\
discordo \\
\end{tabular} & Concordo & $\begin{array}{l}\text { Concordo } \\
\text { totalmente }\end{array}$ \\
\hline $\begin{array}{l}\text { 17.1. A formação em } \\
\text { escolas do campo é mais } \\
\text { adequada para quem vai } \\
\text { trabalhar no campo. }\end{array}$ & 01 & 02 & 03 & 04 & 05 \\
\hline
\end{tabular}




\begin{tabular}{|c|c|c|c|c|c|}
\hline $\begin{array}{l}\text { 17.2. Meu rendimento } \\
\text { financeiro melhorou após } \\
\text { eu ou alguém de minha } \\
\text { família ter concluído a } \\
\text { faculdade/universidade. }\end{array}$ & 01 & 02 & 03 & 04 & 05 \\
\hline $\begin{array}{l}\text { 17.3. Gostaria de ter feito } \\
\text { uma } \\
\text { faculdade/universidade } \\
\text { para poder trabalhar no } \\
\text { campo. }\end{array}$ & 01 & 02 & 03 & 04 & 05 \\
\hline $\begin{array}{l}\text { 17.4. Quem faz faculdade } \\
\text { deve sair do campo para } \\
\text { trabalhar na cidade. }\end{array}$ & 01 & 02 & 03 & 04 & 05 \\
\hline $\begin{array}{l}\text { 17.5. Pude aplicar o que } \\
\text { foi estudado por mim ou } \\
\text { por alguém da minha } \\
\text { família na escola ou } \\
\text { faculdade/universidade } \\
\text { em minha atividade } \\
\text { produtiva. }\end{array}$ & 01 & 02 & 03 & 04 & 05 \\
\hline $\begin{array}{l}\text { 17.6. Os filhos devem } \\
\text { estudar em escolas ou } \\
\text { faculdades/universidades } \\
\text { para que melhore a } \\
\text { minha produção no } \\
\text { campo. }\end{array}$ & 01 & 02 & 03 & 04 & 05 \\
\hline $\begin{array}{l}\text { 17.7. A educação na } \\
\text { faculdade/universidade } \\
\text { traz melhorias para a } \\
\text { produção no campo. }\end{array}$ & 01 & 02 & 03 & 04 & 05 \\
\hline $\begin{array}{l}\text { 17.8. Deveria haver } \\
\text { faculdade/universidade } \\
\text { dentro do assentamento } \\
\text { para aprender algo que } \\
\text { pudesse ser aplicado no } \\
\text { campo. }\end{array}$ & 01 & 02 & 03 & 04 & 05 \\
\hline $\begin{array}{l}\text { 17.9. É preciso formação } \\
\text { em } \\
\text { faculdade/universidade } \\
\text { para poder trabalhar em } \\
\text { produção rural. }\end{array}$ & 01 & 02 & 03 & 04 & 05 \\
\hline $\begin{array}{l}\text { 17.10. Deveria haver um } \\
\text { programa do governo } \\
\text { para enviar as pessoas } \\
\text { que trabalham no campo } \\
\text { para as } \\
\text { faculdades/universidades. }\end{array}$ & 01 & 02 & 03 & 04 & 05 \\
\hline
\end{tabular}

Seção 2 - Créditos e subsídios para a produção

18 - O(A) senhor(a) fez empréstimos para a produção agrícola?

$01 \quad 02$ - Não (vá para a questão 23)

19 - Em caso afirmativo, quando (em que ano)? 
20 - Para quê?

Investimento

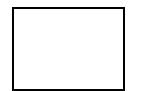

$02-$ Custeio

21 - Qual o valor do último empréstimo que fez?

Investimento: (ano: ) e Custeio:

(ano:

22 - O empréstimo está inserido dentro de algum programa governamental?

(Pronaf ou outro)

$$
01 \text { - Sim. Qual? }
$$

02 - Não

Seção 3 - Uso da Terra

23 - Em relação ao uso da terra, qual a área sob sua gestão no ano safra 2014/2015?

(verificar qual a unidade de medida utilizada pelo produtor:

alqueire (especificar - paulista, mineiro, goiano etc.), hectares).

\begin{tabular}{|l|l|}
\hline Área sob sua gestão & Medida: \\
\hline Total da área sob sua gestão \\
$\mathrm{A}$ - Área própria no quintal \\
$\mathrm{B}$ - Área própria individual \\
$\mathrm{C}$ - Área na produção coletiva \\
$\mathrm{D}$ - Área de terceiro arrendada pelo(a) senhor(a) [ $]$
\end{tabular}

24 - Você arrenda ou empresta parte do seu lote a terceiros?

01 - Sim, arrendo. Por que?

01 - Sim, empresto. Por que?

02 - Não (vá para a questão 26)

25 - Em caso afirmativo, qual a medida?

(especificar se alqueire - qual e se hectare etc.)

$\mathbf{2 5}$ - Em caso afirmativo, qual a medida?

(especificar se alqueire - qual e se hectare etc.)

Seção 4 - Caracterização da atividade

26 - Quanto à sua produção (própria ou coletiva), considerando a safra 2014/2015: 


\begin{tabular}{|c|c|c|c|c|c|c|}
\hline \multirow[t]{2}{*}{$\begin{array}{l}\text { Você produz... } \\
\text { (assinale os } \\
\text { produtos que o } \\
\text { entrevistado } \\
\text { informa } \\
\text { produzir) }\end{array}$} & \multicolumn{2}{|c|}{$\begin{array}{l}\text { Qual a quantidade } \\
\text { produzida na safra } \\
2014 / 2015 ? \\
\text { (especificar a unidade - } \\
\text { Quilos / toneladas / } \\
\text { caixas / litro) }\end{array}$} & \multicolumn{2}{|c|}{$\begin{array}{l}\text { Percentual } \\
\text { produzido } \\
\text { individual e } \\
\text { coletivamente }^{28}\end{array}$} & \multicolumn{2}{|c|}{$\begin{array}{l}\text { Quantidade vendida } \\
\text { (especificar unidade - } \\
\text { quilos / toneladas / caixas / } \\
\text { litros) }\end{array}$} \\
\hline & Individual & Coletivo & Individual & Coletivo & Individual. & Coletivo \\
\hline \multicolumn{7}{|l|}{01 Feijão } \\
\hline \multicolumn{7}{|l|}{02 Soja } \\
\hline \multicolumn{7}{|l|}{03 Milho } \\
\hline \multicolumn{7}{|l|}{04 Trigo } \\
\hline \multicolumn{7}{|l|}{05 Verduras } \\
\hline \multicolumn{7}{|l|}{ 06 Leite } \\
\hline \multicolumn{7}{|l|}{ 07Cachaça } \\
\hline \multirow{2}{*}{\multicolumn{7}{|c|}{08 Ovos }} \\
\hline \multirow{2}{*}{\multicolumn{7}{|c|}{$\begin{array}{l}\text { 09 Carne } \\
10 \text { Banana }\end{array}$}} \\
\hline & & & & & & \\
\hline \multicolumn{7}{|l|}{$\begin{array}{l}11 \text { Outro. } \\
\text { Qual? }\end{array}$} \\
\hline & & & & & & \\
\hline & & & & & & \\
\hline & & & & & & \\
\hline & & & & & & \\
\hline
\end{tabular}

\section{(Continuação da tabela acima)}

\begin{tabular}{|c|c|c|}
\hline \multirow{2}{*}{$\begin{array}{l}\text { Esse produto é } \\
\text { produzido em } \\
\text { seu quintal para } \\
\text { seu consumo? } \\
\text { (0)Não } \\
\text { (1) Sim }\end{array}$} & \multirow[t]{2}{*}{$\begin{array}{l}\text { Esse produto também é } \\
\text { para venda? } \\
\text { (0) Não } \\
\text { (1) } \mathrm{Sim}\end{array}$} & $\begin{array}{l}\text { Esse produto é seu } \\
\text { principal produto de } \\
\text { venda em termos de } \\
\text { quantidade } \\
\text { (0) Não } \\
\text { (1) Sim }\end{array}$ \\
\hline & & \\
\hline & & \\
\hline & & \\
\hline & & \\
\hline & & \\
\hline & & \\
\hline
\end{tabular}

${ }^{28}$ Perguntar essa questão caso o produtor não saiba especificar a quantidade. 
27 - A sua principal preocupação ao produzir é:

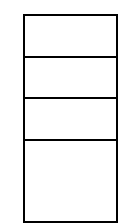

01 - aumentar a sua produção

02 - o prazer de trabalhar com agricultura

03 - participar da comunidade produtiva

04 - investir na educação dos filhos

28 - Uso de mão de obra na produção agropecuária no ano safra 2014/2015

\begin{tabular}{|c|c|}
\hline \multicolumn{2}{|c|}{ Morador } \\
\hline $\begin{array}{c}\text { Grau de parentesco } \\
\text { (membro da família, } \\
\text { outros...) }\end{array}$ & $\begin{array}{c}\text { Horas de trabalho } \\
\text { por semana }\end{array}$ \\
\hline 1. Entrevistado & \\
\hline 2. & \\
\hline 3. & \\
\hline 4. & \\
\hline
\end{tabular}

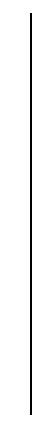

\begin{tabular}{|c|c|c|}
\hline \multicolumn{3}{|c|}{ Não Morador (fora do lote): plantio, capina, roçada, colheita, etc } \\
\hline Trabalhadores & $\begin{array}{l}\text { Horas de trabalho anual (se não } \\
\text { souber pode dia/semana, mas } \\
\text { veja se é o ano todo ou só alguns } \\
\text { meses) }\end{array}$ & $\begin{array}{l}\text { Paga em: } \\
\text { (1) } \\
\text { dinheiro } \\
\text { (2) espécie } \\
\text { (3) favor }\end{array}$ \\
\hline 1 & & \\
\hline 2 & & \\
\hline 3 & & \\
\hline 4 & & \\
\hline Total gasto (ano) & & \\
\hline
\end{tabular}

28.1 Você participa de mutirão?

01 - Não, (vá para 29)

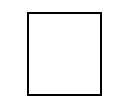

02 - Construção de casa de vizinho

03 - Construção armazém /outro na cooperativa

04. Para Plantar

05. Para colher

28.2 Qual foi a última vez que participou?

Por que? (participa / ou não):

28.3 Existe uma regra (não escrita) na prática de mutirão?

28.4 Se você cooperava e não coopera mais, diga porque: 
Consumo de fertilizantes na produção agropecuária no ano safra 2014/2015:

29 - Utiliza adubos?

\begin{tabular}{|c|c|c|}
\hline \multirow{2}{*}{$\begin{array}{c}\text { Sim } \\
\text { Sim }\end{array}$} & \multicolumn{2}{|c}{$02-$ Não (vá para a questão 30 ) } \\
\hline $\begin{array}{c}\text { Uso de } \\
\text { adubos }\end{array}$ & $\begin{array}{c}\text { Quantidade utilizada } \\
\text { na safra 2014/2015 }\end{array}$ & $\begin{array}{c}\text { Valor gasto na } \\
\text { safra 2014/2015 }\end{array}$ \\
\hline Químico & & \\
\hline Orgânico & & \\
\hline
\end{tabular}

30 - Utiliza agrotóxico (veneno)?

$\begin{array}{ll}0 & 01 \\ -S i m & 02\end{array}$

31 - Em caso afirmativo: Valor gasto na safra 2014/2015:

Quantidade utilizada na safra 2014/2015:

Em relação ao seu maquinário/implementos agrícolas (arado, grade, semeadeira, colheitadeira):

32 - Você utiliza trator na produção agrícola?

$-\operatorname{Sim}$

01

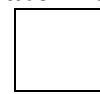

02 - Não (vá para a questão 33)

\begin{tabular}{|c|l|l|l|}
\hline $\begin{array}{l}\text { de máquinasán } \\
\text { implementos }\end{array}$ & $\begin{array}{l}\text { (0) individual } \\
\text { (1) coletivo } \\
\text { (2) empréstimo de terceiros }\end{array}$ & $\begin{array}{l}\text { Anos } \\
\text { de } \\
\text { uso }\end{array}$ & $\begin{array}{l}\text { Horas de } \\
\text { utilização anual }\end{array}$ \\
\hline Tratores & & & \\
\hline 1. & & & \\
\hline 2. & & & \\
\hline 3. & & & \\
\hline 4. & & & \\
\hline 5. & & & \\
\hline
\end{tabular}

33 - Detalhe, por favor, os implementos utilizados na produção agrícola.

\begin{tabular}{|c|l|c|}
\hline $\begin{array}{l}\text { Implementos } \\
\text { (arado, } \begin{array}{l}\text { (0) individual } \\
\text { semeadeira, } \\
\text { colheitadeira etc): }\end{array}\end{array}$ & $\begin{array}{l}\text { (1) coletivo } \\
\text { (2) empréstimo de } \\
\text { terceiros }\end{array}$ & $\begin{array}{c}\text { Horas de utilização } \\
\text { anual }\end{array}$ \\
\hline 1. & & \\
\hline 2. & & \\
\hline 3. & & \\
\hline 4. & & \\
\hline 5. & & \\
\hline
\end{tabular}


34 - Quanto aos seus custos:

\begin{tabular}{|c|c|}
\hline $\begin{array}{l}\text { Gasto total na safra 2014- } \\
2015\end{array}$ & Gasto total (RS) \\
\hline 1. Óleo Diesel (1) & \\
\hline 2. Energia elétrica $(\mathrm{kW})$ & \\
\hline 3. Água para irrigação (1) & \\
\hline 4. Outros (especificar) & \\
\hline
\end{tabular}

35 - O senhor(a) empresta para seu vizinho implementos/maquinário agrícolas?

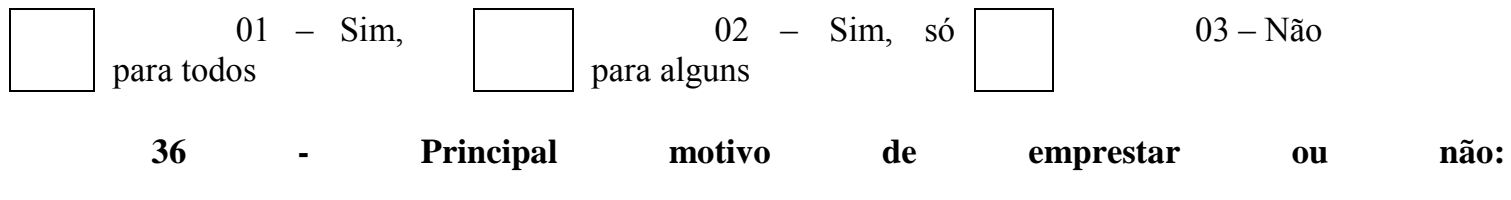

36.1 O senhor(a) troca informação da sua produção?

(pode preencher mais de uma opção e colocar em ordem de importância)

$01-\mathrm{Sim}$, com vizinhos

02 - Sim, com compradores

03 - Sim, com amigos da igreja

04 - Sim, com parente

05 - Não divido informação (vá para a questão 36.3)

36.2 Se sim, que tipo de informação?

(sobre técnica de produção, preço, sobre o que plantar, para quem vender)

36.3 Os demais produtores dividem informação de produção/comércio com você? 